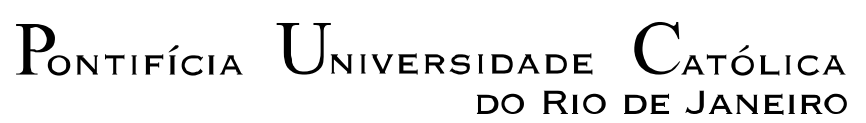

DO RIO DE JANEIRO

Marcio Amorim Lazaroni

Camadas de cobertura de fibrobarro:

Técnicas de produção em laboratório e em diferentes contextos comunitários

Dissertação de Mestrado

Dissertação apresentada ao Programa de PósGraduação em Design da PUC-Rio como requisito parcial para obtenção do grau de Mestre em Design do Departamento de Artes \& Design da PUC-Rio.

Orientador: Prof. José Luiz Mendes Ripper 


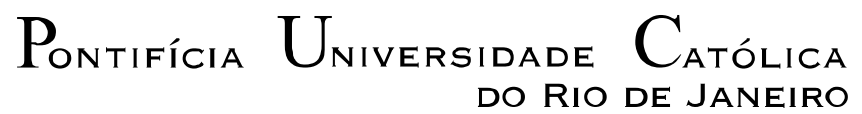

Marcio Amorim Lazaroni

\section{CAMADAS DE COBERTURA DE FIBROBARRO: \\ Técnicas de produção em laboratório e em diferentes \\ contextos comunitários}

Dissertação apresentada ao Programa de PósGraduação em Design da PUC-Rio como requisito parcial para obtenção do grau de Mestre em Design. Aprovada pela Comissão Examinadora abaixo assinada.

Prof. José Luiz Mendes Ripper

Orientador

Departamento de Artes \& Design - PUC-Rio

Prof. Fernando Betim Paes Leme Departamento de Artes \& Design - PUC-Rio

Prof. Luis Eustáqui Moreira Universidade de Minas Gerais - UFMG

Profa. Denise Berruezo Portinari Coordenadora Setorial do Ce-ntro de Teologia e Ciências Humanas - PUC-Rio

Rio de Janeiro, 12 de Abril de 2013 
Todos os direitos reservados. É proibida a reprodução total ou parcial do trabalho sem autorização da universidade, do autor e do orientador.

\section{Marcio Amorim Lazaroni}

Graduou-se em Design, com habilitação em Projeto de Produto, pelo Departamento de Artes \& Design da PUCRio, em 2002. Cursou Licenciatura plena em Educação Artística pelo Instituto Metodista Bennett em 2009. Desde 1997 trabalha com educação em acampamentos educativos e atividades extracurriculares. A partir de 2001 começou a trabalhar com projetos de objetos arquitetônicos com materiais biocompatíveis. No ano de 2010 começou a lecionar aulas de artes em escolas do ensino fundamental 1 até o ensino médio.

Ficha Catalográfica

Lazaroni, Marcio Amorim
Camadas de cobertura de
fibrobarro: técnicas de produção em
laboratório e em diferentes contextos
comunitários / Marcio Amorim Lazaroni;
orientador : José Luiz Mendes Ripper. -
2013 .
147 f. ; il. (color) ; $30 \mathrm{~cm}$
Dissertação (mestrado) - Pontifícia
Universidade Católica do Rio de Janeiro,
Departamento de Artes \& Design, 2013.
Inclui bibliografia
Artes e design - Teses. 2. Terra
crua. 3. Taipa. 4. Pau-a-pique. 5.Fibrobarro
6. Compósito. 7. Cal hidratada. 8.LILD 9.
Bioarquitetura. I. Ripper, José Luiz Mendes
II. Pontifícia Universidade Católica do Rio
de Janeiro. Departamento de Artes \&
Design III. Título.

CDD: 700 
À Ana Luiza, por encher de luz meu coração.

À Paula, por me impulsionar a crescer cada vez mais. 


\section{Agradecimentos}

Ao meu orientador, José Luis Mendes Ripper por todo suporte dado.

A PUC-Rio e a Vice-Reitoria Acadêmica do curso pela oportunidade de realizar a pesquisa

A todos os mais de 100 voluntários que participaram das atividades gerando aprendizado e trabalho em equipe. Sem eles este trabalho não seria possível.

Ao professor Luis Vicente Barros pelo suporte em várias etapas do processo de desenvolvimento

Aos pesquisadores e voluntários do LILD com destaque para Mariano, Daniel Malaguti, Tiago, João Victor e tantos outros que passaram pelo Laboratório.

À Paula e Ana Luiza por todo amor.

Aos meus pais por me ensinarem o valor da educação

Aos meus professores durante estes dois anos que muito contribuíram para a reflexão e o aprendizado.

Aos parceiros que deram todo o suporte realizando as tarefas invisíveis.

Ao barro, as fibras naturais e todos os sistemas da natureza, verdadeiros professores desta dissertação. 


\section{Resumo}

Lazaroni, Marcio Amorim; Ripper, José Luis Mendes. Camadas e cobertura em fibrobarro: técnicas de produção em laboratório e em diferentes contextos comunitários. Rio de Janeiro, 2013. 147p. Dissertação de Mestrado - Departamento de Artes \& Design. Pontifícia Universidade Católica do Rio de Janeiro.

Esta dissertação mostra estudos de aplicações e revestimento do fibrobarro em diferentes contextos dentro do Estado do Rio de Janeiro. Através da pesquisa efetuada dentro e fora do Laboratório de Investigação em Livre Desenho (LILD) foram desenvolvidas possibilidades de aplicação do fibrobarro aproveitando os recursos disponíveis. A pesquisa relata alguns materiais já utilizados para a cobertura de construções em materiais biocompatíveis. Durante o processo da pesquisa avergou-se possibilidades para a fabricação de compósitos, principalmente na abrangência de possíveis fibras quando o fibrobarro não for utilizado como principal elemento estrutural. O revestimento também é pesquisado com destaque para o uso da pasta de cal hidratada. Ao efetuar a pesquisa de campo em paralelo aos estudos em laboratório foi possível perceber a importância do gestual no ato de fazer artesanalmente objetos que buscam ser perenes respeitando o ambiente local e considerando-se o seu descarte. Durante o processo de pesquisa também foi observado a construção dos objetos arquitetônicos com voluntários de diferentes contextos socioeconômicos o que possibilitou perceber a importância dessa diversidade para atingir a "convivencialidade" (Illich, 1976) e como uma metodologia atenta e sensível, fundamental para desenvolvermos uma verdadeira ciência de construção respeitando as características sociais e ambientais de cada região.

\section{Palavras-chave}

Terra crua; taipa; pau-a-pique; fibrobarro; compósito; cal hidratada; LILD; Bioarquitetura. 


\section{Abstract}

Lazaroni, Marcio Amorim; Ripper, José Luis Mendes (Advisor). Layers and coverages using fibersoil - Production techniques in the laboratory and at different community contexts. Rio de Janeiro, 2013. 147p. MSc Dissertation - Departamento de Artes \& Design. Pontifícia Universidade Católica do Rio de Janeiro.

This master thesis studies shows applications and finishes of fibersoil in different contexts inside the State of Rio de Janeiro. Through the work done inside and outside the Laboratory of Research in Free Drawing (LILD) investigate possible applications of fibersoil using the resources available. At the beginning of the work trace is already some materials used for covering buildings made with biocompatible materials inside and outside the LILD. During the process of research we discovered some possibilities for the manufacture of composites, especially in the range of possible using of fibers when it is not used as the main structural element. We also researched some possibilities for finishing construction of fibrosoil more careful in the use of hydrated lime paste. When we make the field research in parallel with laboratory studies we realized the importance of the gestures in the act of making objects that seek to be a evergreen respecting the local environment and considering your disposal. During the research process we also observed the construction of architectural objects with volunteers from different socioeconomic contexts which enabled us to realize the importance of gesture and an attentive and sensitive methodology is important to develop a true science of construction respecting the social and environmental characteristics of each region.

\section{Keywords}

Raw land; mud; wattle-and-daub; fibrosoil; composite; hydrated lime; bioarchitecture; LILD. 


\section{Sumário}

$\begin{array}{lr}\text { Agradecimentos } & 5\end{array}$

$\begin{array}{ll}\text { Resumo } & 6\end{array}$

$\begin{array}{ll}\text { Palavras-chave } & 6\end{array}$

$\begin{array}{ll}\text { Abstract } & 7\end{array}$

$\begin{array}{ll}\text { Keywords } & 7\end{array}$

1 Introdução 18

1.1. Questões norteadoras 18

$\begin{array}{ll}\text { 1.2. Objeto da pesquisa } & 19\end{array}$

1.3. Objetivo Geral e objetivos específicos. 20

$\begin{array}{ll}\text { 1.4. Justificativa e relevância da pesquisa } & 21\end{array}$

1.5. Métodos e Técnicas de Pesquisa 22

1.6. Divisão dos capítulos 23

1.7. Motivação Pessoal 24

2. Conceitos da pesquisa 25

2.1. Crise do modelo convencional de construção 25

2.2. Construções com materiais biocompatíveis como fonte de transformação social 28

2.3. Desafios para as construções com materiais biocompatíveis 30

3 Revisão bibliográfica dos métodos e materiais para a confecção de camadas de cobertura 33

3.1. Materiais de origem mineral 33

3.1.1. Betume 33

3.1.2. Terra crua 34

3.1.3. Cimento 35

3.1.4. Cal hidratada 36

3.2. Materiais de origem vegetal 38

3.2.1. Mucelagem de cactos 38 
3.2.2. Óleos 39

3.2.3. Mandioca e trigo 40

3.2.4. Casca de arroz fermentada $\quad 40$

3.3. Materiais de origem animal 41

3.4. Ferramentas e gestos no processo de construção 42

3.5. Alguns experimentos do LILD 44

3.5.1. Fibras experimentadas 45

3.5.2. Camadas de cobertura para proteção 46

3.6. Inferências 46

4 Experimentos feitos no LILD 48

4.1. Corpos de prova de terra crua: um teste de fibras e proporções 48

4.1.1. Testes de aplicação sobre tecidos 49

4.1.2. Esferas de fibrobarro 55

4.2. Fibras naturais 56

4.3. Películas de capeamento 63

4.3.1. Camadas grossas 63

4.3.2. Películas de capeamento 68

4.4. Testes de misturas $\quad 70$

4.5. Experimentos de cal hidratada de diferentes tipos 73

4.6. Testes de permeabilidade à água estática 76

4.6.1. Teste de imersão na água $\quad 80$

5 Aplicação da Pesquisa - Estudos de Caso 88

5.1. Parabolóide de dupla curvatura 88

5.1.1. Camada feita por tecido de juta e barro 89

5.1.2. Compósitos de fibras e barro sobre o parabolóide 93

5.2. Horta Orgânica do Jardim Anil 96

$\begin{array}{lr}\text { 5.3. Túnel expositor } & 107\end{array}$

$\begin{array}{ll}\text { 5.3.1. Construção do túnel } & 108\end{array}$

5.3.2. Uso da Pastacal como proteção do túnel. 113

$\begin{array}{ll}\text { 5.3.3. Desconstrução } & 115\end{array}$

5.4. Demonstração da técnica do fibrobarro na Rio+20 117

5.5. Experimentações na Fazenda Faraó - Cachoeiras de Macacu (RJ) 119

5.5.1. Módulos icosaédricos

$\begin{array}{ll}\text { 5.5.2. Telhados de Fibrobarro } & 126\end{array}$

$\begin{array}{ll}\text { 5.5.3. Espiral treliça } & 133\end{array}$ 
6 Principais resultados

7 Referências Bibliográficas 


\section{Lista de figuras}

Figura 1 - Solar Grandjean de Montigny - PUC-Rio. 2008. Construção de terra crua de 1830. Fonte:

http://www.pucrio.br/sobrepuc/depto/solar/index.html. 27

Figura 2 - Núcleo ainda úmido apesar do exterior já estar seco.

Figura 3 - Esfera maciça de pastacal seccionada depois de um mês secando

Figura 4 - Mucilagem com 2 dias de fermentação. Ainda é possível ver os pedaços de cactos na superfície.

Figura 5 - Após 10 dias de fermentação as amostras foram para o fundo do balde 39

Figura 6 - Mistura de mucilagem de cactus com barro sendo levantado. 39

Figura 7 - Moradores da cidade cobrindo as paredes da mesquita de barro com casca de arroz fermentado. Fonte: (Allen, 2011)

Figura 8- LILD - PUC-Rio. Em abril de 2011. Parede externa do LILD.

Treliça de bambu coberta por argila e fibras e tecidos de fibras naturais.

Figura 9 -. Tecido exposto contra a luz. 50

Figura 10 - Tecido de juta, depois da aplicação de solo, sendo retirado da mesa.

Figura 11 - Aplicação de solo sobre tecido em molde curvo..............................51

Figura 12 - Dedos pressionando o tecido para fixar no barro ............................52

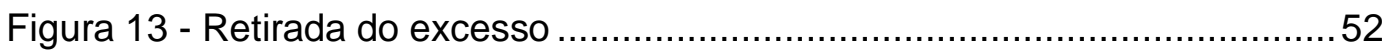

Figura 14 - Feltro exposto contraluz............................................................... 52

Figura 15 - Compósitos de juta-barro e de feltro barro colocadas sobre

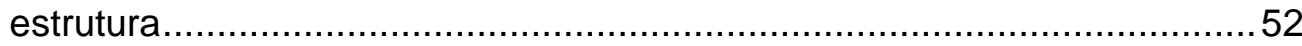

Figura 16 - Aplicação sobre tecido com e sem fibras adicionais. .......................53

Figura 17 - Tecidos de fibras naturais e de feltro (verde) esticados em molduras.

Figura 18- Tecido de juta sobreposto. 53

Figura 19 - Tecido de algodão sobreposto. A segunda camada chega a desaparecer visualmente. 53

Figura 20 - Usando o rolete .54

Figura 21 - Pressionando as camadas com as mãos 
Figura 22 - Casca laminada de tecido de algodão e barro

Figura 23 - Rolo de pvc e batentes de madeira ajudaram a formar chapas

de espessura controlada.

Figura 24 - Junção de placas sobre molde de vinil para a construção de esferas ocas.

Figura 25 - Esferas e placas curvas com diferentes tipos de fibras e quantidades. A esfera sem fibras partiu-se completa-mente deixando o molde a mostra.

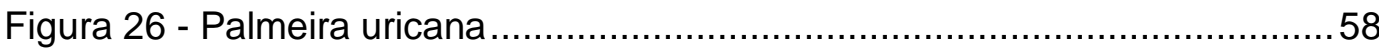

Figura 27 - Experimento prático para determinação do volume de fibras...........59

Figura 28 - Compósito de fibras de bambu e barro. ........................................6

Figura 29 - Planta Colônia (Alpinia speciosa)................................................61

Figura 30 - Detalhe da planta Colônia.........................................................61 61

Figura 31 - Fibras resultantes da ação de martelar ..........................................61 61

Figura 32 - Processamento da fibra utilizando um martelo.............................61 61

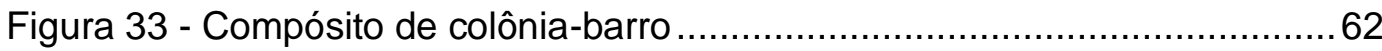

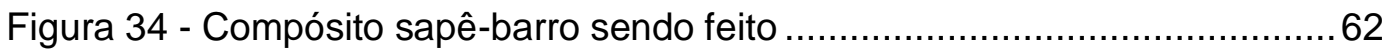

Figura 35 - Depois de cortar o compósito, foi perceptível o que barro com a vibração 62

Figura 36 - Detalhe da laminação entre a camada de acoplamento e uma

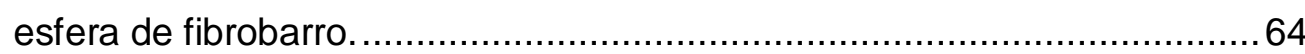

Figura 37 - Camada de capeamento grossa rachada.....................................64

Figura 38- camada de cal hidratada sem fibras. Superfície apresenta diversas fissuras.

Figura 39 - Cobertura de cal hidratada com fibras de grama. Sem fissuras aparentes

Figura 40 - Ranhuras feitas na superfície para aumentarmos a área de contato.

Figura 41 - Hidratação da superfície antes da aplicação da camada. O mesmo procedimento foi feito após a aplicação da camada de cobertura.

Figura 42 - Alisando o compósito para dar um acabamento mais homogêneo.

Figura 43 - Feltragem do compósito cal-fibras de grama. 67

Figura $44-4$ testes de capeamento com solo e cal. Os quadrantes superiores foram hidratados e os quadrantes da direita foram misturados com fibras. 
Figura 45 - Duas esferas ocas. A da direita recebeu uma camada de

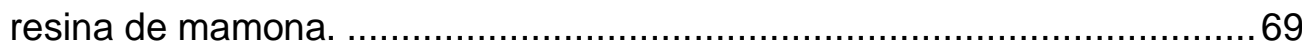

Figura 46 - Aplicação de PVA usando pincel................................................69

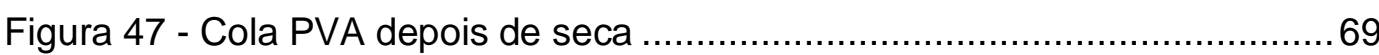

Figura 48 - Camada fina de polvilho azedo depois de algumas semanas. .........70

Figura 49 - Esferas cobertas com polvilho azedo. A da esquerda foi misturada com terra. $\mathrm{Na}$ da direita foi aplicado uma película fina. 70

Figura 50 - Quatro combinações de aplicação de camada de cobertura usando pastacal, fibras e goma de mandioca 71

Figura 51 - Cal hidratada misturada com outros protetores usados em

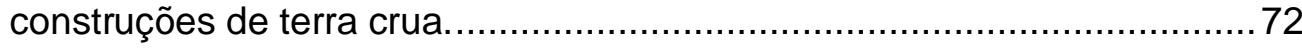

Figura 52 - Depois de duas semanas o composto ficou quebradiço ..................73

Figura 53 - Cal-caseína sendo produzida .................................................... 73

Figura 54 - Delaminação da segunda camada de cal hidratada ..........................75

Figura 55 - Placas cobertas com diferentes tipos de cal hidratada. A placa

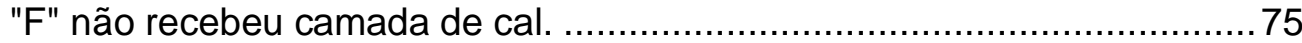

Figura 56 - Aplicação de camada com espátula............................................... 76

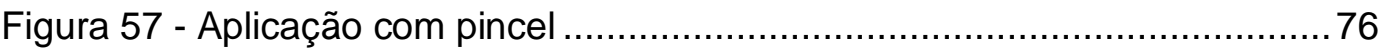

Figura 58 - Trincas surgidas nas amostras C, D e E ....................................... 76

Figura 59 - Pequenas fissuras nas amostras A e B.........................................76

Figura 60 - Teste sobre vidro do retentor de água. ......................................... 77

Figura 61 - cobertura de resina de mamona. Ambas não aparentaram

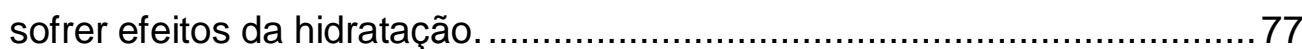

Figura 62 - Cobertura de PVA sendo testada com água ................................77

Figura 63 - Lentamente a água era absorvida e "distribuída" pela

superfície. Internamente não notamos diferença....................................78

Figura 64 - Cal hidratada logo no início parecia não absorver a água. ...............78

Figura 65 - Amostra de cal com barro misturados sobre placa curva. ................78

Figura 66 - Placa com película de cal feita 2 dias antes do experimento............79

Figura 67 - Placa de argila pura que cedeu em poucos minutos. ......................79

Figura 68- Depois de ceder, foi percebido que a película de cobertura

permitia a passagem da água para a parte interna.

Figura 69 - Teste sobre esfera com película de mucilagem de cactos palma.

Figura 70 - Esferas testadas perfiladas 80

Figura 71- esfera coberta de cola pva rompeu com uma hora de experimento. 
Figura 72 - Esfera 5 com manchas de absorção de umidade por dentro e

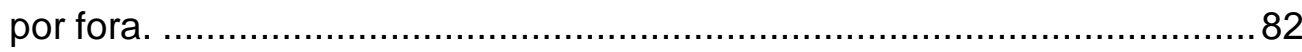

Figura 73 - Esfera 4 com 30 minutos de experiência ..................................... 82

Figura 74 - Esfera com 60 minutos de experiência ......................................... 82

Figura 75 - Detalhe do abalo estrutural da esfera 4 ...................................... 83

Figura 76 - Esfera 1 com 30 minutos de experimento ....................................... 84

Figura 77 - Esfera 1 com 14 minutos de experimento ....................................... 84

Figura 78 - Esfera 2 apresentando fissuras ................................................ 84

Figura 79 - Água brotando da base da esfera 1. A foto foi equalizada nas

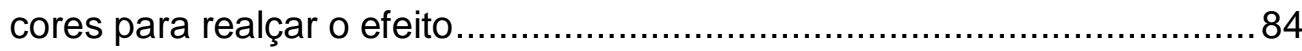

Figura 80 - Sequencia de crescimento da mancha de água............................. 85

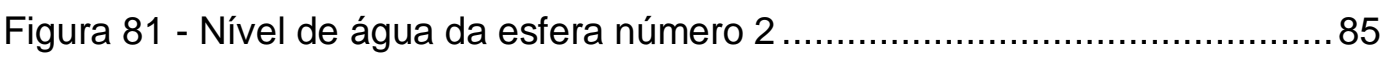

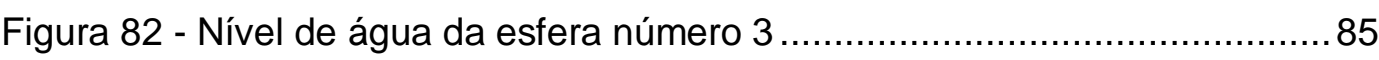

Figura 83 - Esfera 4 já havia se rompido quando a esfera 3 começou a

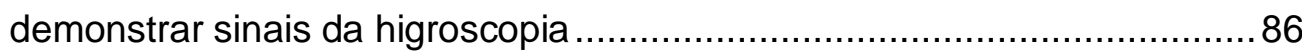

Figura 84 - Esfera 4 já dava sinais de passagem da água enquanto a

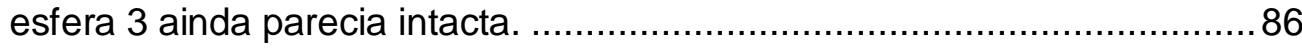

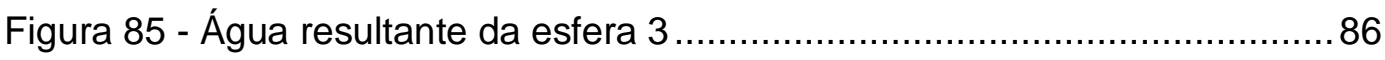

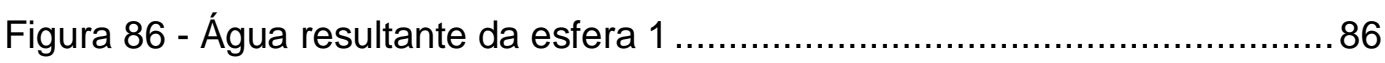

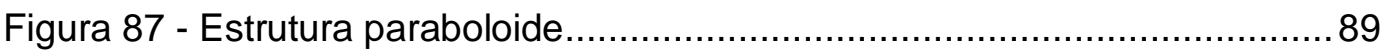

Figura 88 - Gestual para incorporação do barro no tecido...............................90

Figura 89 - Hidratação do tecido antes da mistura com o barro. .........................90

Figura 90 - Dedos e mãos pressionando o compósto para este fixar na

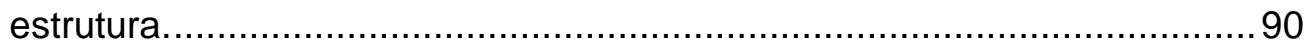

Figura 91 - Uso da tesoura para ajudar a manta a se fixar na estrutura.............90

Figura 92 - Manta de juta-barro sendo posta sobre o parabolóide.....................91

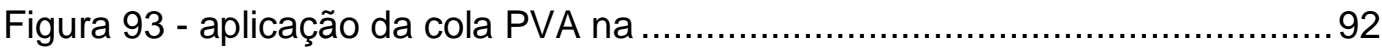

Figura 94 - Deterioração do rolo ao final da experimentação .superfície.............92

Figura 95 - Resultado da aplicação após algumas semanas ...........................92

Figura 96 - Aplicação com as mãos da goma na estrutura................................92

Figura 97 - Preparo coletivo das placas de fibrobarro ....................................99 94

Figura 98 - Exemplos gestuais de interação com o compósito...........................99

Figura 99 - Aluna usando a palma da mão para misturar as fibras ....................94

Figura 100 - Estudante usando batentes de madeira para homogeneizar a

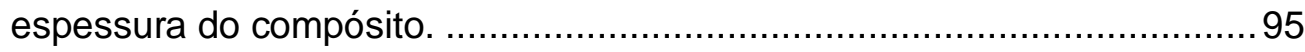

Figura 101 - Dupla transportando o compósito para aplicar na estrutura ...........95

Figura 102 - Pressionando a placa para melhorar sua fixação na estrutura .......96 
Figura 103 - Treliça montada com lona sendo reforçada na base ..................... 97

Figura 104- Treliça senda reforçada com ripas............................................. 97

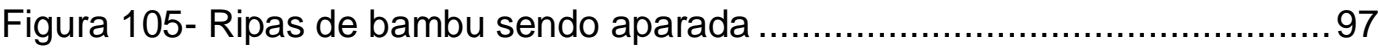

Figura 106 - Aplicação da placa na estrutura ...............................................98

Figura 107 - Funcionárias da Horta preparando os compósitos .........................98

Figura 108 - Avaliação semanal do que foi feito na semana anterior. .................99

Figura 109 - Pressionando a placa dos dois lados para fixar e vedar o bambu

Figura 110 - Pesquisadores da PUC aprendendo a produzir embira de banana 100

Figura 111 - Voluntários construindo mantas com barro e fibras de

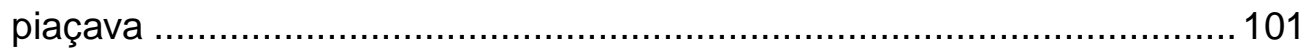

Figura 112 - Técnica de retirada do plastic suporte....................................... 101

Figura 113 - Minhocário em Agosto de 2011 e em Fevereiro de 2012 .............. 102

Figura 114 - Erosão no fibrobarro feita por uma goteira. Fibras ficam aparentes 103

Figura 115 - Miniatura da construção de dois icosaedros conjugados 104

Figura 116 - Estado da arte da construção em 1/03/2013 104

Figura 117 - Nova aplicação de barro em uma placa de fibrobarro seca

que perdeu um pouco da argila ............................................................ 105

Figura 118 - aplicando a aguada de barro para homogeneizar a superfície .....106

Figura 119 - lixando a superfície usando um retalho do feltro usado na

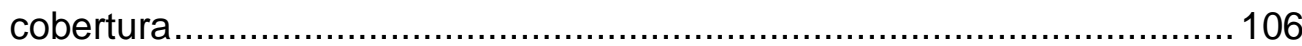

Figura 120 - Parede de fibrobarro em estado bruto......................................106

Figura 121 - Fibrobarro depois da aplicação da camada fina.......................... 106

Figura 122 - Primeira minitura do Túnel Expositor .......................................108

Figura 123 - Minitura do molde de fibrobarro ............................................108

Figura 124 - Processamento das fibras de sisal.......................................... 108

Figura 125 - Movimento de virarmos o compósito para aplicar barro do

outro lado. O gestual foi aprimorando a partir da prática 110

Figura 126 - Cada placa era construída especificamente para o local que seria aplicada.

Figura 127 - Terceiro módulo sendo construído enquanto os dois primeiros secavam

Figura 128 - Túnel Expositor visto de dentro.................................................113

Figura 129 - Túnel Expositor visto da entrada ............................................113

Figura 130 - Aplicação da pastacal utilizando pincel .....................................114 
Figura 131 - Aplicação da pastacal mais grossa utilizando um cartão de

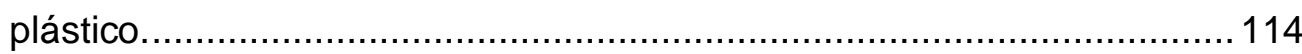

Figura 132 - efeito do gotejamento sobre a estrutura ...................................114

Figura 133 - Após a secagem os efeitos eram ainda mais visíveis. ................115

Figura 134 - Gotas de $1 \mathrm{~cm}$ de diâmetro marcando a superfície da estrutura enquanto não estava seca. .................................................... 115

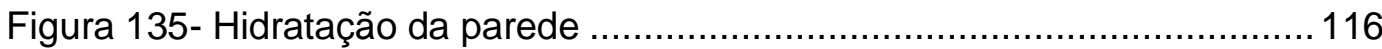

Figura 136- Hidratação e retirada das placas................................................116

Figura 137- Carretéis de fibrobarro para estocagem e futura reutilização ........117

Figura 138- Fibrobarro retirado apoiado sobre lonas. ..................................117

Figura 139 - Estrutura "stand" montada na Rio+20 …................................117

Figura 140 - Voluntárias construindo pequenas placas................................. 118

Figura 141 - Detalhes para que praticamente só as pontas dos dedos

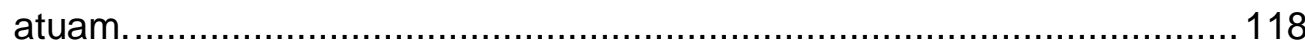

Figura 142 - Aplicação do fibro barro na estrutura ........................................119

Figura 143 - Fibrobarro sobre juta sobre a estrutura ....................................119

Figura 144 - Esqueleto inicial do Icosaedro.............................................121

Figura 145 - Grande manta de fibrobarro sendo transportada ....................... 122

Figura 146 - Quantidade de ripas e cordas na segunda tentativa ...................123

Figura 147 - Quantidade de ripas colocadas na primeira tentativa de

aplicar o fibrobarro. ...................................................................... 123

Figura 148 - Ao diminuir o número de placas a qualidade aumentou...............123

Figura 149 - Voluntário aplicando uma grande placa .................................... 123

Figura 150 - Uso do torso para alisar.......................................................... 125

Figura 151 - Uso do punho para aplicar.....................................................126

Figura 152 - Icosaedro coberto de pastacal e barro ....................................... 126

Figura 153 - Entrelaçamento das fibras de sisal na estrutura de ripas de

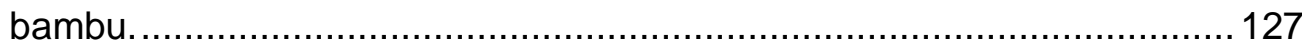

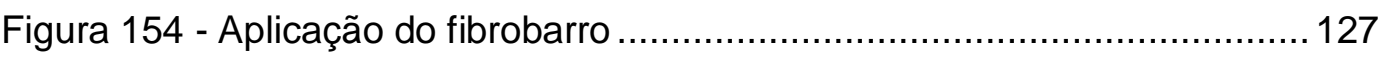

Figura 155 - Vista por baixo da estrutura de telhado..................................... 129

Figura 156 - Caibros apoiados sobre um mastro ......................................... 129

Figura 157- Rolete sendo usado para fazer a feltragem dos tecidos............... 129

Figura 158 - aplicação manual do barro na placa .........................................129

Figura 159 - Pincel com barro para homogeneizar a superfície interna do

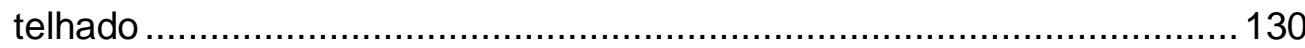

Figura 160 - Pincel com resina de mamona na parte externa do telhado.........130

Figura 161 - Manchas escuras na parte inferior sinalizando a passagem 
de água pela camada de resina 131

Figura 162 - Água aparentemente escorrendo na superfície.......................... 131

Figura 163 - aplicação do barro na tela sobre superfície .................................132

Figura 164 - Criança fixando a tela no molde usando martelo ........................ 132

Figura 165 - Parte interna ficou bem visível a aplicação do barro. ....................132

Figura 166 - Os dois lados da tela. No lado externo houve pouca passagem de barro da camada inferior ............................................... 132

Figura 167 - Duas vistas da treliça montada em forma de espiral ...................133

Figura 168 - Compósito do outro lado da aplicação. Detalhe para a treliça apoiada no pilar de concreto que fabricamos....................................... 134

Figura 169 - Crianças de 8 anos aplicando o fibrobarro................................ 134

Figura 170 - Parte interna da espiral ........................................................ 134

Figura 171 - Parte externa da espiral coberta com lona azul ......................... 134

Figura 172 - Parte externa da espiral .......................................................... 135

Figura 173 - Parte interna da espiral .......................................................... 135

Figura 174 - Construção junto com as crianças ajudou na integração delas com o espaço

Figura 175 - Cada coloração na parede representa um tipo de acabamento experimentado

Figura 176 - Pintura de cal das paredes externas e internas. O teste que a princípio era só para observar a deterioração durou muito mais do que o esperado.

Figura 177 - Detalhe de parte da camada que caiu e foi facilmente reconstituída com nova aplicação.

Figura 178 - "Mancha" de terra na verdade veio do telhado verde. Parede ficou intacta apesar da goteira.

Figura 179 - Casa vista de dentro. Amplamente utilizada e perfeitamente assimilada.

Figura 180- Visão externa da casa e suas paredes "testando" diferentes tipos de cobertura. 


\section{Introdução}

Construções que utilizam princípios ecológicos de aproveitamento dos materiais disponíveis, também chamada de Bioarquitetura ou construção com terra crua, são sistemas construtivos utilizados há mais de 9.000 anos. Viabilizados através de processos de baixo impacto ambiental utilizando recursos disponíveis no ecossistema socioambiental ao redor e vistos em interação com os sistemas de ações da natureza, normalmente são produzidos através do sistema gestual humano.

A interação entre os sistemas de materiais, técnicas e pessoas é mais do que a soma de partes isoladas e deve ser vista em conjunto para um real entendimento do valor deste tipo de construção. Tradicionalmente feita por grupos de jovens, idosos e adultos, promove a integração com a comunidade justamente por permitir que diferentes saberes e tipos possam atuar juntos em cooperação. (Associação Centro da Terra 2005)

A utilização de materiais biocompatíveis para construção de espaços vai além do aproveitamento do espaço e da técnica. Desenvolve e estimula autonomia e soberania ao possibilitarem que o construtor-habitante tenha acesso aos meios de produção e manutenção do objeto. Sistemas extremamente industrializados, além de produzir muitos resíduos indesejados e prejudiciais à saúde, tornam a relação consumidor-sistema de produção distante, dependente e alienada.

\subsection{Questões norteadoras}

O contexto social, econômico, histórico e até mesmo o ambiental, alterouse muito antes das construções com materiais biocompatíveis serem novamente valorizadas. Descobertas nos campos técnicos e científicos das áreas que tratam da construção do objeto em nível arquitetônico precisam ser incluídas para aumentar a capacidade, eficiência, abrangência, simpatia e interesse aos sistemas biocompatíveis. Do início do século XXI, quando a presente pesquisa começou a ser desenvolvida, até os dias de hoje, incluir e divulgar novos e antigos saberes ainda se fazem necessários. 
Dentre os desafios apresentados, há a proteção destas construções contra o excesso de chuvas e umidade que podem acelerar a degradação dos materiais. Proteger as construções sem que haja a perda das suas principais características deve ser desenvolvida.

Também é extremamente válido o desenvolvimento de tecnologias de acordo com o ecossistema local. Esta integração deve considerar não somente fatores climáticos, mas também as características geográficas, sociais e históricas para que os objetos desenvolvidos possam realmente ser assimilados e reproduzidos pela comunidade local.

Uma das questões que surgiu no processo de construção com materiais naturais foi a proteção destas estruturas em condições de chuvas, umidade e mudanças de temperatura, que aceleram o processo de degradação dos materiais. Considerando a abundância de chuvas existentes no Brasil, torna-se extremamente pertinente o estudo de sistemas que retardem ou impeçam o processo de erosão sem que haja perda das propriedades de conforto térmico e possibilidades de reaproveitamento dos materiais.

Outra questão da pesquisa seria observar os sistemas de objetos, ações e conceitos dos processos construtivos. Assim como verificar as propriedades de sistemas construtivos de proteção que mantenham as características homeotérmicas e higrométricas como a cal hidratada, fibras vegetais, resinas naturais industrializadas ou não, isoladas ou consorciadas aplicadas dentro e fora do laboratório. Quando inseridas em grupos sociais, estas técnicas podem mostrar indicativos da sua praticidade e aplicabilidade.

\subsection{Objeto da pesquisa}

O tema escolhido para a dissertação encontrou na linha de pesquisa "Design, meio ambiente e sociedade" espaço para o desenvolvimento da pesquisa. O LILD (Laboratório Investigativo em Livre Desenho) tem como foco de pesquisa o desenvolvimento de objetos e técnicas que utilizem materiais que possam ser manipulados e reproduzidos pelo gestual humano em diferentes contextos. A inspiração vem da natureza que em suas construções aproveita com economia a energia potencial da matéria na realização de suas formas.

A partir da proposta do laboratório definimos que o tema da pesquisa seria: estudo e levantamento de materiais e processos de construção de camadas superficiais de proteção e acabamento de objetos em escala arquitetônica de 
mobiliário fazendo a pesquisa dentro do laboratório e em contextos externos. Este estudo deve incluir sistemas construtivos de fabricação através de processos que minimizem o impacto ambiental e que são vistos em interação com os sistemas de ações da natureza e produzidos através do sistema gestual humano.

\subsection{Objetivo Geral e objetivos específicos.}

Segundo as palavras do nosso orientador, J.L.M. Ripper, presente a dissertação está voltada para o estudo de materiais e processos sobre acabamentos das superfícies de materiais biocompatíveis, como a terra crua, que atuem como filtros seletivos que controlam a passagem de fluídos aéreos e que retenham a água da chuva nos casos das paredes externas.

A partir da experiência pessoal e das vivências dentro do laboratório em companhia de outros pesquisadores e colaboradores sobre os possíveis caminhos da pesquisa, foi definido que o objetivo geral seria o de estudar diferentes camadas de cobertura que pudessem revestir e preservar construções com materiais naturais.

Com a definição do objetivo geral, e das práticas dentro e fora do laboratório, foi possível definir quais seriam os objetivos específicos da pesquisa. O desenvolvimento de objetivos que pudessem contribuir integradamente ajudou a definir os objetivos específicos como:

- Identificar materiais e desenvolver técnicas de camadas biocompatíveis que possam atuar como camada de cobertura;

- Estudar a aplicação do assunto pesquisado em contextos de grupo sociais para avaliação qualitativa das suas possibilidades.

- Desenvolver técnicas de aplicação de diferentes camadas com diferentes composições;

- Verificar a estanqueidade das camadas à água através de experimentos estáticos em laboratório fixo;

- Aplicar as técnicas em espaços sociais, com participação coletiva, para observar a facilidade de apropriação das técnicas e do objeto em si.

- Fazer das construções laboratórios de campo, estimulando o espírito investigativo de todos os participantes, quanto a estanqueidade às águas da chuva e o cuidado na execução de estruturas estáveis. 


\subsection{Justificativa e relevância da pesquisa}

Construir com terra faz parte dos primórdios de construções de diversas civilizações antigas com exemplares disponíveis em diversas partes do globo terrestre. Usando diferentes técnicas, muitas foram erguidas e permanecem quase intactas há mais de três mil anos. Segundo Khalili (Khalili 2005) a atual tecnologia somente consegue compreender materiais trabalhando isoladamente, enquanto as construções com terra crua, e outros materiais biocompatíveis, costumam conviver mais harmoniosamente com a natureza e seus construtores são mais sensíveis às ações humanas envolvidas.

No início do século XXI, ocorrem iniciativas de resgate de materiais e técnicas antigas e esquecidas. Métodos esses agora valorizados pelo seu respeito pela natureza, pelo bem estar social e por atenderem os requisitos da inclusão social e de uma distribuição mais justa dos bens, das informações e do acesso aos conhecimentos. A mescla entre as antigas técnicas e os novos conceitos de design ainda pode ser muito explorada para o desenvolvimento de novas alternativas.

Uma das metas dessa pesquisa foi desenvolvê-la utilizando, como objeto de estudo, grupos que estivessem em locais em plena atividade. $O$ elemento de estudo, a ação do designer e seus produtos é resultante da aplicação da pesquisa no meio físico e social e das reformulações intelectuais de acordo com os dados obtidos na experiência concreta. Alguns dos processos estudados estão inseridos dentro dos fundamentos conceituais de economia leve e desenvolvimento sustentável (Kazazian, Thierry 2005), que estuda os efeitos da ação humana sobre o meio ambiente e apresenta proposta de diminuí-los através da concepção de produtos e serviços planejados em fluxos de energia controlados que se aproximam da dinâmica utilizada pela natureza na geração e manutenção de seus ecossistemas.

Portanto, o tema escolhido trata de questões referentes aos processos que afetam a vida cotidiana e o bem-estar da sociedade e do meio ambiente como um todo, procurando vislumbrar possibilidades para conciliar a produção tecnológica e material dentro de padrões éticos de desenvolvimento sustentável e suas próprias metas de gerar saúde, prosperidade e preservação da humanidade na vida planetária. 


\subsection{Métodos e Técnicas de Pesquisa}

Por se tratar de uma pesquisa que inclui, em seus preceitos, a aplicação em contextos sociais valorizando a temática nativa e as possíveis ações já existentes, fez-se necessário a aplicação de uma metodologia de pesquisa experimental com constante aplicação em contextos sociais. Neste modelo de pesquisa, o pesquisador, segundo Gil (Gil 2010) torna-se mais do que um observador para ser um agente ativo. É importante ressaltar que as técnicas, os métodos e até mesmo a abordagem empregada devem estar próximos à realidade do contexto social local. Esta linha de pesquisa tem como principais características a constante transição entre as fases e a exigência de uma constante relação entre pesquisador, assunto pesquisado e comunidade local.

A constante transição entre o laboratório e a pesquisa de campo aumentaram as possiblidades de análise quanto à viabilidade do objeto de estudo. A pesquisa com concomitante troca de aprendizados entre laboratóriorealidade faz parte da metodologia do LILD e enriqueceu a dissertação fornecendo novas técnicas, materiais e possibilidades de uso.

Becker (Becker 1994) comparou a abordagem da pesquisa em ciências sociais com a metáfora de construção de uma casa. Segundo este autor, por mais que conheçamos diversas técnicas, ao construirmos um objeto arquitetônico devemos escolher as técnicas e métodos de acordo com as possibilidades de cada local. Este pensamento encontra ainda mais ressonância se consideramos que o princípio de construção ecológica é o do respeito pelas características ambientais locais para escolha das técnicas mais apropriadas.

Desde o início da elaboração desta pesquisa, foram feitos experimentos em corpos de prova no LILD. Esta ação nos permitiu a observação sistemática dos procedimentos, técnicas e materiais necessários antes, durante e após construção das camadas.

A pesquisa, ao ser aplicada no campo, forneceu outros dados, materiais e técnicas que enriqueceram a dissertação justamente por possibilitar novos encontros e interpretações. Também permitiu a coleta de dados quanto à viabilidade da proposta em diferentes grupos sociais e se o assunto instigava a apropriação das técnicas e o uso dos objetos. Nesse sentido, o trabalho de campo tornou-se também um laboratório local. 


\subsection{Divisão dos capítulos}

O segundo capítulo é dedicado a fazer a fundamentação teórica da pesquisa. Autores como Schumacher (1973), Associação Centro da Terra (2005), Boff (1999), Fathy (1982), Forty (2010), Harvey (2010), Illich (1976), Kazazian (2005), Khalili (2005), Santos (2010) e outros nos ajudaram a descrever um panorama da atual sociedade ocidental do início do século XXI, bem como as vantagens de uma tecnologia mais harmônica com o meio ambiente e social. No fim do capítulo também serão descritos alguns dos desafios culturais que as construções com materiais biocompatíveis enfrentam.

O terceiro capítulo é dedicado a relatar alguns materiais e técnicas utilizados em algumas localidades ao redor do mundo. Esta parte da pesquisa auxiliou a estabelecer princípios atitudinais, técnicos, além de materiais passíveis de serem usados como camada de cobertura. Autores como Allen (2011), Guelberth \& Chiras (2009), Huizinga (2008), Marangoni (2000), Weismann \& Bryce (2011), Snell \& Callahan (2009), Rascusin \& McArleton (2012) e Pedrotti (2006) ajudaram a estabelecer parâmetros de ação.

No mesmo capítulo é descrito algumas das pesquisas anteriores desenvolvidas no LILD. Esta parte do capítulo serviu para a percepção do estado da arte do LILD até o início da pesquisa. É possível destacar as pesquisas desenvolvidas por Côrtes (1999), Leme (2003 e 2008) e Xavier (2009), leituras essenciais para a compreensão do trabalho já realizado e o funcionamento da pesquisa.

No quarto capítulo são relatados os experimentos práticos que feitos dentro das dependências do LILD. Apesar de terem sido feitos simultaneamente com a pesquisa de campo, esta separação foi feita porque neste ambiente é mais fácil controlar e observar algumas etapas do processo de aprendizado e pesquisa.

O quinto capítulo é voltado para os estudos de casos que realizamos ao longo de mais de dois anos de pesquisa. É descrito o contexto socioambiental dos que construíram e usaram os experimentos. Também procuramos relatar o que foi possível observar antes, durante e depois do processo de construção dos objetos. 


\subsection{Motivação Pessoal}

Durante toda minha formação acadêmica, sempre houve o interesse em projetos que trabalhassem de maneira harmônica com a natureza. Ao ingressar no curso de Design da PUC-Rio em 1996, logo me identifiquei com a metodologia de pesquisa da professora Ana Branco e do professor Ripper de trabalhar diretamente em contextos sociais ativos buscando a fartura destes lugares. A metodologia de priorizar a autopoiese (Maturana e Varela 2004) local norteou meus trabalhos desde o primeiro período.

No meu último ano de universidade descobri a permacultura (Mollison 2002) e as práticas de construção que consideram não apenas os materiais, mas também os movimentos da natureza para a construção de habitações. Desde então, venho aprendendo e construindo junto com outros que, assim como eu, acreditem no valor do fazer manual como fonte de crescimento pessoal e social. 


\section{Conceitos da pesquisa}

Todo o desenvolvimento tecnológico deve estar a serviço da sociedade sem comprometer o seu futuro ou o de outras sociedades e sistemas (Schumacher 1973). Seguindo este preceito, este capítulo é dedicado a apontar justificativas da necessidade de rever os conceitos vigentes de construção.

Na primeira parte do capítulo serão relatados os motivos que indicam que a sociedade brasileira do início do século XXI começou a perceber que o atual modelo de desenvolvimento, além de injusto socialmente, é fadado a falhar por não considerar elementos ambientais e sociais óbvios, como o custo ambiental da produção e o que acontece depois dos objetos serem descartados.

$\mathrm{Na}$ segunda parte deste capítulo, serão mostradas as vantagens de um novo modelo de construção que respeite os ecossistemas da sociedade e da natureza. Neste item, o fator da transformação social das construções com materiais biocompatíveis fica mais evidente.

No final do capítulo, é descrito alguns desafios que esta nova abordagem aqui endossada encontra para que possa ser difundida para outros grupos sociais. É descrito o quanto a lógica vigente interfere na interpretação das técnicas que usam materiais naturais não industrializados e não considera os usuários e as consequências das ações.

\subsection{Crise do modelo convencional de construção}

O homem se destaca por ser o mamífero que mais altera seu meio para gerar conforto. Como já foi dito anteriormente, técnicas antigas que usavam materiais in natura neste processo de construção durante muitos séculos ficaram praticamente de lado em virtude de outras mais desenvolvidas nos conceitos industrializados das sociedades de consumo capitalista. No final do século $X X$, os processos industrializados já eram questionados pela sua falta de capacidade de suprir os interesses da população sem comprometer suas fontes de recursos naturais (Schumacher 1973).

A pesquisa em estudos das camadas externas das construções com materiais biocompatíveis contraria a lógica mercadológica de padronização dos 
espaços, fazeres e objetos sem o devido respeito com às características locais do ambiente e da sociedade. Este tipo de construção, também denominado por alguns autores de bioarquitetura (Soares 2001), são sistemas construtivos que vêm sendo aplicados há muitos séculos e que, após um período de verdadeiro ostracismo por muitas sociedades, no final do século XX deu indícios de uma redescoberta do seu valor, em uma cultura que começa a questionar, mesmo que timidamente, seus sistemas produtivos (Associação Centro da Terra 2005). Esses antigos saberes que utilizavam processos de baixo impacto ambiental em interação com os sistemas de ações da natureza e produzidos através de sistemas gestuais humanos, foi durante muitos anos, principalmente no período pós-revolução industrial, preterida por técnicas e materiais, em princípio, mais eficientes.

Segundo Boff (1999), uma das consequências foi o crescimento desordenado do meio urbano. Tornou cada vez mais comum a perda do contato com o ambiente natural. Somando isso a fatores como os considerados "mazelas" do crescimento desordenado (violência, falta de espaço, infraestrutura e outros), e o desenvolvimento das comunicações à distância promoveu um isolamento cada vez maior entre os integrantes da sociedade.

Schumacher (1973), classifica que o homem moderno achou que seu papel no planeta colocar todos os outros seres e recusos a seu favor. Com isso recursos finitos como o petróleo são gastos como se sua fonte fosse inesgotável ou que o encontro de outra fonte energética seria uma questão de tempo. Ambos os conceitos estão, no mínimo, equivocados. O economista ainda pergunta como é possível crescer infinitamente em um mundo onde os recursos são finitos ? ${ }^{1}$

De acordo o arquiteto Fernando Pinto (Associação Centro da Terra 2005), a era das construções que despendem grande quantidade de energia e o uso indiscriminado de materiais está chegando ao fim restituindo a construção com terra e outros materiais naturais como pontos fundamentais para a construção do habitat humano. Estes materiais devem ser pensados justamente por suas características de acessibilidade, capacidade térmica e higrométrica.

Do ponto de vista ideológico, Harvey (2010, capítulo 2) cita que o surgimento do modernismo está atrelado a uma sistemática destruição do passado para construção de um novo mundo. Esta visão claramente positivista ajuda a entender o porquê o modelo de casa, especialmente aquele que usava

\footnotetext{
1 “...how much further 'growth' will be possible, since infinite growth in a finite environment is an obvious impossibility' (Schumacher 1973, 40)
} 
terra crua, foi tão desvalorizado para uma promessa de nova era. Isso é tão arraigado na nossa cultura que uma das primeiras associações que se faz quando se pensa em casa de terra crua são as casas de pau-a-pique feitas pelas comunidades miseráveis da região nordeste, enquanto exemplos coloniais como as da cidade de Paraty, Igrejas, Instituições como a Casa França-Brasil ou o Solar Grandjean de Montigny (PUC-Rio,

Figura 1) não são incluídas nessa associação. Com exemplos feitos a mais de 9.000 anos e virtualmente impossíveis de serem demolidos devido ao seu valor histórico, a "destruição" das casas de terra crua foi feita no campo ideológico tornando símbolo de construções insalubres e de má qualidade.

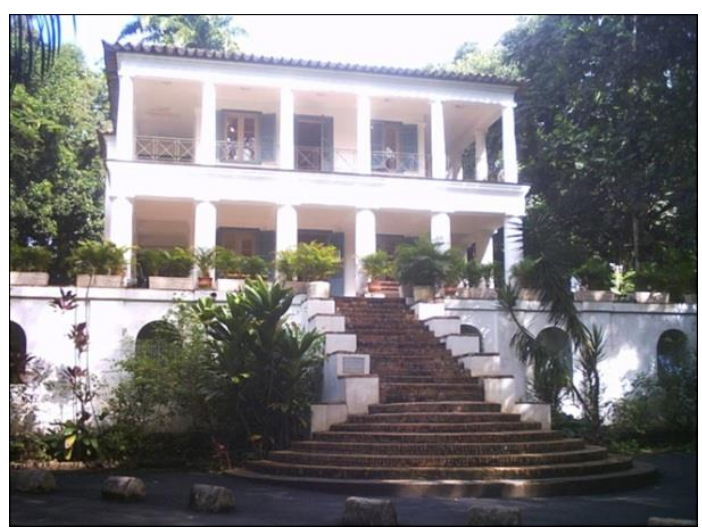

Figura 1 - Solar Grandjean de Montigny - PUC-Rio. 2008. Construção de terra crua de 1830. Fonte: http://www.puc-rio.br/ sobrepuc/depto/solar/index.html

A compressão do tempo e do espaço, impede o surgimento de uma real experimentação e questionamento das construções do início do século XXI. As soluções são sempre as mesmas porque o tempo comprimido, a urgência, estimula a busca pelo que já está consagrado pelo uso. Afinal, estes modelos já funcionam para o imediatista sistema capitalista (Harvey 2010). Como vimos ao longo de todo o livro do Forty (Forty 2010), qualquer mudança não será feita pela melhoria da eficiência ou pelos avanços tecnológicos mas sim pelo lucro. Harvey ainda ressalta no capítulo 14 de que o domínio feito pelo capital acontece através do domínio do espaço e do tempo criando regras e barreiras para que protejam o capital de giro, fomentando uma crescente fragmentação e efemeridade de tudo.

As construções com terra crua, assim como outros materiais naturais, tem grande possibilidade de ser incluída no sistema capitalista pela necessidade do mesmo de criar os meios para a sua manutenção. Autores como (Minke, 
Building with earth: design and technologyof a susteinable architecture 2009) e o já citado Pinto (in Associação Centro da Terra, 2005) já preveem um esgotamento dos materiais convencionais de construção.

Forty (2010) também disse que quando há o esgotamento do mercado, é comum a busca por novos meios de ampliação do lucro. Outro exemplo desta linha de raciocínio é a que podemos chamar de "indústria de despoluição". Durante décadas a indústria promoveu uma total desconsideração com o meio ambiente poluindo-o, não pela simples ignorância mas muito mais porque preocupar-se com isso e tomar uma atitude a esse respeito era sinônimo de custo e perda de lucros, afinal a natureza não "cobra" diretamente pelo seus materiais (Schumacher 1973). No inicio do século XXI, é possível perceber um grande aumento da reciclagem dos materiais descartados sem que haja uma real diminuição da produção de lixo. Estas medidas normalmente só acontecem porque há valorização das empresas que conseguem associar sua marca a palavras como "ecologicamente responsável" ou "verde".

\subsection{Construções com materiais biocompatíveis como fonte de transformação social}

A construção com terra crua promove o trabalho em grupo, usando principalmente materiais e técnicas acessíveis e adaptadas ao contexto sociocultural de cada localidade. Este tipo de metodologia construtiva ajuda a desenvolver valores e linhas de pensamento mais harmônicas e eficientes em relação ao contexto sociocultural da civilização brasileira.

No início do século XXI é possível perceber uma mudança de postura dos profissionais das áreas de engenharia, arquitetura, design e demais profissões, em busca de uma maior responsabilidade socioambiental, visando minimizar impactos das ações produtivas sobre o meio ambiente e sobre as populações afetadas. Mesmo que este processo ainda ocorra de maneira lenta e questionada, inclusive pelos próprios colegas pesquisadores, o desenvolvimento de tecnologias que promovam o respeito pela natureza, o bem estar social e atendam aos requisitos da inclusão social e a uma distribuição mais justa dos bens, das informações e do acesso aos conhecimentos cresce de maneira gradual não só devido às suas qualidades, mas também pela deterioração do sistema ambiental, provocada pelo sistema industrial vigente.

Um dos fatores que contribuem para o crescimento da popularidade deste método construtivo é a mescla que promove entre as antigas técnicas e os 
novos conceitos de design e materiais. Schumacher (1973, p. 20) propõe o desenvolvimento de tecnologias em escala menor para que novos tipos de parceria possam desenvolver "tecnologias com cara de gente"2.

Analisando do ponto de vista econômico, podem-se usar os argumentos de Minke (Minke, Manual de construccion em tierra: la tierra como material de construcción y sus aplicaciones em la arquitectura actual 1999) que diz que os métodos de construção industrializados usados pela sociedade ocidental não são suficientes, nem produtivamente, nem financeiramente, para suprir as necessidades de habitação para mais de um terço da população mundial. Por este motivo, o autor acredita que a construção com terra cresce em demanda apesar da pressão política e econômica de governos e de segmentos da indústria. Também segundo Gernot Minke (Minke, Building with earth: design and technologyof a susteinable architecture 2009), técnicas de construção com a terra também beneficiam a autoconstrução e independência do usuário em terceirizar todo o processo de construção da sua casa, além ser uma matériaprima reutilizável.

Ainda na década de 1970, Illich (Illich 1976)e Schumacher (1973) relataram de diferentes maneiras que o afastamento do homem da natureza e do fazer manual o torna um indivíduo isolado afetando, principalmente, seu processo criativo. Uma das consequências da ausência de uma vida participativa é, somado a outros fatores, um desinteresse pelo meio ambiente, por simplesmente ignorar que todo o objeto deve ser visto e analisado a partir do contexto em que está inserido (Santos 2010).

Todo desenvolvimento tecnológico deve considerar o impacto socioambiental que ele provoca no meio em que é inserido. Caso a sua inserção não seja benéfica é preciso que tal aparato seja substituído ou usado com sabedoria (Illich 1976). Construções com terra crua e outros materiais biocompatíveis fazem parte do gestual tradicional de uma época pré-Revolução Industrial. Naquela época e agora, sua apropriação implica em autonomia e consciência das possibilidades do meio, devolvendo ao indivíduo a dignidade de poder decidir.

Ao construir utilizando os recursos disponíveis no ecossistema local, segundo Schumacher (1972), é atitude mais racional já que desta forma é possível aumentar a independência de fatores externos. Este autor ainda enfatiza que as novas tecnologias que surgirem para serem realmente

\footnotetext{
2 'technology with a human face' (Schumacher, 1973, p. 20)
} 
ecológicas e úteis à humanidade precisa que seus custos possam ser acessíveis a virtualmente todas as pessoas; concebíveis de serem aplicadas em pequena escala e compatíveis para que o homem ainda consiga ser criativo ao manuseála.

\subsection{Desafios para as construções com materiais biocompatíveis}

Apesar de qualquer mudança na sociedade está atrelada a um ganho por parte dos controladores da noção de tempo e espaço (Harvey 2010), o design, ou qualquer outra profissão que trabalhe no meio social, deve sempre buscar alternativas para a produção de saberes exija outras noções de tempo e espaço.

Para as construções com materiais biocompatíveis possam ser realmente aceitas pela sociedade é preciso também romper os pré-conceitos existentes de que este tipo de construção é para quem não tem recursos financeiros ou que a própria construção não é resistente. Pierre Bourdieu (Bordieu 2009) menciona a tríade formada pela Produção (do designer ou artista), pela Recepção (do público) e pela Circulação (Instâncias de legitimação do que era produzido). A Instância de Circulação é a responsável pela legitimação e consagração dos objetos de acordo com os valores estéticos e "extra-estéticos". O fato de a presente pesquisa estar inserida dentro do ambiente universitário mostra indícios de que a construção com terra começa a voltar a ser legitimada para ser aceita pelo público brasileiro (Recepção).

Movimentos que contrariam os conceitos vigentes do consumismo e buscam os movimentos e objetos já disponíveis e de baixo custo socioeconômico e ambiental costumam encontrar muita resistência. Essas características são pouco atrativas para o sistema capitalista que busca o aumento incessante do capital de giro sem uma reflexão ou preocupação sobre as consequências destes atos (Harvey 2010).

Atualmente é muito mais interessante para o sistema capitalista o indivíduo gastar construindo sua casa e depois gastar novamente desconstruindo ou reformando a casa do que simplesmente ter a possibilidade de reaproveitamento do material ou gastar menos com ele (Forty 2010).

A presente pesquisa contrapõe este sistema por propor materiais e processos que possibilitam o reaproveitamento e uma de reflexão crítica. Isto ocorre porque não há uma padronização das matérias-primas justamente por não passarem por um processo de industrialização exigindo uma maior atenção de quem manipula os materiais. 
O entendimento da desvalorização da casa de terra crua é ampliado na obra de Forty (Forty 2010), especialmente nos capítulos que falam sobre o conceito de higiene e da implementação da ideologia de economia de trabalho no lar. No Capítulo de higiene e limpeza é possível perceber que, em torno do ano de 1880, na Inglaterra, houve uma valorização do ambiente asséptico. A sujeira e o que pudesse provocar sujeira foram execrados sistematicamente da sociedade. Acreditamos que a construção de sistemas de terra crua foram desvalorizados por sua ligação direta com o ambiente natural, nesta época fonte de todos os males, enquanto outros sistemas de construção utilizava elementos "higienizados" já que eram feitos à altas temperaturas e muito mais modernos que as antigas técnicas.

Com um tempo de secagem mais rápido do que a construção com terra, produtos manufaturados com cimento prometem requerer menos manutenção e aumento da praticidade da mesma forma que produtos como aspirador de pó e máquina de lavar prometiam. Materiais feitos com cimento realmente têm uma resistência mecânica maior, mas o caso é que nem sempre são realmente necessários. Alguns objetos arquitetônicos seriam muito mais viáveis econômica e socialmente se considerassem que o tempo de uso dos objetos não é o mesmo.

Outro fator que precisa ser compreendido é que qualquer construção, independente do material, requer uma manutenção periódica. Ao que tudo indica casa de terra crua realmente precisa de uma manutenção em períodos mais curtos, contudo seu custo, não apenas o monetário é mais baixo em comparação ao sistema de alvenaria vigente.

Além disso, Forty (Forty 2010), relata que é possível perceber que o desenvolvimento tecnológico, que poderia ter promovido a qualidade do trabalho reduzindo o tempo de produção do indivíduo, só aumentou a exploração do proletariado. Esse deslumbramento com as novas máquinas, que acontece até hoje, pode explicar porque técnicas que incluem o gestual humano foram preteridas pelas que usavam materiais industrializados e excluíam o máximo possível a ação humana.

Uma possível tática de divulgação e ampliação da prática de construção com terra crua é vislumbrada no capítulo sobre a diferenciação no design do Forty (Forty 2010). Neste capítulo, o autor conta que a burguesia buscou diferenciar da classe operária quando esta foi capaz de ter roupas similares aos patrões. Aumentar a qualidade, o requinte e valor da construção com terra crua, facilmente associada `as construções ecológicas, pode justamente fazer o efeito 
de popularizar a técnica devido a um valor agregado. As classes dominantes apropriando-se deste repertório técnico o alcance para as classes mais pobres fica facilitado. Com isso a justificativa de refinar a qualidade do acabamento deste tipo de construção ajuda a agregar valor e a durabilidade da construção.

O consumo desenfreado, sem considerar a origem e o descarte dos materiais dificulta o uso de materiais que precisam que seus ciclos biológicos sejam respeitados (Kazazian, Thierry 2005). Para a escolha dos materiais, Pedrotti (Pedrotti 2006) aconselha que os materiais utilizados devem estar disponíveis no local. Outro ponto que este pesquisador acrescenta que é necessário garantir que o máximo possível de elementos não sejam nocivos às pessoas e ao meio ambiente. Também é importante que os materiais possam ser reciclados.

Hassan Fathy (Fathy 1982) enfatiza que a questão mundial da habitação, em parte, está relacionada com a questão da maioria dos desprovidos dependerem de outros para obterem o que precisam. No caso da habitação, a necessidade de um arquiteto, do engenheiro e do acesso aos materiais manufaturados afasta o homem de promover os meios de sua subsistência. Fathy foca suas questões no homem do campo, mas se refletirmos sobre o crescimento desordenado das cidades e as previsões de escassez energética e material que se vislumbra, é necessário que toda população, principalmente os jovens, do campo e da cidade, revejam os conceitos de consumo de materiais.

Para que realmente haja a construção de novos objetos mais eficientes energeticamente e harmônicos nas áreas sociais e ambientais o designer tem a obrigatoriedade de analisar o objeto que projeta a partir do contexto que ele está. Como relatou Milton Santos (2009, capítulo 2), deve-se considerar os objetos dentro do seu contexto social e ambiental e, com isso, o objeto projetado pelo designer deve considerar toda sua produção, da origem ao descarte.

Hoje em dia, vive-se em uma era em que a esperteza é mais valorizada do que a sabedoria. Para verdadeiramente suplantar essa filosofia, é preciso o desenvolvimento de valores de que somente com educação, organização e perseverança é possível encontrar verdadeiras soluções para as questões econômicas, sociais e ambientais (Schumacher 1973). 


\section{Revisão bibliográfica dos métodos e materiais para a confecção de camadas de cobertura}

Neste capítulo são relatados alguns materiais e técnicas já utilizados para proteger construções com materiais biocompatíveis, como o bambu e o barro. Serão relatados autores que abordaram o acabamento nesses tipos de construção e o que estes dizem sobre os materiais e técnicas que utilizam.

$\mathrm{Na}$ segunda parte do capítulo são contadas algumas das possibilidades de acabamento estudadas e aplicadas por outros pesquisadores que colaboraram com a linha de pesquisa do LILD. Quando possível, será relatado o estado da pesquisa após o relato dos pesquisadores abordados. Este capítulo tem a intenção de revisar as pesquisas realizadas anteriormente, que contribuíram como referencial técnico e metodológico da pesquisa.

\subsection{Materiais de origem mineral}

Neste trecho iremos relatar o que aprendemos de possibilidades segundo alguns autores sobre materiais de revestimento que têm em sua origem recursos minerais. Procuramos também relatar as características destes materiais e alguns possíveis usos que pudemos perceber a partir do que foi dito pelos autores

\subsubsection{Betume}

Um dos primeiros materiais de que se tem notícia de ter sido usado como impermeabilizante, o betume ou piche, como também é conhecido, era a denominação de petróleo em estado bruto já encontrado na Antiguidade. Cunha (Cunha 2009) cita a passagem bíblica do Êxodo (capítulo 2). Segundo o autor, neste trecho há o relato de que o junco foi revestido com estes dois materiais para construir a arca que o menino Moisés seria transportado para descer o rio.

Apesar de Cunha citar esta passagem o autor afirma que, devido as condições climáticas da região de pouca umidade e precipitação de chuva, o betume era mais amplamente usado como argamassa misturada ao barro nos tijolos de adobe pelo seu poder aglutinante. 
Atualmente com o grande aumento da dependência da nossa sociedade, da indústria petroquímica, é difícil encontrar este material em estado bruto. Há alternativas sintéticas disponíveis no mercado mas o seu custo socioambiental é alto.

\subsubsection{Terra crua}

Formado por argila, areia e silt, a terra crua ou barro como é chamado no LILD, é um dos materiais mais abundantes na maioria das regiões do planeta. Suas vantagens são muitas principalmente se construirmos próximo ao local de retirada e não for processado pelo cozimento. Desta forma o custo de transporte é praticamente zero na construção e o reaproveitamento é total no momento de descarte do material. Como exemplo, Hassan Fathy relata que chegou a construir uma casa de adobe que custou praticamente um sétimo da equivalente de alvenaria sendo que a sua construção era muito mais interessante e saudável que a feita de alvenaria convencional (Fathy 1982, 28).

Segundo Guelberth \& Chiras (2009) camadas de cobertura feitas de barro, especialmente as mais ricas em argila, têm a capacidade de serem resistente à ação direta da água, no caso de chuvas, e permitir a passagem do vapor d'agua. Segundo estes autores as moléculas de barro nas camadas mais externas das paredes são envolvidas por moléculas de água mantendo as camadas mais afastadas da superfície secas. Seu tempo de secagem também é mais rápido do que os materiais convencionais como $o$.

É importante enfatizar que os autores citados falam em resistência à água e não proteção. Com a contínua ação da chuva, do vento e das alterações na temperatura é relatado que as paredes apresentam alguma erosão superficial. Outra característica do material é a erosão por atrito superficial. Estas falhas e fissuras podem ser resolvidas com uma nova camada colocada periodicamente para regenerar a camada de cobertura. Segundo Minke (2009), caso não tenha mais aditivos para proteção diante das variações do clima, é importante uma manutenção sazonal para garantir a durabilidade da estrutura.

Tanto a argila quanto a areia são importantes, segundo Snell \& Callahan (2009), pois a maior variedade de materiais contribui para a resistência da camada de cobertura. A argila tem a função de dar elasticidade à camada, enquanto a areia provê a resistência e ajuda a evitar fissuras. A maior diferença talvez seja que a cada camada mais externa busca-se dimuir a granulometria 
para se ter um melhor acabamento sendo que esta não deve ser maior que $3 \mathrm{~mm}$ nas primeiras camadas.

Aplicado em áreas com grande precipitação de chuvas as paredes com acabamento com barro tem baixa resitência às intempéries e força estrutural. Amplamente encontrado na maioria das regiões, seu impacto socio-ambiental é considerado o mais baixo (Rascusin e McArleton 2012).

Em regiões de pouca chuva e clima seco como no Vale do Supe, região ao norte de Lima, no Peru, no ano 3000 a.C., há indícios de uma técnica similar ao pau-a-pique revestida de barro, especialmente em divisórias e em paredes externas. Em alguns pontos, ainda é possível perceber um acabamento impecável com paredes lisas e até o uso de tintas (Cunha 2009).

\subsubsection{Cimento}

O material mais usado pela construção civil atualmente, o cimento é considerado por muitos o melhor material para camadas de cobertura para construções em clima frio ou chuvoso. Esta opinião não é partilhada pelos pesquisadores do LILD e autores especializados em construção com materiais naturais.

Snell \& Callahan (2009) e Guelberth \& Chiras (2009) concordam com as propriedades físicas dos materiais mas divergem do conceito de camada de cobertura. Segundo estes autores, a camada de cobertura deve ser permeável para permitir a entrada e a saída da umidade.

Materiais isolantes como o cimento e as tintas látex não permitem a entrada da água até determinado ponto. Mas como solvente universal a água sempre encontra um caminho para entrar e devido às propriedades de isolamento do cimento a umidade fica aprisionada em um local em que a sua presença contribui para a deterioração do barro e das fibras vegetais.

Segundo Rascusin \& McArleton (2012) outra desvantagem do cimento é o seu alto impacto socioambiental, o maior entre os materiais aqui apresentados, afinal as fábricas que produzem cimento são grande produtoras de gás carbônico $\left(\mathrm{CO}_{2}\right)$. Sua vantagem mesmo é a força estrutural especialmente misturado com fibras. 


\subsubsection{Cal hidratada}

Este é outro material que era amplamente usado na antiguidade e que hoje em dia seu uso diminuiu muito. Comparado a outros materiais é considerado o que tem melhor relação custo-benefício (Snell e Callahan 2009). Isto acontece por alguns fatores: sua capacidade mecânica só perde para o cimento; tem um custo socioambiental consideravelmente mais baixo (Rascusin e McArleton 2012), além de permitir que a "respiração" do barro e promove a permeabilidade do vapor d'água.

O calcário, matéria-prima da cal, é um produto obtido a partir dos fósseis de animais marinhos do período Pré-histórico. É possível obter a cal através do giz e de corais marinhos (Weismann and Bryce 2011) ou por meio de rochas sedimentares.

Há indícios de que a cal hidratada foi amplamente usada no período da Roma Antiga (Rascusin e McArleton 2012) principalmente nas fundações e na construção dos aquedutos. Mas os registros mais antigos do uso da cal como camada de cobertura encontram-se na cidade de Jericó (Palestina) e em TelRamad (Síria) ambas datadas do ano 7000 a.C. (Weismann and Bryce 2011). Weismann \& Bryce (2011) também mencionam que atualmente, com o crescimento da reflexão crítica sobre a durabilidade, proveniência e descarte dos materiais o uso da cal tem crescido pelas suas inúmeras propriedades.

Após a extração do calcário (carbonato de cálcio e carboneto de magnésio), este é aquecido acima de $1100^{\circ}$ Celsius para que se torne chamada cal virgem (óxido de cálcio e óxido de magnésio). Na etapa seguinte molha-se o material para que este se torne na cal hidratada (hidróxido de cálcio e hidróxido de magnésio). Ao secar o peróxido de cálcio retorna ao estado de calcário e para ser reutilizado precisa passar por todo o processo novamente. (Guelberth e Chiras 2009).

Quanto mais tempo a cal virgem for hidratada, melhor ficará a plasticidade e resistência do material. O tempo mínimo proposto é de 14 a 20 dias mas o ideal segundo Guelberth \& Chiras (2009), é pelo menos 3 meses de hidratação. Pedrotti (2006) diz que o tempo mínimo é de um ano, mas há relatos ainda mais longos. Snell \& Callahan (2009), mencionam que ouviram histórias dizendo que na Roma Antiga havia uma lei que dizia que a cal deveria ser hidratada por pelo menos 6 anos. Weismann \& Bryce (2011) contam que na Grâ-Bretanha havia normas de deixar a cal hidratando para que a geração seguinte pudesse usar. 
Como o processo de hidratação é lento, o de secagem acontece da mesma forma. Snell \& Callahan (2009) contam, e nossa experiência comprovou, a pasta de cal hidratada (pastacal como é chamada no LILD), deve ser hidratada antes e depois de ser aplicada, para aumentaar bastante o tempo de secagem, para evitar fissuras de retração por secagem rápida.

Snell \& Callahan (2009) falam que uma das piores características da cal hidratada é que se não for associada a fibras e areia e não houver uma secagem lenta ela tem a tendência a formar pequenas fissuras. Uma solução indicada, além da aplicação dos métodos e materiais mencionados, é o uso de uma esponja úmida com movimentos circulares para vedar as pequenas fissuras que surgirem. Minke (2009) aconselha a aplicação de camadas bem finas de pastacal diluída para que ela penetre melhor na superfície aplicada.

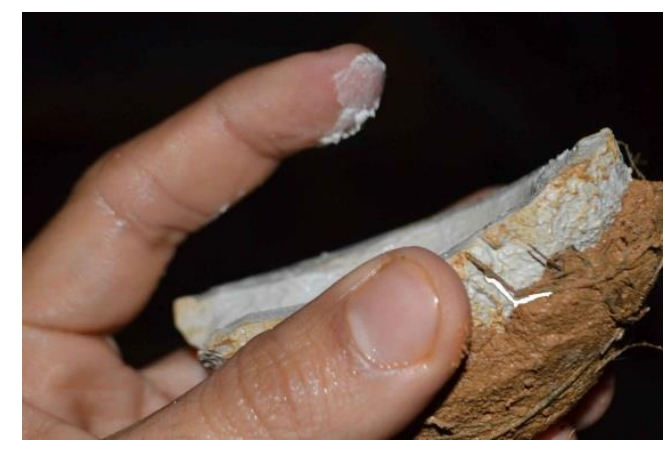

Figura 2 - Núcleo ainda úmido apesar do exterior já estar seco.

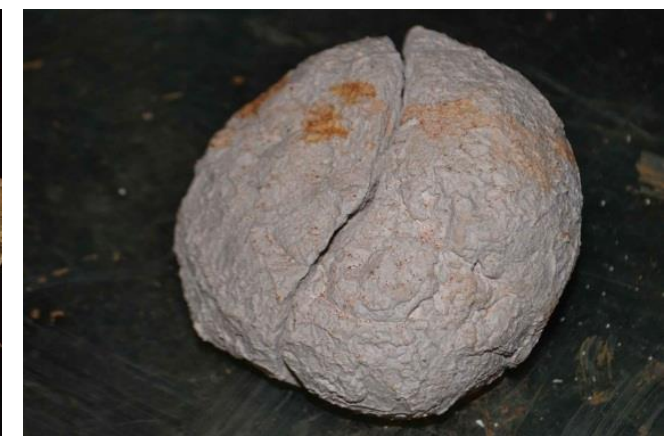

Figura 3 - Esfera maciça de pastacal seccionada depois de um mês secando

Sobre este tempo de secagem chegamos a fazer uma comprovação no LILD, apór um período de 3 meses hidratando $20 \mathrm{~kg}$ de cal, produzimos uma esfera macissa de pastacal com cerca de $8 \mathrm{~cm}$ de diâmetro. Após cerca de 30 dias quebramos a esfera de cal hidrata ao meio (Figura 3) e notamos que, apesar de a parte exterior estar seca, a parte interior ainda apresentava humidade (Figura 2). Principalmente mais próxima ao núcleo da esfera.

Outras características da cal que podem ser benéficas depois de aplicada é que ela é um agente fungicida. Além disso quando utilizada sem muitas misturas tem a coloração de branco muito forte o que, em teoria, é bom para ajudar a iluminar ambientes e funciona como isolante térmico por refletir raios solares. Também se adequa bem misturada a outros pigmentos podendo fazer tintas e acabamentos de outras cores. (Pedrotti 2006).

Weismann \& Bryce (2011) relatam que o material dificulta a propagação das chamas. Para exemplificar essa propriedade contam que após o incêndio 
que destruiu a London Bridge, o Rei João redigiu uma lei exigindo que todas as construções comérciais ao longo do rio Tâmisa fossem revestidas com cal por dentro e por fora.

No Brasil, Mendes, Veríssimo, \& Bittar (2010) mencionam que até o século XVIII a colonização portuguesa usava a mistura de cal e areia sobre as paredes de barro. Este reboco era coberto por uma caiação feita a partir da incineração de mariscos e conchas. Não fica claro se a cal usada no reboco tinha a mesma procedência, nem outros detalhes sobre de como era usada. Weismann \& Bryce (2011) relatam que praticamente toda cidade na Inglaterra produzia sua própria subsistência de cal a partir dos produtos locais. É plausível que no Brasil algo similar tenha ocorrido.

\subsection{Materiais de origem vegetal}

Em construções convencionais de terra crua tanto Snell \& Callahan (2009) e Guelberth \& Chiras (2009) aconselham o uso de fibras de comprimento entre 2,5 e $5 \mathrm{~cm}$ nas primeiras camadas e que estes tamanhos sejam diminuídos até que a camada final não possua fibra alguma. As fibras neste caso servem para aumentar a resistência mecânica do compósito.

Para proteger as construções da ação das intempéries os materiais de origem vegetal, apesar de beneficiarem as paredes, exigem uma manutenção mais constante do que os materiais de origem mineral. Contudo, seu uso não pode ser descartado principalmente em situações em que se busca o menor impacto socioambiental e há mão de obra disposta a efetuar a manutenção.

\subsubsection{Mucelagem de cactos}

Lengen (Lengen 2004) e Guelberth \& Chiras (2009) mencionam o uso de cactos para produzir uma mucelagem. Após um període 7 a 14 dias o cactos misturado com água fermenta e é usado como um aditivo para aumentar a resistência do barro, agindo como aglutinante.

Produzimos este experimento no LILD usando o cactos palma (Opuntia cochenillifera) Inicialmente os pedaços ficaram boiando na superfície do balde por alguns dias (Figura 4), cerca de 10 dias após o início do experimento notamos que os fragmentos de cactos cortados afundaram (Figura 5) e a partir deste dia notamos que o cheiro proveniente da mistura começou a ficar mais 
forte, principalmente quando a revirávamos. Refletimos se o fato dos pedaços da planta terem afundado não seria um indicativo de que a fermentação já havia atuado o suficiente para aplicarmos o líquido.

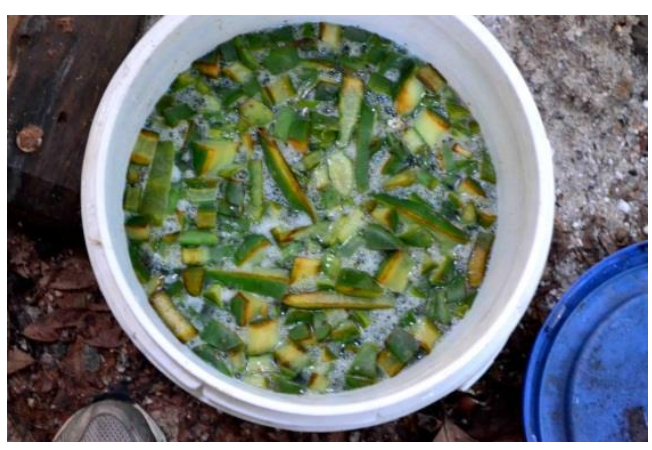

Figura 4 - Mucilagem com 2 dias de fermentação. Ainda é possível ver os pedaços de cactos na superfície.

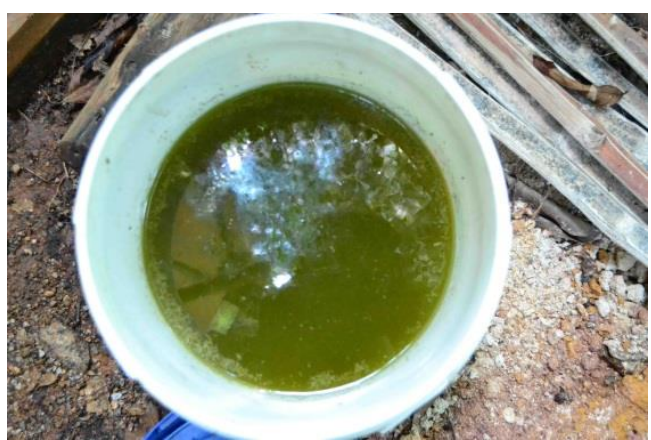

Figura 5 - Após 10 dias de fermentação as amostras foram para o fundo do balde

Apesar do cheiro forte, o que para algumas pessoas chegou a ser insuportável, a mistura foi coada com um pano de algodão e fizemos alguns testes que antes mesmo de serem aplicados nos surpreenderam. Sabíamos da capacidade aglutinante da mistura mas mesmo assim nos impressionou quando percebemos que era possível levantar a bacia na qual preparávamos a mistura apenas segurando a massa de barro com mucilagem (Figura 6).

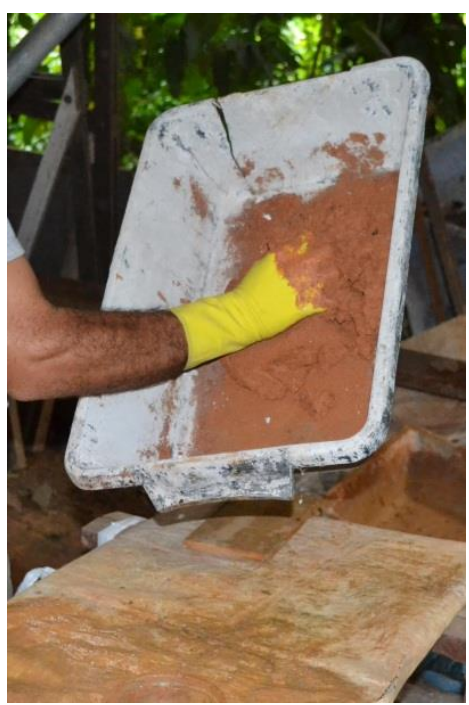

Figura 6 - Mistura de mucilagem de cactus com barro sendo levantado.

\subsection{2. Óleos}

Segundo Guelberth \& Chiras (2009) algumas sociedades misturam alguns tipos de óleos para aumentar a resistência à ação da água e a durabilidade do 
barro e de fibras vegetais. O mais indicado é o óleo de linhaça, mas os autores alertam que tais materiais só devem ser usados na camada final, para que o óleo possa reagir com o oxigênio. Assim o óleo fixa melhor na superfície e torna a camada final de cobertura mais flexível, aumentando a resistência à fissurações derivadas de ações climáticas.

Também é preciso haver cuidado em relação à proporção de óleo na mistura. Os autores afirmam que não pode ser superior a $5 \%$, devido a riscos de camada não aderir à estrutura. Pelo que foi possível apurar, apesar de aumentar a durabilidade da camada externa, se usado em demasia, o óleo pode reagir diferentemente da camada estrutural diante das mudanças climáticas e se separar da estrutura.Neste processo, a porosidade do óleo pode permitir a entrada de umidade. Outro fator que requer atenção é em relação à procedência e composição do óleo. Atualmente o óleo de linhaça comercializado é misturado a produtos tóxicos e poluentes.

\subsubsection{Mandioca e trigo}

Outros elementos que são sugeridos como camadas de cobertura é a massa de polvilho de mandioca azedo (Belanko in Marangoni, 2000) e farinha de trigo (Weismann \& Bryce, 2011). Ambos os processos podem ser feitos com água e fervidos para que o amido das substância reaja e forme uma gosma para adicionar ao composto. É aconselhado que a aplicação seja feita o mais rapidamente possível enquanto a gosma ainda não endureceu.

\subsubsection{Casca de arroz fermentada}

Já a Mesquita de Djenne, em Mali, uma das maiores e mais antigas construções de barro no mundo, anualmente recebe uma camada de arroz fermentado e barro. Com períodos de estiagem e chuvas bem definidos, as cascas da colheita de arroz são depositadas na lama do leito do rio que secou para fermentar. Antes do fim do período de estiagem a população da cidade faz uma competição para cobrir as paredes externas da mesquita (Figura 7) (Allen 2011). 


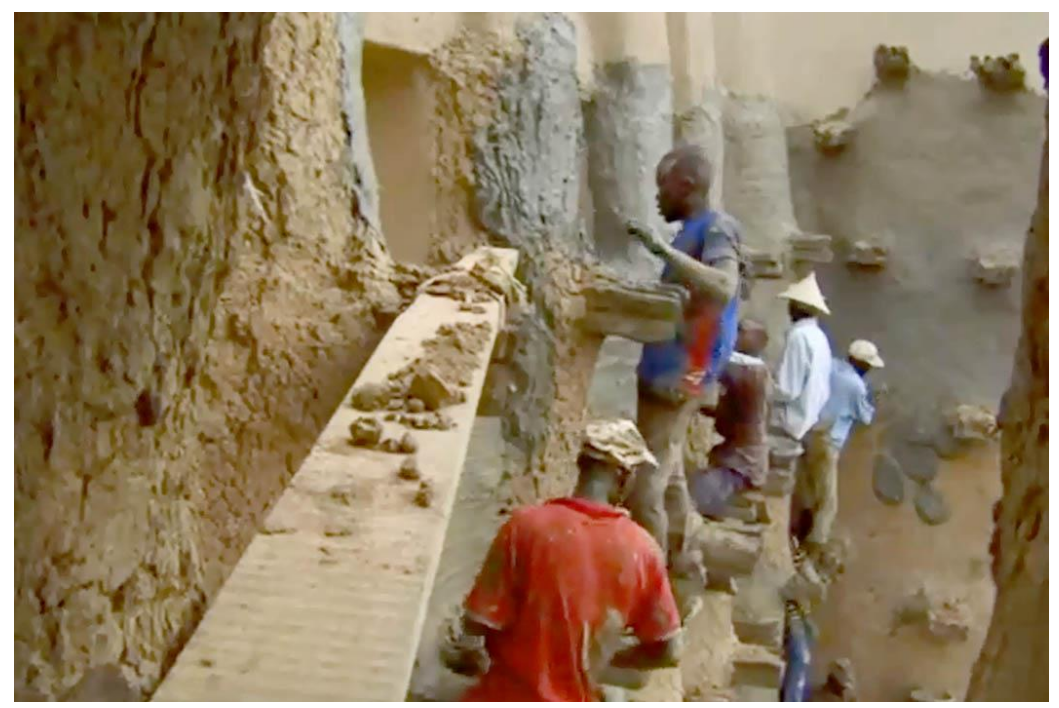

Figura 7 - Moradores da cidade cobrindo as paredes da mesquita de barro com casca de arroz fermentado. Fonte: (Allen, 2011)

É interessante observar no vídeo ${ }^{3}$ o aproveitamento dos movimentos naturais e cíclicos dos objetos e das estações. O barro é fornecido pelo leito do rio que secou. As fibras utilizadas são resquícios da colheita de arroz. Ambas ficam de misturadas ao resto de água do rio para atingirem o ponto da plasticidade requerida.

A aplicação é feita pelos moradores da cidade que dividem as suas tarefas de acordo com suas capacidades físicas. Com o uso de escadas e aproveitando os troncos de embutidos na construção, escalam as paredes para fazer a aplicação da camada de cobertura que ficará encarregada de proteger a mesquita pela estação de chuvas que se aproxima.

\subsection{Materiais de origem animal}

Mais fáceis de serem encontrados em ambientes rurais, os ingredientes de origem animal são considerados de extrema utilidade quando disponíveis. Estes materiais são mais um da lista de itens que funcionam melhor como aditivos para ajudar a promover a resistência dos materiais à ação da água das chuvas.

Proteína encontrada no leite, a caseína é um material que pode ser misturado para aumentar a resistência das camadas externas que tenham na cal um dos seus ingredientes. Belanko (Belanko 2000) a utiliza misturada com barro. Mas tanto Jorge Belanko assim como Weismann \& Bryce (2011) aconselham ser usada como componente da pintura devido ao seu valor comercial como

\footnotetext{
${ }^{3} \mathrm{http}: / /$ www.youtube.com/watch?v=Es1 meqd8SJ0
} 
alimento. No capítulo sobre experimentos no LILD mostraremos alguns experimentos que fizemos com a mistura de cal e caseína.

Minke (2009) também acredita que a caseína acrescentada à pintura de cal hidratada aumenta a durabilidade da mistura.Outro material que pode ser acrescentado a caseína é o borato de cálcio (bórax) para o caso de se preferir uma coloração mais escura.

O estrume animal também é outro material muito usado na produção de camadas de cobertura. Belanko (Belanko 2000) é um construtor que relata que o esterco de vaca se fermentado antes de utilizado, se torna a melhor camada de cobertura. Ele conta que, se deixado de molho por 7 a 10 dias, não há melhor material para fazer camada de cobertura.

Já Weismann \& Bryce (2011) não mencionam a necessidade da fermentação do esterco mas enfatizam que este deva ser usado fresco. Eles também diferenciam o esterco de vaca do esterco de cavalo. Segundo eles o de vacas é o melhor a ser usado e pode ser utilizado diretamente na mistura com o barro e os outros aditivos.

Já o estrume de cavalo é aconselhado por eles a serem peneirados para que as fibras presentes sejam testadas à parte. Segundo esses autores, o processo digestivo dos cavalos e o tipo de alimentação nem sempre beneficia os materiais o suficientemente.

Minke (2009) relata que na China Medieval era comum o acréscimo de ureia para aumentar a resistência da cal hidratada. Contudo não é explicado o princípio ativo ou se fizeram experimentos a respeito disso.

\subsection{Ferramentas e gestos no processo de construção}

As ferramentas utilizadas por todos os autores aqui citados utilizaram elementos comuns a qualquer construção convencional. Pelo que pudemos perceber, o que difere mesmo são os materiais utilizados.

Weismann \& Bryce (2011), por exemplo, primeiramente garantem que a camada de cobertura terá superfície de ancoragem. Para isso, promovem sulcos nas paredes ou deixam as fibras da camada anterior aparentes. Após esta primeira ação, dependo da situação, utilizam uma escova de cerdas macias para remover a poeira e, momentos antes da aplicação, hidratara a superfície com algum instrumento aspersor.

Segundo Snell \& Callahan (2009) e Guelberth \& Chiras (2009) as primeiras camadas podem ser aplicadas com as mãos pressionando o compósito na 
superfície receptora. A experiência pessoal indica que ferramentas como colher de pedreiro e desempenadeiras são mais apropriadas quando se busca um acabamento mais homogêneo e controlado. Em algumas situações, especialmente quando a área a trabalhar não for grande, Snell \& Callahan (2009) sugerem o uso de um objeto flexível como um cartão plástico, como um cartão de crédito, para facilitar a aplicação e o conserto de imperfeições.

Pelo que foi possível averiguar, pelos registros audiovisuais de Weismann \& Bryce (2011) e Guelberth \& Chiras (2009), a aplicação deve ser feita por meio de movimentos de parábola ou pressionando verticalmente o compósito. Em ambos os casos os autores aconselham começar da parte inferior e indo para a superior. Posteriormente à aplicação, Guelberth \& Chiras (2009) aconselham o uso de uma desempenadeira de madeira homogenizar a superfície.

Segundo Weismann \& Bryce (2011) os procedimentos de aumentar a área de contato, hidratar, aplicar, aparar, devem ser repetidos a cada camada colocada para que o resultado final tenha qualidade. As experiências práticas ensinaram, ao final de cada ciclo, a hidratar novamente a superfície para que o processo de secagem fosse o mais lento possível.

Após a aplicação estar concluída, estes autores recomendam também o uso de movimentos circulares utilizando ferramentas mais sutis como esponjas ou tecidos para fechar fissuras na superfície externa. Esta ação, juntamente à hidratação deve ser feita principalmente quando o material da camada final contiver cal ou argila, que tendem a fissurar quando a secagem não acontece de forma gradual.

Uma das vantagens destes tipos de materiais é a sua flexibilidade de usos. Ao longo da pesquisa dos vídeos, dos livros e das práticas foi possível observar pessoas de todos os tipos de idade e gênero participando das atividades de construir. Os operários das construções analisadas, longe de estarem posando para fotos, pareciam estar compenetrados e atentos ao seu fazer gestual e ao seu trabalho.

Em imagens como as dos garotos de Mali ajudando os mais velhos, os jovens (Allen 2011), aparentemente brincavam, enquanto os mais velhos que escalavam o prédio sem equipamentos de segurança para fazer o acabamento da Mesquita (Figura 7, página 41). Mesmo no curto vídeo foi possível perceber que toda a comunidade estava envolvida. 


\subsection{Alguns experimentos do LILD}

Ao longo de todos os anos de pesquisa aplicada em diferentes contextos socioambientais, o LILD é reconhecido mundialmente pelos seus estudos de buscar formas eficientes, aproveitando a potencialidade dos materiais utilizando a menor quantidade possível de recursos.

Apesar de ser mais conhecido pelo desenvolvimento de estruturas geodésicas construídas com bambus, alguns pesquisadores, ao longo dos anos, fizeram pesquisas utilizando também outras fibras vegetais e barro e métodos de protegê-los . Podem-se destacar as pesquisas de Côrtes (1999), Leme (Leme, Construção com "fibrosolo": um estudo de caso sobre o resgate da técnica de taipa, e seus efeitos no ambiente de clima tropical úmido com estação seca e chuvas de verão 2003) (Leme, O fibrosolo como pele para a construção: da tradição construtiva do homem do campo, aos espaços habitados pelo homem da cidade. Um conceito de aeração das moradias a partir da aplicação construtiva de cascas, placas e folhas de fibrosolo 2008), Xavier (2009), Alvares, (Alvares 2008), Campos, (Campos, Design de estruturas reticuladas de bambu geradas a partir de superfícies mínimas 2009) e Silva (Silva 2011) como referenciais das possibilidades de proteção, ação e metodologia.

Vale ressaltar que nas construções com técnicas tradicionais com barro cru é comum o uso dos pés e enxadas para misturar a água, o barro e as fibras (Côrtes 1999). Em alguns casos, quando os recursos estão disponíveis, preparase o barro com metodologia similar à do cimento: usando uma betoneira para homogeneizar a mistura barro e água, momentos antes de serem aplicadas.

A metodologia de uso de barro do LILD inclui a peneiração e hidratação do barro com pelo menos doze horas de antecedência, mas o ideal é trabalharmos com o barro hidratado por longos períodos (Leme, 2003). Também vale ressaltar que os alunos e pesquisadores aplicam as técnicas de trabalho entre aulas e outros compromissos e com isso diminui o tempo de trabalho devido à necessidade de limpeza do espaço e do corpo.

Tudo isso associado à técnica de se utilizar grande volume de fibras na manufatura dos compósitos, beneficia o uso de técnicas manuais para a mistura de barro e fibras, como visto em Silva (2011) (Figura 8). Com isso a mistura de fibras ao barro acontece de maneira mais lenta, mas com um controle maior, se for considerado que a quantidade de fibras utilizadas na mistura é elevado. 


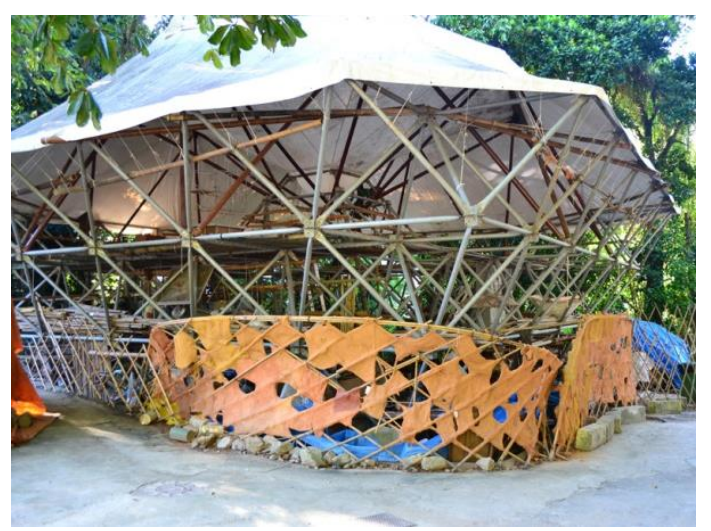

Figura 8- LILD - PUC-Rio. Em abril de 2011. Parede externa do LILD. Treliça de bambu coberta por argila e fibras e tecidos de fibras naturais.

Seixas (Seixas 2009) e Campos (2009) desenvolveram pesquisas de uso de lonas têxteis sobre estruturas de bambu. Esta ação não é diretamente sobre os materiais mas cria uma área de preservação que inclusive atua como proteção a ação direta da chuva. Um exemplo disto é a estrutura de lona do LILD (Campos, Design de estruturas reticuladas de bambu geradas a partir de superfícies mínimas 2009) que protegia parcialmente o muro de fibrobarro que Silva (2011) pesquisou (Figura 7, página 41).

\subsubsection{Fibras experimentadas}

O fibrobarro é uma metodologia desenvovida inicialmente por Leme (2003) para realizar construções com barro utilizando o mínimo de material possível mas aproveitando ao máximo as formas. A pesquisa chegou a produzir cascas e mantas de fibrobarro quando associada a tecidos.

Alguns pesquisadores desenvolveram trabalhos utilizando diferentes qualidades de fibras. Nos primeiros ensaios do fibrobarro realizados por Leme (2003) na pesquisa de campo na cidade de Monteiro (MG), utilizou-se as fibras disponíveis na localidade. Nos experimentos do LILD (RJ), deu-se preferência para fibras naturais disponíveis: folhas de bambu e sisal. Em Leme (2008) buscou-se utilizar outros recursos disponíveis comercialmente sem produtos químicos imbutidos, como o algodão e o coco. Silva (2011) fez experimentos com outras fibras como bagaço de cana, fibras de bananeiras, rami e algumas outras espécies. Algumas mostraram-se promissoras como as fibras de coco, mas outras, como a cana, não deram resultados muito animadores por terem mofado ou mostraram-se pouco aderentes ao barro.

Em 2011, quando esta pesquisa se iniciou, o uso de tecidos de algodão misturados com barro não estavam sendo recomendados pelos pesquisadores da época porque, com as variações de umidade com que o barro trabalha, o 
algodão, na maioria dos casos, apodrecia, perdendo assim suas propriedade mecânicas. A única exceção aconteceu quando o algodão foi coberto com resinas.

\subsubsection{Camadas de cobertura para proteção}

Dentre os materiais utilizados para proteger tanto o bambu quanto 0 fibrobarro devemos destacar o uso da resina de mamona. De origem vegetal, este polímero tem sido experimentado no LILD como proteção do fibrobarro e do bambu às intempéries.

Campos (2009) menciona o uso da resina como camada de cobertura em bambus revestidos com diferentes materiais naturais com diferentes combinações. Entre eles podemos mencionar o barro, a areia e os tecidos de algodão (gaze). Esta técnica foi chamada de encapsulamento pois seu princípio é isolar os bambus dos seus agentes erosivos. Atualmente, este conceito de proteção está sendo revisto porque alguns dos bambus que receberam a camada de resina estão contaminados pelo inseto Chlorophorus annularis, popularmente conhecido como tigre.

Alvares (2008) e Leme (2008) construíram uma cúpula de fibrobarro composto de fibras de sisal muito longas. Esta cúpula foi coberta por resina de mamona. Na ocasião foi aberto um círculo de $70 \mathrm{~cm}$ de diâmetro para servir de entrada para o interior. $\mathrm{E}$ o fato mais surpreendente foi notado justamente nessa circunferência. Do lado que não recebeu a cobertura o barro saiu completamente. Percebemos que onde a resina tocou no compósito este se tornou um material diferente dos seus componentes.

Outro material muito usado pelos os pesquisadores do laboratório foi a cola PVA. O primeiro registro de uso da cola misturada ao barro é de Côrtes (1999), mas Leme (2003 e 2008) e (Xavier, 2009) foram pesquisadores que procuraram comprovar a capacidade protetora da cola em relação ao contato com a água.

\subsection{Inferências}

Pode-se dizer que autores como Soares (2001) e Guelberth \& Chiras (2009) concordam que quanto mais diversificada for a camada da cobertura mais resistente e benéfico para a construção será. Snell \& Callahan (2009), comentam também sobre as vantagens de se ter mais de um tipo de camada, 
mesmo com materiais, como forma de aumentar a resistência da camada de cobertura. A questão da permeabilidade é um consenso para garantir uma durabilidade estrutural.

Ao verificar o relato dos pesquisadores do LILD, foi possível notar, que o conceito de superfícies mínimas também é refletido nos experimentos de camadas de cobertura. Os materiais e as formas são pesquisados buscando-se o aproveitamento máximo das suas características. As lonas têxteis de Seixas (2009) e Campos (2009) foram projetadas para ficar sobre estruturas que cobriam grandes áreas. As camadas de cobertura, as lonas, tinham uma espessura mínima em relação às áreas que estas cobriam.

Outro exemplo foi quando Alvares (2008) e Leme (2008) ao usarem a resina de mamona como cobertura para o casulo de fibrobarro. Mais uma vez notamos a utilização do mínimo de um material, no caso a resina, para proteger a estrutura.

Autores como Guelberth \& Chiras (2009), Minke (2009), Pedrotti (2006), Rascusin \& McArleton (2012) e Snell \& Callahan (2009) elegem a cal hidratada como o principal material para acabamento ou dedicam pelo menos boa parte dos seus trabalhos para mencionar as possibilidades deste material. A cal hidratada deveria ser mais estudada para que pudéssemos nos apropriar do seu manuseio e das suas características. Leme (2003 e 2008) e (Xavier 2009) chegaram a experimentar, mas em 2011 o uso ainda não havia sido apropriado pela equipe. 


\section{Experimentos feitos no LILD}

Toda pesquisa experimental tem como prerrogativa os experimentos em laboratório. Nossa intenção ao realizarmos os experimentos no LILD teve como principais justificativas a apropriação da técnica, dos materiais utilizados além de ter servido como primeiro contato com a metodologia do laboratório. Esta fase inicial também foi de extrema importância para o estabelecimento de vínculo com os outros pesquisadores do laboratório, algo essencial para o desenvolvimento aprofundado da pesquisa.

As reflexões feitas a partir das pesquisas em laboratório permitem um aprofundamento na relação dos materiais e dos gestos, diferente da experimentação do campo onde diversos fatores podem atuar simultaneamente interferindo na análise do que está sendo feito. No laboratório o controle destes parâmetros é um pouco maior.

Neste capítulo é descrito os experimentos realizados em corpos de prova dentro do LILD. Basicamente podemos dizer que os experimentos tiveram três etapas: Os primeiros experimentos foram feitos para apropriação das particularidades da argila, areia, fibras naturais e das técnicas empregadas no LILD; Na segunda etapa, foram feitos testes de aplicação de diferentes camadas de cobertura variando método de aplicação e materiais; Na terceira etapa, foi a oportunidade de testar empiricamente a resistência dos corpos de prova em relação à passagem de ar e à durabilidade frente à exposição à água.

A intenção com os experimentos, alguns deles repetidos por outros autores aqui descritos, encontram fundamento no trabalho desenvolvido por Janet Wolff (Woff 1982) que considera que o pensamento e consciência têm origem na atividade material e na capacidade do homem de refletir. Esta autora também tem uma opinião compartilhada por todos que passam pelo LILD: a consciência surge a partir da atividade prática reflexiva. Ela é a mola mestra para as verdadeiras mudanças e transformações.

\subsection{Corpos de prova de terra crua: um teste de fibras e proporções}

Para conhecer e pesquisar as possíveis camadas de cobertura foi preciso entender um pouco mais sobre o assunto que abordando. Principalmente em 
relação aos gestos e observações de detalhes que não são abordados nos livros, composto de formas estáticas. Nos trabalhos de campo nem sempre é possível voltar e repetir determinada ação e outros parâmetros interferiu. Nesta parte é relatado os primeiros experimentos feitos, suas análises e as hipóteses criadas a partir do que foi observado, sentido e refletido. É importante enfatizar que estes experimentos, apesar de terem começado um pouco antes, foram realizados quase que simultaneamente à aplicação da pesquisa no campo. Assim, ambos foram mutuamente influenciados e enriquecidos com dados e aprendizados.

Construções com materiais biocompatíveis fazem parte da história da humanidade, mas sua prática saiu do cotidiano de grande parte da civilização ocidental. E mesmo aqueles que ainda utilizam os métodos consagrados por nossos ancestrais o fazem sem muitas alterações nos métodos e nas formas de construir. Neste ponto a pesquisa do LILD em fibrobarro é inovadora por buscar formas e métodos que ultrapassam os padrões tradicionais. Também é importante ressaltar que nem sempre poderíamos trabalhar com terra bem argilosa ou somente com fibras de alto desempenho. Com isso, foi de extrema importância pesquisar outras combinações para averiguar algumas possibilidades de combinações de argila, fibras e outros materiais.

Como corpos de prova, foram produzidas superfícies curvas e esféricas, que possibilitaram mais de um tipo de teste de capeamento. Também foram produzidas esferas para possibilitar a reprodução de outros testes de permeabilidade. Além disso, segundo o Prof. Ripper, ao produzirmos superfícies curvas seria mais fácil de encontrá-las no ambiente, do que se fossem placas planas. Outro pré-requisito para a produção de esferas era a de que estas tivessem a mesma espessura como padrão para comparação.

\subsubsection{Testes de aplicação sobre tecidos}

A primeira tentativa para a produção de corpos de prova foi usando tecidos. Apesar da rapidez para cobrir grandes áreas homogeneamente com espessura mínima estes experimentos apresentaram alguns desafios, principalmente porque o objetivo era o de produzir cascas. Foram testados diferentes tecidos e tramas impregnando barro.

Inicialmente foi experimentado tecido de fibras de juta (Corchorus capsularis) que depois de impregnado com solo argiloso seriam aplicados sobre moldes. Esta pesquisa já acontecia no LILD mas, era possível encontrar 
referência anterior nos encontrar referências na pesquisa de Leme (2008).o professor Fernando Betim (Leme, 2008).

A aplicação do barro sobre o tecido (Figura 10 e Figura ) foi feita com gestos manuais sobre uma plataforma plana. Após a mistura a manta era aplicada sobre o molde e ficava em repouso até que a argila secasse o que ocorria em cerca de dois dias. Este tempo variava de acordo com o clima.

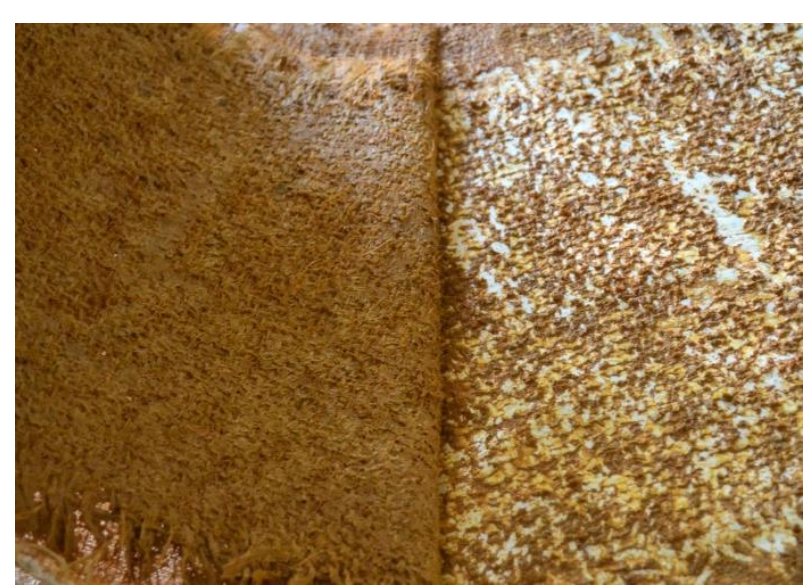

Figura 10 - Tecido de juta, depois da aplicação de solo, sendo retirado da mesa.

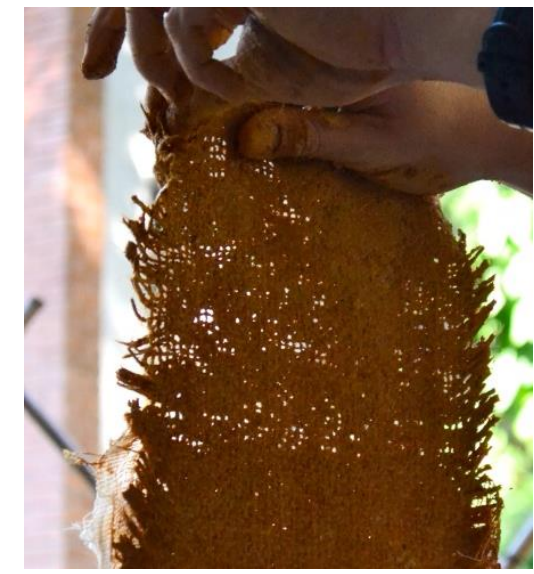

Figura 9 -. Tecido exposto

O primeiro experimento foi feito sobre um molde de gesso. Contudo, logo se percebeu que seria mais eficiente utilizar outra superfície de molde.

Essa conclusão deveu-se a não termos outras fôrmas o que dificultaria a produção de muitas amostras em pouco tempo.

Observamos que o tecido foi algo que também, inicialmente descartamos devido aos espaçamentos entre os fios de tecidos disponíveis não era suficiente espaçado desfavorecendo a união tecido-barro. Agregar outros tipos de fibras também foi outro desafio já que o espaçamento era reduzido.

Inferiu-se que solo poderia ter aderido mais eficientemente se houvesse um espaçamento maior entre as fibras. Outra opção seria se houvesse mais pressão na ação de unir o tecido ao barro por um período de tempo maior.

Os modelos produzidos assumiam as formas dos moldes, mas nas regiões de borda não apresentavam estabilidade (Figura 11). Esta instabilidade do modelo crescia ao longo do tempo até que a estrutura ficasse quase amorfa. Uma possível solução seria a aplicação de mais camadas de tecidos com solo que, unidas, poderiam fornecer mais estabilidade. Inicialmente imaginamos que esta união deveria ser feita com mais pressão por um tempo maior para a maior integração entre as camadas. 


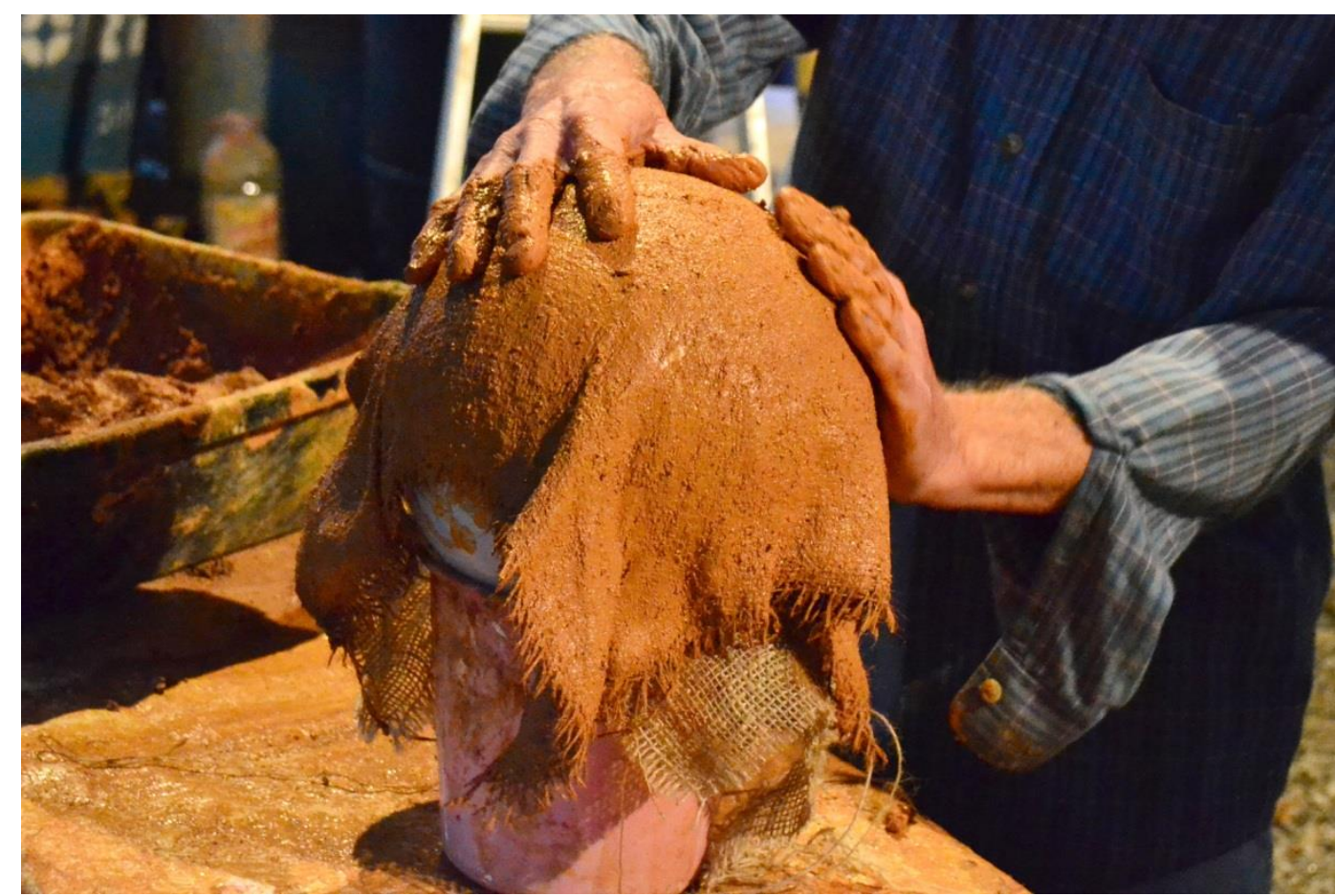

Figura 11 - Aplicação de solo sobre tecido em molde curvo.

Outro desafio encontrado foi atender as especificidades dos tipos de tecidos. Na maioria dos testes de aplicação de barro em tecidos que continham fibras sintéticas a aderência do barro não a mesma. Provavelmente isto aconteceu pelos tecidos sintéticos terem um número muito menor de reentrâncias, e cavidades em seus fios contribuindo assim para terem menor área de contato para adesão com a argila. A única exceção que encontramos aconteceu em experimentos feitos cerca de um ano e meio depois da pesquisa ter sido iniciada.

As aplicações de compósitos de juta-barro sobre estruturas de bambu aderência necessárias para unir-se à estrutura. Este modelo foi deixado de lado por um bom tempo. A pesquisa com o compósito de tecido-barro só foi retomada quando na ocasião da construção do telhado da espiral de bambu que foi construída em Cachoeiras de Macacu (RJ).

Algo que se deve destacar nesta técnica de misturar tecido ao barro tem relação aos gestos necessários. Ao contrário das técnicas tradicionais de trabalhar como o pau-a-pique ou a taipa de pilão, neste tipo de aplicação o controle da quantidade de barro inserida é grande. A inserção do barro no tecido requer gestos igualmente firmes, mas ao mesmo tempo é necessário pressionar para que o barro penetre nos espaços entre os tecidos. As pontas dos dedos foram muito utilizadas para intensificar a união tecido-barro (Figura 12). Antes de aplicar o compósito é recomendada a retirada do excesso de barro (Figura 13) 
para que este não se desprenda ou aumente 0 peso da estrutura desnecessariamente.

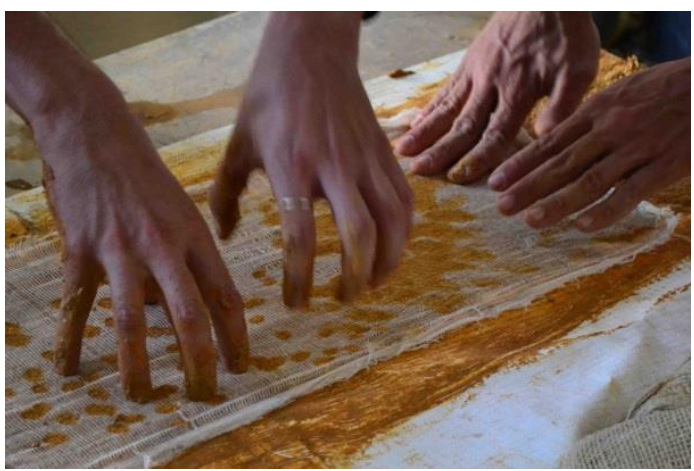

Figura 12 - Dedos pressionando o tecido para fixar no barro

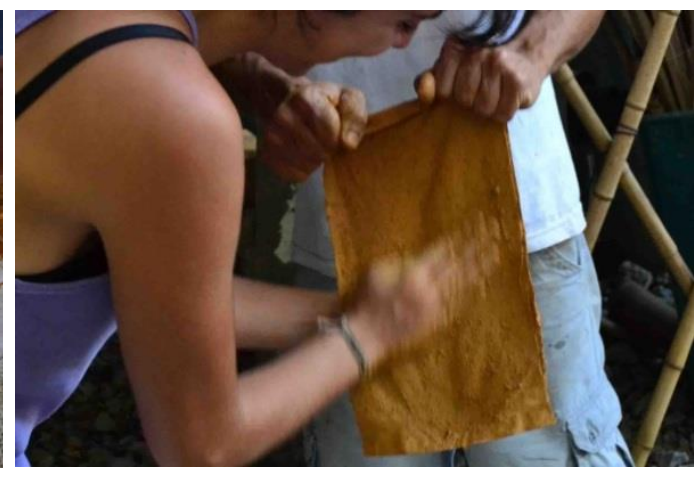

Figura 13 - Retirada do excesso

Quando os experimentos com laminados voltaram a ser produzidos, experimentamos corpos de prova com tecidos (Figura 12). Foram utilizadas fibras naturais já experimentas, juta de $5 \mathrm{~mm}$ de espaçamento, algodão alvejado de $2 \mathrm{~mm}$, e feltro (Figura 15).

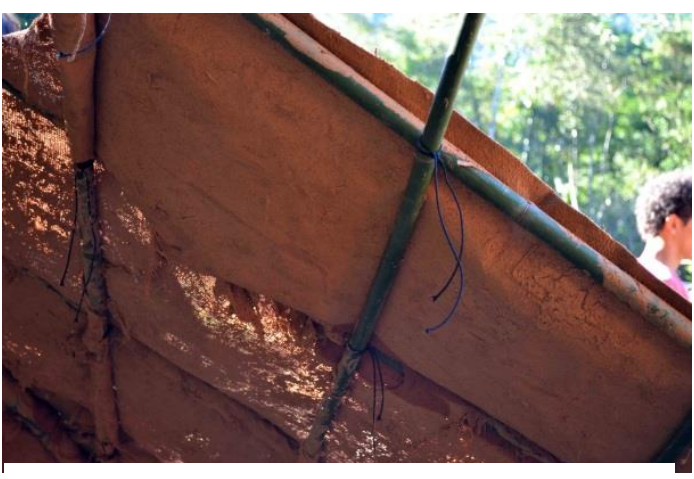

Figura 15 - Compósitos de juta-

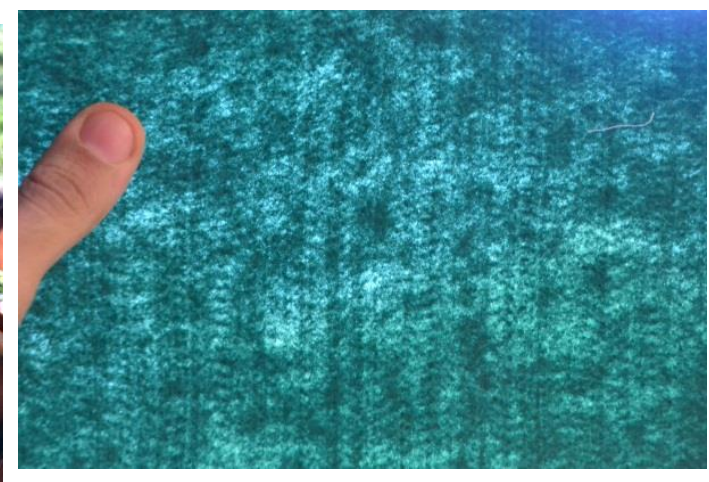

Figura 14- Feltro exposto contraluz barro e de feltro barro colocadas

\section{sobre estrutura}

A ideia de se utilizar o feltro surgiu a partir de uma oficina de fibrobarro feita em Cachoeiras de Macacu, RJ. Em determinado ponto da oficina acabaram as mantas de juta e a solução encontrada foi aplicação do feltro coberto de barro (Figura 14), com resultado satisfatório.

A técnica utilizada para capeamento dos tecidos foi estica-los de maneira que ficassem tensionados. Para isso foram utilizamos aros para bordado ou grampos sobre uma moldura (Figura 16). Foram testados tecido de algodão (pano de chão de $1 \mathrm{~mm}$ de espaçamento), juta de $5 \mathrm{~mm}$, algodão de $2 \mathrm{~mm}$ e o feltro. A aplicação de barro foi feita usando gestos manuais. 
A aplicação de fibras de grama no compósito (Figura ) não foi satisfatória pelo baixo entrelaçamento entre o tecido e as fibras..

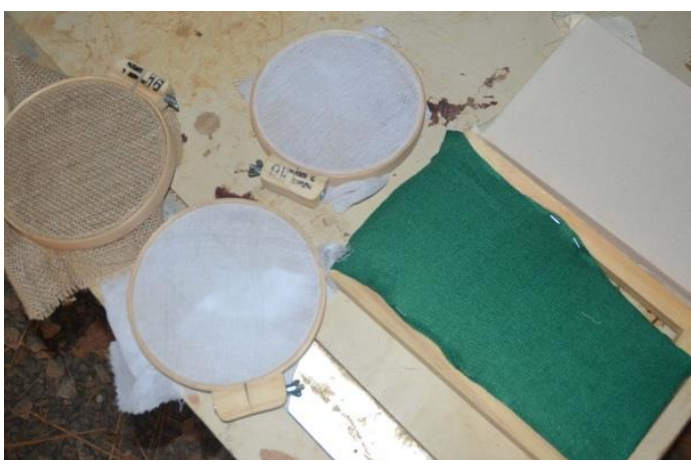

Figura 17 - Tecidos de fibras naturais e de feltro (verde) esticados em molduras.

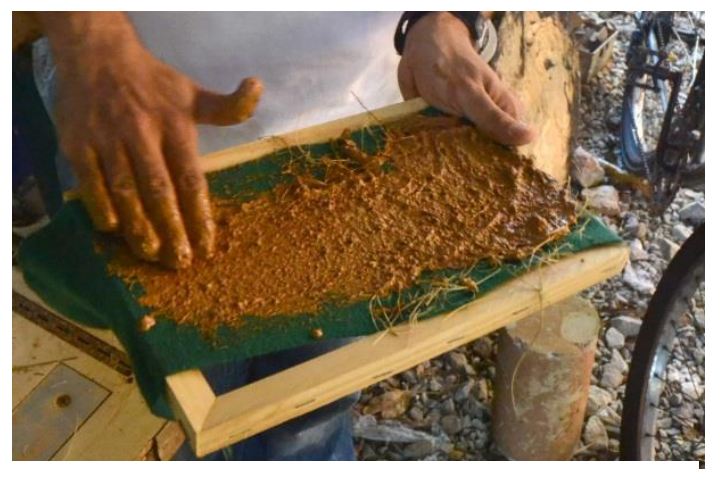

Figura 16 - Aplicação sobre tecido com e sem fibras adicionais.

O tecido de algodão cru de trama bem fechada não transpassou barro para o lado oposto, que se manteve quase intacto. Todos os tecidos testados apresentaram certa rigidez depois da secagem. Um dos primeiros testes de laminação foi feito com gaze industrial de trama $2 \mathrm{~mm}$ porque esta apresentou melhor aparência de integração quando aplicamos mais uma camada (Figura 19 e 19). Em termos de custos e de peso, o tecido de algodão tem um valor de mercado bem inferior ao tecido de juta, além do tecido de algodão ser facilmente encontrável no Rio de Janeiro.

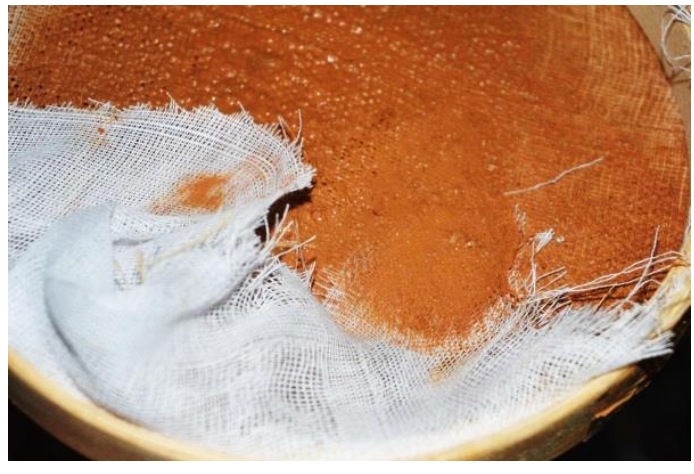

Figura 19 - Tecido de algodão Figura 18 - Tecido de juta

sobreposto. A segunda camada sobreposto.

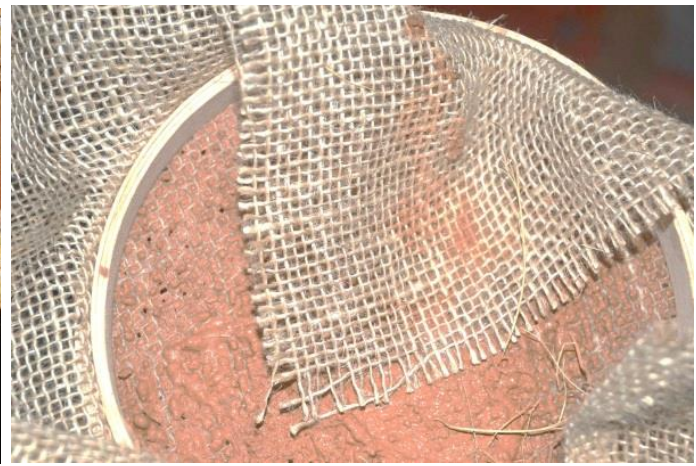
chega a desaparecer visualmente.

Para a construção da semiesfera laminada usamos como molde uma forma de gesso e aplicamos os retalhos de tecido alternadamente entre os que haviam sido embebidos com barro e foram aplicados limpos. Para assegurar a 
laminação pressionamos com os dedos (Figura 21 ) as duas camadas e também usamos um rolete de discos de acrílico para auxiliar na feltragem das

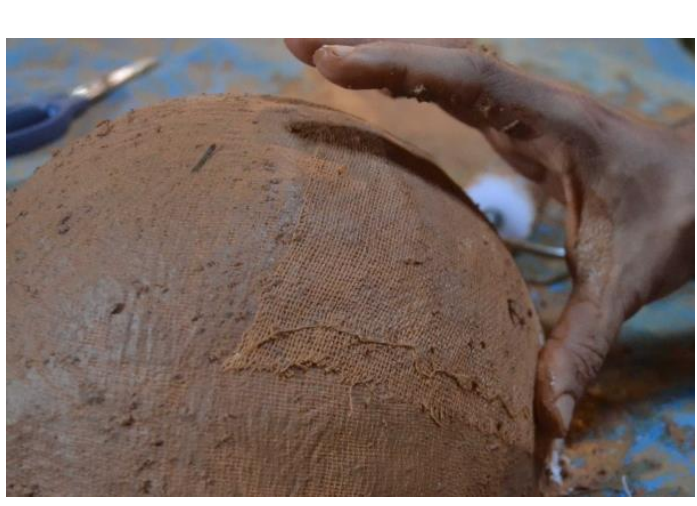
camadas (Figura 21 ).

Figura 21 - Pressionando as camadas com as mãos

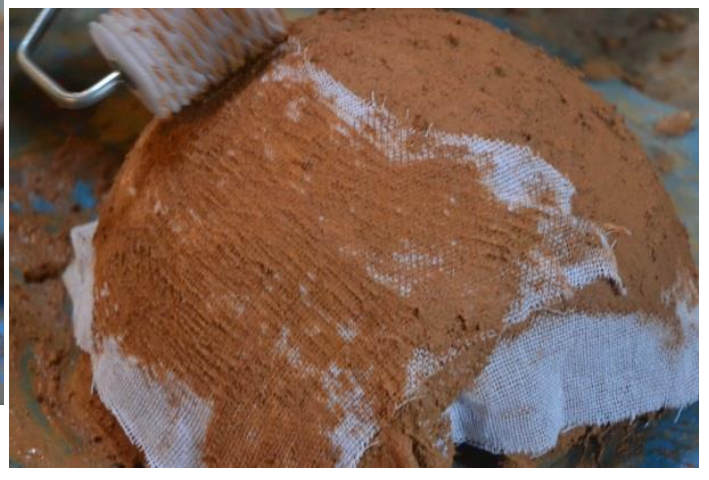

Figura 20 - Usando o rolete

Com cerca de 3 a 5 camadas e dois dias de secagem em tempo bem quente e úmido o corpo de prova manteve-se coeso e rígido (Figura 22). Para assegurar a forma, na borda utilizamos uma corda de sisal que foi envolvida pelas lâminas no processo de fabricação. A espessura final ficou em média de 3 a $4 \mathrm{~mm}$. Em outro corpo de prova substitui-se o barro pela cal hidratada e o resultado inicial foi muito parecido. O mesmo tipo de experimento foi realizado com feltro e com tecido de juta laminado. A casca de feltro não foi possível ser executada pela falta de aderência entre as camadas. Este funcionou melhor como camada única.

A casca laminada de juta apresentou características semelhantes ao do tecido de algodão. As diferenças foram a espessura do tecido e a maior quantidade de argila utilizada. O compósito laminado era sensivelmente mais pesado. A laminação de tecidos indicou pode ser uma solução eficiente em situações onde houver abundância de tecidos ou a necessidade de camadas extremamente finas.

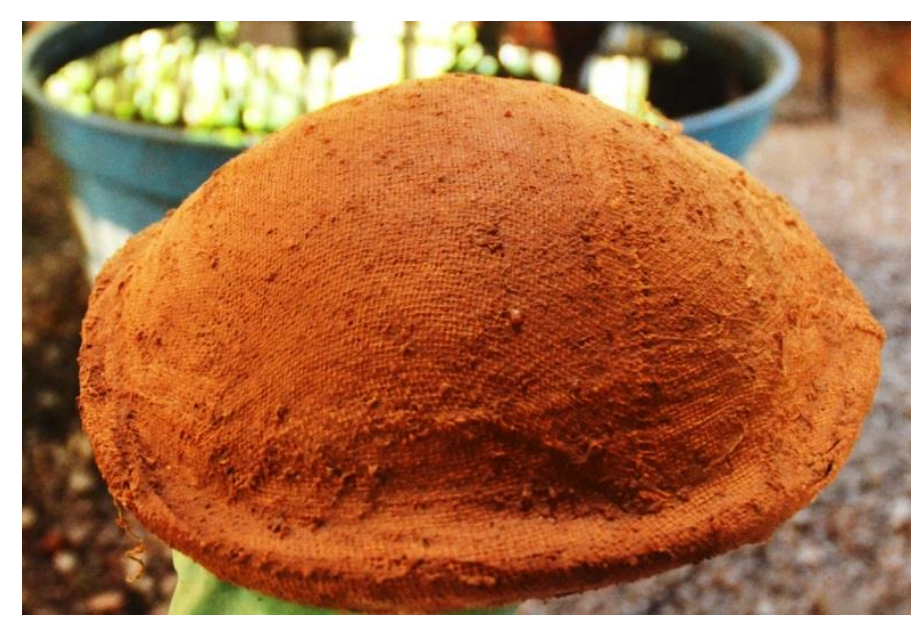




\section{Figura 22 - Casca laminada de tecido de algodão e barro}

\subsubsection{Esferas de fibrobarro}

Durante o desenvolvimento da pesquisa, foram desenvolvidas chapas de fibrobarro que serviram como suporte para experimentos de capeamento. Além disso, experimentar diferentes razões de fibras e areia e barro na construção de compósitos atendo-se à interação dos componentes e aos movimentos de fabricação apropriados. Nesta secção será relatado alguns experimentos feitos nesse sentido.

Para a fabricação das chapas foi utilizado, como molde, bolas de vinil, popularmente conhecidas como bolas dente de leite, de $25 \mathrm{~cm}$ de diâmetro. Por terem um custo reduzido e uma ampla disponibilidade, tal artefato permitiu a confecção de esferas quase completas em quantidade suficientemente rápida. Foi deixado um espaço de cerca $10 \mathrm{~cm}$ de diâmetro para recolher a esfera depois de esvaziada de ar.

Para dar mais homogeneidade à espessura dos primeiros corpos de prova, contamos com a experiência dos pesquisadores do LILD que ajudaram a estabelecer procedimentos gestuais usando água, batentes de madeira e rolo compressor de PVC (Figura 23). Assim, foi possível a produção de diferentes corpos de prova com espessura regular. Em outro momento da pesquisa o rolo foi substituído por um batente de madeira. Foi percebido que o rolo de PVC auxiliava na extração das fibras do compósito.

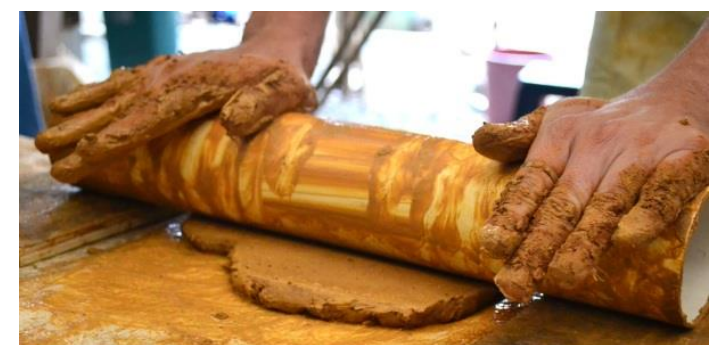

Figura 23 - Rolo de pvc e batentes de madeira ajudaram a formar chapas de espessura controlada.

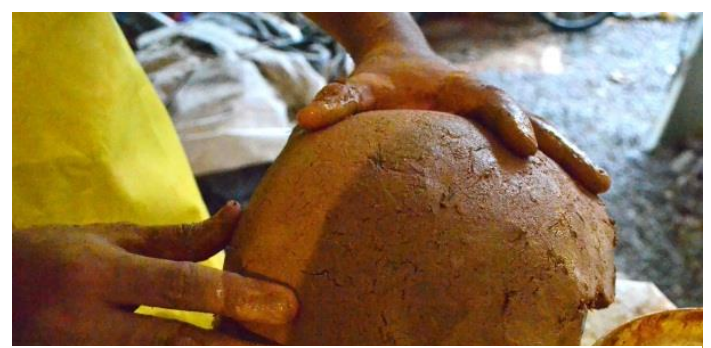

Figura 24 - Junção de placas sobre molde de vinil para a construção de esferas ocas

Durante a fabricação das esferas e outros corpos de prova tentamos produzir chapas maiores dimensões para evitar uni-las (Figura 24), procedimento que interferiu na espessura final mas apesar da nossa habilidade ter aumentado com a experiência, O tamanho das chapas não pode ser maior do que uma folha 
A4, pois o tamanho excessivo fazia com que a chapa fosse difícil de ser manuseada e se desfazia antes de termos terminado de aplicar o fibrobarro no molde.

A produção de chapas maiores foi possível usando fibras mais longas (cerca $20 \mathrm{~cm}$ no mínimo). A partir da contínua experimentação desta técnica, incluindo laboratórios de campo, também passou-se utilizar sacos plásticos ou de polipropileno flexível, com cerca de um metro quadrado, como suporte para aplicação do compósito solo-fibras. Também foi perceptível que, dependendo da fibra utilizada, a espessura do batente, cerca de $1,5 \mathrm{~cm}$, parecia ser mais fácil de ser obtida podendo até ser diminuída, pois menores espessuras também conduziram a bons resultados

Quando iniciamos os testes das camadas de capeamento, percebeu-se que as esferas não eram eficientes para receber capeamentos muito grossos. 0 molde reagiu à contração das camadas de capeamento superfície rachando o material. A solução encontrada foi a produção de chapas com curvatura mais aberta.

\subsection{Fibras naturais}

Dentre os aprendizados na produção das esferas podemos destacar a importância das fibras na construção com terra crua. Nos primeiros testes utilizamos a quantidade de fibras nos moldes do LILD: a imersão de fibras ao máximo de saturação possível. Este método foi inspirado no fiberglass.. Inicialmente, foram realizados testes com diferentes concentrações de fibras (

25).

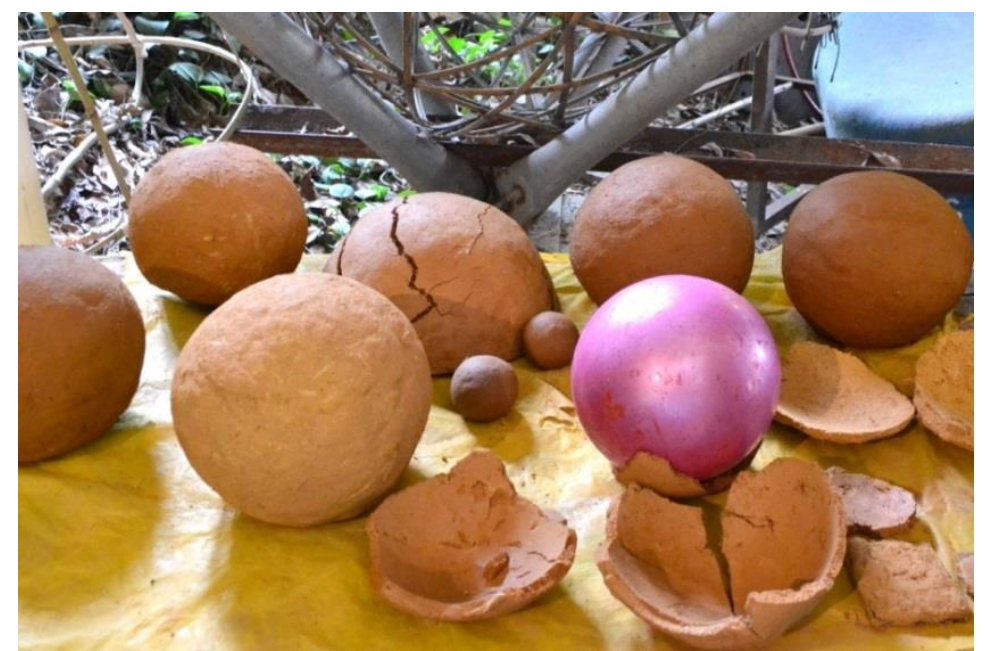


Figura 25 - Esferas e placas curvas com diferentes tipos de fibras e quantidades. A esfera sem fibras partiu-se completa-mente deixando o molde a mostra.

O uso das fibras é um elemento que pode dar a leveza aos compósitos (Manzini e Velozzi 2002). O fibrobarro é um exemplo do quanto pode se diminuir o peso, não só físico mas também visual, das construções de terra crua.

As experiências prévias, sucessivamente aproximativas conduziram a questionar sobre a quantidade mínima de fibras e sobre as espécies mais adequadas. Isto aconteceu tanto nos laboratórios de campo como no LILD, onde foram experimentados diferentes tipos de fibras em quantidades igualmente diferentes. A disponibilidade do campus da PUC-Rio e a convivência com as distintas realidades dos laboratórios de campo (Horta do Jardim Anil, na zona oeste da cidade do Rio de Janeiro e a propriedade rural em Cachoeiras de Macacu,) fizeram com que descobríssemos outras fibras além do sisal e das folhas de bambu.

O bioconstrutor Soares (Soares, 2001) relatou que as fibras mais interessantes para a construção são as ricas em sílica. Plantas ricas nessa substância possuem uma boa resistência à tração e, quando isoladas do contato com o ar, não se decompõem podendo resistir por muitos anos.

A pesquisa, ao longo do seu desenvolvimento, atuou em realidades sem acesso às fibras naturais já consagradas. O convívio com as pessoas do local sobre as propriedades que eram almejadas, estimulou a utilização de folhas de uricana (Palmeira de Mata Atlântica da espécie Geonoma rubescen) (Figura 26) e grama estrelada (Cynodon). 


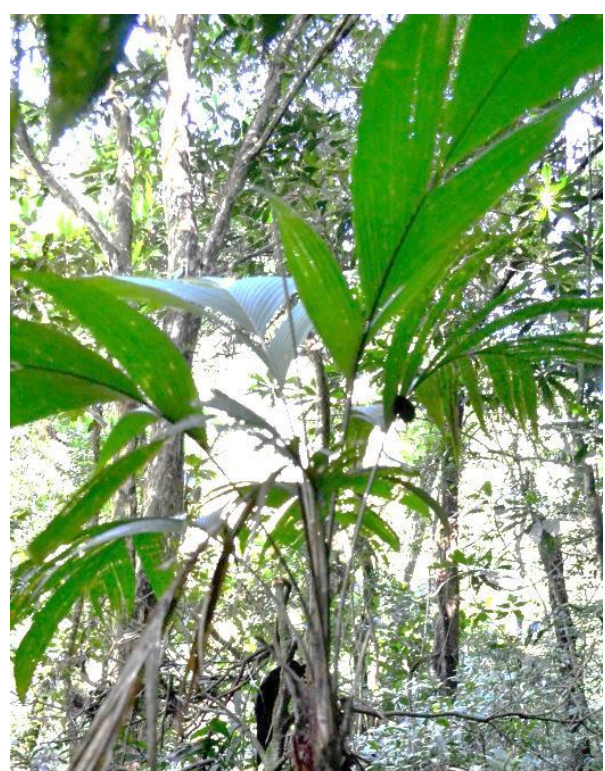

Figura 26 - Palmeira uricana

O manuseio de fibras de diferentes origens e resistências à tração, estabeleceu um padrão para sinalizar a quantidade de fibras mínima para uso. Autores como Khalili (2005) e Minke (1994 e 2009) não estabelecem a quantidade mínima, ou máxima, de fibras nem ampliam muitos sobre as espécies possíveis.

Segundo José Roberto d'Almeida (d'Almeida 2009), professor de Engenharia de materiais compósitos da PUC-Rio, usualmente na indústria trabalha-se com $30 \%$ a $60 \%$ de fibras. Em alguns casos o aproveitamento máximo do potencial das fibras chega a $90 \%$. Nos compósitos com o máximo de fibras possíveis, muito similar ao método do LILD, a matriz (no caso a argila) assume o papel de filme tendo comportamento quase idêntico ao reforço (as fibras). É importante ressaltar que, segundo a micromecânica, neste modelo o compósito tem muita resistência à tração axial mas, pouca nos sentidos transversal às fibras. 


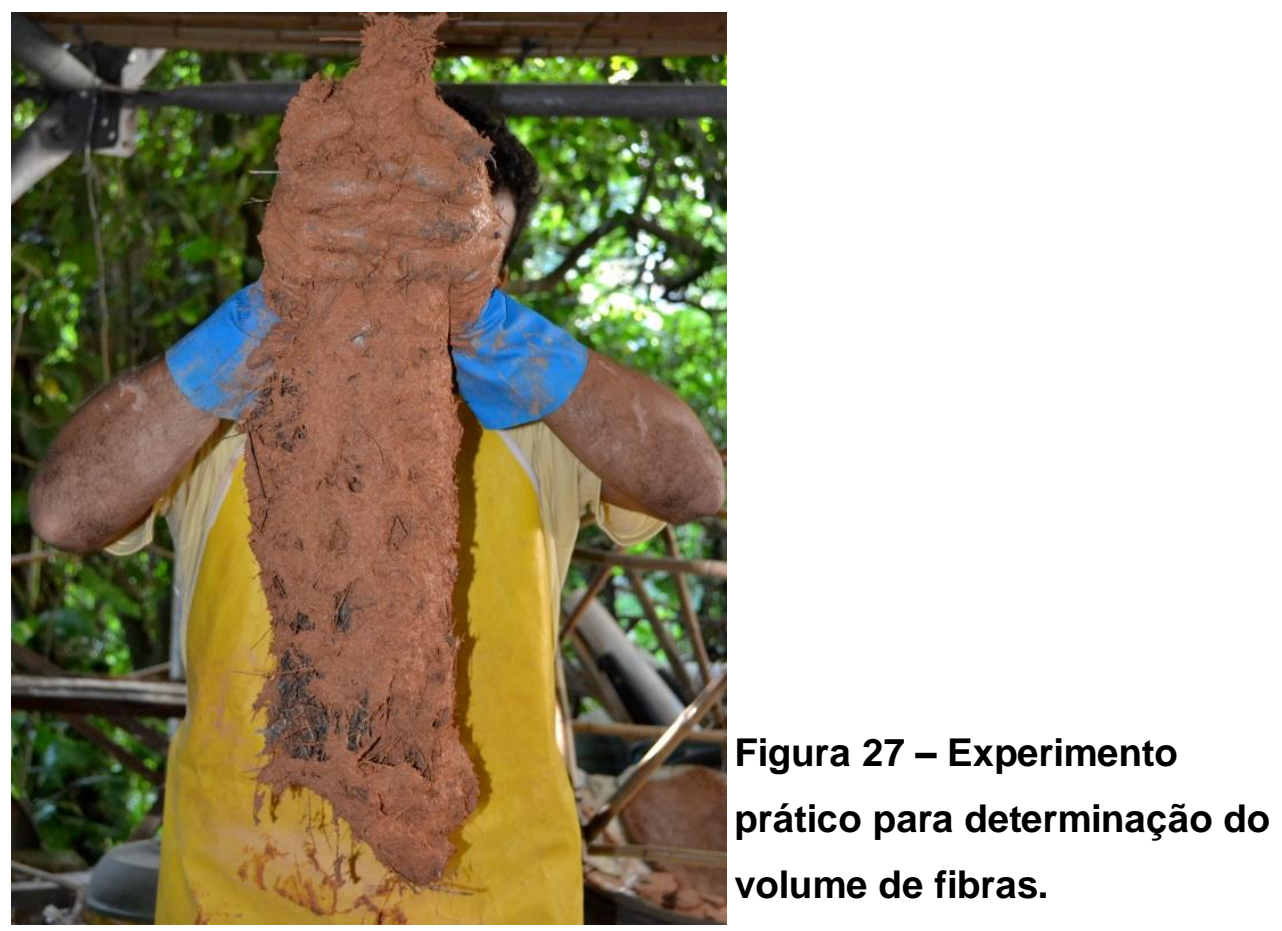

O experimento desenvolvido para saber se a proporção entre fibra e barro era suficiente foi o de misturarmos fibras e barro ao ponto que a mistura pudesse formar um cilindro capaz de ser erguido mantendo a forma por mais de 15 segundos suspenso no ar (Figura 27). Usualmente, a partir de $30 \%$ a $40 \%$ de fibras no volume do compósito produzia o efeito mostrado na figura. Esse experimento foi inspirado Belanko (in Marangoni, 2000) que diz que a quantidade mínima de fibras é quando encontramos resistência ao separar um compósito de barro-fibras em duas partes.

É importante ressaltar que este tipo de experimentação ocorreu por escassez de fibras nos laboratórios de campo, principalmente na Horta do Anil (RJ). Usualmente o LILD é conhecido pelo grande número de fibras buscando a saturação destas dentro do barro.

Sobre o uso da grama como reforço do compósito, apesar da baixa resistência mecânica do material, foi ponderado que não era em todas as situações a necessidade do uso fibras de alto desempenho. Em alguns casos, os compósitos funcionavam como camadas de capeamento dos elementos estruturais e criavam divisórias. Em outros casos, as construções eram estruturas de baixo carregamento então não precisaria ser submetido às mesmas tensões que uma estrutura de alto carregamento. Foi refletido que nessas situações era perfeitamente viável trabalhar com fibras menos nobres e de resistência à tração inferior. 
A pesquisa de campo gerou oportunidade de experimentos com fibras ainda menos usuais e até então impensadas. Em determinado momento da pesquisa houve uma escassez de fibras de grama na Horta do Anil. Foi preciso fazer experimentos com as plantas abundantes na região.

Testamos, por exemplo, tiras de jornais. Com o jornal e os recursos de manufatura disponíveis, produzimos compósitos visualmente grosseiros e, analisando superficialmente, fracos mecanicamente.

Ao trabalhar com as tiras de papel, com as folhas de uricana e de bambu foi perceptível a importância do processamento das fibras para diminuir a largura destas. Caso isto não seja feito uma área muito grande de fibras não fica envolvida pelo barro (Figura 28).

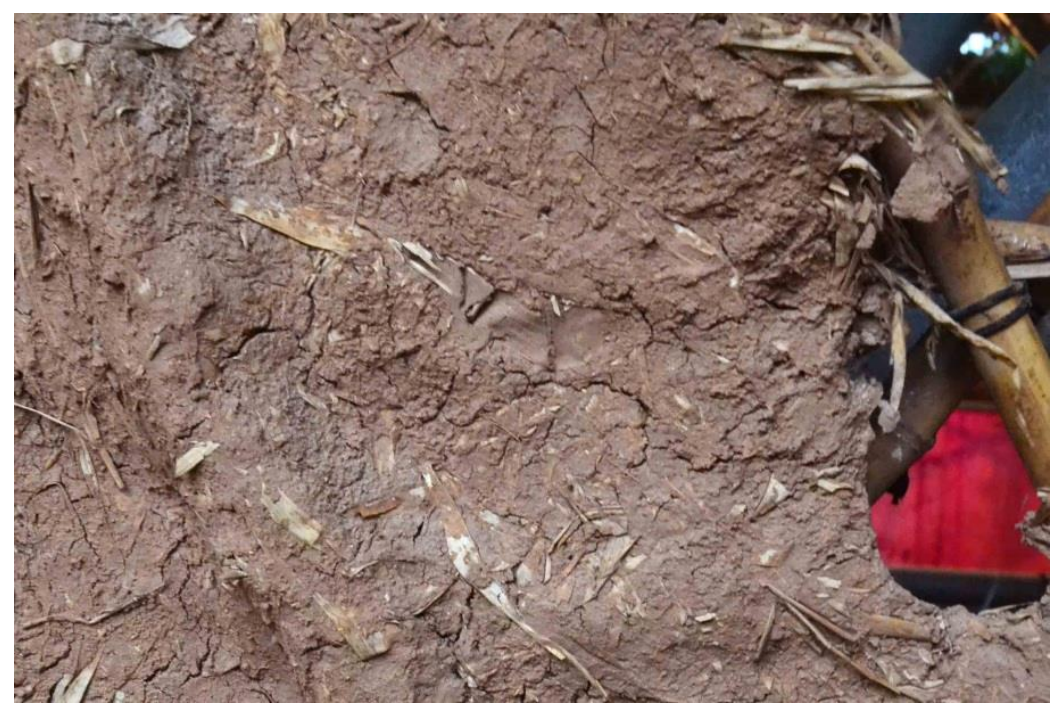

Figura 28 - Compósito de fibras de bambu e barro.

Isto é essencial se for considerado a busca por camadas finas de fibrobarro. $O$ experimento apontou a necessidade de processar as fibras para aumentar a superfície de interação entre os componentes do compósito.

A partir de conversas com integrantes da equipe da Horta do Jardim Anil (RJ), foi possível conhecer à Colônia (Alpinia speciosa, Figura 29 e Figura 30), planta abundante na região e conhecida por suas propriedades medicinais (IFCE-Instituto Federal do Ceará s.d.). Foram realizados alguns testes para a obtenção de fibras desta planta. 


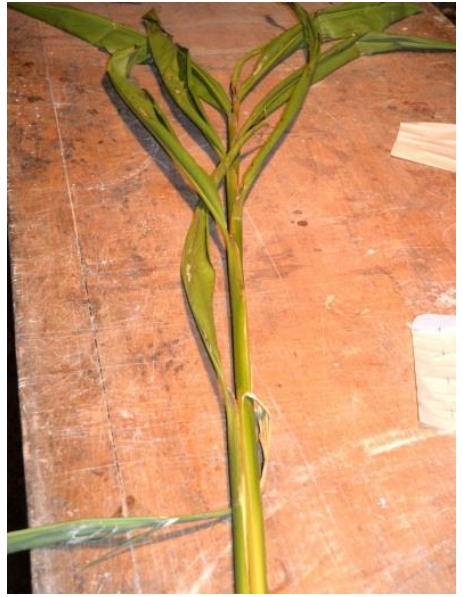

Figura 29 - Planta Colônia (Alpinia speciosa)

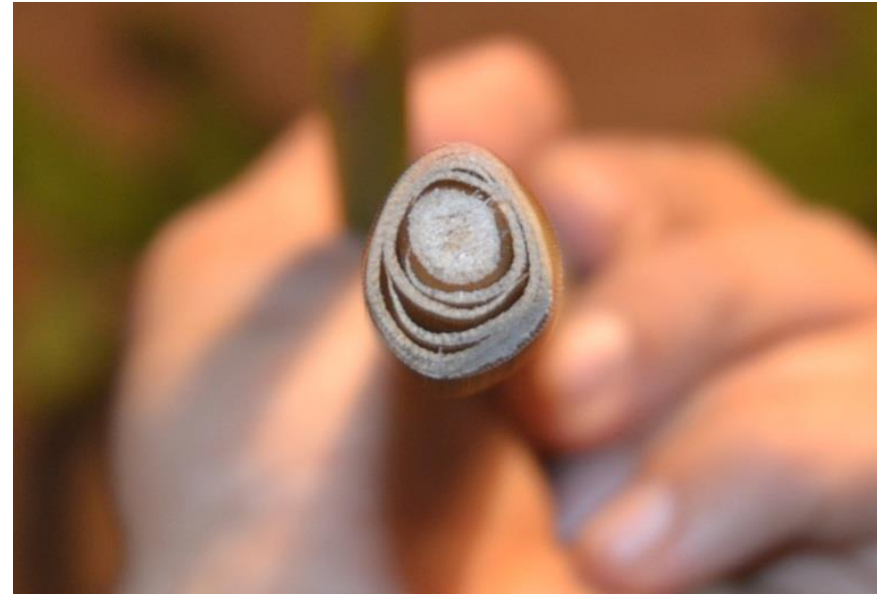

Figura 30 - Detalhe da planta Colônia

Foi experimentado processar a planta seca e cortada em pedaços. Mas a técnica mais eficiente encontrada foi o contínuo martelar da planta recém-colhida (Figura 32 e Figura ). Com esta técnica, foram obtidas fibras da planta em pequenos fios de $1 \mathrm{~mm}$, que depois de cortados, tornaram-se ideal para o uso (Figura 33).

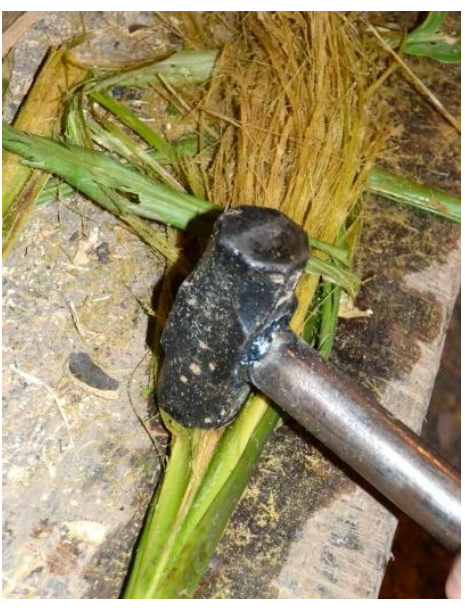

Figura 31 -

Processamento da fibra utilizando um martelo.

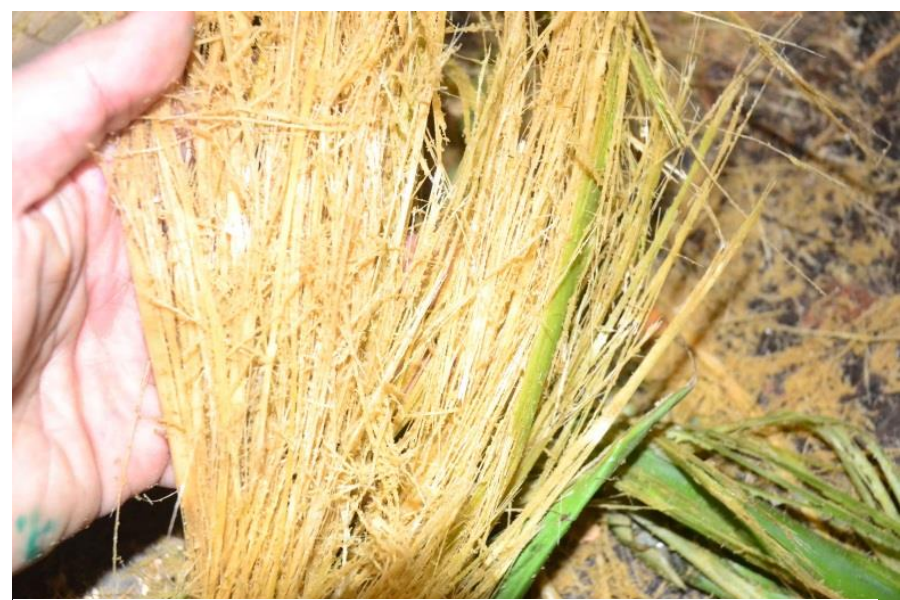

Figura 32 - Fibras resultantes da ação de martelar 


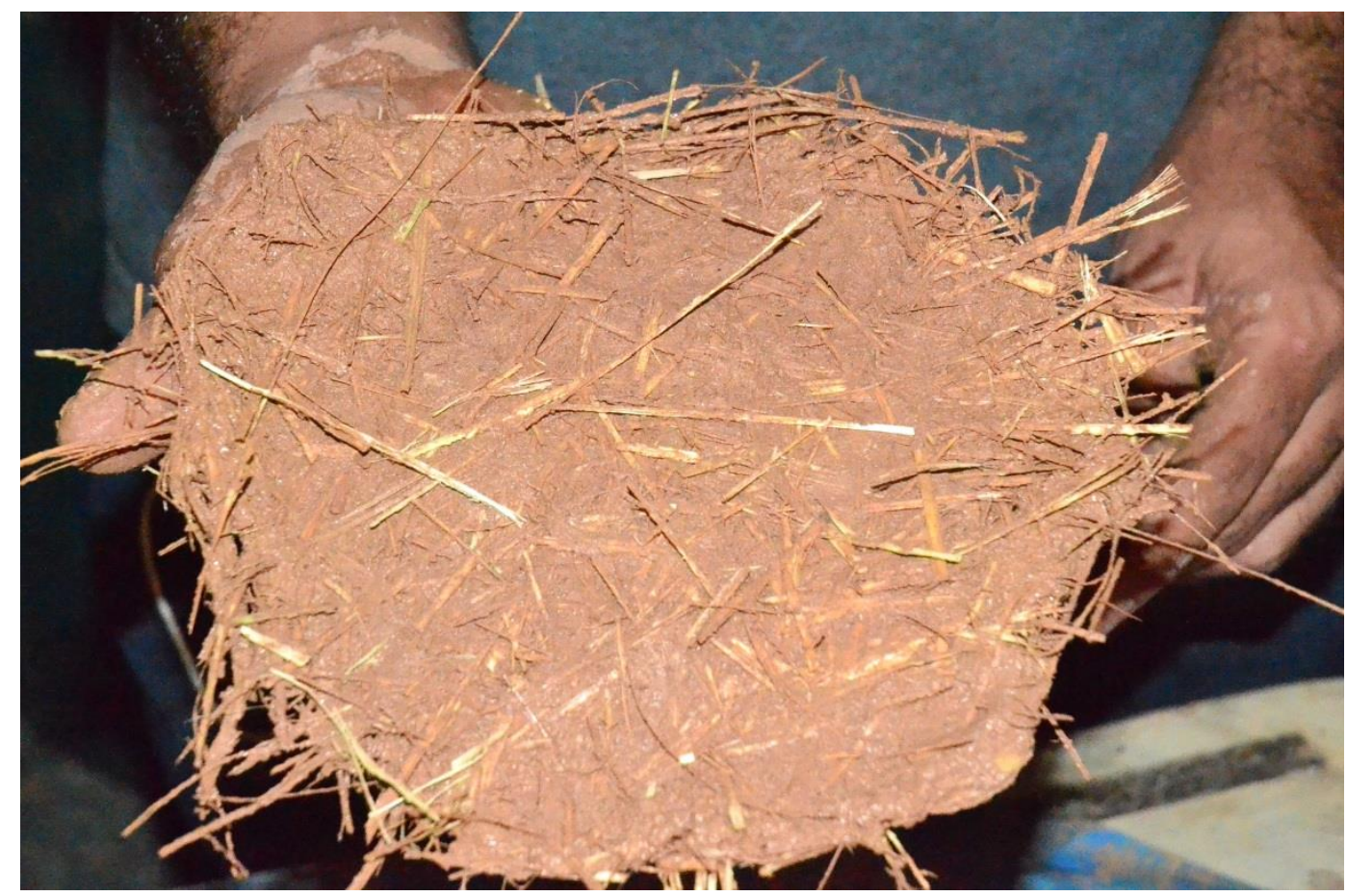

Figura 33 - Compósito de colônia-barro

Foram feitas algumas chapas experimentais de colônia-barro e jornal-barro que mantiveram a forma parecendo uma nova possibilidade de fibras a serem usadas na Horta do Jardim Anil (RJ). Contudo a aplicabilidade destas fibras não pôde ser averiguada na pesquisa de campo pois, em uma determinada visita ao Anil, foram doados uma grande quantidade de piaçava (Attalea funifera) remanescente de uma construção feita próxima à Horta. Nas fibras de piaçava, a quantidade de água utilizada era cerca de 1/3 superior aos demais compósitos, apresentando pouca aderência do barro depois de seca (Figura 34 e Figura 35). Mostrou resultados satisfatórios para camadas de compósitos não-estruturais. Ou seja, estruturas que estas fibras não sejam um dos principais elementos estruturantes.

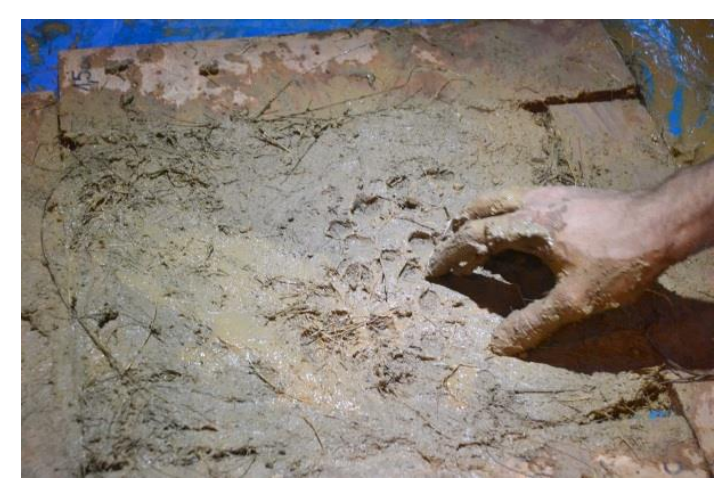

Figura 34 - Compósito sapê-barro sendo feito

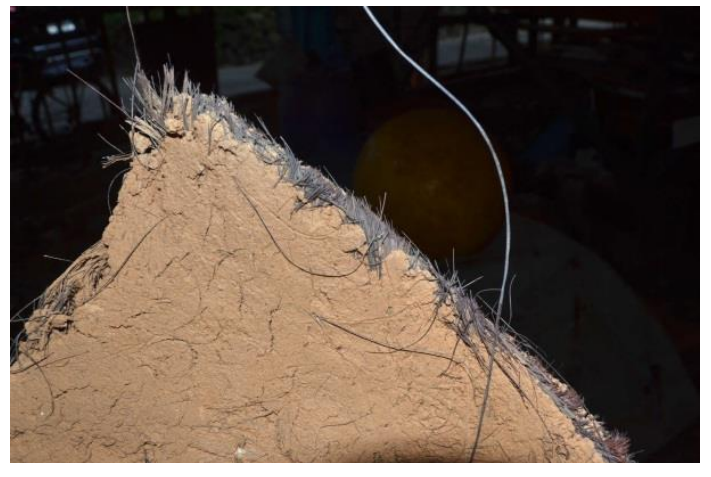

Figura 35 - Depois de cortar o compósito, foi perceptível o que barro com a vibração 


\subsection{Películas de capeamento}

Neste subcapítulo serão descritos os testes de materiais e método de aplicação de películas de capeamento. Estas películas têm, como uma de suas funções, de preservar a estrutura construção da ação de processos erosivos. No caso dos ambientes de clima tropical e subtropical o principal foco de atenção deve ser a ação das intempéries.

Serão descritos as técnicas de preparo e aplicação e será descrito os cuidados recomendados. Esta secção está dividida em duas partes: películas finas e películas grossas. A intenção é demonstrar as particularidades de cada etapa e as análises feitas no processo de experimentação.

Como foi dito anteriormente, foram feitos experimentos com os materiais sugeridos pelos autores pesquisados de acordo com a disponibilidade nos contextos pesquisados. Não será feita uma descrição minuciosa do que ocorreu mas, será ressaltado os aspectos gerais e as particularidades observadas.

\subsubsection{Camadas grossas}

Optamos por descrever as películas grossas antes das películas finas porque as duas podem fazer parte da mesma construção. Como foi dito anteriormente, Snell \& Callahan (2009) e Guelberth \& Chiras(2009) descrevem a importância de se produzir mais de uma camada para produzir um bom acabamento e preservar a construção. Autores como Minke (2009) mencionam que a camada de cobertura com cal hidratada deve apresentar espessura aproximada de $5 \mathrm{~mm}$ para que tenha uma boa eficiência.

Foi percebido que as camadas com mais de $0,5 \mathrm{~cm}$ de espessura, grossas, aplicadas sobre as esferas não funcionavam satisfatoriamente. Ao aplicar uma mesma camada sobre as esferas e sobre placas côncavas foi observado que por mais cuidados que houvesse, o primeiro sempre apresentava fissuras maiores que os testes feitos sobre as placas côncavas (Figura e Figura 37 ). A partir dos relatos de Fathy (1982), foi suposto que, provavelmente, seria necessário com a adição de mais areia (o que aumentaria o peso) ou fibras (o que aumentaria a espessura) para diminuir a contração do compósito. 


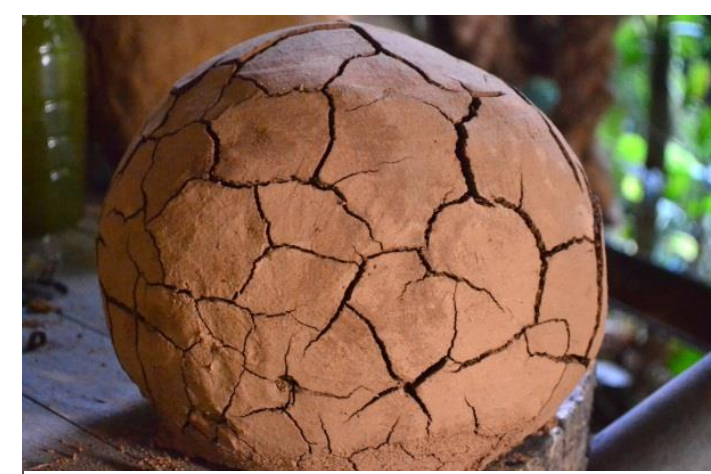

Figura 37 - Camada de capeamento grossa rachada.

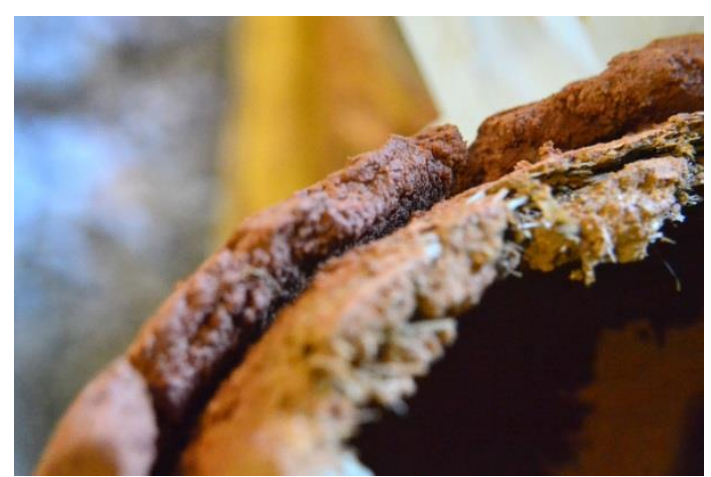

Figura 36 - Detalhe da laminação entre a camada de acoplamento e uma esfera de fibrobarro.

Entre os cuidados experimentados estavam, por exemplo, o de cobrir a camada com papel filme para aumentar o tempo de secagem. Esta técnica, amplamente utilizada pelo LILD, que nos experimentos com argila solucionou a questão das rachaduras sem a necessidade de qualquer outro tipo de cuidado, não foi plenamente eficiente, nesse caso, foi analisado que as esferas eram pequenas demais para a espessura de camada aplicada. Além da diferença de peso entre a esfera e a camada de capeamento, a área da superfície da esfera não foi o suficientemente grande para a contração da camada de capeamento. As esferas também podem ter absorvido parte da humidade da camada de capeamento que secou mais rapidamente do que deveria.

As únicas camadas grossas que não sofreram tanto com as fissuras foram as camadas que continham muitas fibras como as camadas de cal hidratada (Figura 38- camada de cal hidratada sem fibras. Superfície apresenta diversas fissuras.Figura 38 e Figura 39). Independente se a superfície era côncava ou convexa, com a experimentação das camadas grossas foi possível perceber algumas particularidades deste processo que precisam ser respeitadas em todo o processo de construção. Comparando com as camadas de barro, as camadas de cal retraíram menos que as camadas de barro. 


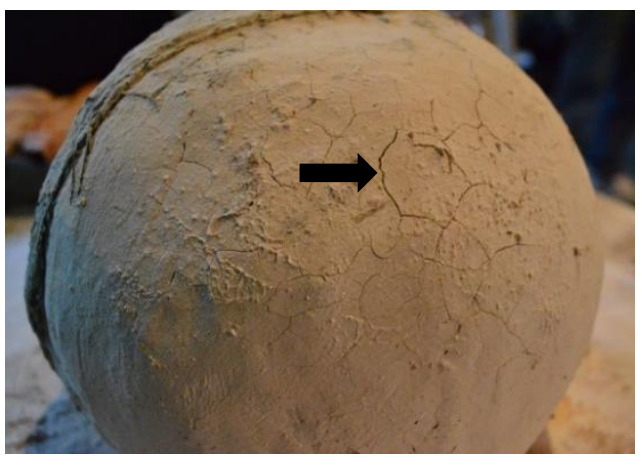

Figura 38- camada de cal hidratada sem fibras. Superfície apresenta diversas fissuras.

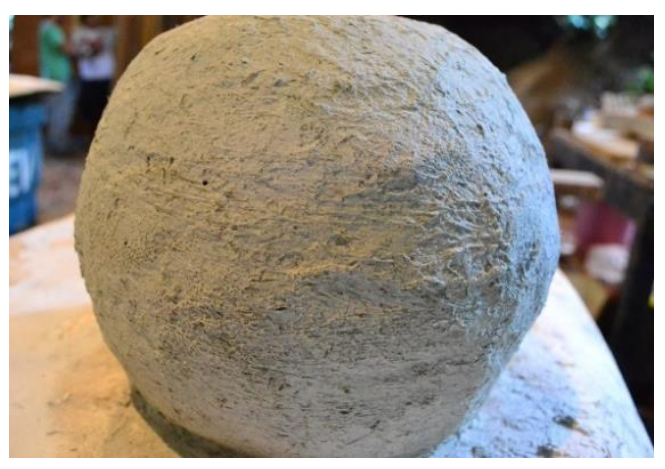

Figura 39 - Cobertura de cal hidratada com fibras de grama. Sem fissuras aparentes.

Os experimentos mostraram que antes de aplicar a camada de cobertura era importante aumentar a área de contato entre as camadas para dificultar a delaminação (Figura 40).

É importante estar atento para que a secagem da camada de cobertura aconteça da maneira mais lenta possível. Isto ocorre devido ao fato de materiais como a argila, e até mesmo a cal, retraírem no processo de secagem. Para amenizar e até mesmo acabar com as fissuras foram utilizadas as referências de Snell \& Callahan (2009) e Guelberth \& Chiras (2009) que falam no uso de uma esponja úmida (Figura 41) ou um aspersor para hidratar homogeneamente toda a superfície. O gestual de hidratação após a aplicação da camada era um pouco diferente do feito antes da aplicação, após a aplicação da camada a hidratação foi feita usando movimentos circulares com uma esponja úmida.

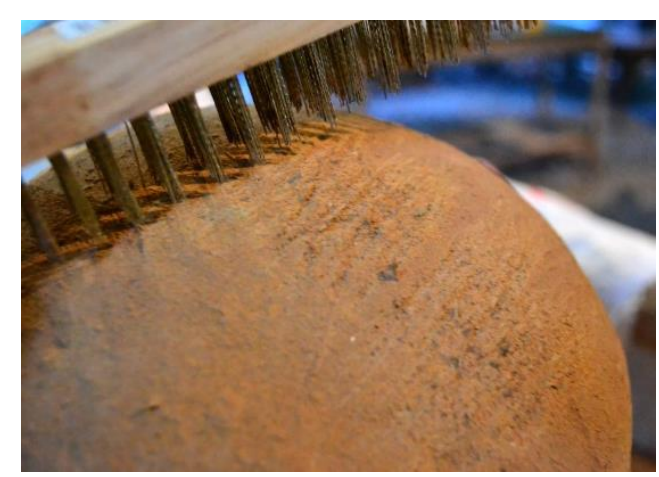

Figura 40 - Ranhuras feitas na superfície para aumentarmos a área de contato.

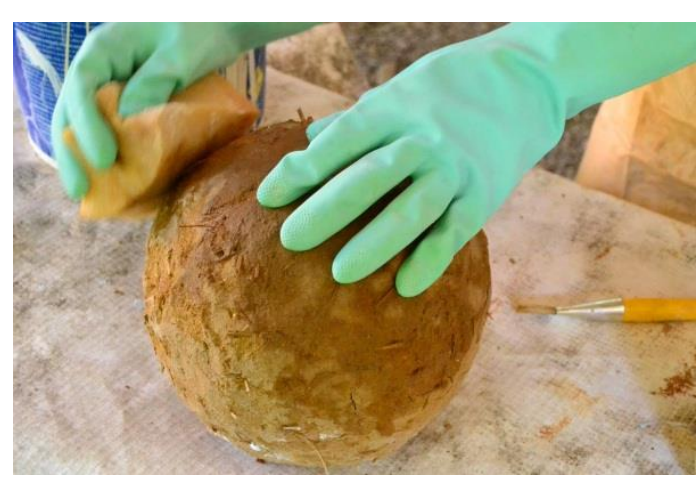

Figura 41 - Hidratação da superfície antes da aplicação da camada. $O$ mesmo procedimento foi feito após a aplicação da 
A técnica de utilizar movimentos circulares realmente diminuiu a maioria das fissuras. Especialmente aquelas menores de $2 \mathrm{~mm}$ e feitas enquanto este materiais não estavam completamente secos. Nas situações onde as fissuras eram muito grandes ou o tempo de secagem já estava quase completo, a solução encontrada foi fazer uma nova aplicação da camada de superfície. Esta solução se faz ainda mais útil com a pasta de cal hidratada que, após seca, não volta a um estágio moldável.

O cuidado de hidratar a camada de base antes de aplicar a camada de cobertura também facilita a integração entre as duas camadas. Neste processo, ao hidratar a base, ela irá inchar e ao aplicar a $2^{\underline{a}}$ camada, ambas estarão inchadas e, portanto irão se retrair simultaneamente durante a secagem, diminuindo as tensões de cisalhamento na superfície adesiva e diminuindo a delaminação. Por outro lado, a camada base, estando hidratada, não puxará a água da camada de cobertura, e a retração da cobertura será mais lenta, diminuindo os defeitos de retração. A incidência de fissuras diminuiu tanto em quantidade quanto em profundidade.

Guelberth \& Chiras (2009) falam do uso de fibras curtas nas camadas secundárias, mas que não devem estar presente na última camada. Estes autores falam apenas, mesmo que remotamente, sobre fibras naturais de alto desempenho.

Como explicado anteriormente, trabalhando de acordo com as realidades locais como as do Anil (Jacarepaguá - RJ) e em Cachoeiras de Macacu (RJ), foram experimentadas fibras disponíveis nesses contextos. Ambos os locais, não dispunham de fibras de sisal, trigo ou arroz. Por isso fizemos experimentações com bambu, embira de banana e até mesmo grama e papel. As de grama, por exemplo, quase eliminaram as fissuras sem afetar a superfície inicial.

Ao associar muitas fibras com pasta de cal hidratada (cerca de 1:1 em volume), por exemplo, fizemos um compósito extremamente maleável que só foi possível aplicar de modo eficiente com o uso das mãos (Figura e Figura 43). A camada ficou extremamente grossa necessitando receber uma camada fina para completar o acabamento. 


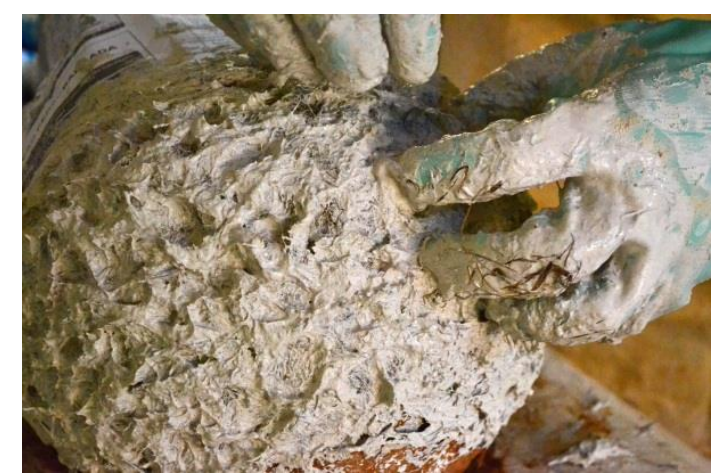

Figura 43 - Feltragem do

compósito cal-fibras de grama.

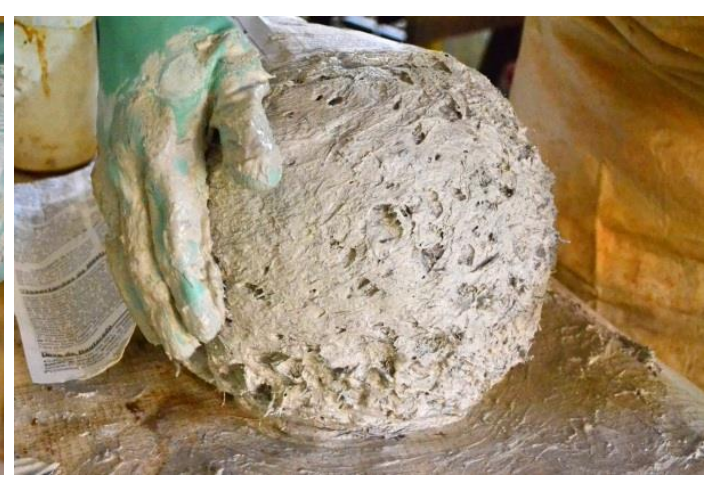

Figura 42 - Alisando o compósito para dar um acabamento mais homogêneo.

Quando foram feitos testes com uma menor quantidade de fibras, foi perceptível que a melhor ferramenta para aplicar a camada era uma espátula bem flexível. As espátulas de metal disponíveis no mercado não apresentavam tanta flexibilidade dos cartões plásticos, como os utilizados como bilhetes de metrô. Usando esta ferramenta e aplicando-a em mais de um sentido, a incidência de fissuras diminuiu sensivelmente sendo facilmente resolvidas com o uso da esponja umedecida e movimentos circulares enquanto a cobertura ainda estava úmida (Figura 44).

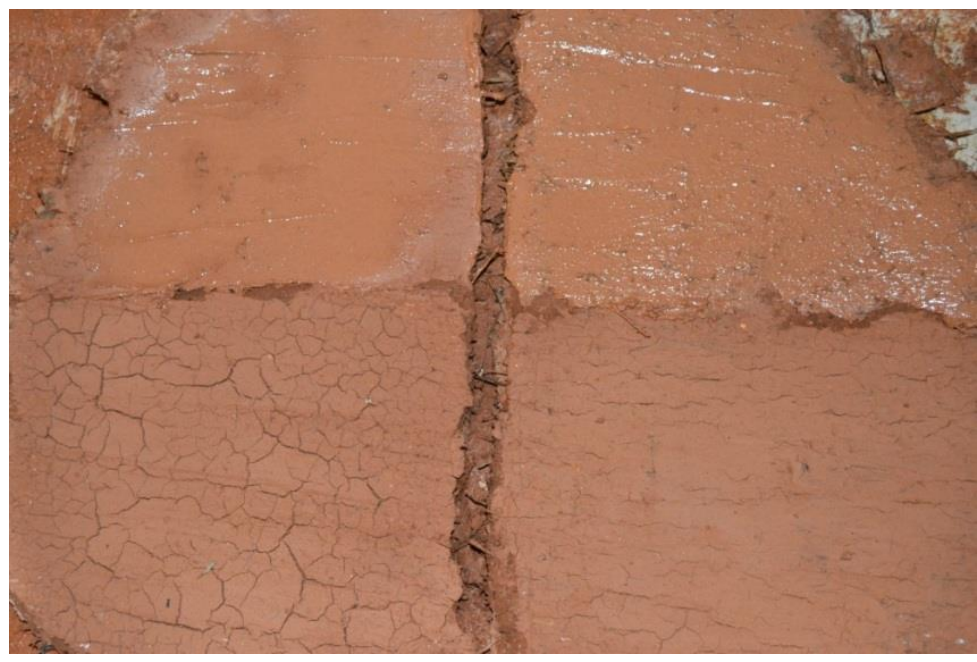

Figura 44 - 4 testes de capeamento com solo e cal. Os quadrantes superiores foram hidratados e os quadrantes da direita foram misturados com fibras.

As espécies experimentadas como a Grama Esmeralda (Zoysia japônica) e a Batatais (Paspalum notatum) demonstraram-se uma possibilidade simples e barata de se aproveitar os recursos disponíveis. Foi perceptível que quanto 
maior for a proporção de fibras na composição desta camada, menor a incidência de fissuras, mas menor será a adesão da cal hidratada na parede de barro. Ao mesmo tempo, grandes proporções de fibras aumentam muito o aspecto rústico da camada e sua capacidade higroscópica (capacidade de absorver a água) estimulando aplicar uma nova camada de capeamento para regularização.

No processo de produção de camadas grossas foram feitos experimentos com mucilagem de cactos palma. Os autores que pesquisados (Guelberth \& Chiras, 2009 e Lengen, 2004) indicaram procedimentos para a produção desta substância. Ao invés de hidratar com água, a mucilagem de cactos foi usada como substituta. $\mathrm{Na}$ produção de camadas grossas a solução apresentou diferenças significativas. O composto sobre esferas continuou rachando, mas seus efeitos foram mais perceptíveis como camada fina.

\subsubsection{Películas de capeamento}

$\mathrm{Na}$ investigação de técnicas de aplicação que não promovessem fissuras trabalhamos com camadas muito finas. Em alguns casos, as películas eram tão finas que se assemelhavam a pinturas.

Uma grande questão surgir ao produzir as películas finas era saber se esta era espessa o suficiente para proteger os corpos de prova da ação da água. Como os corpos de prova tinham uma superfície irregular, outra função desta camada acabou sendo a correção de imperfeições, tornando a superfície visualmente mais homogênea.

A aplicação de películas possibilitaram experimentos com cola PVA (Xavier, 2009), mucilagem de cactos (Lengen, 2004) e resina de mamona. A resina de mamona foi experimentada em uma esfera de fibrobarro e logo seu efeito foi notado. A esfera pintada ganhou brilho e resistência ao ponto de ficar bem mais difícil fazermos marcas na superfície. Ao colocar a mão dentro das esferas ocas, era perceptível a diferença de temperatura entre as duas esferas. Não foi difícil concluir que a resina vedava grande parte da porosidade da parede externa de terra crua e nossos testes colaboraram com esta teoria (Figura 45). 


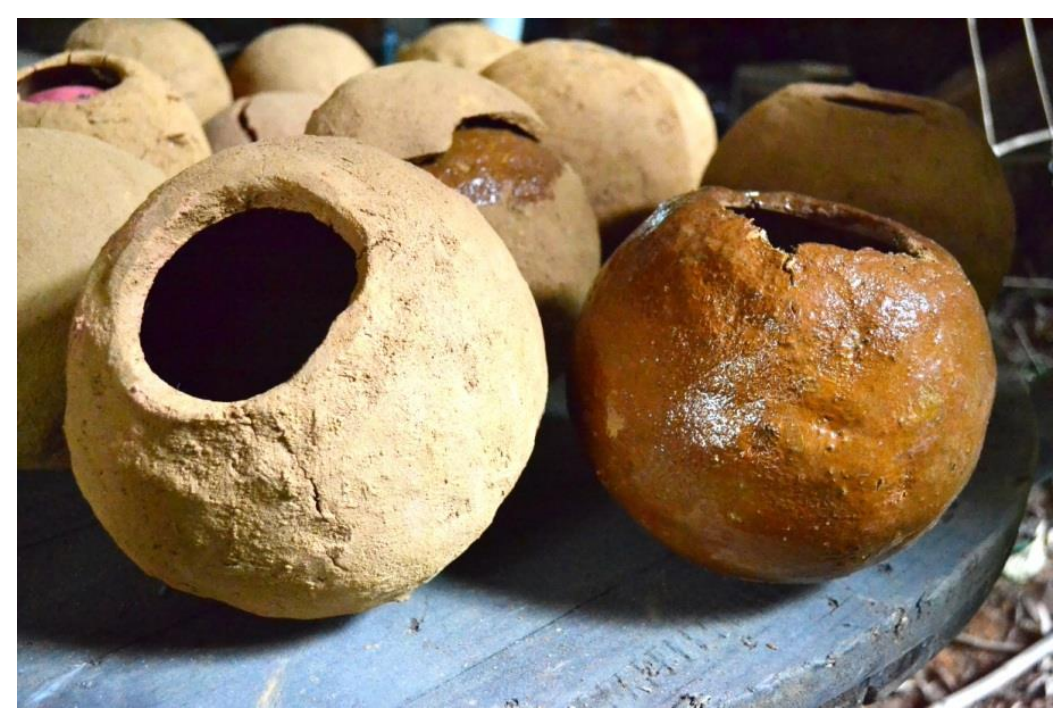

Figura 45 - Duas esferas ocas. A da direita recebeu uma camada de resina de mamona.

O brilho e até mesmo a impermeabilidade da superfície, podem ser diminuídos se a resina estiver misturada com o solo. Contudo, devido ao alto custo de produção, o uso da resina deveria ser feito em casos específicos.

A aplicação da mucilagem de cactos e da cola PVA (poli-vinil acetato), polímero sintético amplamente usado em móveis de madeira, apresentou resultados animadores. Ao aplicar este adesivo (Figura 47), foi observado que a parede das esferas absorvem o líquido, mesmo que lentamente, cada camada aplicada. Com aplicação de diferentes camadas, era perceptível a saturação da superfície de argila que não mais absorvia a cola (Figura 46).

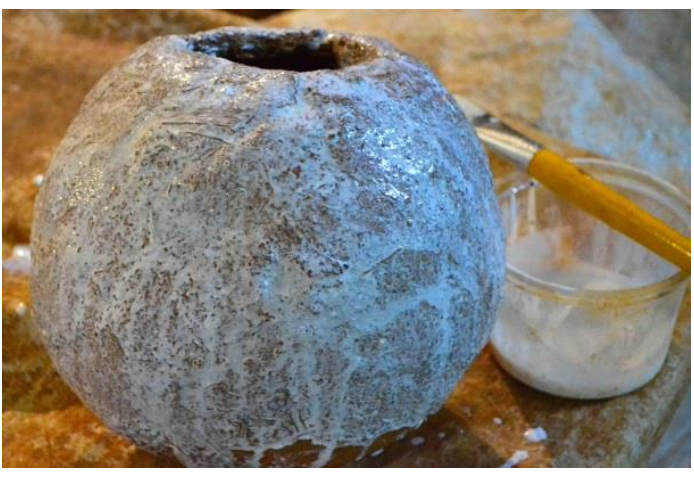

Figura 46 - Aplicação de PVA usando pincel.

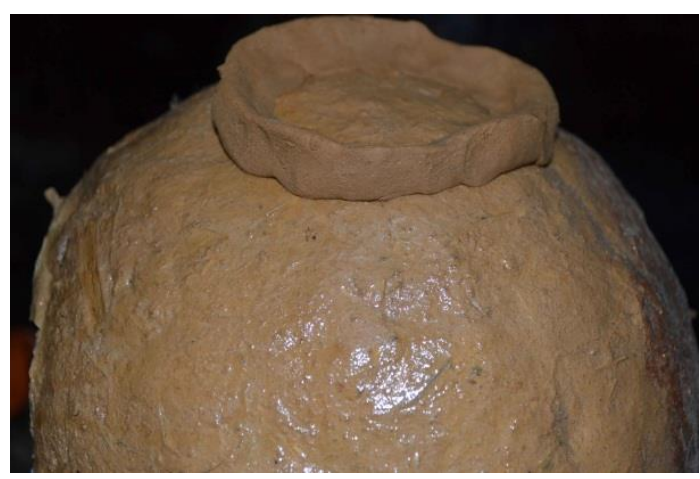

Figura 47 - Cola PVA depois de seca

A aplicação dessa camada com pulverizador demonstrou ser agressiva à superfície, facilitando a erosão. A técnica mais eficaz foi aplicar com pincel. Assim a coloração e textura das esferas ocas mudavam a cada camada aplicada, com uma menor absorção. Provavelmente se esta técnica precisar ser empregada em grandes superfícies o uso do pulverizador será mais eficiente, 
mas mesmo nessas situações, uma ou duas camadas iniciais utilizando um pincel ou rolo de tinta seja mais apropriado, para evitar erosão de base.

Também foi experimentada a mucilagem feita a partir de polvilho de mandioca (Manihot esculenta) descrita por Jorge Belanko (in Marangoni, 2000). Contudo, os experimentos feitos tanto no estado puro quanto misturado com terra mostraram que, apesar da impermeabilidade inicial (Figura 49 ), em poucos dias a superfície delaminava da camada aplicada (Figura ). Também foi experimentada esta goma misturada com terra. Apesar uma textura agradável esteticamente (Figura 49 , esfera da esquerda) os resultados foram parecidos ao da esfera da figura 49.

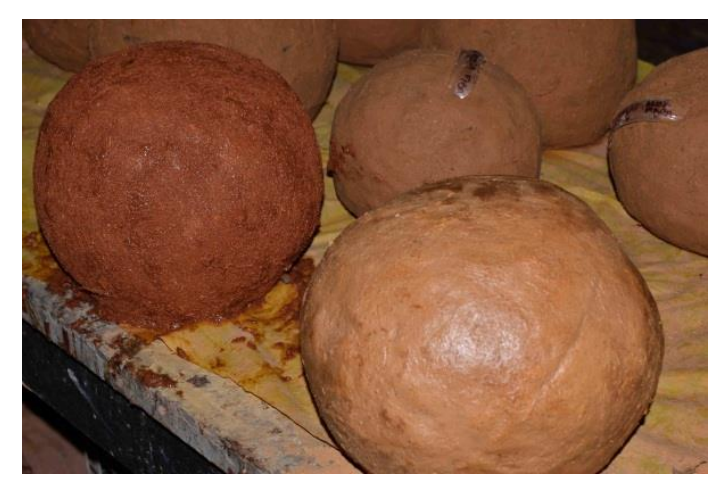

Figura 49 - Esferas cobertas com polvilho azedo. A da esquerda foi misturada com terra. Na da direita foi aplicado uma película fina.

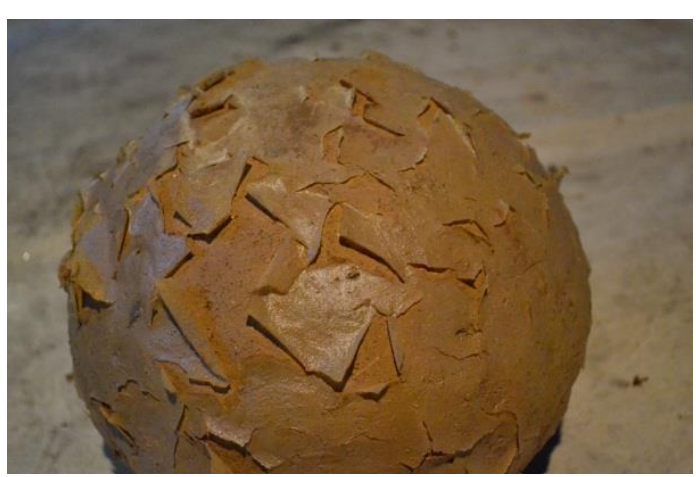

Figura 48 - Camada fina de polvilho azedo depois de algumas semanas.

\subsection{Testes de misturas}

Neste item serão relatados os experimentos feitos misturando mais de um dos materiais mostrados anteriormente. Serão mostrados os experimentos bem sucedidos e também aqueles que tiveram um bom rendimento, mesmo que, por um curto espaço de tempo.

A intenção dos experimentos era procurar singularidades que pudesse ajudar a entender um pouco mais do seu funcionamento, ampliando o repertório técnico para que fosse possível fazer mudanças de acordo com o contexto socioambiental onde a pesquisa foi aplicada.

A metodologia foi a mesma dos itens anteriores: a análise qualitativa dos experimentos feitos dentro do LILD tendo como referência Belanko (in Marangoni, 2000), Lengen (2004), Xavier (2009), Alvares (2008) e Leme (2003 e 2008). Também forma observados os gestos e outras ações possíveis para o desenvolvimento do objeto construtivo. Parte deste repertório foi utilizada na 
aplicação da técnica nos contextos sociais dos laboratórios de campo. Os saberes aprendidos nestes itens foram princípios para as interações entre os envolvidos dessa próxima etapa.

Como a cal hidratada foi citada por muitos como o material com melhor relação custo-benefício, a maioria dos testes foram feitos com esse material. Um dos primeiros experimentos foi misturar cal hidratada, terra e fibras. A cal hidratada necessita ter superfície adequada para realizar a ancoragem. Isto foi obtido através do aproveitamento das fibras que "sobram" da superfície receptora ou por ranhuras na mesma (Figura 40, página 65).

Sobre uma superfície curva, foram feitas quatro tipos de aplicação. $\mathrm{Na}$ Figura 50 é possível perceber que: No quadrante "A" foi aplicado cal com fibras; no quadrante "B" foi aplicado fibras com goma de polvilho; no quadrante "C" aplicamos cal com goma de mandioca e no quadrante "D" aplicamos terra com goma (2:1 de proporção).

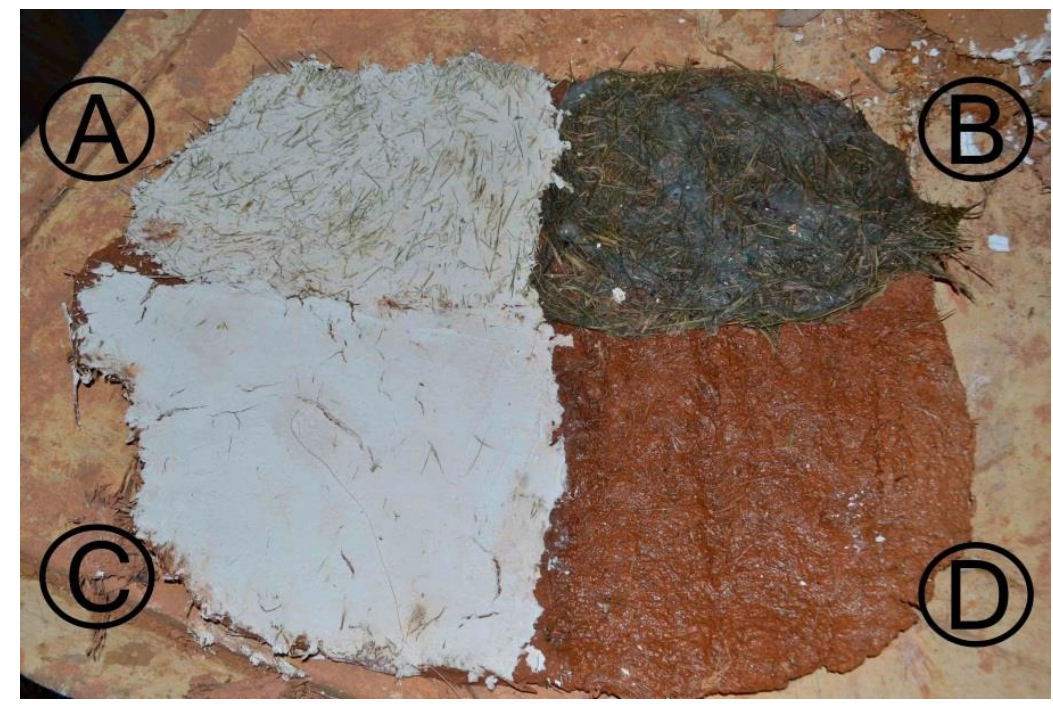

Figura 50 - Quatro combinações de aplicação de camada de cobertura usando pastacal, fibras e goma de mandioca

Na camada "A" a cal foi misturada com goma de mandioca para depois acrescentar as fibras. Contudo, a mistura não foi homogênea. A tendência da goma é ficar aglutinada e com isso alguns grumos não isolavam as fibras da cal. Algumas semanas depois o composto pareceu inalterado.

O quadrante "B" refletiu essa aglutinação da goma. Em alguns pontos na foto é possível notar algumas manchas brancas sinalizando o polvilho que não se misturou homogeneamente. Algumas semanas depois o brilho do compósito desapareceu e as fibras ficaram expostas. 
Já o quadrante "C" foi o que apresentou melhores resultados. Contudo a aplicação não foi fácil e ao invés das microrachaduras homogeneamente espalhadas, notamos rachaduras de 1 a $3 \mathrm{~cm}$ e de em alguns pontos. A tendência do material é de retrair ao perder água e onde havia menor quantidade de polvilho misturado à cal ocorreram as falhas. Tanto o quadrante "A" quanto o "C" apresentaram um aspecto granulométrico depois do compósito seco, que só foi útil para aplicar uma segunda camada.

No quadrante "D" fizemos os mesmos experimentos das Figura 49 e Figura , só que desta vez com mais terra e o resultado foi semelhante. A camada se descola da placa curva.

O mesmo procedimento foi feito em um experimento de mistura da pastacal a outros elementos usados pelo LILD e pelos autores sobre construção com terra crua. Como é possível observar na Figura 51, foram feitos experimentos de pasta de cal hidratada em seu estado puro ("A") sendo hidratada periodicamente utilizando uma esponja. Um processo parecido foi feito no quadrante " $C$ " só que não usamos a esponja para auxiliar no fechamento de fissuras. No quadrante "B" foi misturado mucilagem de cactos e uma esponja foi utilizada para tentar diminuir as fissuras. O mais surpreendente na nossa opinião foi a mistura de cal com a cola PVA (quadrante "D").

No quadrante " $D$ " mesmo com a técnica de hidratar e passar a esponja, a secagem foi bem mais rápida e por isso o efeito do uso da esponja foi inútil.

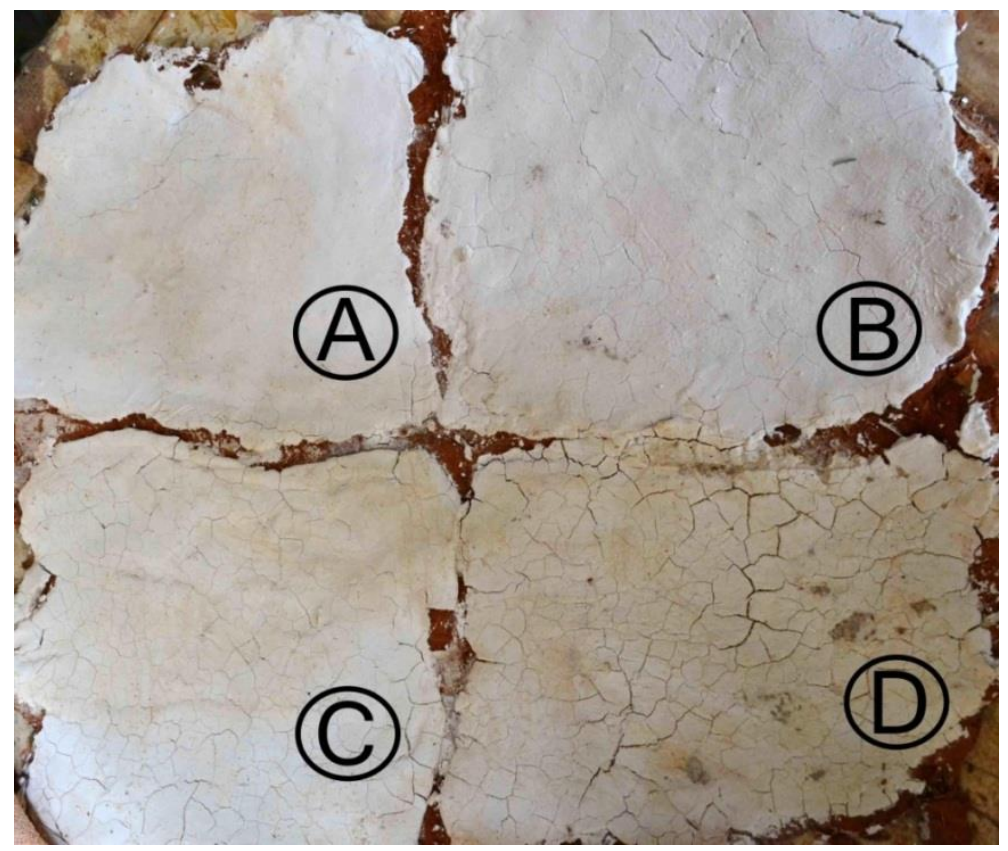

Figura 51 - Cal hidratada misturada com outros protetores usados em construções de terra crua. 
Por sugestão dos relatos de Belanko (in Marangoni, 2000) e Snell \& Callahan (2009), foram feitos experimentos com o uso de caseína misturada com cal. Foram acrescentadas colheres de leite em pó a um pote com cal hidratada. Aos poucos fomos ocorreu uma mudança na textura da cal hidratada que passou a ter um aspecto cremoso e superfície brilhante. A mistura exigiu mais força para efetuar a homogeneização com movimentos circulares. O composto foi ganhando um aspecto de borracha e um brilho lembrando um queijo minas curado. Inicialmente pareceu ser um experimento promissor. Contudo depois de alguns dias notamos que o composto tornara-se quebradiço. O resultado repetiuse mesmo com a diminuição da quantidade de caseína utilizada (Figura 53 e Figura 53 - ).

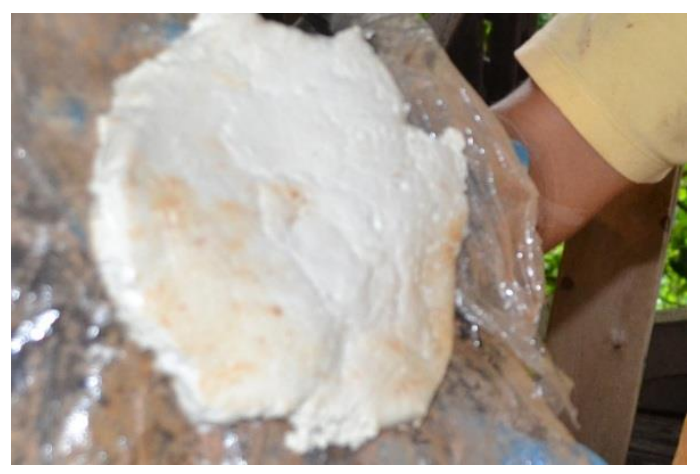

Figura 53 - Cal-caseína sendo produzida

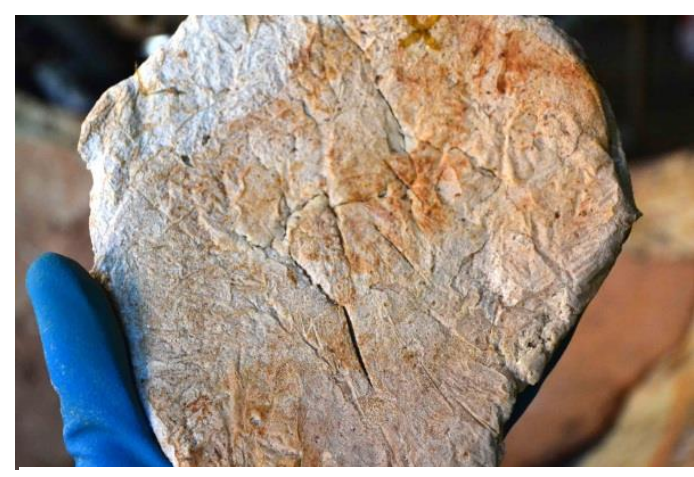

Figura 52 - Depois de duas semanas o composto ficou quebradiço

Depois de alguns meses, alguns dos experimentos, ao invés da coloração branca homogênea, adquiriam manchas pretas por todo o composto, parecendo que a quantidade de caseína fora excessiva. Foi observado que, no caso do uso da pasta de cal hidratada, o que conta mais é o gestual de hidratação antes e depois da aplicação.

\subsection{Experimentos de cal hidratada de diferentes tipos}

Ao longo do processo de pesquisa com a cal hidratada fizemos alguns experimentos com diferentes tipos de cal que foram encontradas. Não foi possível adquirir a cal em seu estado mais puro (cal virgem). As empresas encontradas que comercializam este tipo de material não trabalhavam com o comércio de varejo do Rio de Janeiro.

Como esses sacos tiveram diferentes origens, data de fabricação e procedências diferentes, as substâncias foram nomeadas a partir de onde as 
encontramos. É possível afirmar que o aspecto visual da cal já deu vários indicativos de como seria a sua utilização desde a sua hidratação até o uso propriamente dito.

Os 5 tipos de cal encontrados receberam as seguintes denominações:

\begin{tabular}{|c|c|c|c|}
\hline $\begin{array}{l}\text { Marca da Cal ou } \\
\text { Local onde foi encontrada }\end{array}$ & Tipo de Cal & Aspecto geral & Nome dado \\
\hline $\begin{array}{c}\text { Cruzada Material de } \\
\text { Construção } \\
\text { (Loja Especializada) }\end{array}$ & $\mathrm{CH} 1$ & $\begin{array}{l}\text { Extremamente } \\
\text { branca }\end{array}$ & $A$ \\
\hline $\begin{array}{c}\text { Itaú - Grupo Votorantim } \\
\text { (Loja popular) }\end{array}$ & $\mathrm{CH} 3$ & Branca & B \\
\hline $\begin{array}{c}\text { LILD } \\
\text { (Estoque) }\end{array}$ & $\mathrm{CH} 3$ & $\begin{array}{l}\text { Tom de bege } \\
\text { muito claro } \\
\text { (Validade } \\
\text { vencida) }\end{array}$ & C \\
\hline $\begin{array}{l}\text { Bambutec } \\
\text { (Estoque) }\end{array}$ & $\mathrm{CH} 3$ & $\begin{array}{l}\text { Tom de bege } \\
\text { (Validade } \\
\text { Vencida) }\end{array}$ & $\mathrm{D}$ \\
\hline $\begin{array}{l}\text { Laboratório da Arquitetura } \\
\text { Estoque }\end{array}$ & $\mathrm{CH} 3$ & Cinza & $E$ \\
\hline
\end{tabular}

Tabela 1 - Modelos de Cal hidratada encontrados.

A aplicação dos diferentes tipos de cal foi feita em películas sobrepostas. A intenção era produzir a menor superfície para averiguar observações feitas durante a construção do túnel do LILD e revestimento da casa de pau-a-pique. Ambos os estudos de caso serão analisados no próximo capítulo.

Essa técnica foi utilizada para evitar a formação de grandes fissuras e ao mesmo tempo aproveitar as pequenas fissuras formadas para ajudar na ancoragem da camada seguinte. Para aplicação das camadas foi utilizada esponja, água, pequena espátula de plástico e pincel.

Durante a laminação de películas cal mais uma vez foi vista a importância da hidratação da superfície antes da aplicação da camada seguinte. Em alguns casos, especialmente quando a segunda película era aplicada deois de sete dias que a primeira camada, ocorria uma delaminação da película. (Figura 54). 


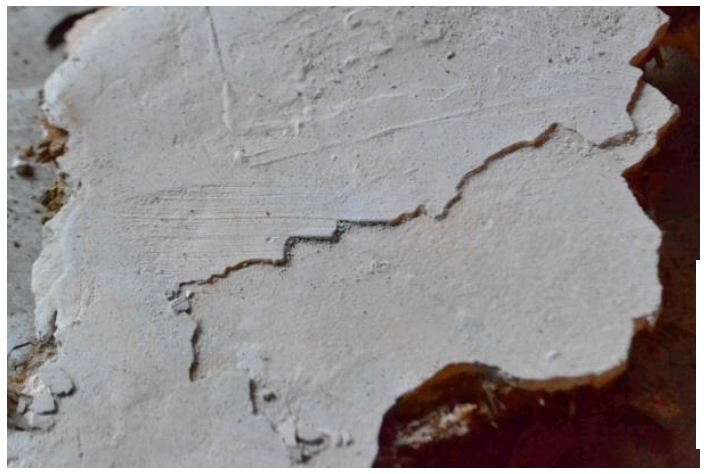

Figura 54 - Delaminação da segunda camada de cal hidratada

O desafio da hidratação quando se trabalha com placas de fibrobarro é a capacidade higroscópica das fibras que faz com que o compósito rapidamente fique hidratado o que, em excesso, pode amolecer a placa podendo enfraquecêla ao ponto de comprometer a estrutura e quebrá-la. A solução, nesses casos, seria um banho impermeabilizante das fibras.

A aplicação das camadas de cobertura (Figura 55) de todos os tipos em todas as placas seguiram basicamente o mesmo processo: hidratação, aplicação da pasta hidratada e novamente hidratação suave para tentar amenizar a secagem. A segunda seguiu o mesmo procedimento sendo que a única diferença foi a diminuição em mais de $50 \%$ da quantidade de cal hidratada aplicada.

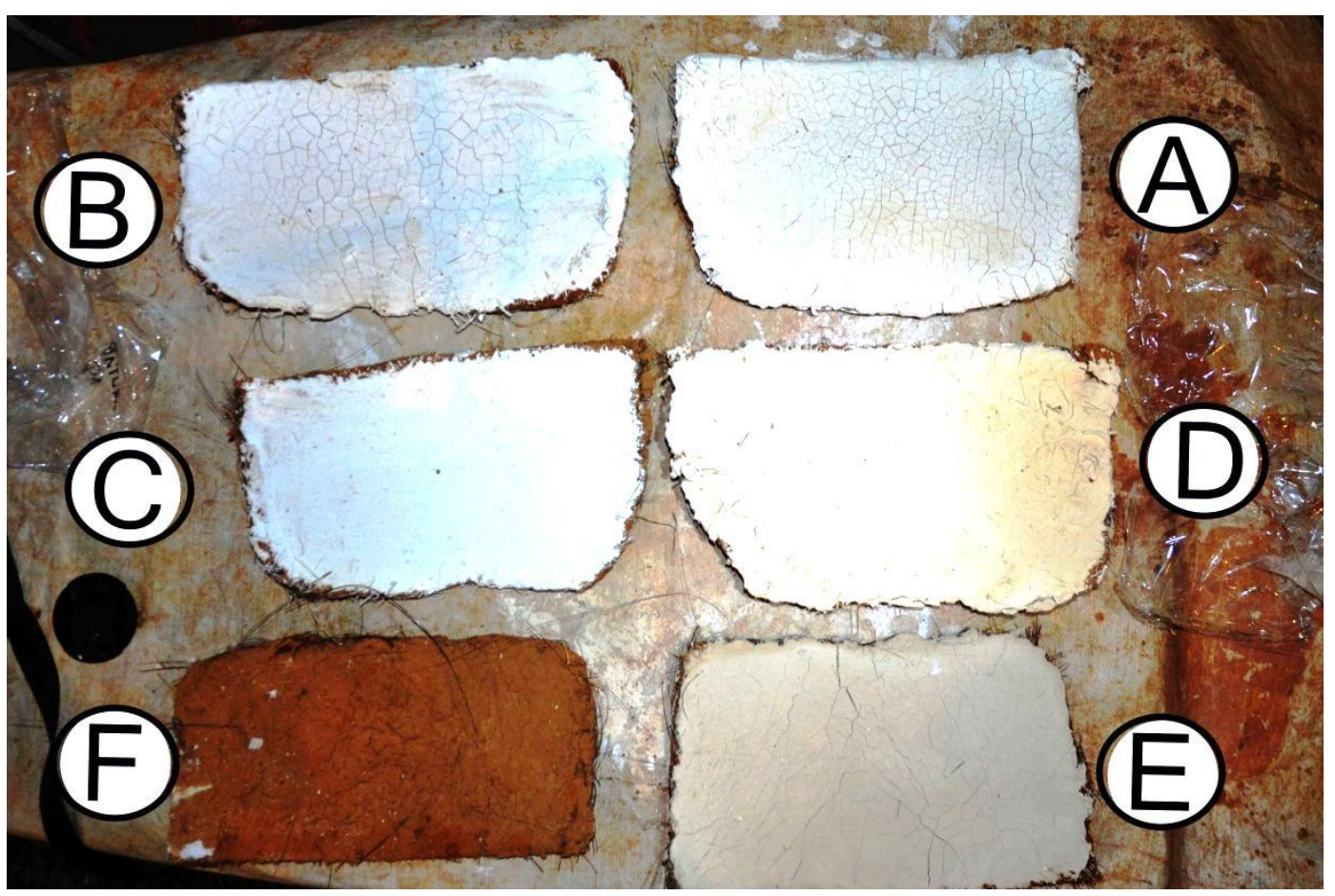

Figura 55 - Placas cobertas com diferentes tipos de cal hidratada. A placa "F" não recebeu camada de cal. 
Na terceira e quarta camada, a espátula de plástico foi substituída por pincéis (Figura 57) que aplicaram a cal hidratada de modo semelhante às etapas anteriores, $O$ interessante foi observar que a cada aplicação de uma nova camada as fissuras foram diminuindo de tamanho ao ponto de na última camada não haver mais fissuras. $O$ intervalo entre as aplicações variava entre 30 minutos e 24 horas. O que determinava era que a secagem da camada anterior não podia estar completamente seca.

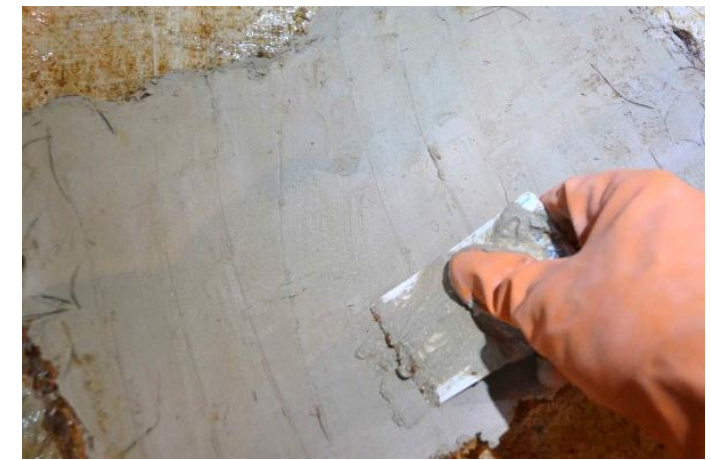

Figura 56 - Aplicação de camada com espátula

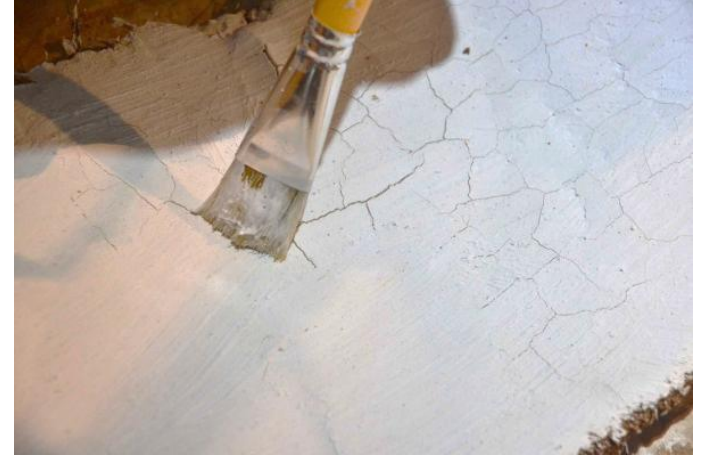

Figura 57 - Aplicação com pincel

As amostras do tipo A e B (Figura 59 58) apresentaram pequenas fissuras homogeneamente distribuídas de 1 a $2 \mathrm{~cm}$ por toda a placa. Já as placas C, D e (d'Almeida 2009) E (Figura 599) apresentaram trincas, mais profundas e espaçadas, após 12 horas da aplicação.

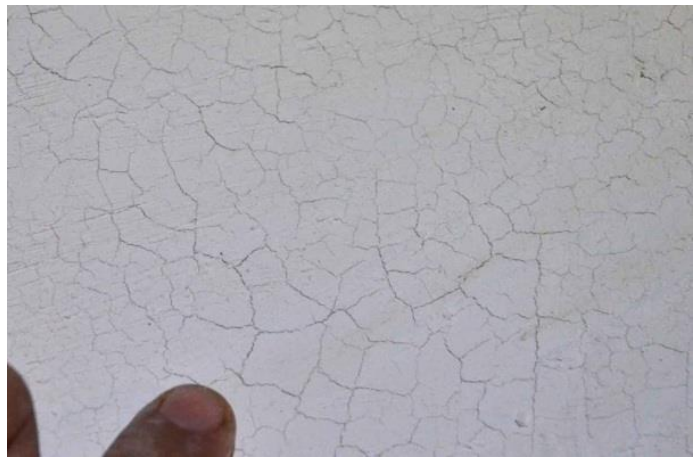

Figura 59 - Pequenas fissuras nas amostras A e B

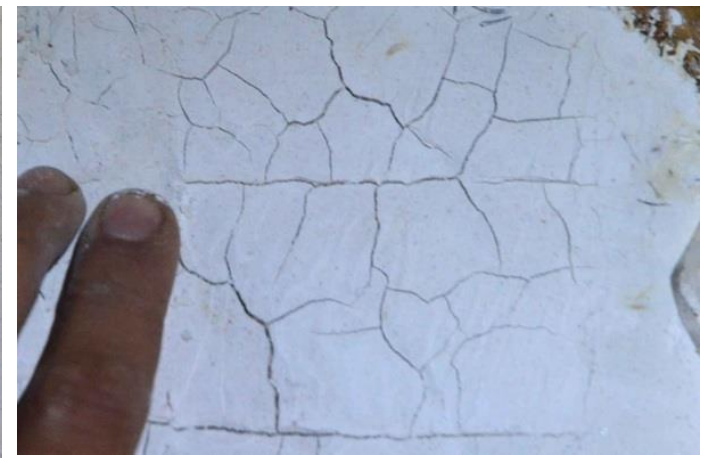

Figura 58 - Trincas surgidas nas amostras C, D e E

\subsection{Testes de permeabilidade à água estática}

Visando perceber a estanqueidade das camadas de capeamento, finas e grossas, fizemos testes de estanqueidade estática utilizando água. Para controlar a quantidade de água, foram feitas bordas utilizando argila e massa de 
modelar para conter, mesmo que provisoriamente, uma pequena quantidade de água. O procedimento foi colocar a água e simultaneamente, observar a estanqueidade. Periodicamente, sempre que o nível de água diminuía, por motivo de algum vazamento ou algo do gênero, o nível inicial de água era reestabelecido (Figura 60).

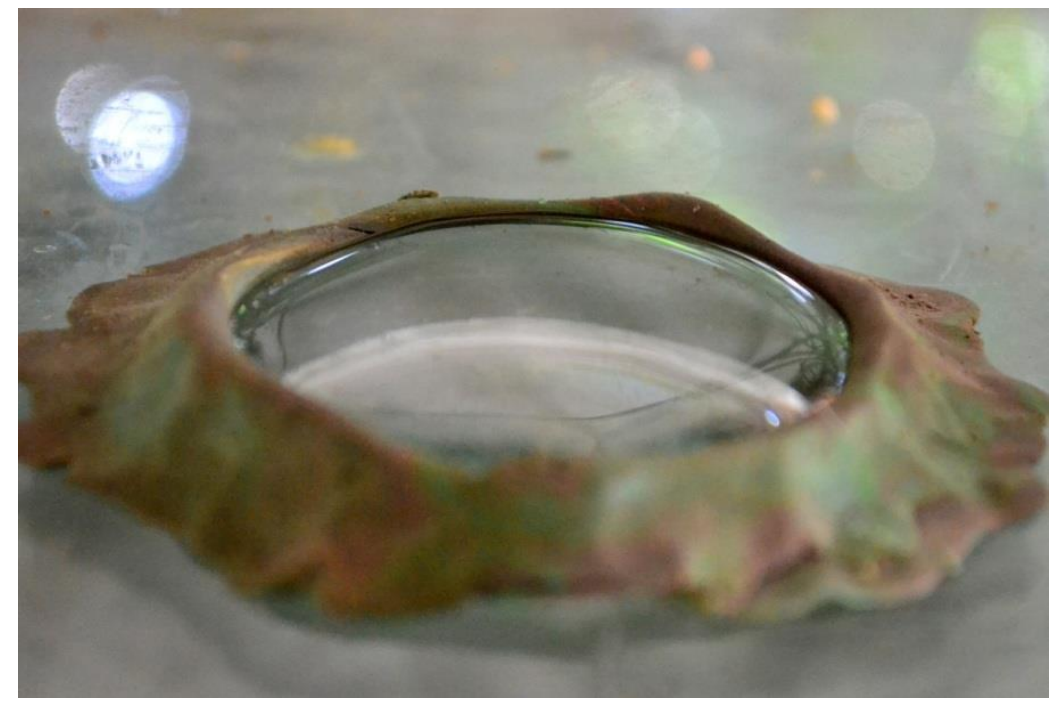

Figura 60- Teste sobre vidro do retentor de água.

Algumas superfícies cobertas com película fina de cola PVA e resina de mamona pareciam ter absorvido muita pouca água. No final do experimento chegamos até a pressionar as esferas na região hidratada e nada aconteceu (Figura e Figura 62 ).
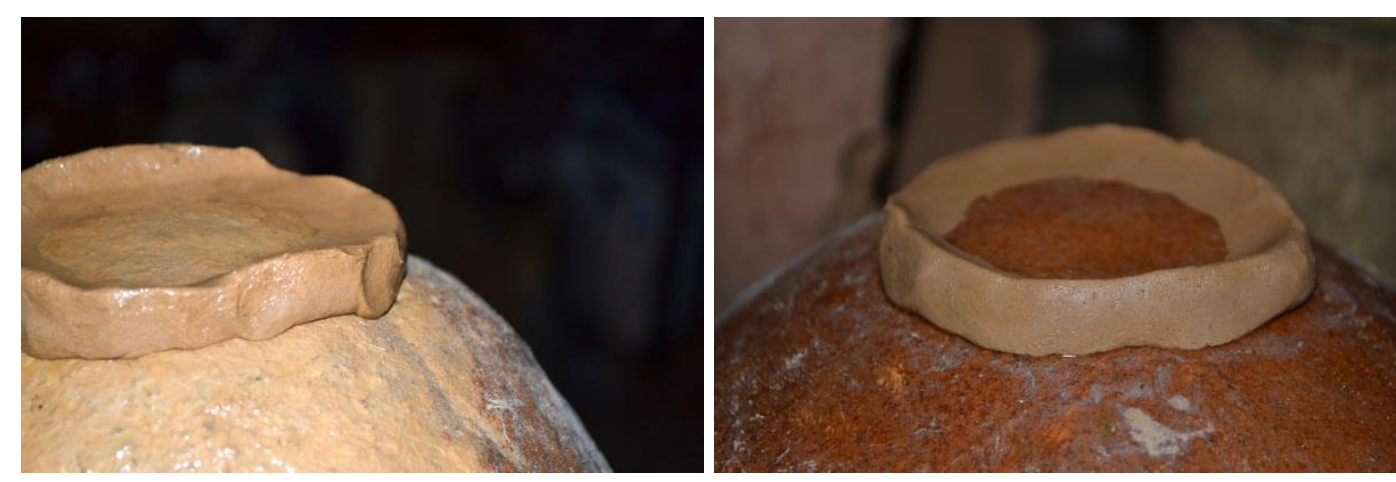

Figura 62 - Cobertura de PVA sendo testada com água
Figura 61 - cobertura de resina de mamona. Ambas não aparentaram sofrer efeitos da

Praticamente a mesma situação ocorreu com as amostras cobertas com pasta de cal hidratada (pura ou com barro) (Figura 63). A diferença é que a cal parecia absorver a água colocada lentamente (Figura 64). Foi feito o teste de 
pressionar a parte hidratada e tudo pareceu inalterado. O mesmo não ocorreu com outros experimentos.

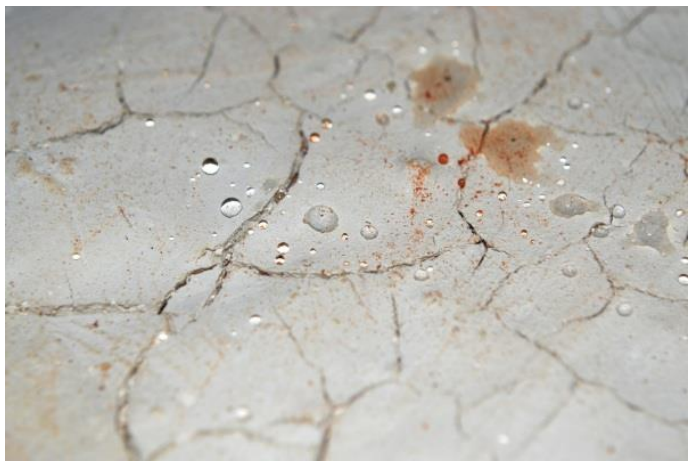

Figura 64 - Cal hidratada logo no início parecia não absorver a água.

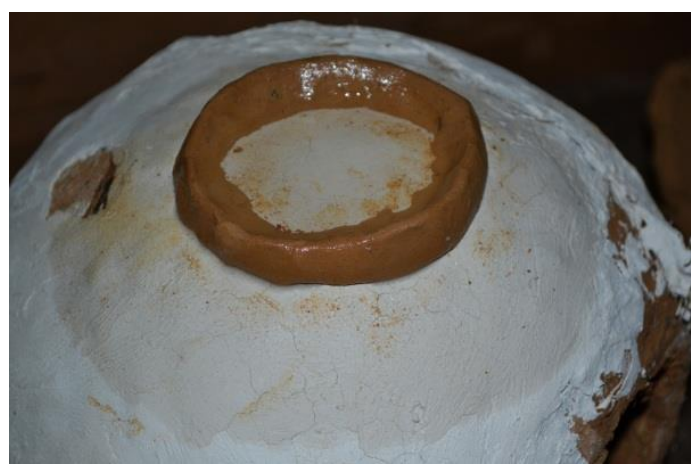

Figura 63 - Lentamente a água era absorvida e "distribuída" pela superfície. Internamente não notamos diferença.

Nas amostras cobertas com cal hidratada misturada com solo (razão de 1:1), com fibras e sem fibras, foi notado que este período de "tolerância" não acontecia. A água parecia ter sido absorvida pelo compósito quase que imediatamente (Figura 65). Foi ponderado que a camada mista barro e cal era útil como camada intermediária entre a estrutura básica e a camada de superfície mais externa ajudando assim na união de ambas. Ou então, poderia ser um facilitador para pinturas de paredes já que, como visto no capítulo anterior, Mendes (2010) relata que a monocromia do branco foi uma das críticas ao modelo construtivo brasileiro na época da chegada da Família Real no Brasil.

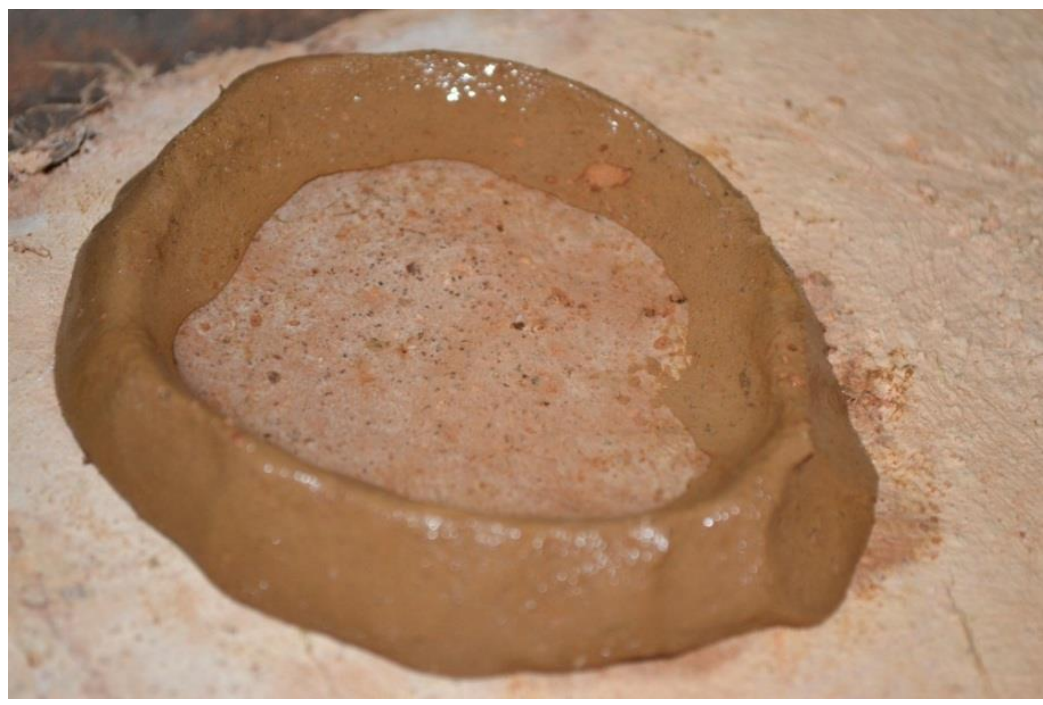

Figura 65 - Amostra de cal com barro misturados sobre placa curva. 
Para servir de parâmetro, entre os experimentos existia uma amostra que não recebeu qualquer capeamento e outra que recebeu uma película fina de cal hidratada na antevéspera. Ambas quebraram sem qualquer ação visível depois de cerca de 13 e 18 minutos, respectivamente (Figura e Figura 67 ). Esta quebra já era esperada na amostra sem qualquer proteção, mas não muito na amostra com a película fina. É possível que a película não tenha tido área o suficiente para absorver e distribuir a água. O que também pode ter ocorrido é que não se tenha dado o tempo para secagem da camada.

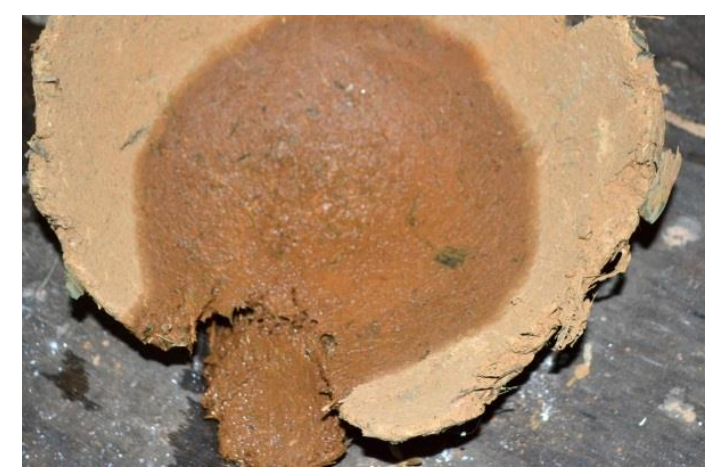

Figura 67 - Placa de argila pura que cedeu em poucos minutos.

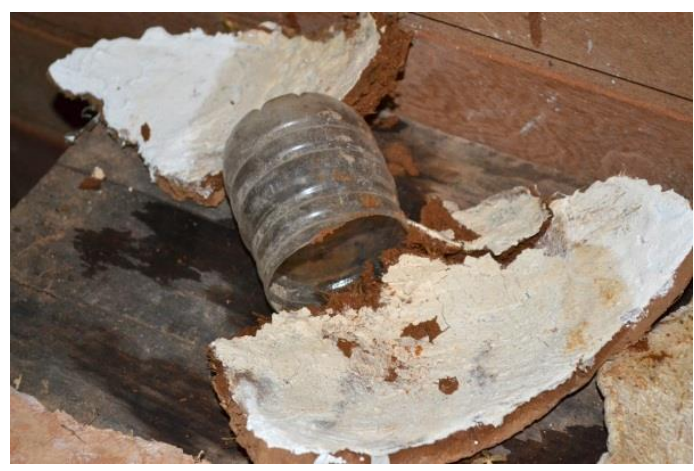

Figura 66 - Placa com película de cal feita 2 dias antes do experimento.

$\mathrm{Na}$ esfera coberta com mucilagem de cactos misturada com terra, após um período de 30 minutos, teve efeitos similares aos da camada de pastacal (Figura 69 8). Contudo, ao fazer pressão sobre o material este cedeu na parte hidratada. Olhando a parte interna, foi possível notar uma mancha mais escura ao redor do local onde a água ficou (Figura 9). É possível afirmar que o material resistiu à ação da água e talvez, se não houvesse ação humana, teria secado e o efeito não seria perceptível. Depois deste experimento é possível supor que em contextos de poucas chuvas ou com manutenção constante este tipo de tratamento pode ser muito pertinente, principalmente, pelo seu baixo custo quando disponível na localidade. 


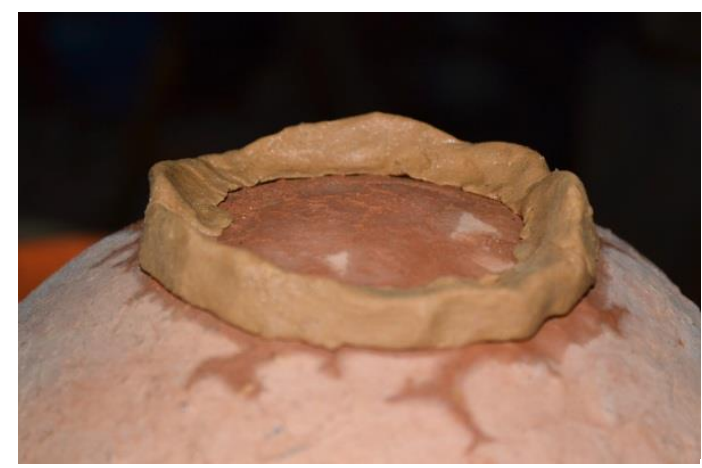

Figura 69 - Teste sobre esfera com película de mucilagem de cactos palma.

Para estes testes foram utilizadas

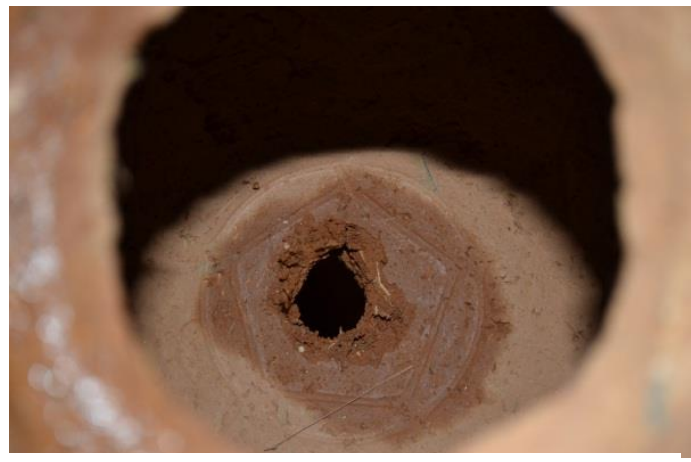

Figura 68 - Depois de ceder, foi percebido que a película de cobertura permitia a passagem da água para a parte interna.

coberturas. As esferas utilizadas tinham, na medida do possível, as mesmas dimensões e proporção entre os componentes. Quatro destas esferas tinham cobertura na parte externa. Apenas uma tinha amostra fina de cal hidratada na parte interna (Figura 70).

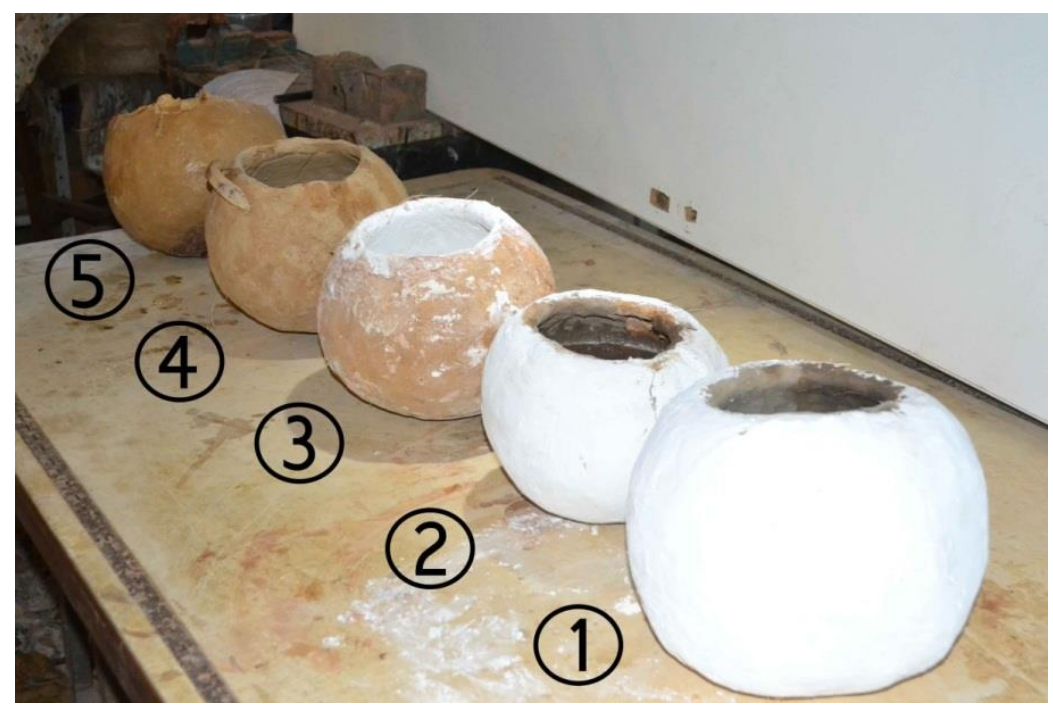

Figura 70 - Esferas testadas perfiladas

Tabela 2- Componentes de capeamento de cada esfera

\begin{tabular}{cl}
\hline Amostra & Camada de capeamento \\
\hline $\mathbf{1}$ & Camada externa de Cal com fibras $(0,5 \mathrm{~cm})$ \\
$\mathbf{2}$ & Película $(2 \mathrm{~mm})$ de cal hidratada externa \\
$\mathbf{3}$ & Película $(2 \mathrm{~mm})$ de cal hidratada interna \\
$\mathbf{4}$ & Sem qualquer componente \\
$\mathbf{5}$ & Cola de PVA na parede externa \\
\hline
\end{tabular}


Neste segundo teste de estanqueidade, ao depositar a água na parte interna das esferas que não possuía qualquer proteção foi possível observar outros comportamentos que não foram possíveis de se visualizar no primeiro teste. Em todas as esferas foram colocadas $700 \mathrm{ml}$ de água.

\subsubsection{Esfera com PVA e esfera sem qualquer revestimento}

A esfera com cola PVA na parede externa (esfera 5) com 17 minutos começou a apresentar manchas pontuais. Aos 62 minutos todo o líquido da esfera começou a sair a partir de um ponto próximo à base (Figura 71). Este buraco de $6 \mathrm{~mm}$ que se abriu não comprometeu a estrutura global, que permaneceu inalterada.

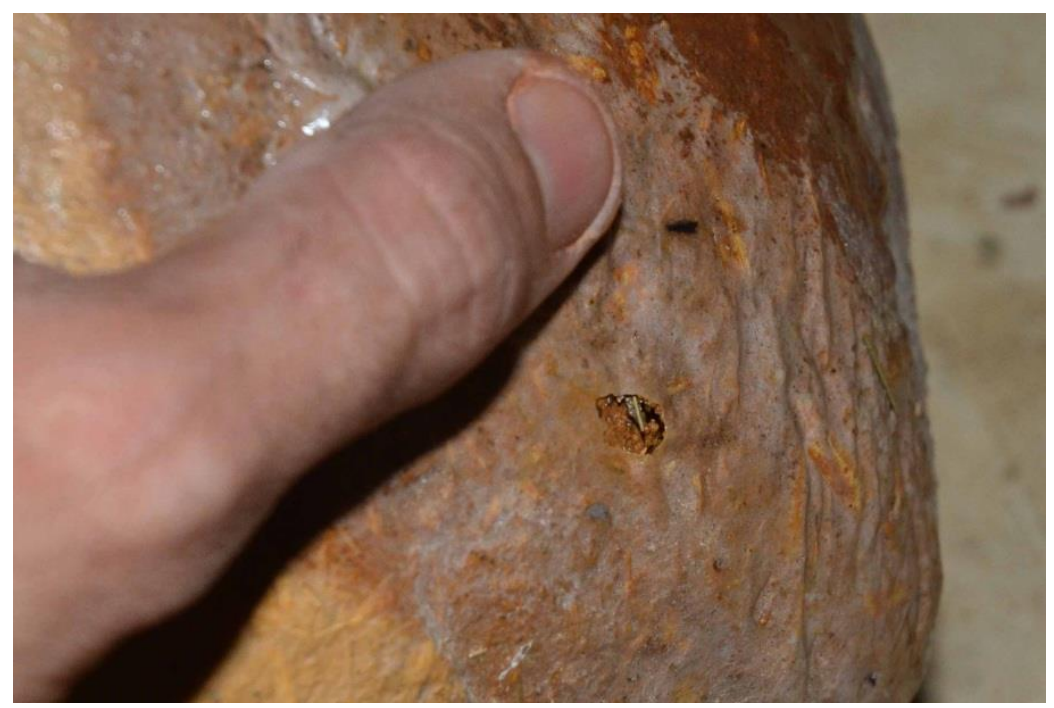

Figura 71- esfera coberta de cola pva rompeu com uma hora de experimento.

Em um período de 30 minutos, a água transpassou da parte interna da esfera para a parte externa até encontrar uma barreira que a conteve. A Figura 72 ajuda a imaginar que a água acumulou entre a esfera e a película de cola PVA. A água espalhou-se até encontrar um ponto onde a cola estava mais diluída ali perfurou a esfera, colocando fim ao experimento. 


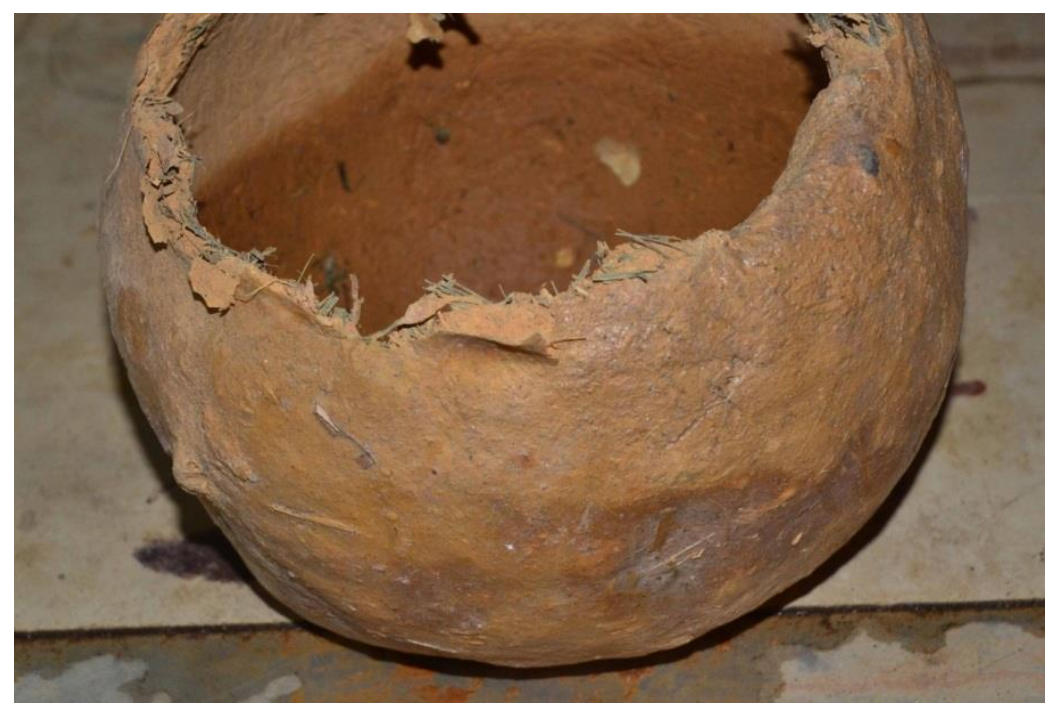

Figura 72 - Esfera 5 com manchas de absorção de umidade por dentro e por fora.

A esfera 4, que não recebeu qualquer tipo de tratamento, com 15 minutos de experimento apresentou uma pequena mancha próxima à base. A partir de 30 minutos de experimento já apresentava pequenas manchas surgindo no hemisfério inferior da parte externa (Figura 73). Estas manchas já tinham cerca 1-1,5 cm de diâmetro. Elas foram aumentando gradativamente (Figura 74) até que, aos 75 minutos de experimento a esfera rachou na base e todo o líquido começou a escorrer.

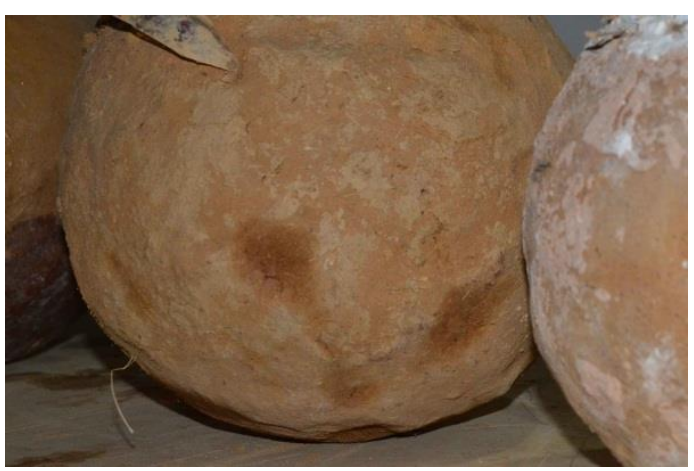

Figura 73 - Esfera 4 com 30 minutos de experiência

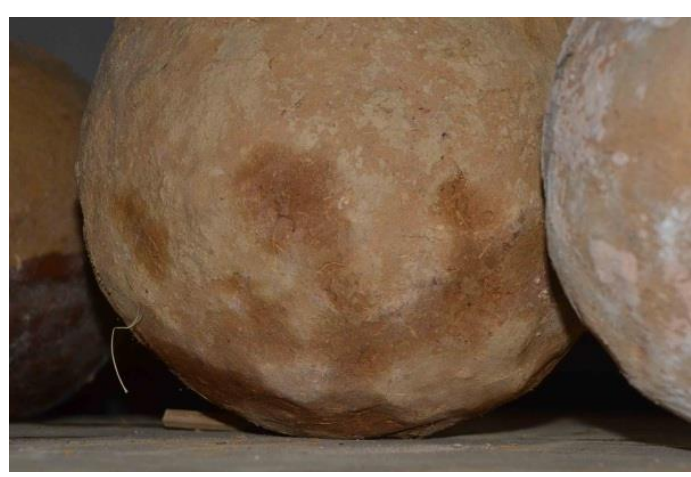

Figura 74 - Esfera com 60 minutos de experiência 
O vazamento da água evidenciou a falha estrutural da esfera que ficou inutilizada (Figura 75). O acúmulo de água amoleceu o barro que se desprendeu das fibras.

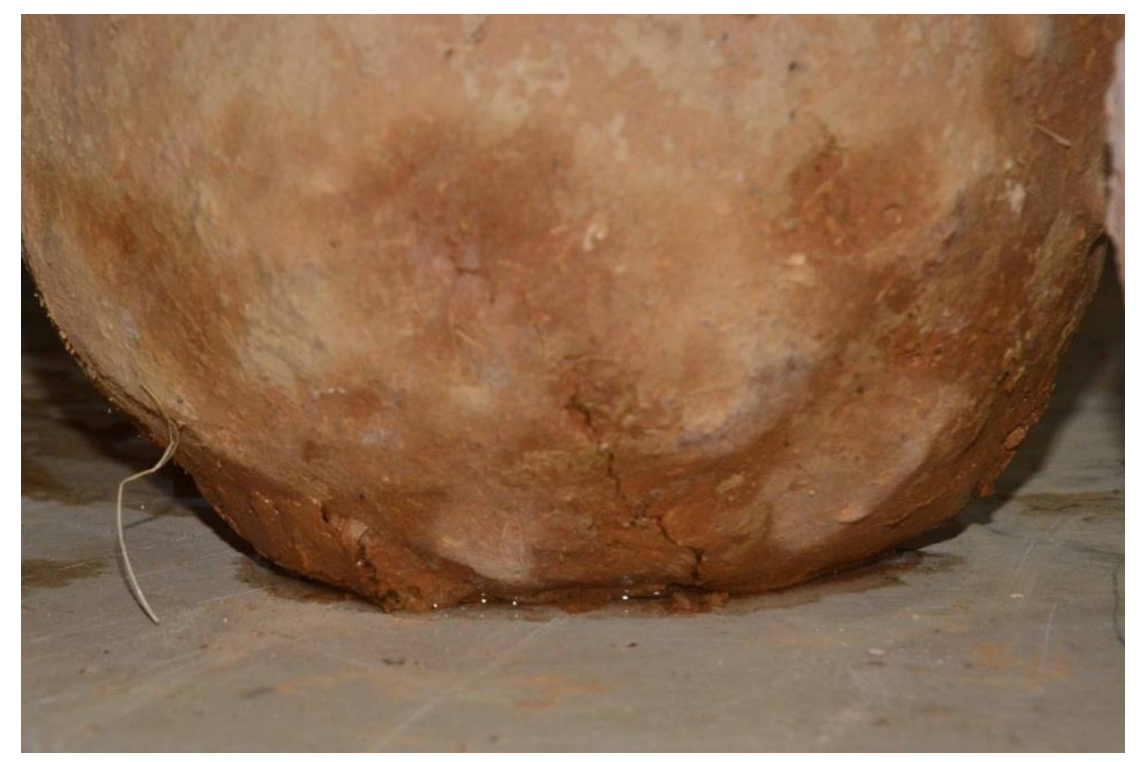

\section{Figura 75 - Detalhe do abalo estrutural da esfera 4}

Foi analisado que apesar da esfera 4 ter dado sinais da transposição da água para a parte externa antes da esfera 5 , a esfera 4 durou mais porque conseguiu jogar para o ambiente parte da umidade que ficou retida na esfera 5 . Outra possibilidade foi a qualidade das fibras. Ambas haviam sido feitas com fibras de grama, mas a esfera 5 havia sido feito há mais tempo que esfera $4 \mathrm{e}$ por isso, talvez, suas fibras estivessem mais frágeis. $O$ fato da esfera 5 ter mantido sua coesão enquanto a 4 se desfez pode ter sido causado pela película de PVA, que ajudou a estrutura a manter sua forma e também porque a esfera 4 ficou mais tempo em contato com a água.

\subsubsection{Esferas com Cal hidratada}

As esferas 1, 2 e 3 apresentaram comportamento tão curioso que o relato é um item à parte. As esferas 1 (cal com fibras na parte externa) e 2 (película na parte externa) com 14 minutos de experimento já apresentavam manchas em sua superfície (Figura 77 ). As manchas na esfera 1 eram maiores do que as da esfera 2. Provavelmente isso ocorreu porque as fibras da esfera 1 auxiliaram a conduzir a água para a parte externa. 


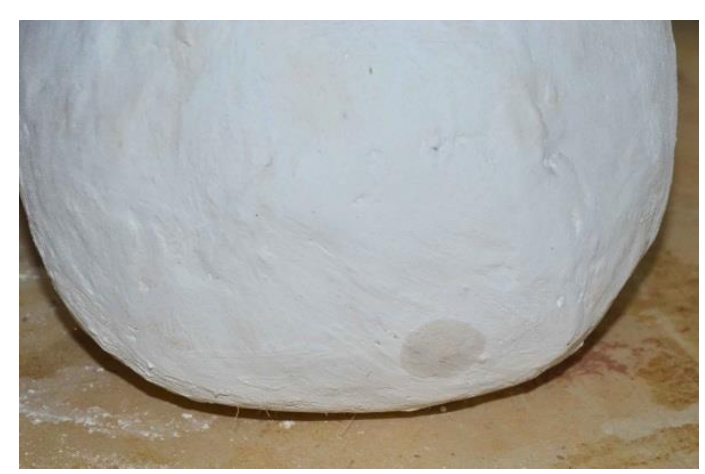

Figura 77 - Esfera 1 com 14 minutos de experimento

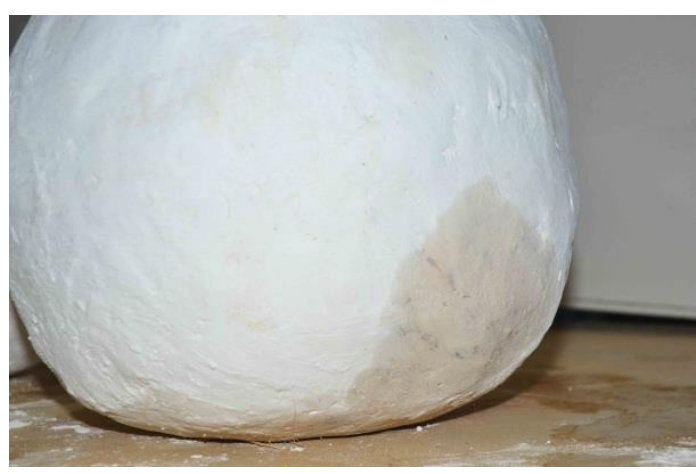

Figura 76 - Esfera 1 com 30 minutos de experimento

Estas manchas foram aumentando gradativamente mesmo quando as outras esferas ainda pareciam pouco afetadas. Aos 36 minutos a esfera 1, por exemplo, apresentava coloração mais escura por grande parte da sua superfície (Figura) enquanto a esfera 4 (sem camada protetora) apresentava pequenas manchas (Figura 73).

Aos 75 minutos de experimento, quando a esfera 4 vazou, uma pequena quantidade de água era visível na base da esfera 1 (Figura 79) mas não notamos o nível da água diminuir como em um escoamento por vazamento. Parecia que apesar de ser mais espessa em $2 \mathrm{~mm}$, a esfera 1, que as fibras, colaboraram na fácil condução da água até a superfície da esfera.

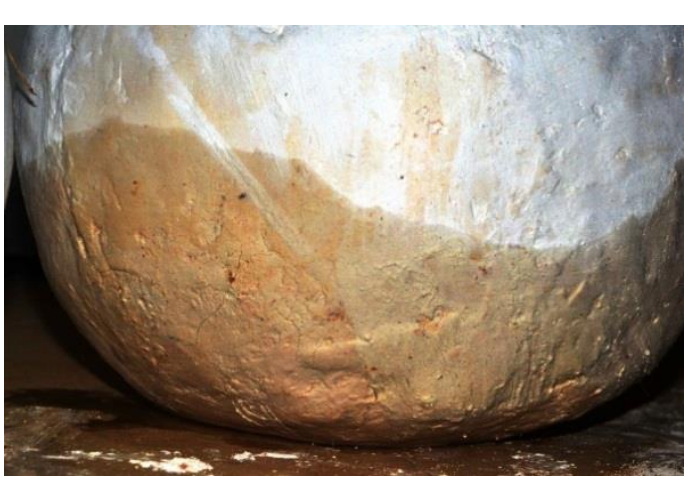

Figura 79 - Água brotando da base da esfera 1. A foto foi equalizada nas cores para realçar

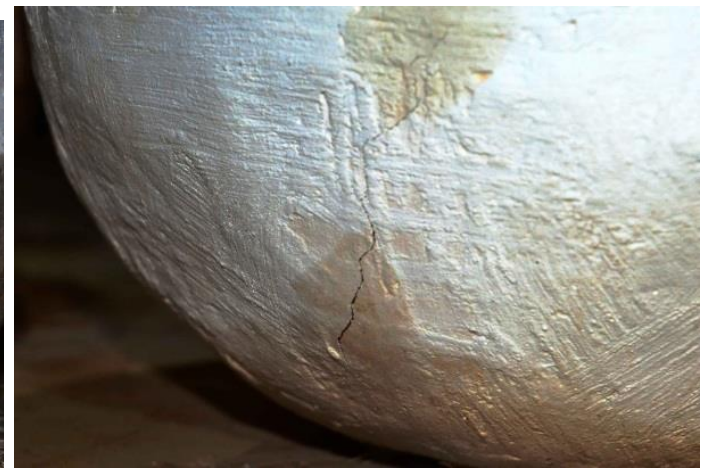

Figura 78 - Esfera 2 apresentando fissuras

A esfera 2 não apresentou pequena quantidade de água na sua base mas assim como a esfera 1, aos 116 minutos de experimento, apresentou fissuras nas camadas de cal hidratada (Figura 79). 

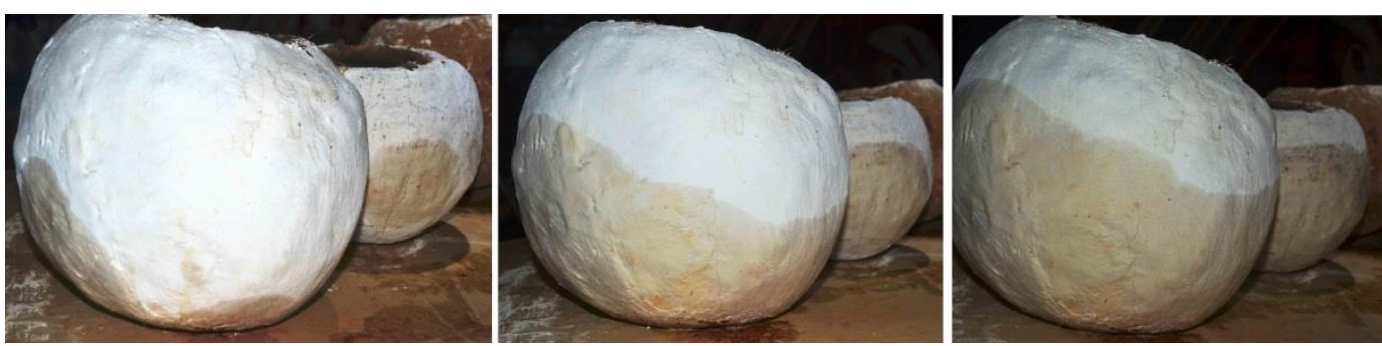

Figura 80 - Sequencia de crescimento da mancha de água

Como é possível observar na Figura 80 o crescimento da mancha úmida foi gradualmente subindo por capilaridade, acima do nível da água de enchimento.

Com mais alguns minutos, provavelmente, as duas iriam vazar, o experimento precisou ser interrompido com 135 minutos. Ao final do experimento, ambas as esferas, mantiveram a sua estrutura apesar do tempo de estanqueidade estática á agua.

A esfera 3, por ter uma camada de cal hidratada dentro da esfera, também apresentou muitos dados interessantes. O primeiro foi que apesar de todas as esferas terem recebido a mesma quantidade de água e terem a capacidade para aproximadamente o mesmo volume, a quantidade de água depositada parecia diferente (Figura 81 e Figura 82). Aos 17 minutos do início do experimento a esfera 3 apresentava um nível de água abaixo das demais.

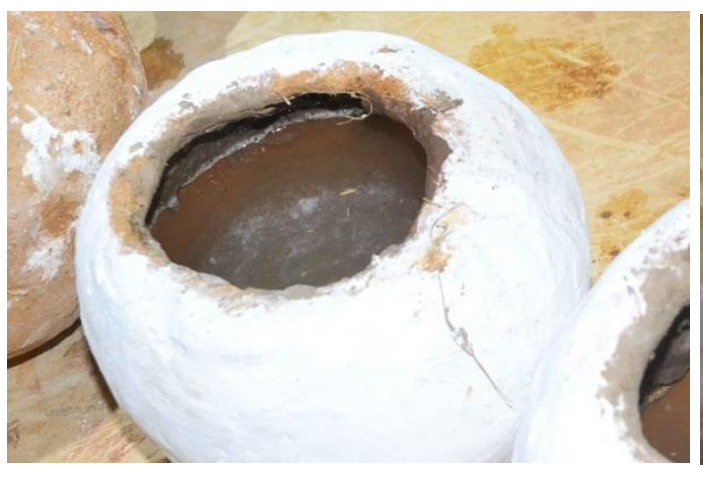

Figura 81 - Nível de água da esfera número 2

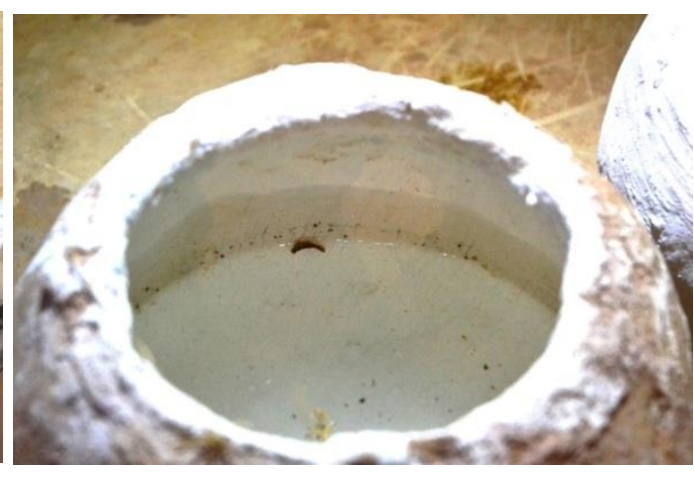

Figura 82 - Nível de água da esfera número 3

Outra particularidade da esfera 3 é que ela foi a última demonstrar os efeitos da passagem de água na parede externa (Figura 84 3). Isto só foi ocorrer quando o experimento já tinha 88 minutos de duração (Figura 84 4). Quatro minutos antes o interior das esferas 1, 2 e 3 foi tocado e era perceptível ao tato, que o interior da esfera 3 ainda mantinha uma superfície rígida enquanto as demais davam claros sinais de amolecimento do interior, um resultado esperado. 


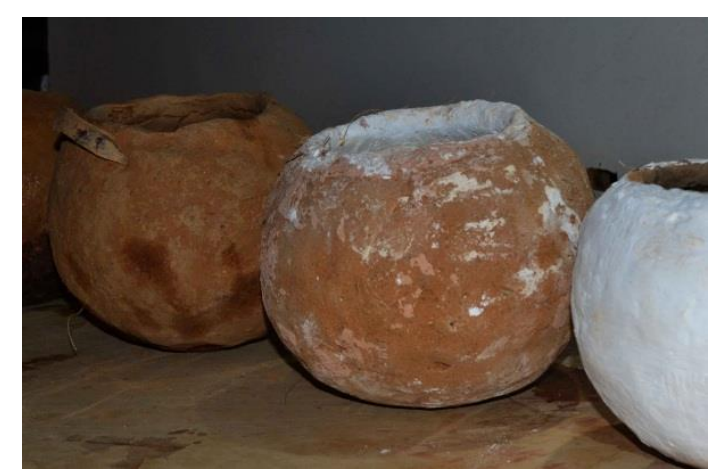

Figura 84 - Esfera 4 já dava sinais de passagem da água enquanto a esfera 3 ainda parecia intacta.

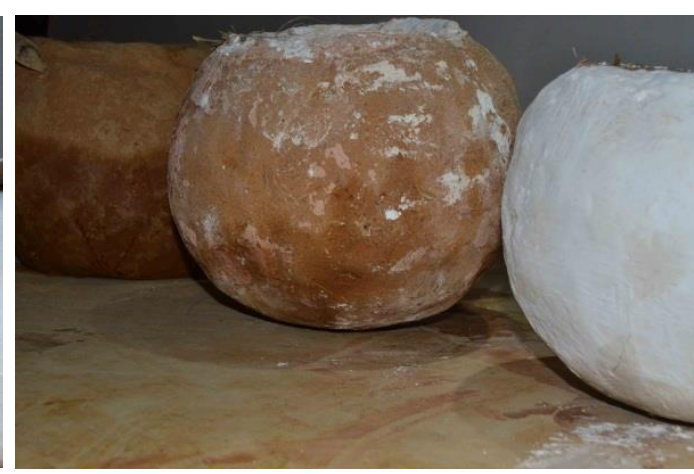

Figura 83 - Esfera 4 já havia se rompido quando a esfera 3 começou a demonstrar sinais da higroscopia

Ao final do experimento recolhemos as águas dos três experimentos e notamos que a água da esfera 3 apresentava uma coloração esbranquiçada (Figura 85) enquanto as outras, como era de se esperar tinha coloração de terra (Figura 86). As esferas voltaram a ter o aspecto anterior ao experimento e, aparentemente, com as mesmas características mecânicas.

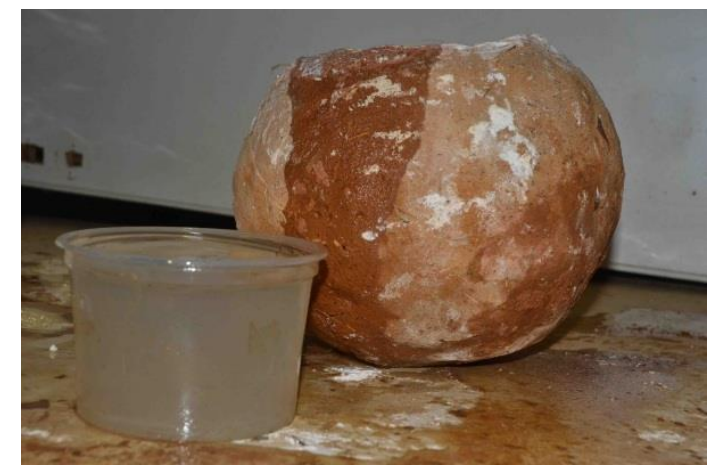

Figura 85 - Água resultante da esfera 3

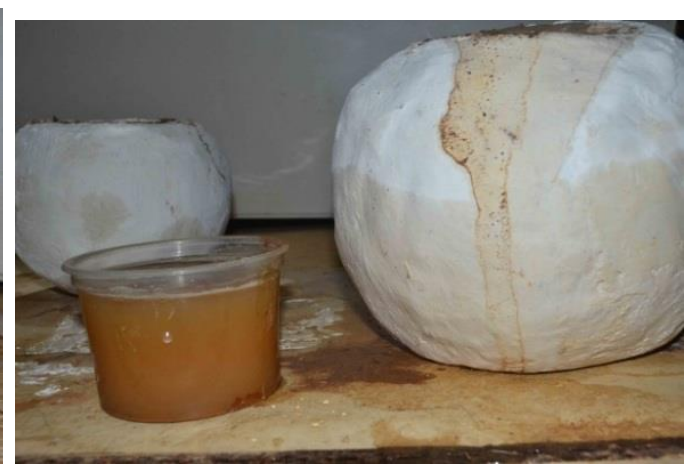

Figura 86 - Água resultante da esfera 1

O fato da nível de água da esfera 3 ter diminuído sem que a transposição para a parte externa fosse visível corrobora a tese de que a cal hidratada absorve a água e a retém. Nesse processo, a cal impermeabiliza ou, pelo menos, aumentando o tempo de transposição da água para a parede externa em relação ao barro cru.

O ocorrido com as esferas 4 e 5 , converge com o que Snell \& Callahan (2009) dizem. Eles relatam que a água, por ser um solvente universal, sempre encontra um meio de escoar e, quando acumula, pode causar danos à estrutura. Por isso deve-se considerar materiais de capeamento que permitam permeabilidade deste elemento. 
A experimentação com as esferas foi de encontro ao que é relatado por Rascusin \& McArleton (2012) de que deve-se pensar que os lados extremos das camadas múltiplas deve ter porosidade semelhanter para que a umidade não fique presa nas camadas centrais. 


\section{Aplicação da Pesquisa - Estudos de Caso}

Ao longo dos meses em que esta dissertação foi desenvolvida, a pesquisa dentro do LILD foi feita quase que simultaneamente com experimentações em laboratórios de campo. Neste capítulo serão descritos os exemplos de aplicação da pesquisa em contextos sociais. Com as pesquisas de campo, mais do que desenvolver técnicas, foram desenvolvidas relações com os usuários, sua ação construtora, motivação pessoal e como isso influencia no processo de apropriação da tecnologia e o resultado final.

A pesquisa experimentou realizar a construção de alguns objetos arquitetônicos com o apoio de pessoas de diferentes contextos sociais, com variados ritmos e motivações de trabalho. Mais do que a ordem cronológica, o as experiências foram organizadas de acordo com o contexto e com os conhecimentos desenvolvidos.

O motivo pela opção de construir junto com outras pessoas encontra referência em Cunha (2009), quando este relata que as construções, individual ou coletiva, grande ou pequena, serviam como pequenas escolas onde os mais jovens aprendiam "com a própria contribuição no trabalho coletivo e sobretudo, com a observação continuada no trabalho do outro mais experiente." (Cunha, 2009. Página 48). O autor ainda continua dizendo que a oportunidade de aprender era aproveitada quando havia curiosidade para se aprender conhecimentos sutis, praticamente imperceptíveis, dos gestos e atitudes daqueles que detinham a sabedoria do fazer. Em alguns casos que abordados os "mestres" foram os próprios materiais "moldados pela ação direta do ar ou da água" (Cunha, 2009. p. 49 ).

$\mathrm{Na}$ ação coletiva, até mesmo os mais inexperientes nos ajudaram a criar reflexões sobre os precedimentos gestuais. A partir da ação dos indivíduos e da observação do seu fazer conseguimos perceber possibilidades de ação e interação com os materiais no processo construtivo.

\subsection{Parabolóide de dupla curvatura}

Uma das primeiras experiências coletiva foi a construção de um parabolóide de bambu e cordas idealizada pelo professor Daniel Malaguti 
Campos. A construção básica consistia em 10 bambus de $2,5 \mathrm{~m}$ amarrados e organizados, formando um parabolóide (Figura 87).

Sobre esta estrutura foram amarradas ripas de bambu de aproximadamente $2 \mathrm{~cm}$ de largura. $\mathrm{O}$ objetivo desta construção era a de se tornar uma cobertura anexa ao LILD.

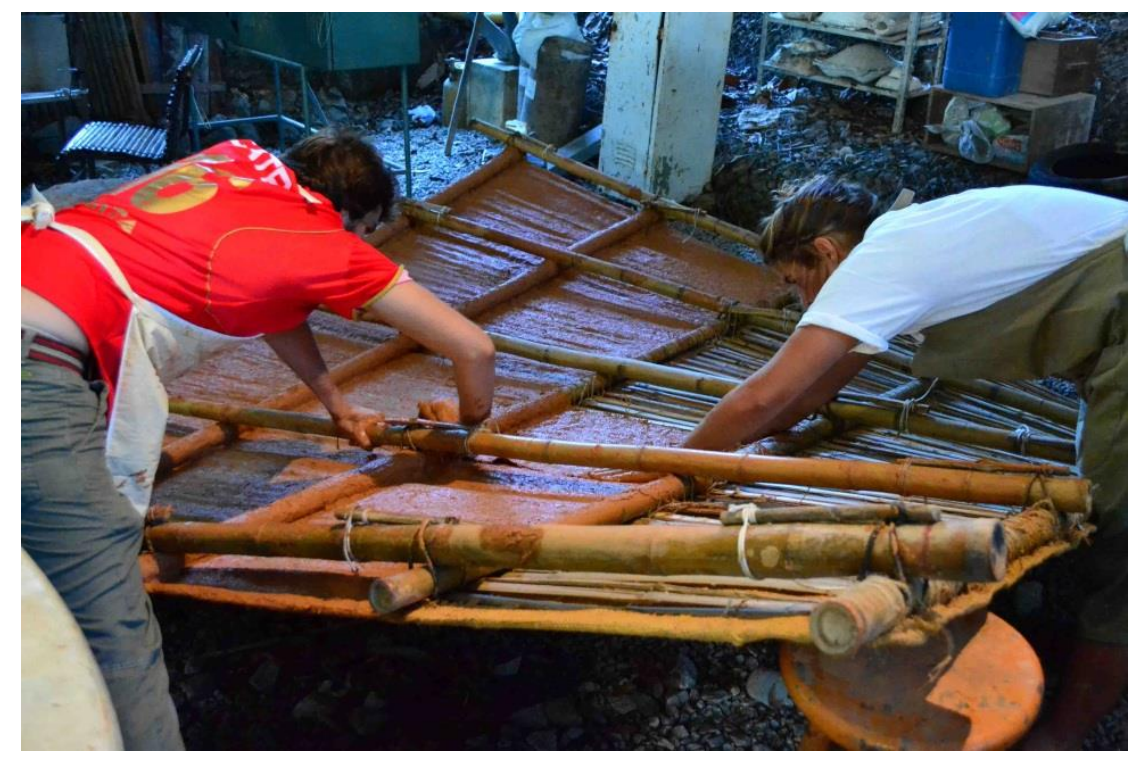

Figura 87 - Estrutura paraboloide

\subsubsection{Camada feita por tecido de juta e barro}

Quando a presente pesquisa iniciou-se, a estrutura estava começando a receber as mantas de juta-barro para vedação. A intenção da investigação foi de, ao anexar o barro de cada lado da estrutura, que esta protegesse o bambu da ação de brocas e carunchos. A etapa seguinte seria a experimentação de diferentes tipos de camadas de cobertura para proteger o barro da ação erosiva da chuva.

A metodologia de preparo das mantas era de hidratar o tecido para facilitar a recepção ao barro (Figura 89 ). As práticas haviam ensinado que o tecido seco absorvia a água do barro e este perdia grande parte de suas propriedades moldáveis antes da manta poder ser aplicada. 


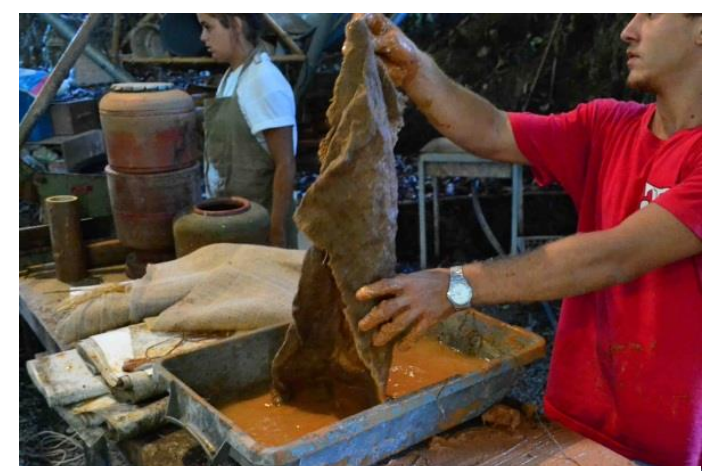

Figura 89 - Hidratação do tecido antes da mistura com o barro.

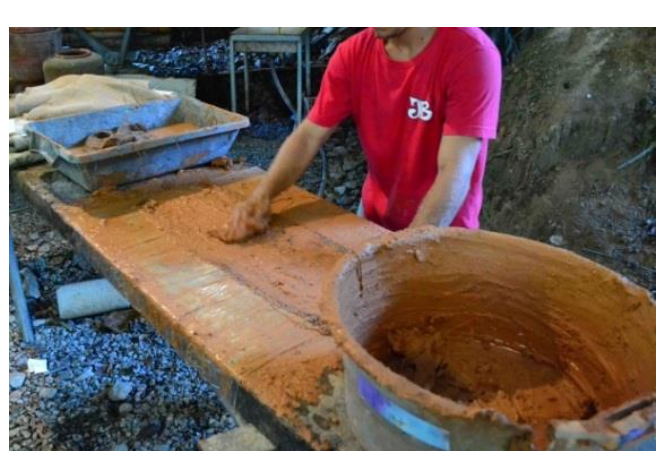

Figura 88 - Gestual para incorporação do barro no tecido.

A aplicação do barro era feita através de gestos manuais que pressionavam o barro a fixar no tecido formando o compósito juta-barro (Figura 89 - Hidratação do tecido antes da mistura com o barro.

). Em seguida este era aplicado à superfície da parábola. Em algumas bordas eram cortados tiras com uma tesoura para a integração do compósito à estrutura (Figura 91 e Figura 91 - Uso da tesoura para ajudar a manta a se fixar na estrutura.). Novamente gestos manuais pressionavam o tecido para ajudar este a se fixar no paraboloide.

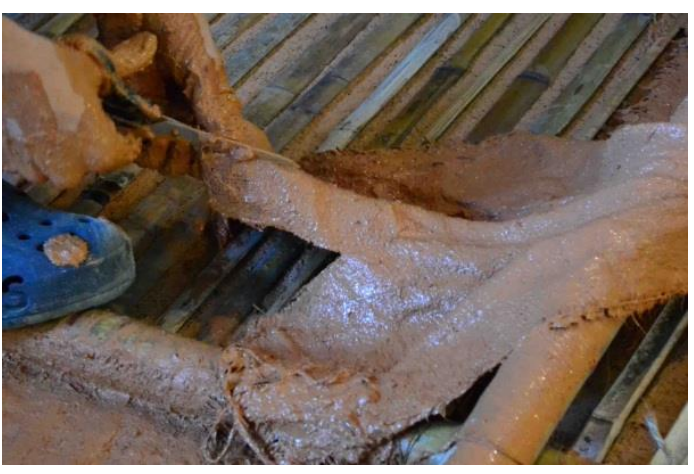

Figura 91 - Uso da tesoura para ajudar a manta a se fixar na estrutura.

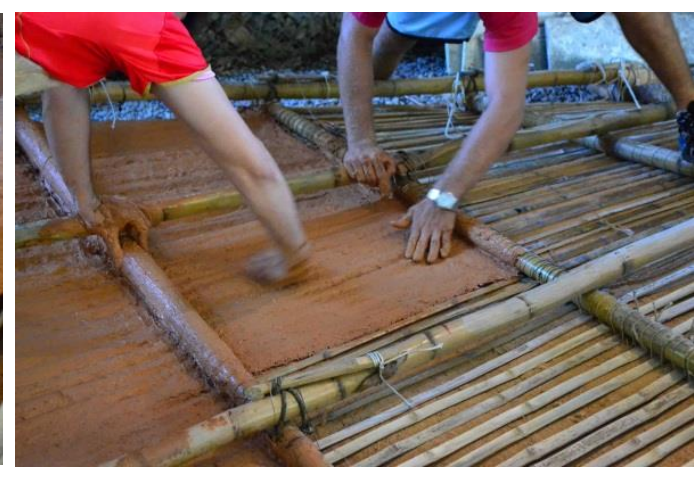

Figura 90- Dedos e mãos pressionando o compósto para este fixar na estrutura.

O uso do compósito de juta-barro tornava o trabalho leve, já que a quantidade de materiais era reduzida. Além disso, o rendimento do trabalho de cobertura era grande já que 3 pessoas podiam cobrir metade da área em pouco mais de 1 hora caso tivessem os materiais necessários (barro hidratado, tecido, tesoura) disponíveis (Figura 92). 


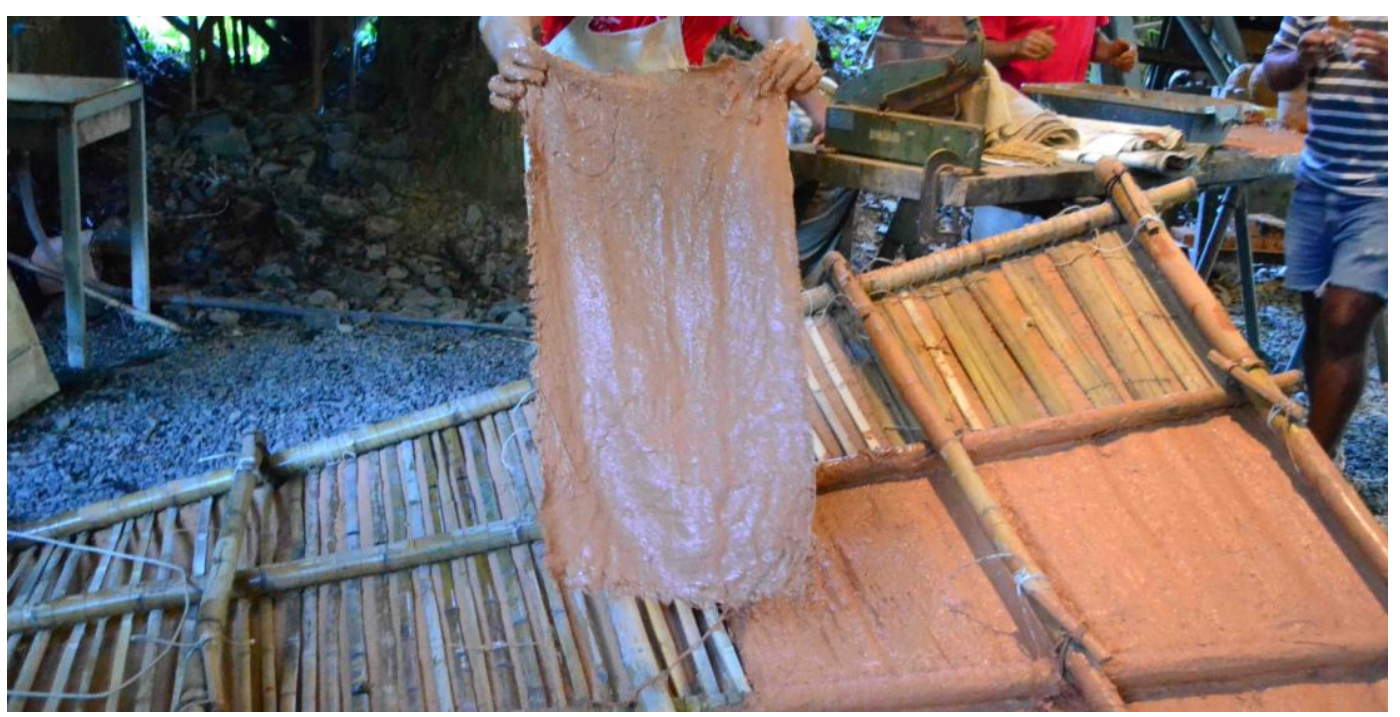

Figura 92 - Manta de juta-barro sendo posta sobre o parabolóide.

Após a aplicação da camada em um dos lados, alguns dias eram esperados para a estrutura secar. Em seguida a estrutura era girada para efetuar o mesmo procedimento do outro lado, sendo auxiliados pela gravidade na fixação das mantas.

A etapa seguinte consistiu em aplicar testes de camadas que preservassem o fibrobarro da ação da água. Inicialmente a parte inferior da estrutura foi trabalhada. Como esta camada, em teoria, não receberia ação direta da chuva, a estrutura foi dividida em 4 quadrantes e, em cada um deles, foi experimentado um tipo película de capeamento.

Em dois quadrantes a película de capeamento foi feita com cola PVA. A diferença para os dois quadrantes foi apenas o teor da diluição da cola. No primeiro, a diluição foi mínima (razão 1:2 de cola e água); já no segundo, a diluição foi um pouco maior (1:5).

Em ambos os processos foram utilizados pincéis e esponjas em movimentos horizontais ou verticais no sentido das ripas. A ferramenta utilizada que pareceu ser mais eficiente em distribuir a cola com o menor esforço foi a rolo de esponja (Figura 94 - Deterioração do rolo ao final da experimentação 3).

O rolo de espuma ficou inutilizado após o experimento. Além de deteriorar a esponja durante a colagem, o rolo de espuma absorvia pequenas pedras do compósito, o que ajudava ainda mais na deterioração da esponja. O curioso é que durante o processo de união tecido-barro, essas partículas de pedra e areia não eram percebidas. A solução seria trabalhar o com barro mais fino ou mais argiloso mas isso também aumentaria o trabalho de processamento do barro (Figura 94 4). 


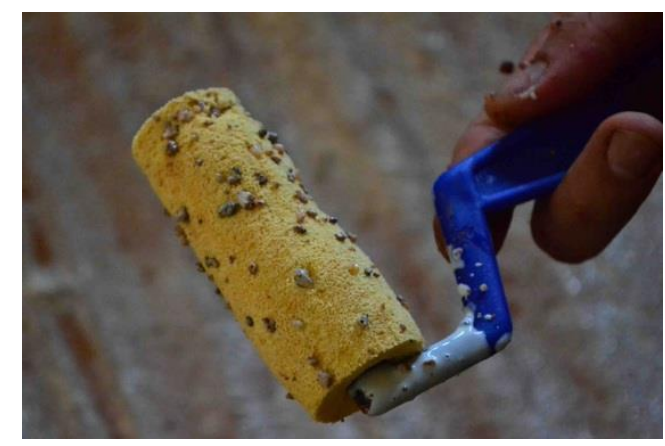

Figura 94 - Deterioração do rolo ao final da experimentação

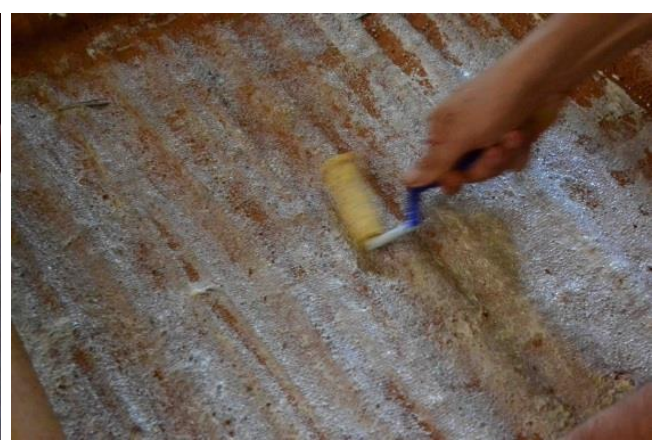

Figura 93 - aplicação da cola PVA na

Nos outros dois quadrantes foi utilizado a goma de polvilho azedo de duas maneiras distintas. Assim como nos experimentos com as esferas, a aplicação da goma foi feita da forma pura e adicionada com terra na razão 1:1. Do mesmo modo que foi feito com o experimento das esferas, as mãos foram usadas para espalhar a goma por todo quadrante (Figura 95). No processo de confecção, também foram pintados os bambus estruturais que não haviam recebido camada de juta-barro.

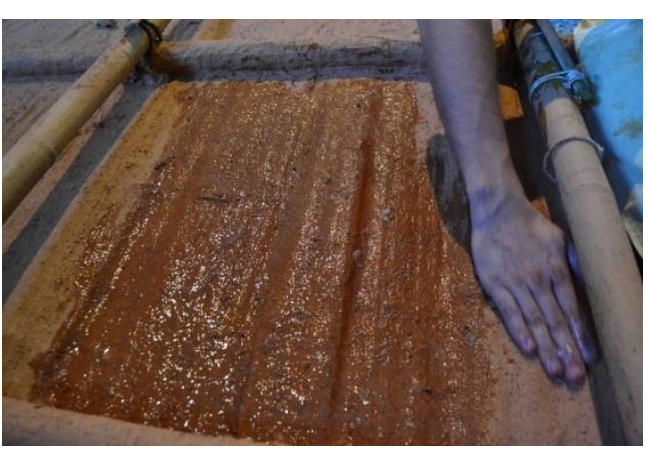

Figura 96 - Aplicação com as mãos da goma na estrutura

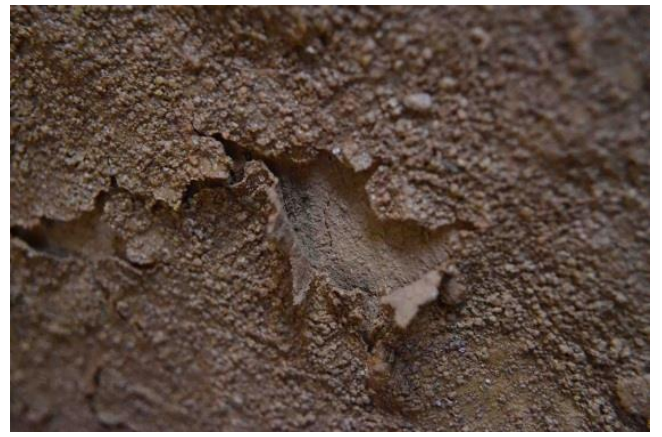

Figura 95 - Resultado da aplicação após algumas semanas

Devido à viscosidade da goma de polvilho, a aplicação manual parece a mais eficiente, principalmente, se aplicada pura. A viscosidade é grande e aumenta com o tempo.

A fragmentação da goma, que ocorreu algumas semanas depois (Figura 96) e provocou questionamentos: por que a mistura enfraqueceu e partiu-se ? Foi ponderado que poderia ter sido pela umidade e/ou pela ausência de ancoragem

O processo de produção da goma inclui o aquecimento da mistura água e polvilho em pó para que a combinação química dos dois ocorra. Provavelmente se a mistura for manuseada ainda quente a penetração no barro seja melhor e a 
fragmentação não ocorra. Mas vale ressaltar que se a goma fosse manipulada em temperatura mais elevada, provavelmente o uso das mãos não seria possível, mesmo com luvas.

A aderência com o bambu ficou também comprometida e as mantas deslocaram-se em alguns pontos. Utilizando ferramentas de tapeçaria como agulha e linha de algodão cru foi experimentado costurar as mantas à estrutura. A técnica remeteu à tapeçaria ou à costura em veleiros, mas o resultado do experimento não foi satisfatório. Grande parte do procedimento só diminuiu o tamanho dos bolsões de deslocamento. As mantas de barro foram recolhidas para serem utilizadas em outros experimentos e uma nova técnica foi experimentada.

\subsubsection{Compósitos de fibras e barro sobre o parabolóide}

A avalição dos bolsões de deslocamento é que havia pouca ancoragem entre as duas mantas de tecido-barro e com a estrutura de bambu. Após alguns testes no local, a aplicação de compósitos de barro com fibras foi a alternativa experimentada.

Utilizando esta técnica foi possível perceber uma maior facilidade em criar a conexão entre as camadas de fibrobarro, em aprisionamento mecânico. Havia consciência do aumento significativo do peso sobre a estrutura, mas esse aumento de peso não era considerado grande o suficientemente a ponto de inviabilizar o experimento.

Para aplicar a nova camada de cobertura, como a PUC-Rio recebeu o Encontro Nacional dos Estudantes de Design ( $\mathrm{N}$ Design), foi oferecido aos participantes do congresso uma oficina do uso de fibrobarro. O método empregado para aplicar foi o desenvolvido ao longo do processo de construção com as esferas e do pesquisa de campo aplicada na Horta do Anil.

Alunos de design, cuja grande maioria nunca havia trabalhado com qualquer técnica de construção com barro cru, apropriaram-se facilmente das técnicas do fibrobarro. Após uma demonstração, o grupo se dividiu em duplas que trabalharam frente a frente no processo de preparo do compósito (Figura 97). 


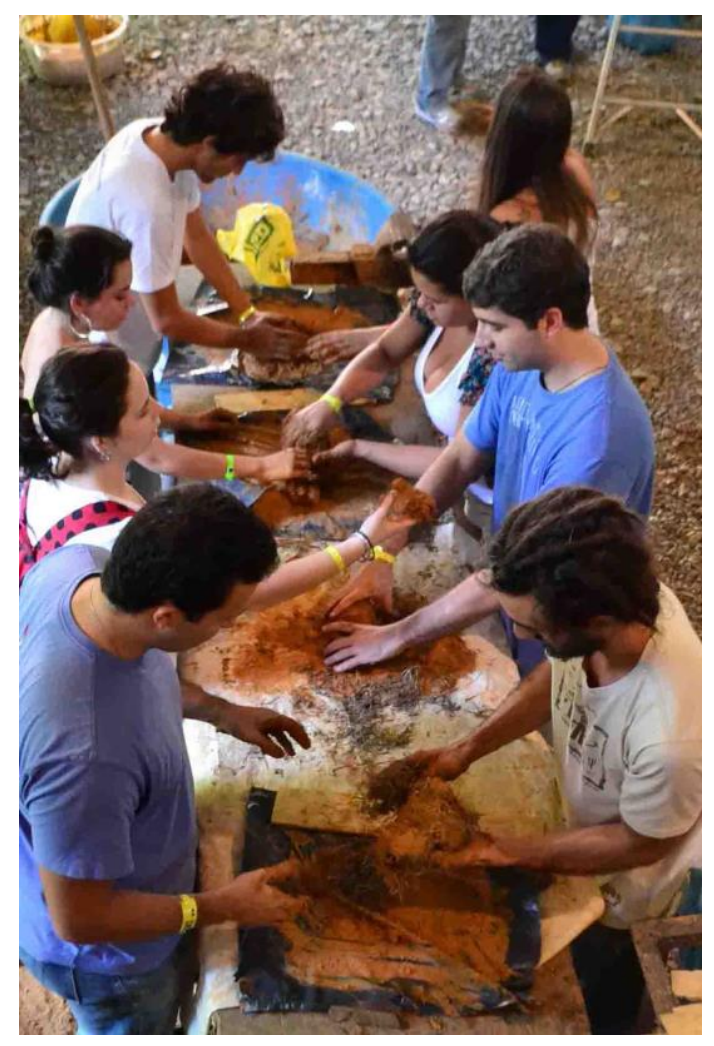

Figura 97 - Preparo coletivo das placas de fibrobarro

Foi possível perceber alguns sinais de como a interação variava entre os estudantes. Alguns alunos que pareciam mais envolvidos utilizavam os dedos para melhorar a mistura e promover o preparo do compósito enquanto outros, provavelmente, com receio de se sujarem muito ou se machucarem nas fibras, ou mesmo pela absoluta falta de intimidade com o processo gestual, usavam as regiões mais duras da palma da mão para misturar as fibras de grama e o barro peneirado (Figuras 98 e 99).

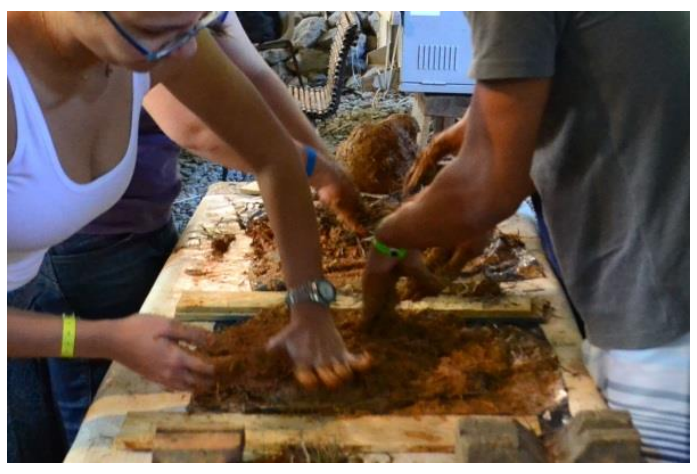

Figura 99 - Aluna usando a palma da mão para misturar as fibras

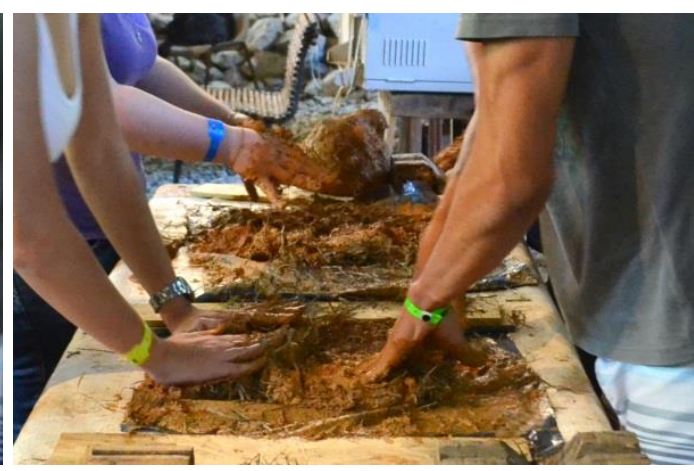

Figura 98 - Exemplos gestuais de interação com o compósito

Para facilitar a padronização e aplicação das camadas, foram fornecidos para cada dupla, batentes de madeira para homogeneizar as placas (Figura100). Também foi fornecida uma lona de plástico de aproximadamente 1 metro 
quadrado, que os participantes usavam como suporte para o preparo do compósito. Esta lona facilitava depois o transporte e aplicação do compósito até a estrutura (Figura 101).

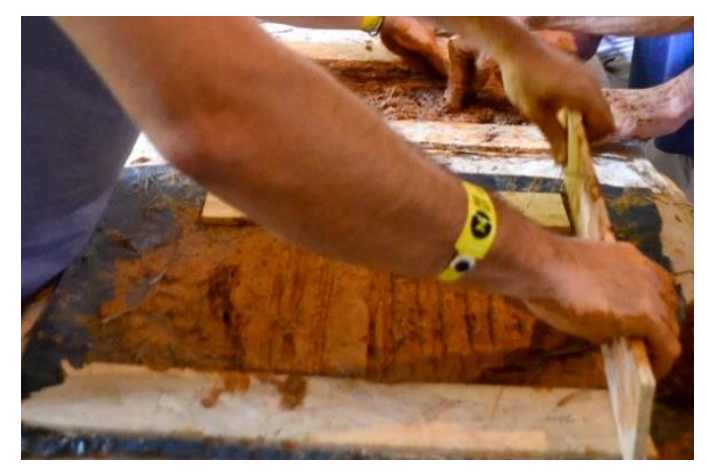

Figura 100 - Estudante usando batentes de madeira para homogeneizar a espessura do compósito.

Um desafio que encontrado foi convencer os estudantes de que a quantidade de fibras utilizadas ainda era pequena. Em mais de uma ocasião houve a necessidade de pedir que acrescentassem mais fibras. Conceitos como colocar fibras até "ver que o barro não aguenta mais" ou proporções visuais como 3 partes de fibra para uma de barro, nem sempre foram seguidas.

Provavelmente isso aconteceu porque a facilidade de manuseio diminua com o aumento da quantidade de fibras adicionadas. Assim, o participante não colocava tanta fibra para justamente não dificultar o trabalho. Uma solução que encontramos foi lembrar aos alunos de fazerem o teste mostrado na Figura 27 (página 59). Mesmo assim alguns dias após o experimento era perceptível a um olhar mais atento que a quantidade de fibras utilizada em cada placa era bem diferente. Algumas placas apresentaram fissuras e trincas típicas de compósitos sem a devida quantidade de fibras.

Outro desafio foi lembrá-los a pressionar o compósito para melhor fixação à estrutura (Figura102). Muitos participantes ficavam mais preocupados em alisar para dar um acabamento estético, do que com o funcionamento, provavelmente isto ocorreu pela tradição da cerâmica, o referencial mais próximo para muitos ali presentes. 


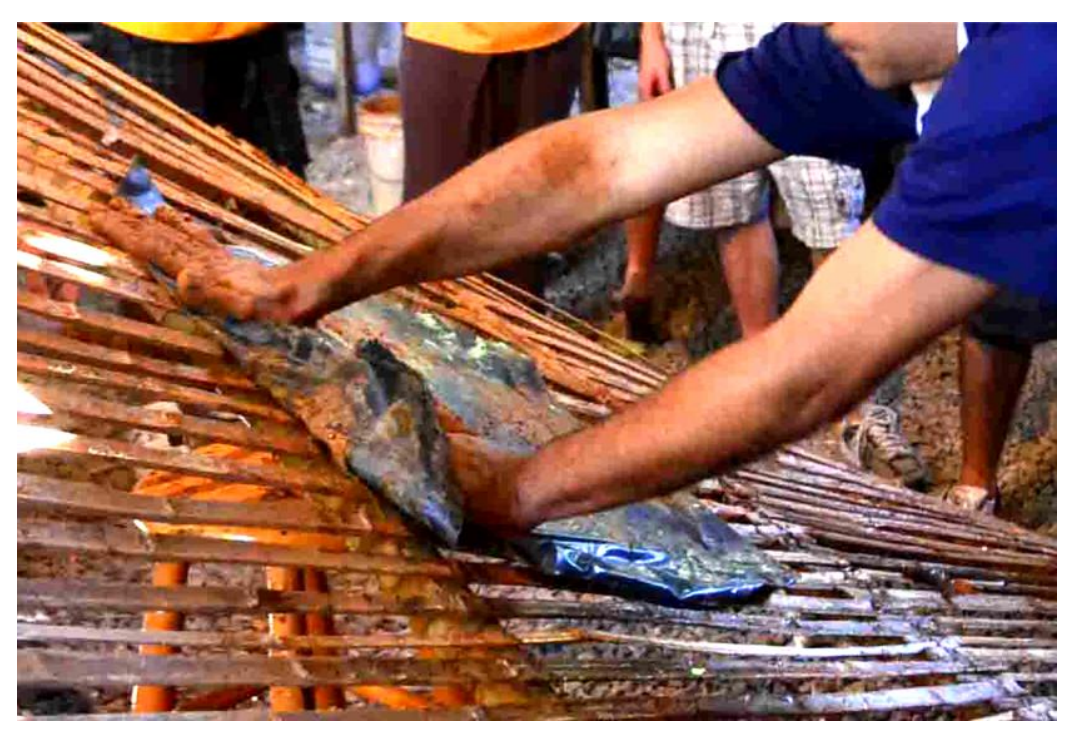

Figura 102 - Pressionando a placa para melhorar sua fixação na estrutura

A oficina durou cerca de 2 horas com um público bem oscilante. Neste período foi produzida camada de fibrobarro suficiente para cobrir quase toda face da estrutura, faltando apenas as bordas. Contudo, algumas semanas depois, descobrimos que o experimento estava comprometido.

Ao movermos a estrutura foi perceptível que a estrutura de bambus estava cedendo com o peso maior do que era esperado. Com o tempo constatamos que alguns bambus estavam contaminados pela espécie Chlorophorus annularis (PaDIL 2005), conhecido como Tigre. Ao desmontarmos a estrutura foi possível recolher as placas que apesar de rígidas estavam quase intactas. Em breve as mantas seriam utilizadas para cobrir outras estruturas.

\subsection{Horta Orgânica do Jardim Anil}

Talvez este devesse ser o último trabalho a ser apresentado. Afinal essa investigação foi a mais longa e apontou vários pontos importantes da proposta inicial.

A Horta Jardim Anil faz parte de um projeto da Prefeitura da cidade do Rio que implantou algumas hortas orgânicas pela cidade para estimular o cultivo orgânico de hortaliças. No bairro do Anil o projeto era administrado pela Sra. Dirce Teixeira que, junto com bolsistas e voluntários, realizava a manutenção do espaço.

Quando esta pesquisa iniciou-se, o projeto no Anil já estava estabelecido com alguns vínculos e encontros regulares. Foi estabelecido que o LILD, em parceria com os frequentadores da Horta, iriam construir um minhocário. Após 
análise dos materiais e das possibilidaes técnicas do local e da equipe, iniciamos a construção de uma treliça que depois de receberia uma camada de barro. Para mais informações sobre o processo de desenvolvimento da forma e da metodologia de trabalho aplicada é aconselhável Yamaki (2012), um dos pesquisadores que iniciaram apesquisa no local.

Após o desenvolvimento da treliça base, que foi feita com cordas de nylon de $3 \mathrm{~mm}$ e bambus da espécie Phyllostachys aurea, também conhecido em algumas regiões como bambu-mirim, foi ajustada no local que designamos que ela ficaria. Esta treliça depois de montada foi colocada sobre algumas pedras presentes no local para que evitar o contato direto com a umidade do solo. Para preservar a estrutura da chuva colocamos uma lona tencionada sobre a estrutura (Figuras 103 a 105).

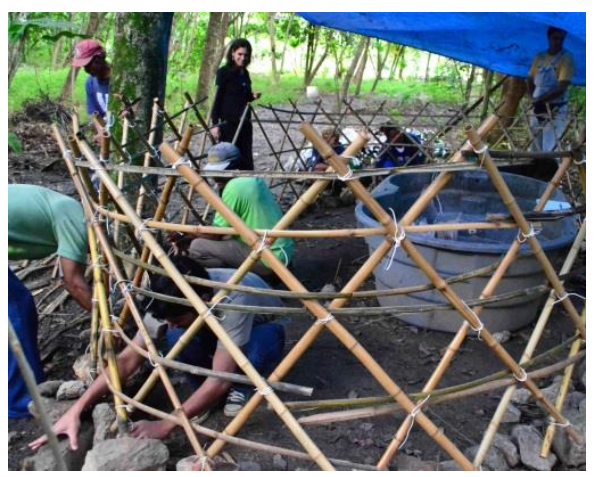

Figura 103 - Treliça montada com lona sendo reforçada na base
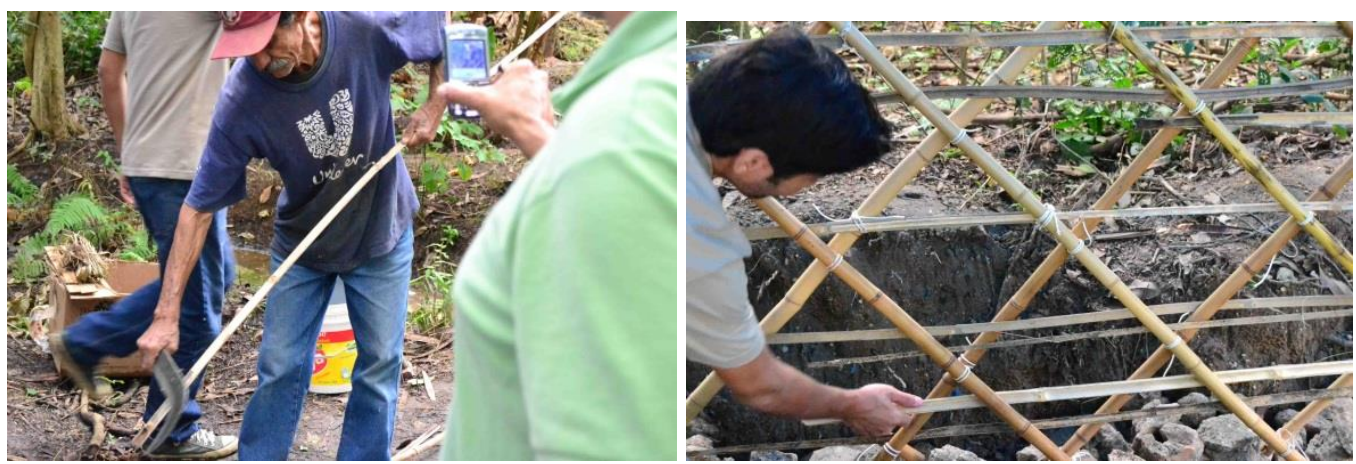
Figura 105 - Ripas de bambu sendo aparada

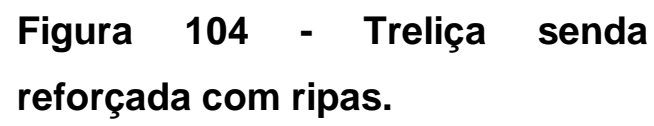

Finalizada esta preparação o trabalho aconteceu em duas frentes: um grupo começou a dividir bambus em ripas e outro começou a produzir placas de fibrobarro para aplicar sobre a estrutura. As ripas de bambu possuíam mais de uma função. Elas serviram para reforçar longitudinalmente a estrutura ajudando a distribuir as tensões, ajudavam a estrutura a manter a forma definida, serviam 
para diminuir o espaçamento entre os bambus e atuavam como suporte para colocarmos as placas de fibrobarro. Especialmente estes dois últimos itens eram essenciais para o trabalho a ser realizado pelo segundo grupo.

Um fato curioso que aconteceu neste processo foi que a maioria dos homens que trabalhavam na horta preferiu trabalhar na função de produzir ripas enquanto as mulheres optaram por preparar e aplicar as placas de fibrobarro (Figura 107 e Figura 107 ). Mesmo após a produção das ripas ter terminado esta divisão continuou a acontecer. Os homens preferiram colaborar no processo de coleta e produção da argila, trabalhos mais brutos, do que aplicar as camadas de fibrobarro. Conversando com as voluntárias, foi esclarecido que os homens achavam que as técnicas com bambus eram mais úteis para eles do que o fibrobarro.

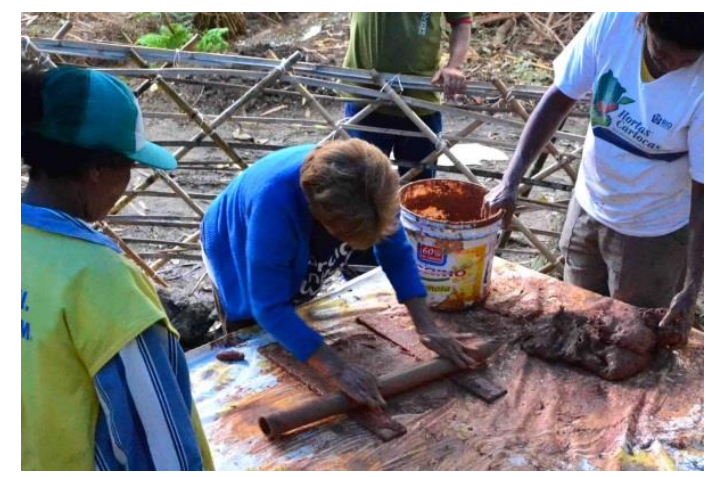

Figura 107 - Funcionárias da Horta preparando os compósitos

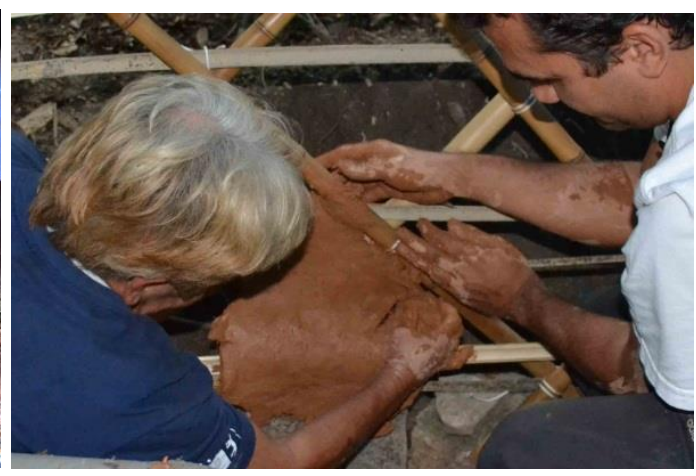

Figura 106 - Aplicação da placa na estrutura

Vale ressaltar que a maioria dos moradores da região é constituída de pessoas da chamada classe $\mathrm{C}$ e $\mathrm{D}$, de relativamente baixo poder aquisitivo. Mais especificamente o grupo que trabalha na horta é de pessoas com mais de quarenta anos que vieram do nordeste brasileiro e com grau de escolaridade baixo. A maioria dos trabalhadores não terminou o segundo grau. Talvez, estes senhores tenham a visão que comentada nos primeiros capítulos, quando foram abordados os desafios da construção com terra crua de ter uma barreira cultural por estar associada à construção para miseráveis e sem status social.

Independentemente desses preconceitos estarem presentes ou não, e da baixa adesão da ala masculina, o trabalho desenvolvido pelo grupo gerou muitos frutos. Apesar da maioria nunca ter construído com barro cru, por serem migrantes do nordeste ainda novos, muitos possuíam a memória afetiva de verem os avós e os pais construírem casas de pau-a-pique na infância. $O$ trabalho em grupo, normalmente em duplas, gerou inúmeras conversas sobre 
saberes antigos de construção, com recursos daquela época. Ao mesmo tempo, a metodologia do LILD de trabalhar com muitas fibras e com superfícies mínimas garantiu àqueles que participavam dos encontros, a sensação de novidade e de estarem diante de algo novo.

A cada etapa o trabalho da semana anterior era visto e avaliado para sabermos se o caminho que estávamos seguindo era o mais apropriado. Desta forma também podíamos mostrar aos usuários da Horta, a viabilidade da técnica. Vale ressaltar que aplicamos as placas em um dos lados da estrutura. Do outro lado fazíamos uma pequena placa do tamanho da palma da nossa mão, que apelidamos de "pizza" (Figura 108 e Figura 109), para cobrir os bambus expostos do outro lado. Este foi um método para buscarmos uma superfície com o mínimo de material possível na parede do "minhocário"4.

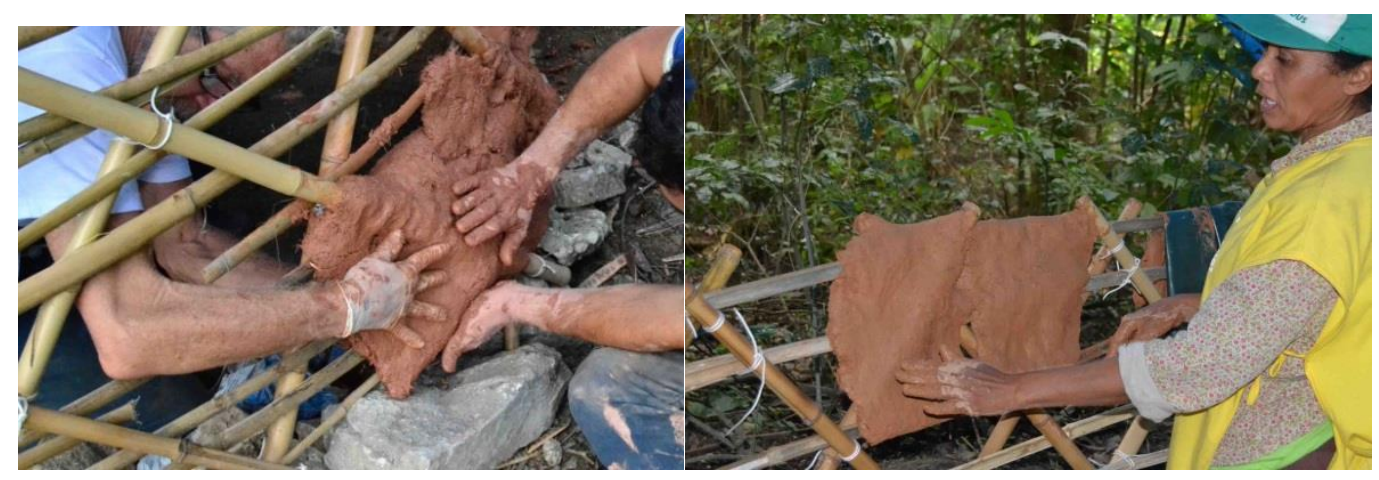

Figura 109 - Pressionando a placa dos dois lados para fixar e vedar o bambu.
Figura 108 - Avaliação semanal do que foi feito na semana anterior.

Entre a troca de saberes gerado surgiu a possibilidade de trabalho com as fibras de bananeira. Foi ensinado, a fazer cordas (Figura 110) e que em alguns locais do nordeste se fazem telhas com as fibras de bananeira. Esta "convivencialidade" (Illich 1976), este intercâmbio de conhecimentos ajudou a criar vínculos afetivos e foi fonte de muitas descobertas.

\footnotetext{
${ }^{4}$ Não encontramos a palavra minhocário no dicionário, a mais próxima foi minhocultura, porém preferimos deixar a palavra como foi dita por todos nós.
} 


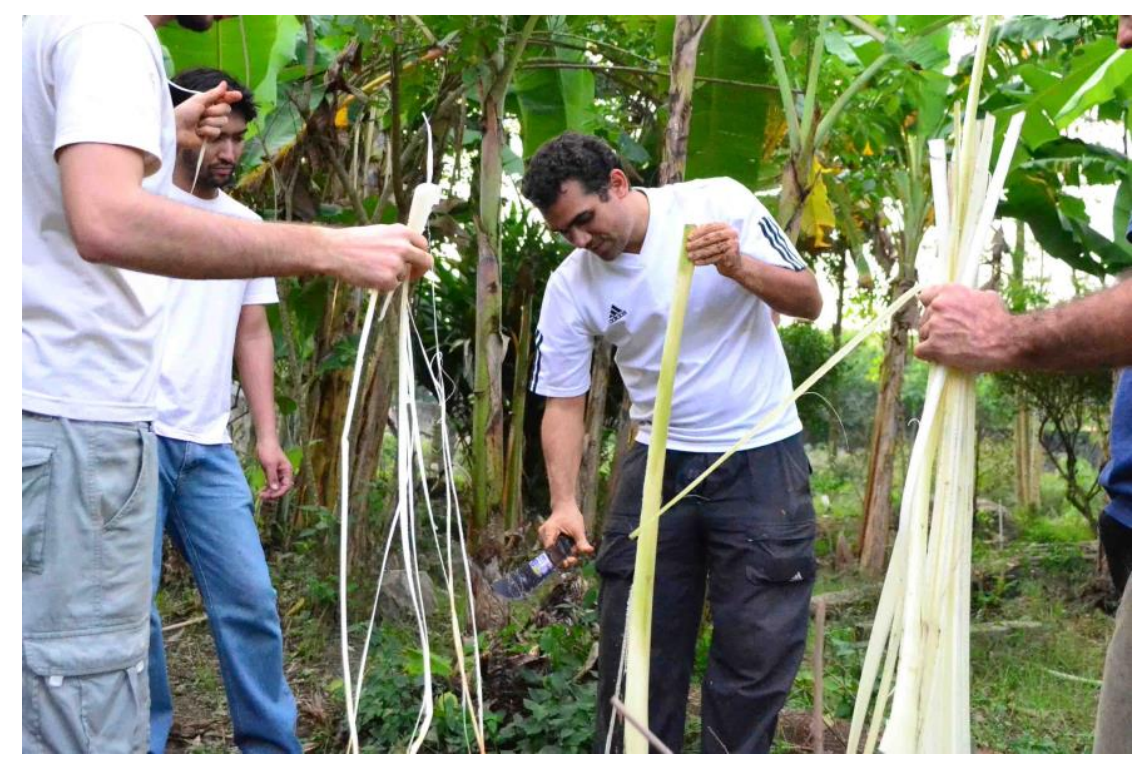

Figura 110 - Pesquisadores da PUC aprendendo a produzir embira de banana

É importante ressaltar que não continuamos os experimentos com as fibras de bananeira pela pouca disponibilidade local. Além disso, durante o processo de pesquisa, veio a notícia de que a fibra de bananeira, ao secar completamente, perde parte da sua força de tração. A importância de associar fibras de diferentes tamanhos e origens para que o compósito fique mais resistente ficou ainda mais evidente. A experimentação em diferentes contextos nem sempre possibilitou a associação de mais uma fibra, mas sempre que possível, a mescla de tamanhos e espécies foi favorecida.

Foi a partir da realidade local de pouca disponibilidade de fibras no local, é que os compósitos grama-barro foram feitos. Essa grama, na realidade era usada como cobertura vegetal dos canteiros, para não receberem ação direta da chuva e do sol.

Como as fibras utilizadas tinham outra importante função, e ainda mais, não existiam em grande quantidade, foi resolvido pesquisar sobre a quantidade de fibras para fabricação do compósito. Além da fibra de bananeira foi experimentada também a Colônia (item 4.2 na página 56). A pesquisa de fibras durou quase toda a vivência no local até, no meio de 2012, a doação de uma grande quantidade de fibras de piaçava.

Apesar da pesquisa prática, no LILD, sobre a resistência das fibras de piaçava para se aglutinarem ao barro, a solução que encontrada já estava presente no repertório técnico do Laboratório (Figura 111). Além de usar mais água na mistura para amolecer mais as fibras, foi a metodologia de aplicação que foi desenvolvida na construção do Túnel Expositor (Item 5.3.1, página 107). 


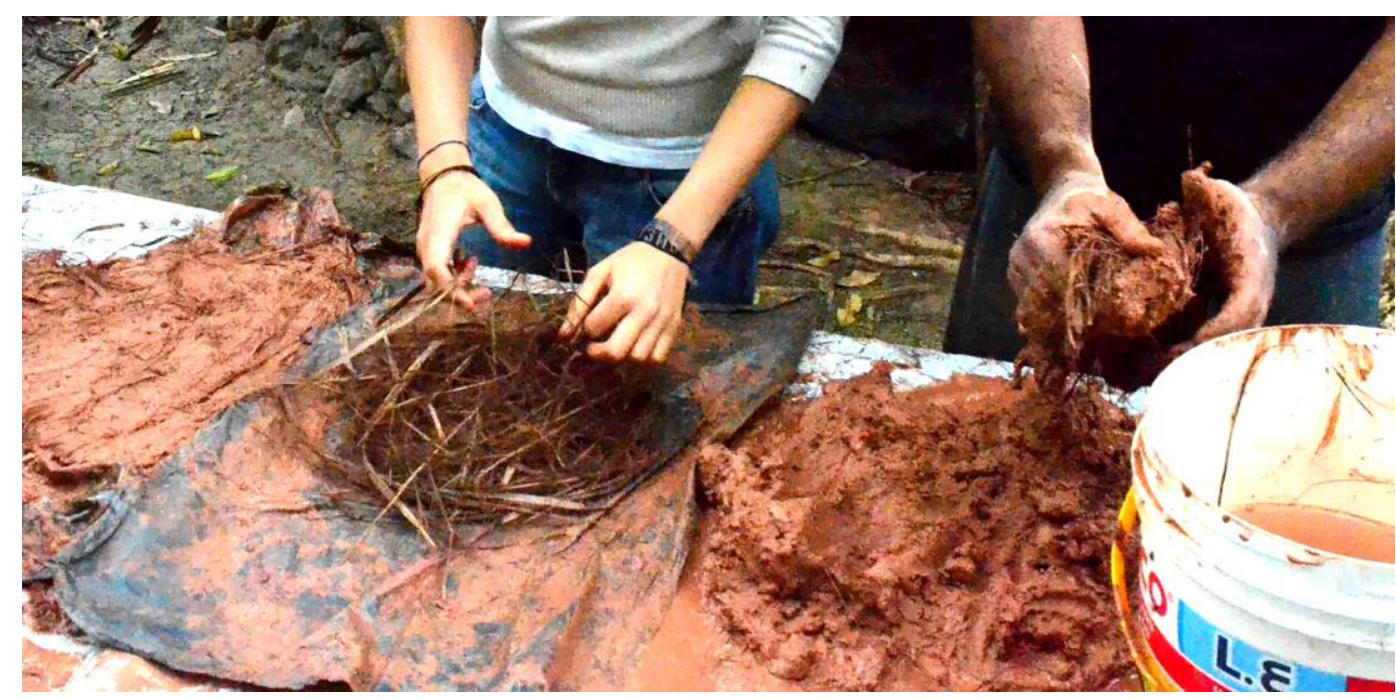

Figura 111 - Voluntários construindo mantas com barro e fibras de piaçava

Foi através da vivência local a importância do uso de uma folha de plástico como interface para aplicação da placa moldável de barro (Figura 113) foi percebida. Com esta nova ferramenta o controle sobre a aplicação cresceu muito e a qualidade estética da placa aplicada aumentou sensivelmente, além de ter se tornar uma garantia maior da homogeneidade da estrutura.

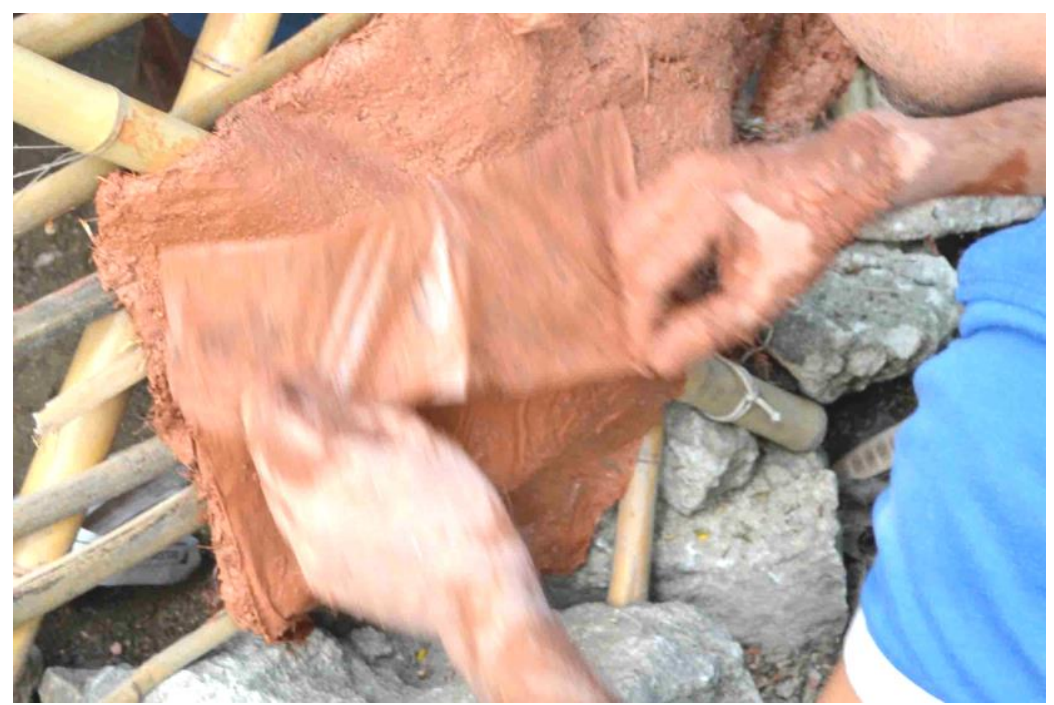

Figura 112 - Técnica de retirada do plastic suporte

A vivência no Anil teve altos e baixos durante o processo de construção. Após 5 meses de vivências, a rotina semanal de aplicar placas de barro sobre a estrutura diminuiu o número de interessados até que a disponibilidade de fibras cessou. Além disso, a própria equipe do LILD ficou dividida em outros projetos como o Túnel de fibrobarro e pesquisadores que precisaram concentrar seus esforços em escrever sobre suas pesquisas. 
Isso levou ao trabalho ficar interrompido por quase um ano. Neste período a cobertura de fibrobarro ficou protegida por pedras que a elevavam $30 \mathrm{~cm}$ do chão e pela lona de polipropileno, que impedia a maior parte da chuva incidir diretamente sobre a estrutura. As regiões que eram protegidas pela lona tiveram pouquíssima alteração de seu estado antes e depois da construção. As únicas partes que não ficaram protegidas receberam chuvas indiretamente, mas ficou evidente a capacidade erosiva da água (Figura 113).
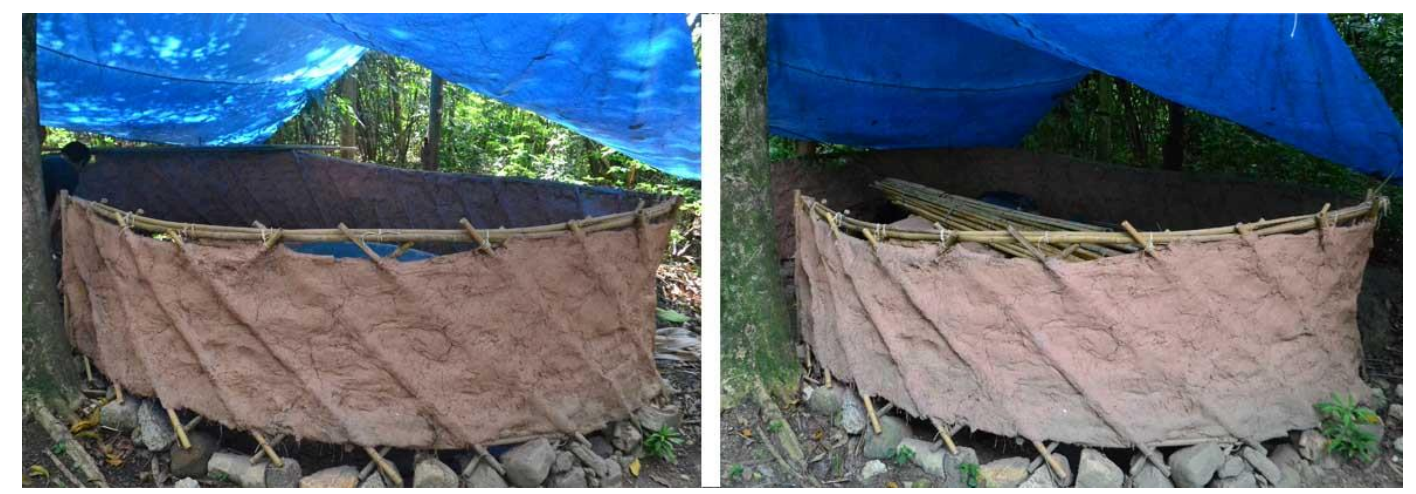

Figura 113 - Minhocário em Agosto de 2011 e em Fevereiro de 2012

A cobertura apropriada para evitar as chuvas (diretas e indiretas), um bom isolamento da umidade vinda do chão e a estrutura poderia ter ficado intacta. Ou como se diz na roça "um bom chapéu e uma boa bota" (Easton, 2005 e Guelberth \& Chiras, 2009). Também tivemos um ponto no qual a lona furou gotejando diretamente na parede de barro (figura 114). $O$ estrago foi maior e o caminho das gotas ficou evidente. Contudo este local foi restaurado com barro úmido pressionado com as mãos no local. 


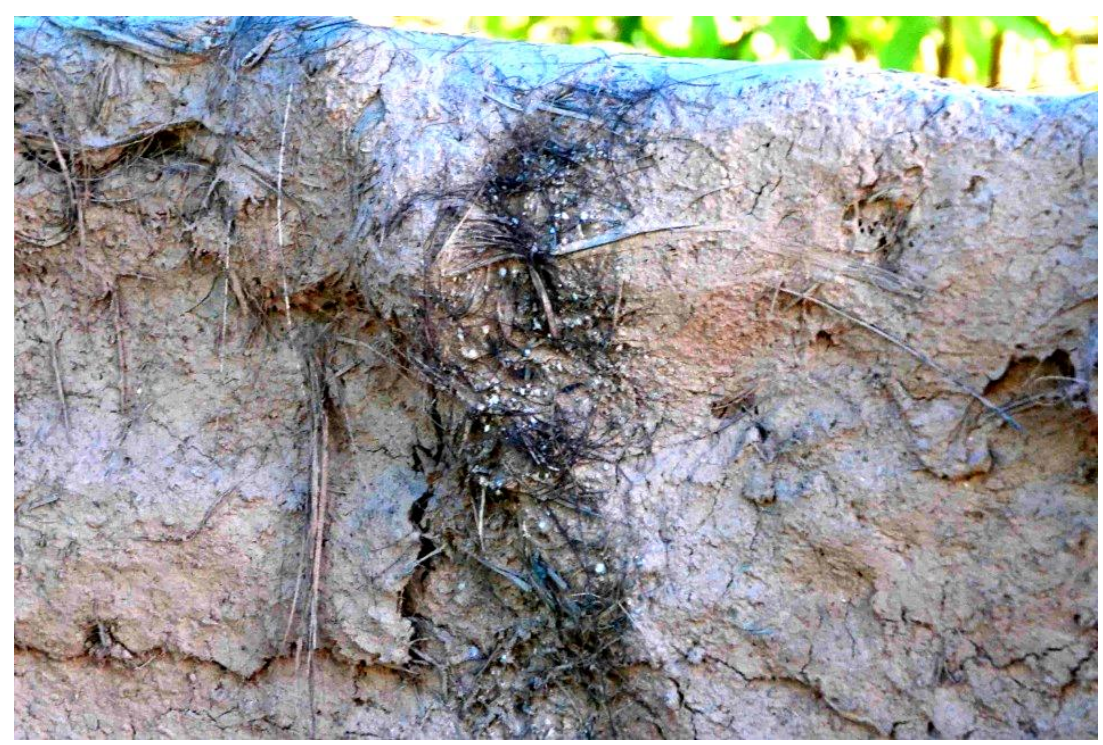

Figura 114 - Erosão no fibrobarro feita por uma goteira. Fibras ficam aparentes.

Nesta retomada da construção, a presença abundante de barro obtido em um campo de futebol ao lado da horta e a grande quantidade de fibras disponíveis, acelerou bastante o processo de confecção da camada de cobertura da estrutura. Além da disponibilidade maior dos recursos materiais outro fator ajudou na aceleração da construção da estrutura: o constante exercício de fabricação de compósitos, que excitados ao longo do processo de fabricação das estruturas, que compensou relativamente a sensível diminuição da equipe de trabalho. Isto ocorreu porque a Equipe da Horta também diminuiu sensivelmente e todos os funcionários disponíveis não podiam mais deixar de trabalhar na horta para realizar trabalhos paralelos.

Após a produção de inúmeros modelos para a cobertura (Yamaki 2012) (Figura 115) a cobertura escolhida foi uma estrutura de dois icosaedros conjugados que receberam uma lona de polipropileno. Para evitar o atrito entre os bambus tuldoides (bambusa tuldoides) utilizamos pedaços de feltros amarrados. Para auxiliar na durabilidade dos bambus, usamos pedras encontradas no local para elevar a estrutura do solo (Figura 116). 


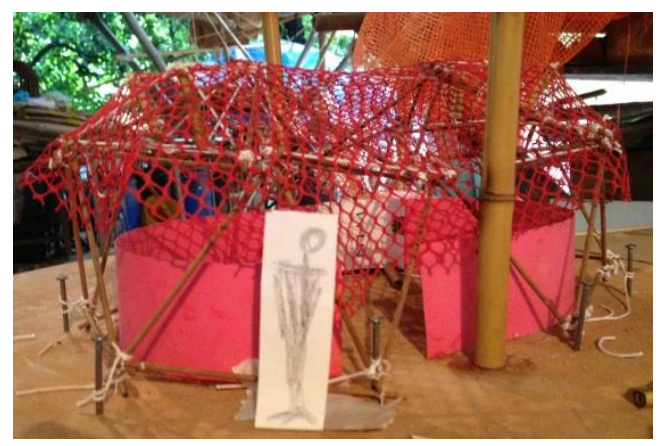

Figura 115 - Miniatura da construção de dois icosaedros conjugados

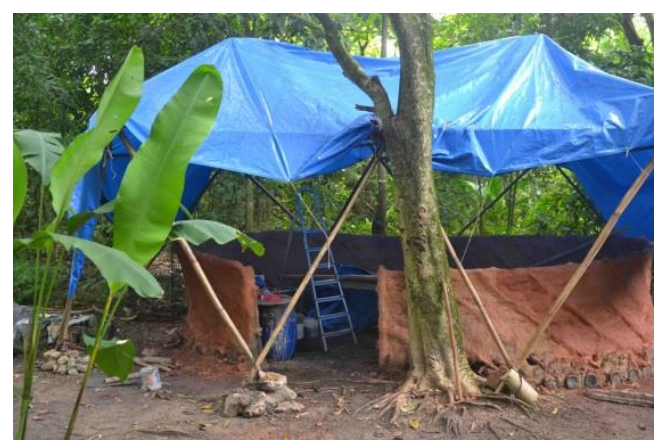

Figura 116 - Estado da arte da construção em 1/03/2013

A parte final do trabalho foi realizada somente por pesquisadores e voluntários do LILD. O ritmo voltou a ser semanal e foi possível observar, mais uma vez, o valor do cuidado (Boff 1999) a cada etapa do processo. Em alguns momentos, por pressa ou afobação para terminar logo uma etapa e começar a seguinte, alguns detalhes não eram devidamente realizados. A solução que encontrada foi, a cada novo dia de trabalho, avaliar o que foi feito na semana anterior, consertar possíveis erros, e somente depois disto é que a etapa seguinte foi iniciada. Este processo, apesar de mais lento, diminuiu os enganos e aumentou a confiança da equipe de que a prioridade era a qualidade da ação (Schumacher 1973).

Outro grande aprendizado levantado no laboratório de campo foi a oportunidade de reutilizar o fibrobarro já usado em outra vivência (Item 5.3.3, p. 115). Com a necessidade de finalizar a estrutura e a falta de mão-de-obra, foi utilizado fibrobarro armazenado em rolos, para cobrir partes da estrutura de bambu. Apesar de estar armazenado sem muito cuidado há mais de 14 meses o comportamento do material nos surpreendeu.

Devido às características da armazenagem, foi possível encontrar vários tipos de fibrobarro em um mesmo rolo. Algumas partes do barro se transformaram em pó e desprenderam-se completamente das fibras. Outras partes haviam endurecido, ainda com fibras, em vários fragmentos de aproximadamente $20 \times 20 \mathrm{~cm}$. Identificamos ainda uma terceira categoria em que as fibras tinham comportamento parecido com papel molhado, tão fácil era a segmentação do compósito.

Com exceção deste último, todos os outros foram utilizados para tapar as falhas na estrutura. O fibrobarro foi hidratado com um pouco de água, reforçado com mais barro local (figura 117), que estava sendo umedecido há semanas. 
Depois o fibrobarro foi aplicado na estrutura seguindo os procedimentos usuais de hidratar e promover a fixação por pressionamento.

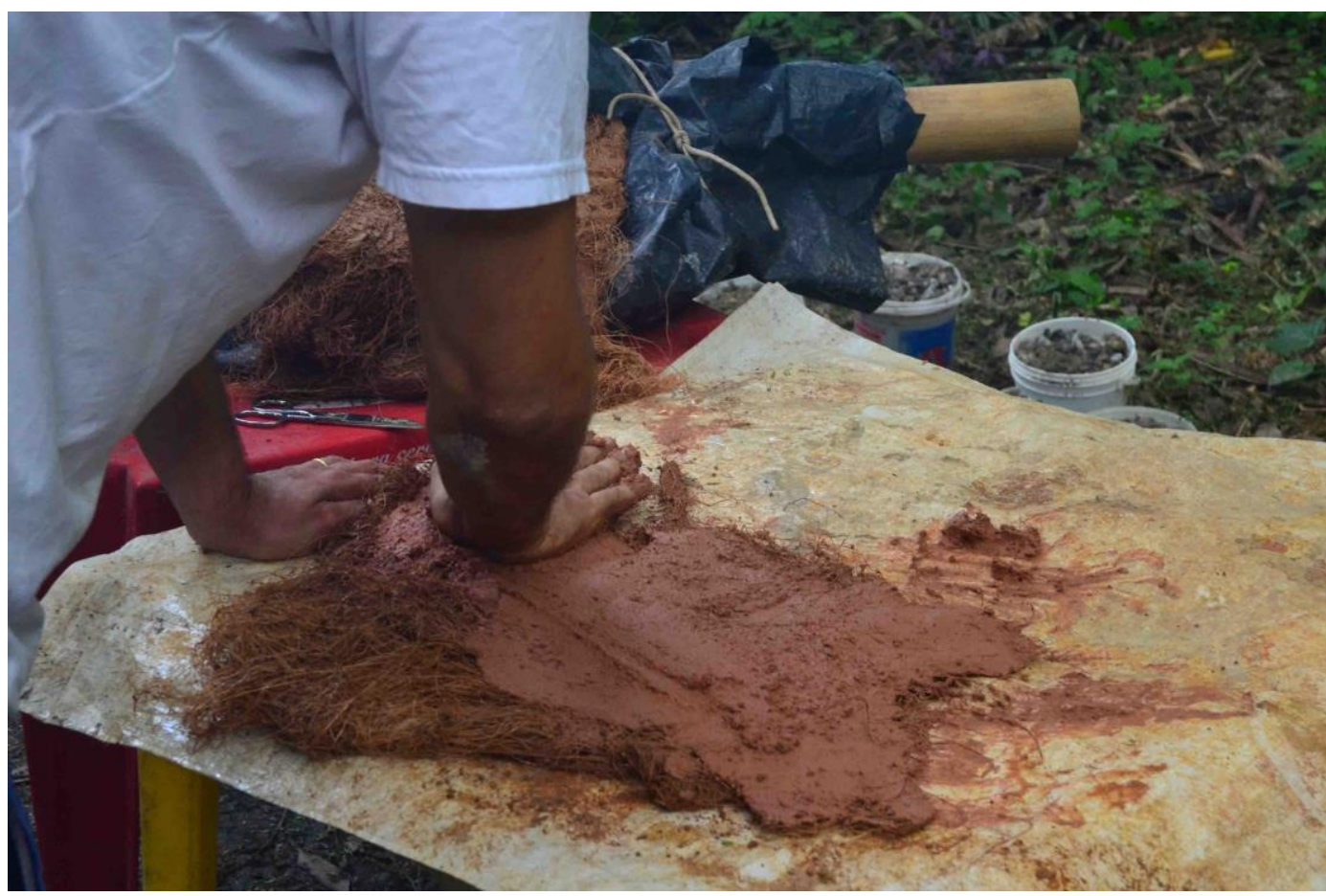

Figura 117 - Nova aplicação de barro em uma placa de fibrobarro seca que perdeu um pouco da argila

Reutilizar o fibrobarro do Túnel Expositor (página 107) mostrou mais uma possibilidade do uso do fibrobarro. Uma semana após a aplicação já não era mais possível identificar o que era fibrobarro novo ou reutilizado. Mesmo que as fibras usadas tenham sido bem distintas.

As paredes de barro, feitas ao longo de meses de experimentação e aprendizado, apresentavam uma grande heterogeneidade na sua superfície. Nem tanto pela coloração do barro aplicado mas pelos diferentes grupos que participaram das aplicações do fibrobarro. Alguns tiveram a preocupação de alisar as paredes para homogeneizá-las, outros contavam que haveria mais uma camada de cobertura e a deixavam com marcas de dedos, frutos da ação de aplicação do fibrobarro na estrutura. Além da própria ação do tempo que provocou algumas fissuras.

Por meio de uma pesquisa experimental no próprio local foi um método para tornar a superfície mais igual antes da aplicação da cobertura final. Inicialmente hidratamos a superfície com um borrifador e, usando as mãos, tentamos aplicar uma fina camada de barro diluído (razão de 2:1 de barro:água). O resultado foi desastroso. 
Como o barro não estava peneirado, a tarefa, além de cansativa, machucava as mãos. O resultado estético também deixou a desejar já que a camada aplicada não era suficientemente fina e, em diversos pontos, o barro aplicado começou a apresentar pequenas fissuras.

A solução encontrada foi lixar a superfície com um pedaço do feltro usado para proteger a lona de cobertura do bambu (Figura 118). Desta forma eliminamos muitas protuberâncias na superfície. Para homogeneizar a eu a técnica mais eficiente era diluir ainda mais o barro (razão 3:1) e aplicar a "aguada" com uma trincha ou pincel de cerdas longas. Essa técnica, mesmo antes da aplicação do pastacal, fez com que as paredes de fibrobarro ficassm com um aspecto extremamente interessante pela unidade gerada (Figura.119)

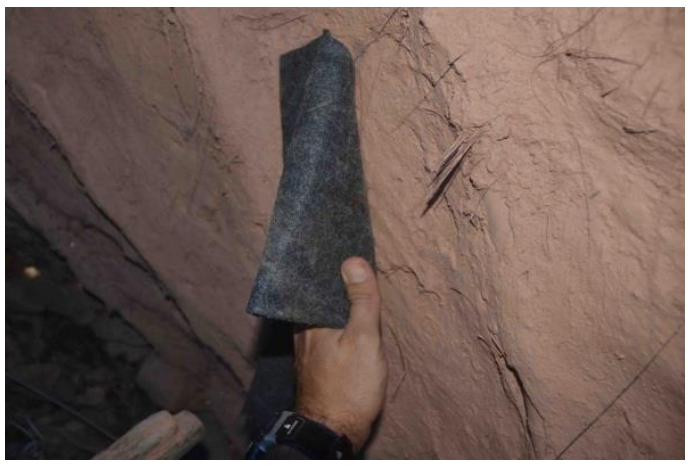

Figura 119 - lixando a superfície usando um retalho do feltro usado na cobertura

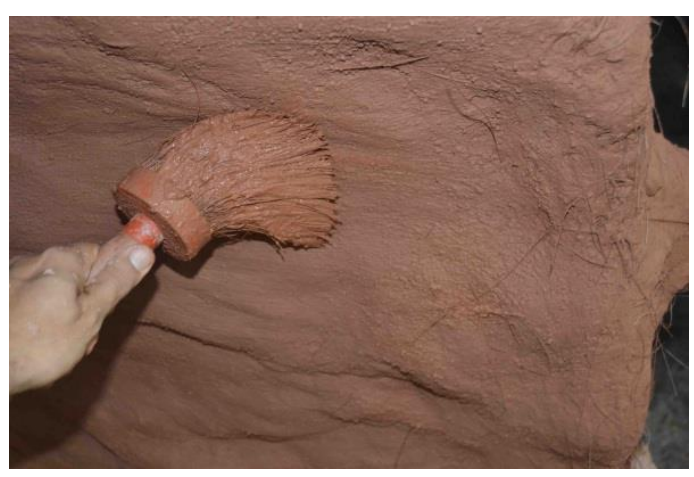

Figura 118 - aplicando a aguada de barro para homogeneizar a superfície

O resultado surpreendeu pela plasticidade e facilidade do processo. A camada de proteção ficou fina mas as fissuras no compósito não aconteceram. Em todo caso era possível aplicar mais camadas finas que só irima aumentar a estabilidade à intempéries (Figuras 120 e 121).

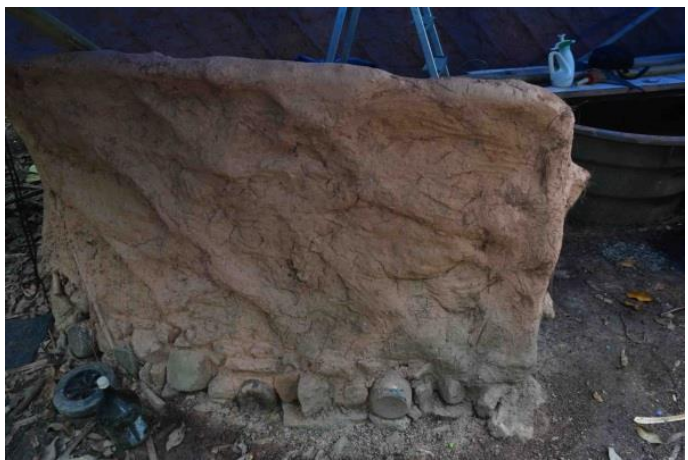

Figura 120 - Parede de fibrobarro em estado bruto

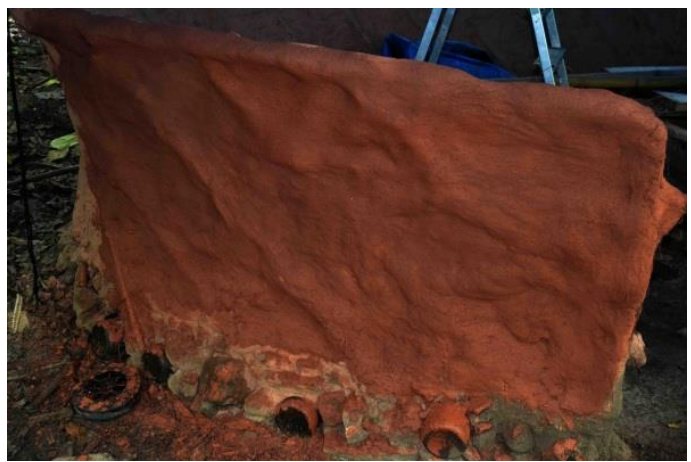

Figura 121 - Fibrobarro depois da aplicação da camada fina. 
Não foi possível ver o objeto em uso efetivo, mas quando a estrutura estava começando a ter seu desenho definido, Dona Dirce consultou-se para saber se era "obrigada" a usar a estrutura como minhocário. Perguntou se poderia usar o espaço como uma sala de aula e outras possibilidades de uso da estrutura. Foi realçado que o objeto poderia ter várias funções.

Esta observação iniciou questionamentos sobre a real apropriação da equipe local do espaço. Dona Dirce nunca participou ativamente das atividades, e talvez aí seja um erro cometido, mas os períodos de inatividade e a drástica diminuição da equipe local no desenvolvimento da atividade provavelmente os distanciaram da consciência de que eles eram os verdadeiros donos do espaço. É claro que o fato da Dona Dirce espontaneamente imaginar possibilidades de uso para a construção foi um sinal de uma vontade de utilizar o objeto de estudos, mas mesmo assim, a dúvida de que poderia ter sido feito para não afastar objeto-usuário persistiu .

O trabalho na Horta do Jardim Anil apesar dos seus altos e baixos foi fonte de inúmeras descobertas. A cada visita algo foi aprendido sobre os gestos, a metodologia, e as vantagens e desvantagens de se fazer trabalho com voluntários. A constante sedução e agilidade na construção são necessários, mas nem sempre são possíveis em uma pesquisa acadêmica.

\subsection{Túnel expositor}

Neste item é relatado de uma construção que contribuiu para o enriquecimento do gestual de trabalho da pesquisa. No segundo semestre de 2012 o LILD foi convidado para a I Mostra de estruturas de bambu: Materiais não-convencionais e tecnologias sustentáveis.

Como objeto de exposição os pesquisadores do LILD projetaram e construíram um túnel que inicialmente seria feito exclusivamente de fibrobarro sem a utilização de qualquer outro elemento estrutural (Figuras 122 e 123). A forma escolhida foi de uma curva catenária de 2,1 $\mathrm{m}$ de altura e 1,5 m de largura. Cada um dos 3 módulos do túnel ficou com $2 \mathrm{~m}$ de comprimento (Ripper, Lazaroni, \& Souza, 2012). 


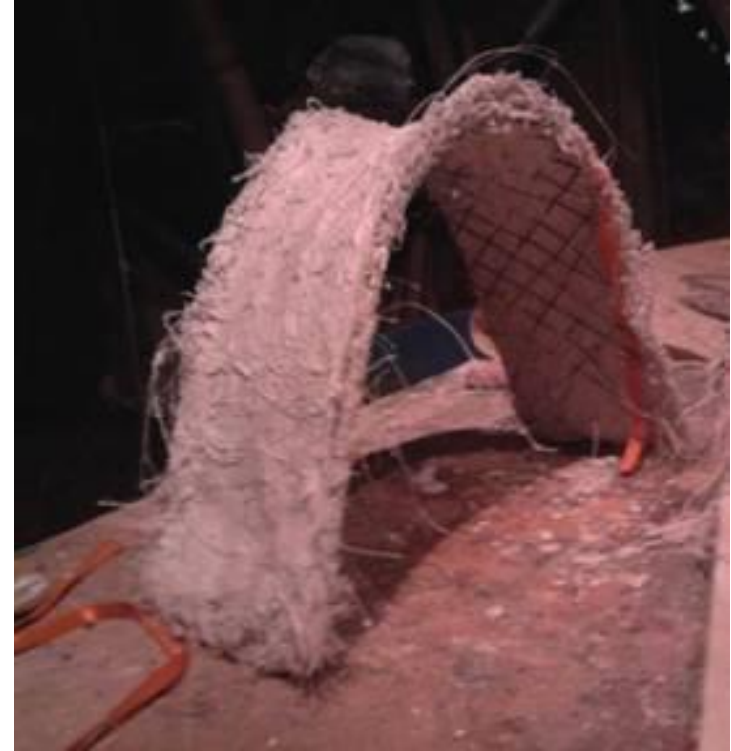

Figura 122 - Primeira minitura do Túnel Expositor

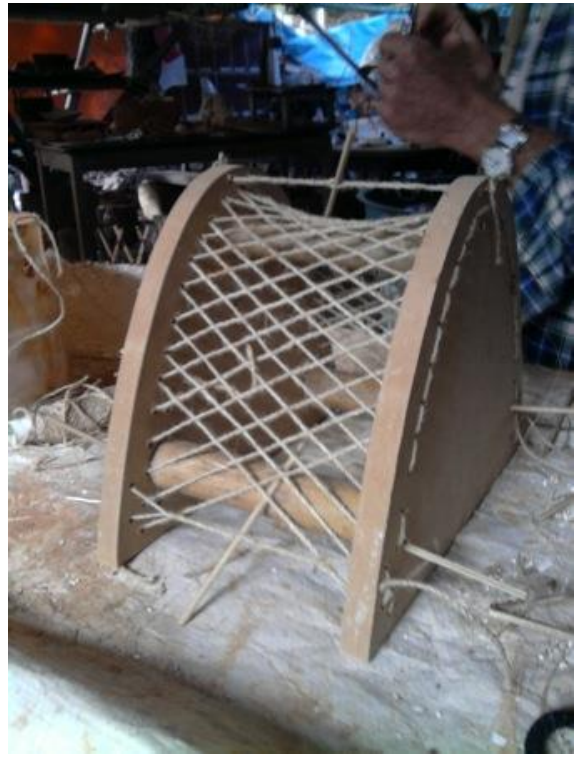

Figura 123 - Minitura do molde de fibrobarro

Após a resolução da estrutura, o molde que foi feito de corda de sisal, vergalhões de ferro e tubos de ferro, foi o momento da aplicação do fibrobarro. Como a intenção era de que a estrutura fosse auto-portante depois de seca a estrutura foi construída com a fibra de melhor resistência à tração disponível, o sisal.

Outro ponto interessante deste projeto é que foi possível acompanha-lo em fases distintas: elaboração, construção, uso, desconstrução e estocagem. Desta forma foi possível observar diferentes estágios de construção e interação com o objeto.

\subsubsection{Construção do túnel}

A primeira tarefa da construção foi separar os fios de sisal. Com varetas lisas e cilíndricas de madeira ou com varetas de bambu até $1 \mathrm{~cm}$ de diâmetro começamos a bater os chumaços do fardo de sisal no ar para que as fibras fossem se soltando. Durante o processo de fabricação, nossos movimentos gestuais produziram "nuvens" de sisal (Figura 124). 


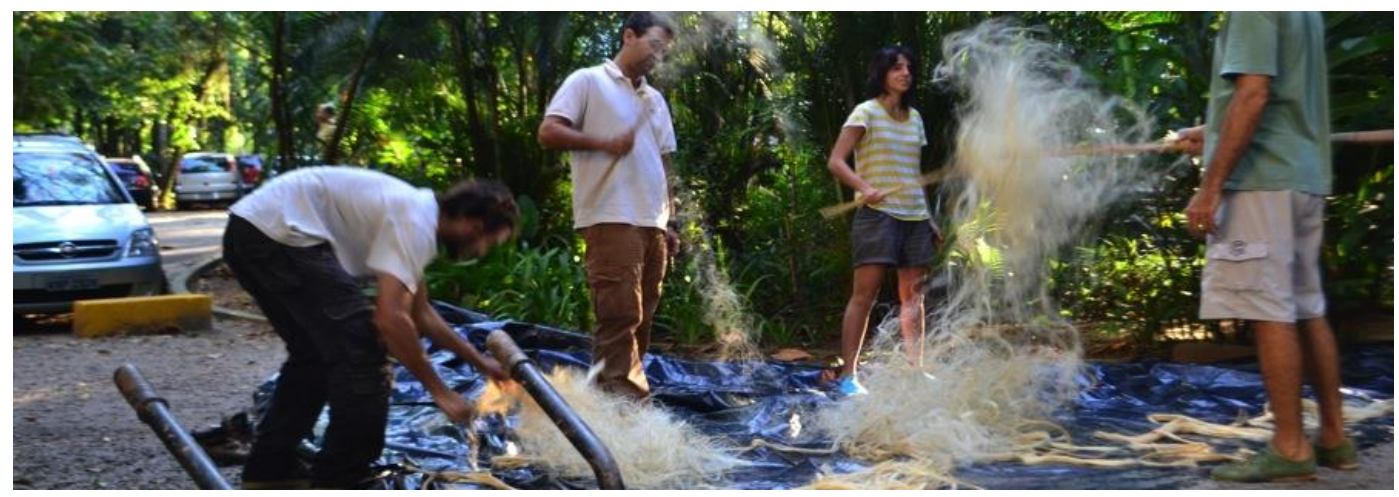

Figura 124 - Processamento das fibras de sisal.

$\mathrm{Na}$ verdade a ação de separar as fibras de sisal produziu, mesmo que involuntariamente, a reorganização das fibras de sisal que ficaram aleatoriamente arrumadas e não mais em apenas um sentido como antes. Como esta construção era de grande porte e o tempo de construção era relativamente curto, o barro foi processado em uma betoneira enquanto os voluntários produziam as fibras de sisal e fabricavam os compósitos.

A maneira convencional de se misturar barro e fibras da maioria das técnicas de construção com terra crua é de separar o barro como matéria primária e ir acrescentando fibras até o ponto que se considerar ideal. $\mathrm{Na}$ construção do Túnel Expositor, como as fibras eram extremamente longas, cada fio de sisal tinha mais de um metro, o acréscimo de mais fibras ao compósito era bem mais difícil, ainda mais compósitos de espessuras mínimas e regulares como foi a proposta. Quando as fibras eram acrescentadas depois, a dificuldade em fazer com que o novo conjunto de fibras mesclasse com as demais de forma eficiente era grande. Na maioria das vezes havia delaminação e não feltragem.

O processo de fabricação precisava ser invertido. As fibras foram organizadas para serem utilizadas formando a manta acrescentando o barro úmido formando o compósito. Caso a manta inicial de fibras tivesse falhas visuais de concentração de fibras, a solução encontrada foi puxar as fibras de um ponto que estivesse em abundância para distribuir e feltrar pela área a ser coberta e seu entorno.

Para aplicar o barro sobre as fibras já prontas e organizadas, a técnica desenvolvida foi com movimentos rápidos do pulso para facilitar a imersão do barro na manta de fibras. A experimentação ajudou a perceber que era mais eficiente, após essa movimentação, usar os dedos e a palma da mão para pressionar o barro na manta, para que pudesse ocupar os espaços entre as 
fibras. O gesto seguinte era a retirada do excesso de barro, com os dedos em forma de concha.

Quando o compósito era virado, era possível perceber os pontos onde o barro ainda não havia feito o contato ou que este contato ainda era muito superficial. Nesse momento o compósito era novamente pressionado com as pontas dos dedos. Esse processo era repetido mais uma vez na face anterior antes de ser aplicado.

O manuseio do compósito em torno do próprio eixo para aplicar o barro do outro lado e para aplicador sobre a estrutura também continham uma metodologia particular (figura 125). Neste ponto da pesquisa a lona plástica já era utilizada como interface do compósito. Como o comprimento das placas para o túnel era relativamente maior do que os experimentos anteriores, cada placa tinha aproximadamente $40 \mathrm{~cm}$ de largura por 1,5 m de comprimento, hastes de bambu ou metal foram utilizadas para facilitar a movimentação com das mantas compósitas.

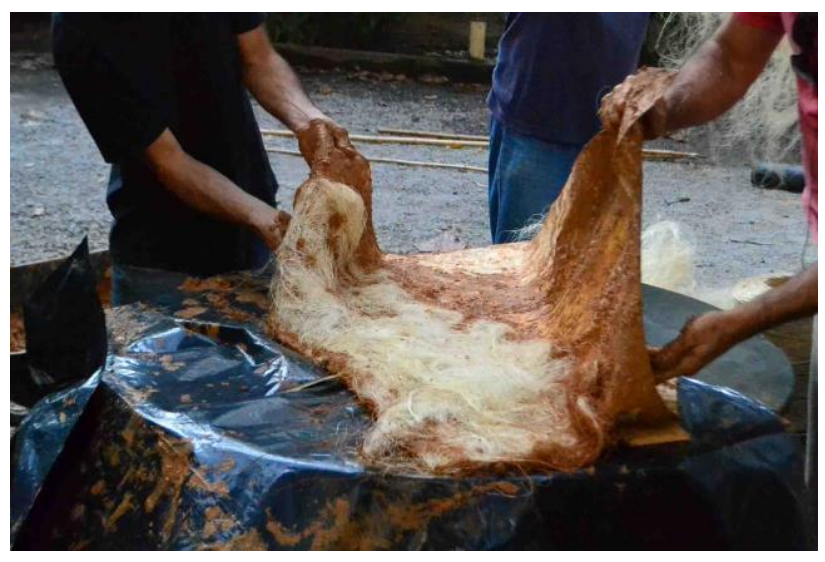

Figura 125 - Movimento de virarmos o compósito para aplicar barro do outro lado. O gestual foi aprimorando a partir da prática

Nessa experimentação é que foi desenvolvida a técnica de retirada do plástico-lona que servia de interface para aplicação dos compósitos (Figura 126). As primeiras mantas que foram feitas continham muita água. Ao manusear o compósito, este tinha a tendência de grudar no corpo alterando a união à tela molde. O uso do plástico facilitou a aplicação de pressão para a manta aderisse à estrutura. A retirada do plástico com movimento cuidadoso e o mais tangente possível à estrutura foi a maneira mais suave encontrada para retirar a lona sem afetar os compósitos.

As mantas de grande porte foram possíveis porque a manufatura dos compósitos foi feita quase que exclusivamente pelos pesquisadores e funcionários do LILD que, mesmo sem todos terem a experiência direta em 
construir com fibrobarro, tinham um olhar e um manuseio mais atento. A construção pôde ser com relativa rapidez.

Antes de construir cada manta, seu tamanho era medido. Para isso, foi construído um molde que era regulado antes de cada compósito ser feito. Durante o processo de construção, usávamos este molde para controle de dimensões.

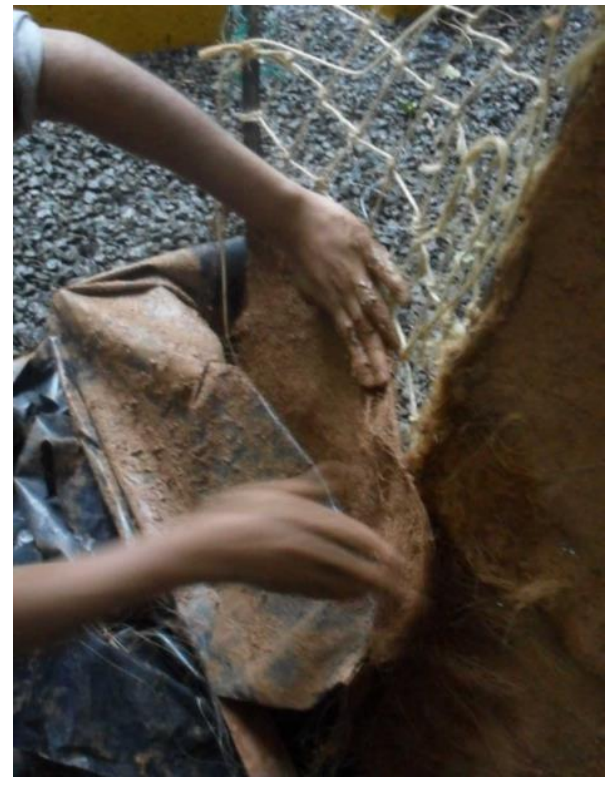

Figura 126 - Cada placa era construída especificamente para o local que seria aplicada.

A construção de cada módulo iniciou-se pela base e foi subindo de maneira homogênea até o topo. Cada nova manta aplicada sobrepunha cerca de 5 a $7 \mathrm{~cm}$ sobre a anterior. Na parte superior de cada manta era feita uma espécie de bainha para ajudar na fixação da manta no molde.

$\mathrm{Na}$ manhã seguinte à aplicação era mais fácil pressionar determinados pontos das mantas para esta se unir mais à rede que servia de molde. Em muitas ocasiões essa ação era feita com duas pessoas pressionando o mesmo ponto simultaneamente. Nesses momentos o potencial de isolamento acústico pôde ser percebido. A comunicação verbal nem sempre era possível. O ponto de pressionamento deveria ser combinado anteriormente.

A estrutura foi montada em três módulos (figura 127), o primeiro módulo foi o do centro. Depois, cada lado recebeu mais um módulo. Mesmo durante a construção, foi possível perceber que o resultado final de cada módulo seria diferente. O primeiro, como tudo que é feito pela primeira vez, apresentou algumas questões que foram superadas ou melhoradas no segundo módulo. O terceiro módulo, parte devido à urgência, parte pelo fato das novas pessoas não 
terem participado, ou ficado atentas aos módulos apresentou algumas questões anteriores, apresentou algumas questões que o segundo módulo não havia apresentado.

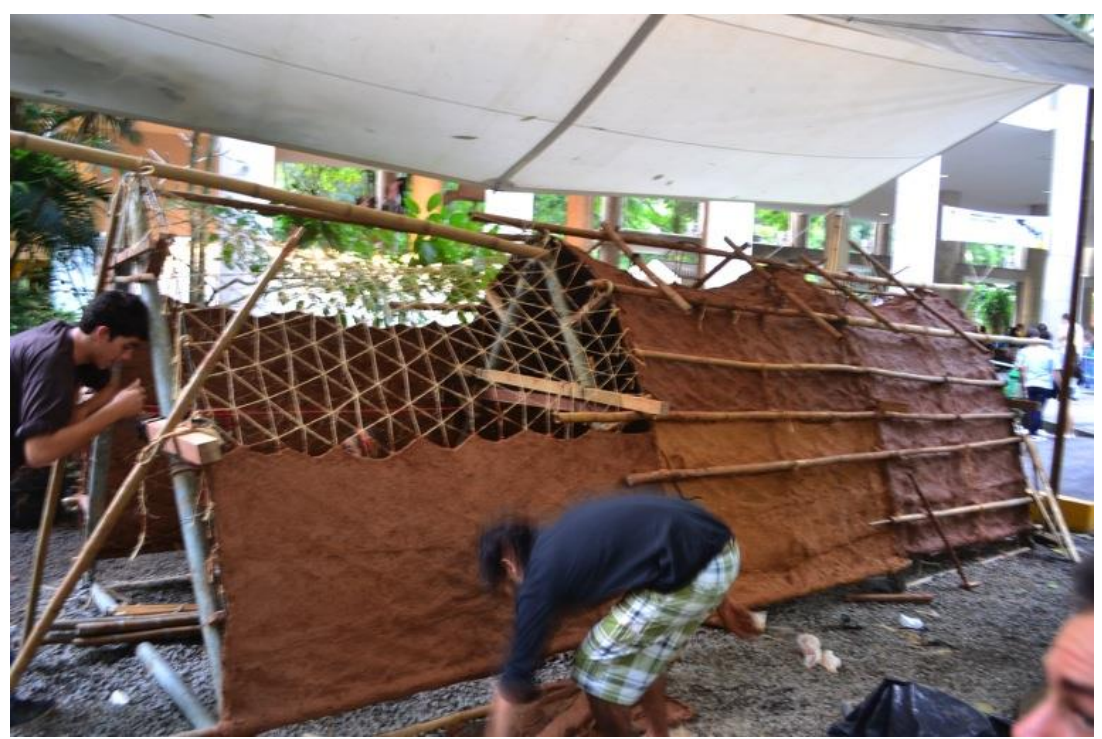

Figura 127 - Terceiro módulo sendo construído enquanto os dois primeiros secavam.

Um indicativo de que a casca tinha ou não sido feita com cuidado era perceptível ao entrar no túnel. Lá era possível ver, a contraluz, pequenos pontos de luz espaçados. Estas pequenas frestas eram visíveis somente de determinados ângulos. Vale ressaltar que não havia incidência de luz dentro do túnel, até mesmo porque este não recebia luz do Sol diretamente.

A maior questão encontrada foi a respeito do vão entre as duas hastes de ferro que ajudavam a dar forma à estrutura, o tempo de secagem foi surpreendente. Em pouco mais de dois dias uma placa já estava seca, mas em dias chuvosos, embora não houvesse incidência direta de chuva, as cascas apresentavam um leve amolecimento ao tato. Presumimos que isso tenha acontecido pelo excesso de fibras, e pequena espessura, diferente das construções tradicionais que costumam ter paredes espessas.

O Túnel atraiu olhares curiosos mas nem todos quiseram experimentar entrar dentro para ver as miniaturas expostas (Figuras 128 e 129). Aqueles que quiseram se aventurar relataram um cheiro particular e também um abafamento dos sons externos. Quanto ao cheiro, provavelmente foi alguma questão da umidade do solo, que a casca de barro ainda retinha. A respeito do isolamento 
acústico, foi surpreendente perceber que cascas de tão pequena espessura pudessem produzir este efeito.

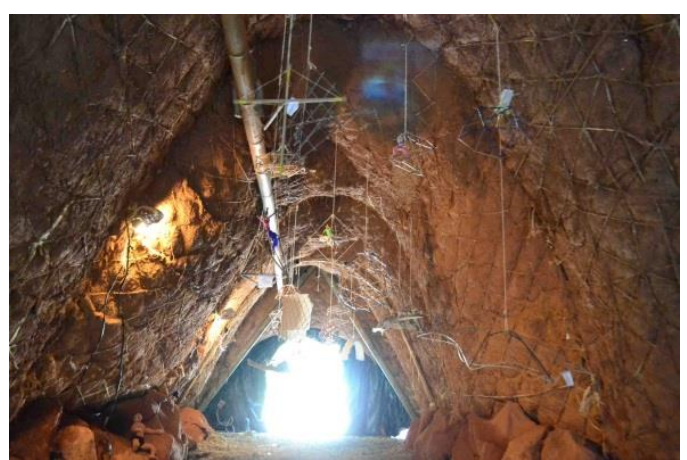

Figura 128 - Túnel Expositor visto de dentro

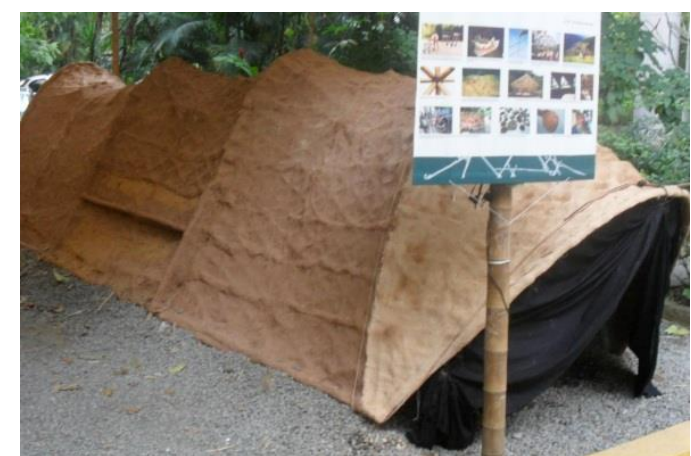

Figura 129 - Túnel Expositor visto da entrada

\subsubsection{Uso da Pastacal como proteção do túnel.}

Como toda a construção do LILD, esta também havia sido elaborada e construída pensando-se no mínimo de material, pensamos que o capeamento também devia seguir princípios análogos. Dentre os elementos pesquisados, a pasta de cal hidratada ainda era praticamente desconhecida, no LILD, mas já despertava interesse da equipe.

Obtivemos uma mistura de água, barro e pastacal (razão volumétrica de 1:2:2) para aplicar nas entradas. Com a mistura o a coloração da mistura não era tão contrastante com o resto da estrutura (Figura 129). Vale lembrar que tanto a pastacal quanto o barro já continham água na sua mistura.

Para aplicar a pastacal foi utilizado um pincel. Essa mistura pastosa serviu para não dar uma coloração diferente da entrada em relação ao resto da estrutura. Após a hidratação da superfície base, o pincel foi usado com movimentos buscando espalhar a mistura homogeneamente sobre toda a superfície (Figura130). 


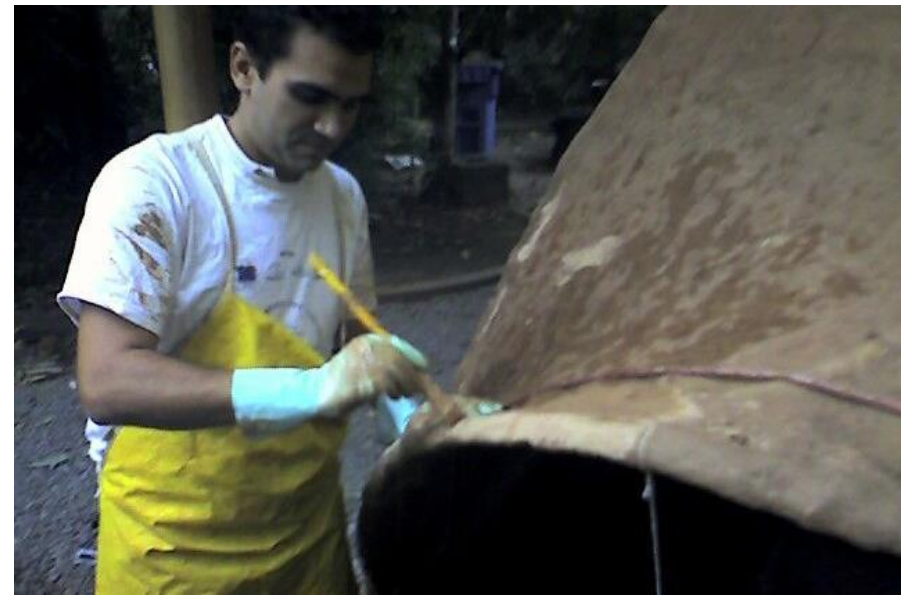

Figura 130 - Aplicação da pastacal utilizando pincel

Após a secagem, era perceptível, pelo menos visualmente, e em testes empíricos de hidratação, uma absorção mais rápida da região que recebeu a camada de pastacal, mas o verdadeiro teste ocorreu dois dias após a aplicação da camada de pastacal. Uma frente fria chegou ao Rio de Janeiro, promovendo uma forte chuva por alguns dias. Após algumas horas de chuva, uma das entradas do túnel era visível algumas fibras de sisal ficando aparentes (Figura 131).

Inicialmente imaginou-se que a chuva indireta estava promovendo esse fenômeno. Somente após iniciada a aplicação de uma segunda camada de pastacal, desta vez mais grossa e utilizando uma espátula, é que foram visualizadas marcas pingos, de cerca $5 \mathrm{~mm}$, sobre a estrutura (Figura 133). Localizamos o galho de uma árvore próxima, que estava conduzindo água sobre o túnel.

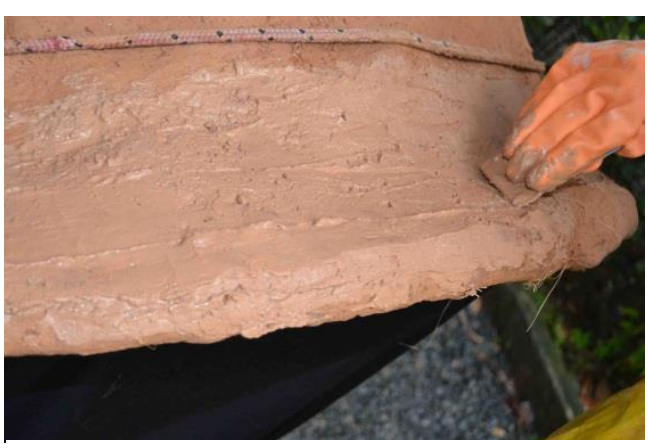

Figura 132 - efeito do gotejamento sobre a estrutura

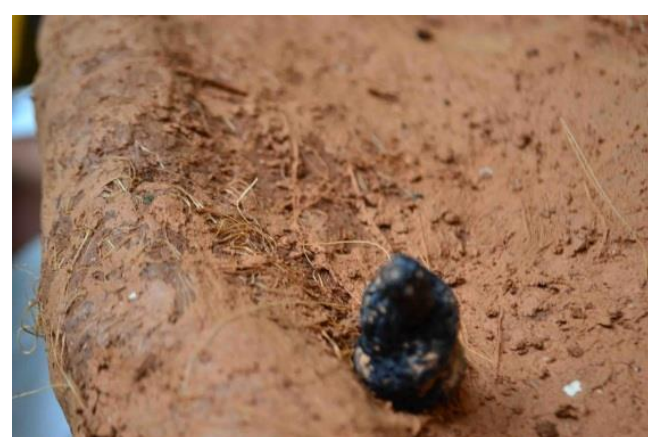

Figura 131 - Aplicação da pastacal mais grossa utilizando

Essa segunda camada, como era de se esperar, apresentou algumas fissuras que foram cobertas utilizando o mesmo processo que fizemos com as 
esferas (Figura 41, página 65). Essa segunda camada tinha cerca de $1 \mathrm{~cm}$ de espessura e ficou cerca de 1 dia e meio protegida debaixo de um tecido até que foi descoberta após a passagem da chuva. A nova camada de pastacal ficou alguns dias exposta ao tempo quando uma nova frente fria chegou à cidade. Novamente a mesma goteira produziu estragos similares aos ocorridos anteriormente (Figuras 133 e 134).

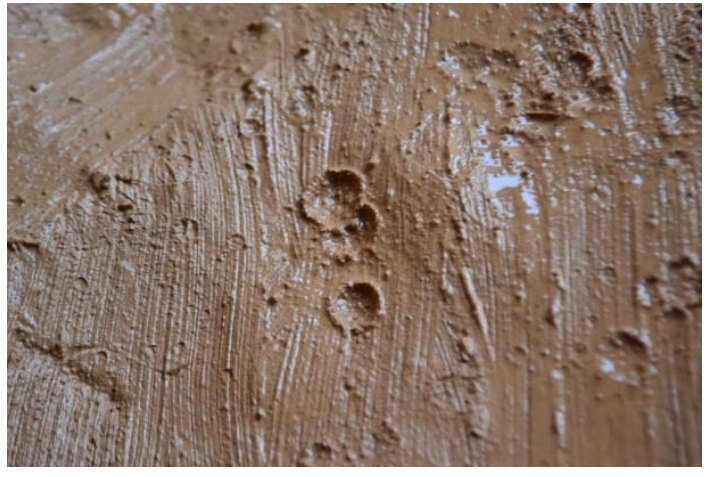

Figura 134 - Gotas de $1 \mathrm{~cm}$ de diâmetro marcando a superfície da estrutura enquanto não estava seca.

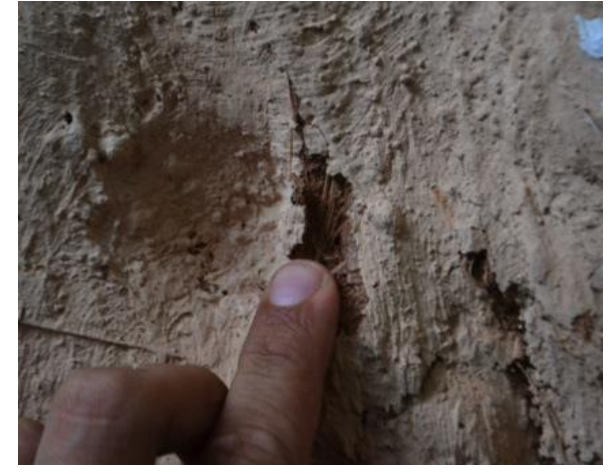

Figura 133 - Após a secagem os efeitos eram ainda mais visíveis.

À princípio, achou-se que a pasta de cal hidratada não tinha resistência para contato com a água acelerada pela queda. Por outro lado, a pasta cal não teve tempo de secar completamente antes de receber as primeiras gotas d'água.

\subsubsection{Desconstrução}

Um dos pontos mais instigantes da construção do Túnel de fibrobarro foi a oportunidade de desmontá-lo algumas semanas depois. Como foi dito pelo nosso orientador, esta etapa não era de desconstrução ou de demolição, mas o início da construção da estrutura seguinte que iria utilizar as cascas de fibrobarro.

A equipe que atuou a maior parte do tempo na desconstrução foi formada por voluntários que viram o Túnel na exposição. Eram estudantes da graduação da PUC-Rio e de outras instituições que há pouco tempo haviam feito cursos sobre permacultura e construções com barro cru e queriam aprender mais sobre o assunto. Além disso, não tinham qualquer familiaridade com a técnica de fibrobarro. 
O método desenvolvido para a desconstrução foi de hidratação suave da região onde iria ser feita o desmolde (Figura 135). Para isso, foi utilizado um pulverizador manual que, distanciado de $40 \mathrm{~cm}$ de distância da superfície, hidratando homogeneamente a superfície sem encharca-la.

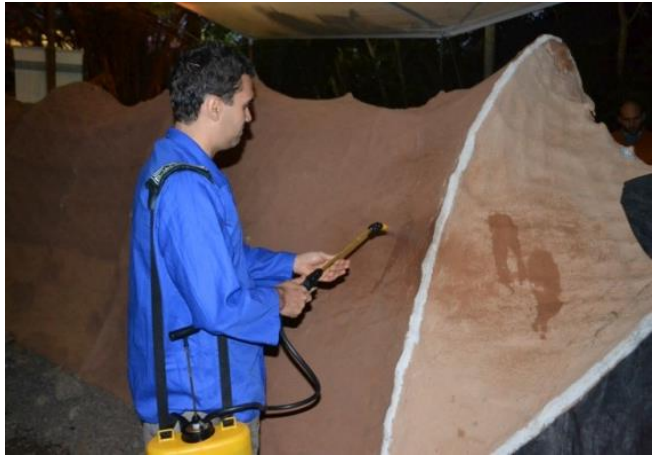

Figura 135- Hidratação da parede

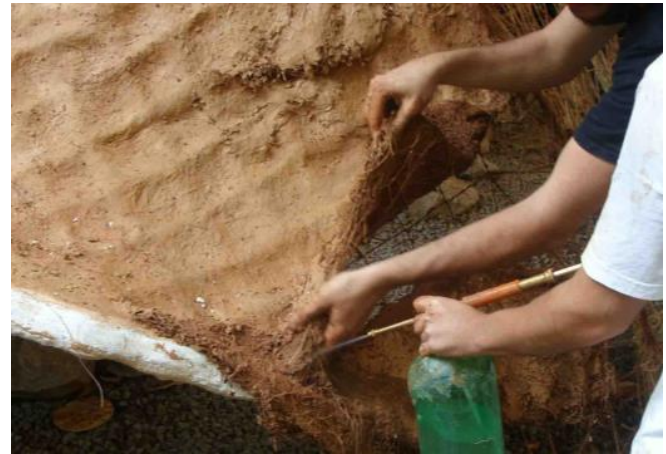

Figura 136- Hidratação e retirada das placas.

Após a hidratação, o compósito ficava mais moldável as dobras eram desfeitas para desengatar da corda ou do vergalhão e puxar a manta (Figura 136). Depois de livre, a manta era apoiada sobre uma lona plástica (Figura 137) e, em seguida, com um bambu de $10 \mathrm{~cm}$ de diâmetro era enrolada como um carretel (Figura 138).
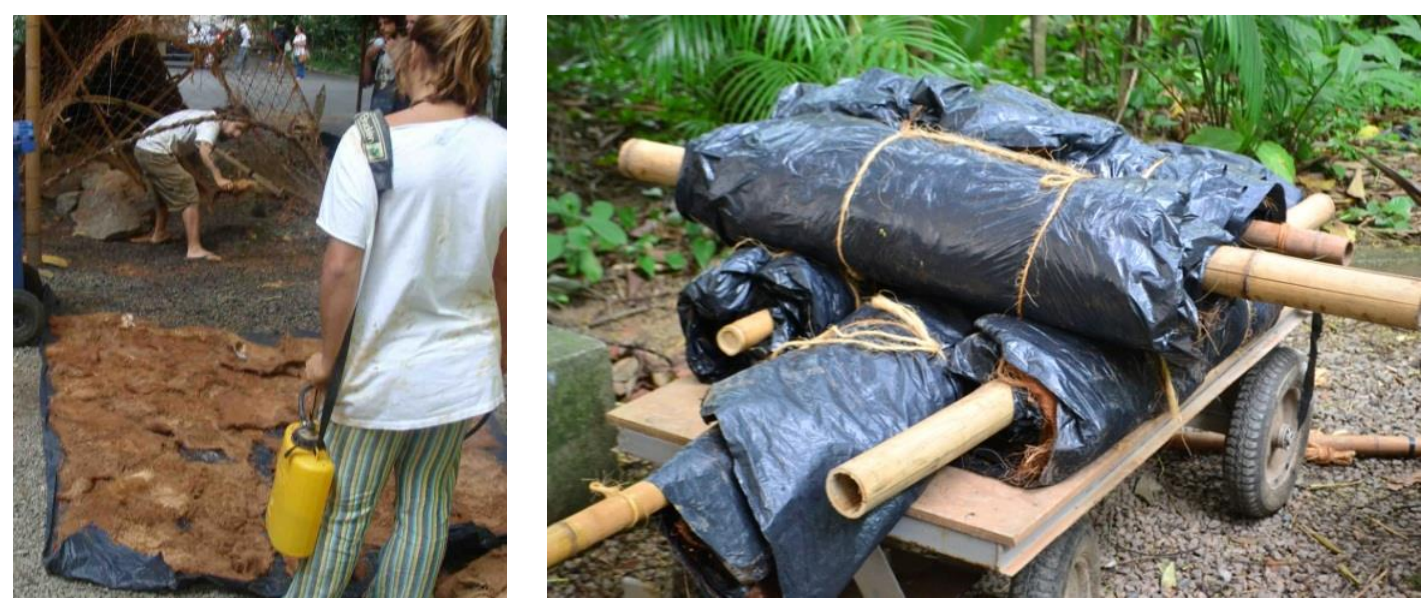
A intenção inicial era armazenar esses carretéis e manter o fibrobarro úmido para facilitar a sua reutilização. Ao longo do tempo a qualidade do compósito foi-se deteriorando ao ponto de grande parte do compósito perder suas propriedades e ficar extremamente frágil. Provavelmente a umidade por um longo período ou em excesso, tenha deteriorado as fibras a ponto destas perderem suas propriedades mecânicas.

Mesmo assim, foi possível reutilizarmos cerca de $50 \%$ do material para realizar outras experimentações suspeita do fibrobarro não poder ser mais usado depois de longo período armazenado foi contrariada.

Figura 138 - Fibrobarro retirado apoiado sobre lonas.

\section{Figura 137- Carretéis de fibrobarro para} estocagem e futura reutilização

\subsection{Demonstração da técnica do fibrobarro na Rio+20}

Durante a Conferência das Nações Unidas sobre Desenvolvimento Sustentável, também conhecida como Rio+20, o LILD foi convidado para expor seus trabalhos no cais do porto, junto com empresas e outros centros de pesquisa que buscam soluções sustentáveis.

Nessa exposição, além de painéis com pesquisas realizadas em outros anos, a equipe montou um stand baseado nos estudos de superfícies mínimas da bolha de sabão em base quadrangular (Correia de Melo, et al. 2012). Esse era o foco da pesquisa do Laboratório naquele momento. O ambiente foi construído com fitas de bambu amarradas com cordas de polipropileno (Figura 139).

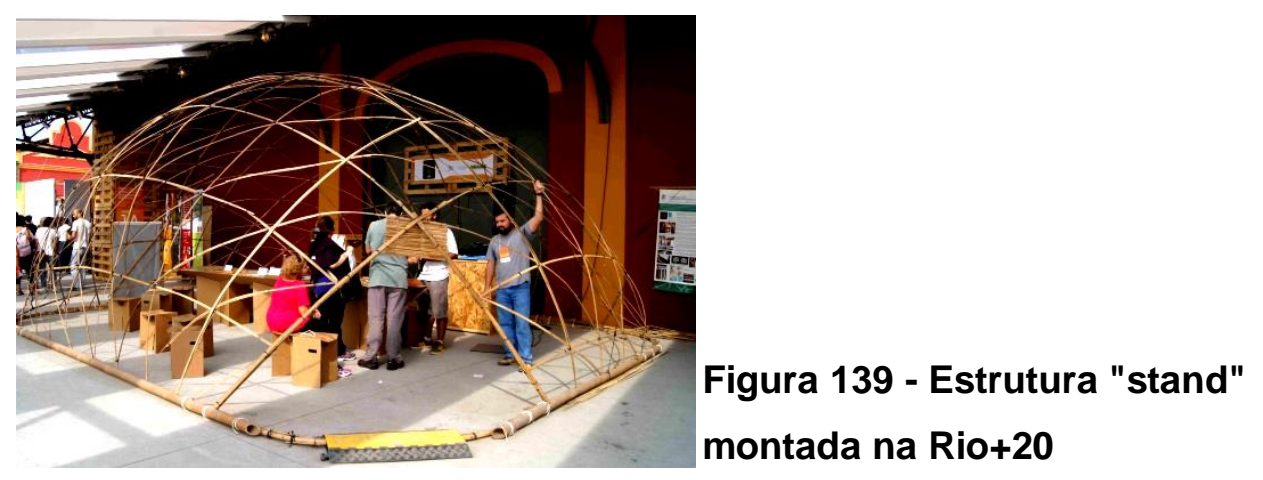

Durante a exposição, os pesquisadores ali presentes faziam demonstrações para os visitantes dos princípios estudados e as justificativas para o estudo da bolha de sabão e sobre o uso do bambu. Em um dos dias da 
exposição foi feita uma demonstração de fabricação e construção com o fibrobarro.

Um dos pontos interessantes desta demonstração é que por ser um espaço público, com centenas de pessoas circulando por muitos dias, a oficina teve que ser realizada produzindo o mínimo de resíduos. Mínimo de sujeira, inclusive nas roupas dos participantes que não estavam preparados para lidar com o barro ao saírem de casa (Figuras 141 e 142).

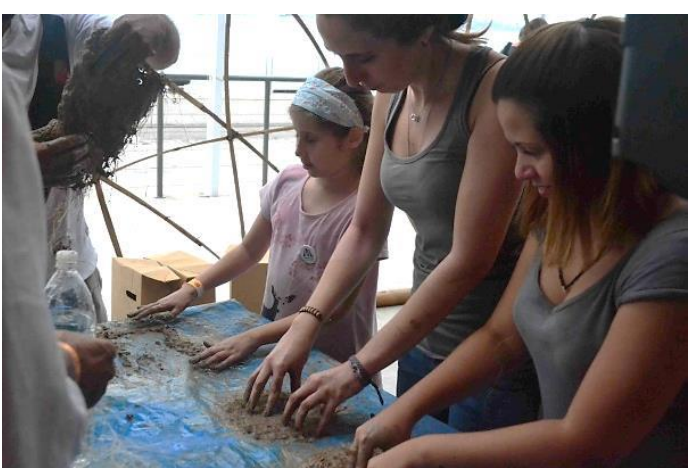

Figura 140 - Voluntárias construindo pequenas placas.

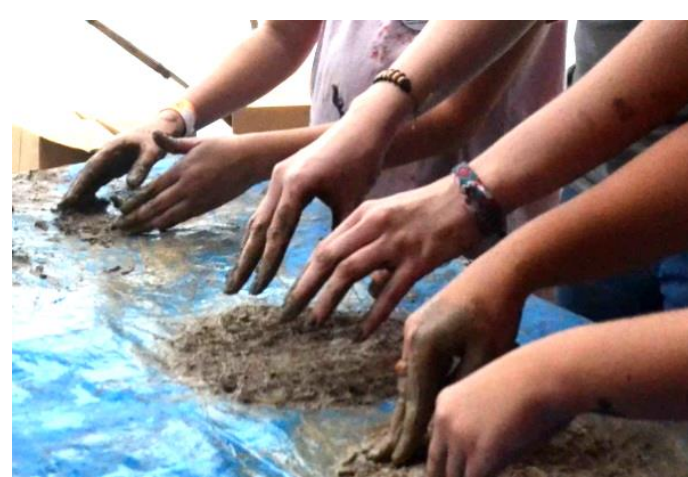

Figura 141 - Detalhes para que praticamente só as pontas dos dedos atuam.

As experiências com fibrobarro, especialmente na construção do Icosaedro da Fazenda Faraó (RJ, página 120) mostrou que era primordial diminuir os vãos e estabilizar ao máximo o local de aplicação do fibrobarro. Como a desmontagem aconteceria poucos dias depois do evento fizemos a aplicação sobre uma manta de juta para facilitar o desmolde.

Após a diminuição do vão e com a quantidade de ripas de apoio, foi feita uma demonstração com os visitantes da Feira. Neste contexto, a produção de fibrobarro foi bem similar ao mostrado no Túnel Expositor. A diferença foi que a utilização de água foi a menor possível para evitar que os praticantes e o ambiente se sujassem em demasia. O processo de construção foi bem mais lento, mas, em compensação, o desperdício de material foi muito menor (Figura 143).

A média de participação dos voluntários não foi superior a 30 minutos mas duas jovens, participaram da atividade por mais de uma hora. Um verdadeiro recorde, já que a maioria das atividades na exposição era muito rápida. Chegaram a comentar que haviam deixado de visitar outras partes da exposição por estarem tão envolvidas naquela ação de construir. A escolha delas deu oportunidade de um aprendizado muito mais profundo e consciente. 


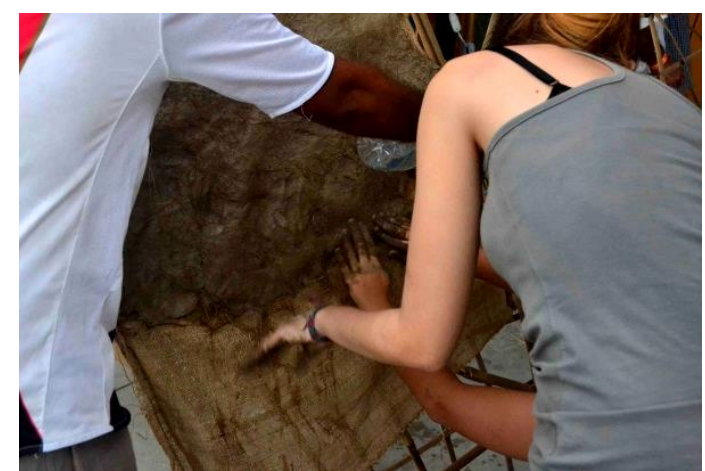

Figura 142 - Aplicação do fibro barro na estrutura

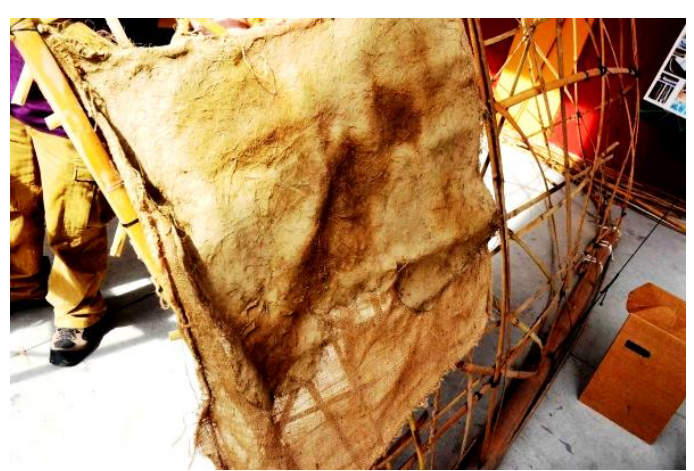

Figura 143 - Fibrobarro sobre juta sobre a estrutura

No dia da desmontagem da estrutura a casca foi retirada inteira apenas com a remoção dos bambus que diminuíam os vãos. Durante o processo de secagem da casca, esta cedeu um pouco perto dos vãos, formando sulcos (Figura 144). Esses afundamentos ajudaram no travamento do compósito à estrutura. Contudo, caso a estrutura fosse ficar exposta ao tempo, estes locais seriam pontos acúmulo de água.

\subsection{Experimentações na Fazenda Faraó - Cachoeiras de Macacu (RJ)}

A Fazenda Faraó, localizada no município de Cachoeiras de Macacu (RJ), é um espaço que ao longo do ano recebe grupos de diferentes idades. Neste espaço acontecem atividades de entretenimento e educação ao ar livre, estimulando o contato com a natureza. Todas as construções feitas neste sítio, no interior do Estado do Rio de Janeiro seguem o princípio de utilizar os recursos locais para fazer construções mais eficazes com baixo consumo energético.

Ao longo do ano, além dos funcionários do local fazerem vários tipos das chamadas construções ecológicas, é comum visitantes irem até lá para participar de oficinas de bioconstrução. Com isso tivemos a participação de três grupos distintos em muitos experimentos.

Um dos grupos foi formado por funcionários da fazenda. São homens nascidos e criados no local com uma escolaridade baixa, mas muito acostumados a fazerem trabalhos manuais e com alguma experiência em construções ancestrais como pau-a-pique e outras técnicas. É importante lembrar que apesar de terem esta proximidade maior, não são praticantes assíduos destas técnicas.

O segundo grupo foi de alunos e ex-alunos da PUC-Rio, que fizeram a disciplina Tópicos Especiais em Design - Bambu. Estes alunos que tinham 
pouca ou nenhuma experiência com terra crua sendo que, em sua grande maioria, entre 18 e 29 anos oriundos, também em maioria, de famílias de classe média e classe média-alta. O perfil da maioria desses alunos é da área de Ciências Humanas.

A Fazenda Faraó também funciona como espaço de colônia de férias e passeios pedagógicos, recebendo ao longo do ano, principalmente durante as férias escolares, grupos de estudantes entre 8 e 15 anos de classe média e classe alta da cidade do Rio de Janeiro e arredores. Essas crianças e adolescentes vêm de um contexto no qual não precisam trabalhar, pois os pais têm condições financeiras estáveis o suficiente para enviarem os filhos em viagens desacompanhados. Essas crianças e adolescentes nunca haviam feito qualquer atividade semelhante.

De acordo com os objetos construídos o público que participou da atividade será melhor descrito.

\subsubsection{Módulos icosaédricos}

Foi produzido um icosaedro regular, com varas de 2,7 m, para construir uma casinha para as crianças que frequentam a Fazenda Faraó. Esta construção possibilitou a observar a atuação de dois grupos distintos sobre a estrutura: os alunos da PUC e os funcionários da Fazenda Faraó. Os voluntários construíram a estrutura e iniciaram a aplicação que foi finalizada pelos funcionários.

\subsubsection{Primeiro encontro de estudantes}

O primeiro encontro serviu para construção da estrutura base. Os estudantes coletaram, limparam, marcaram e amarraram os bambus para formar o icosaedro regular. Após a construção, o tamanho dos triângulos formados foi medido para, durante as aulas na PUC-Rio, construírem a grade de ripas de bambu que receberia o fibrobarro. Estas ripas foram obtidas com o uso de uma faca estrelada que ajudou a acelerar o processo. 


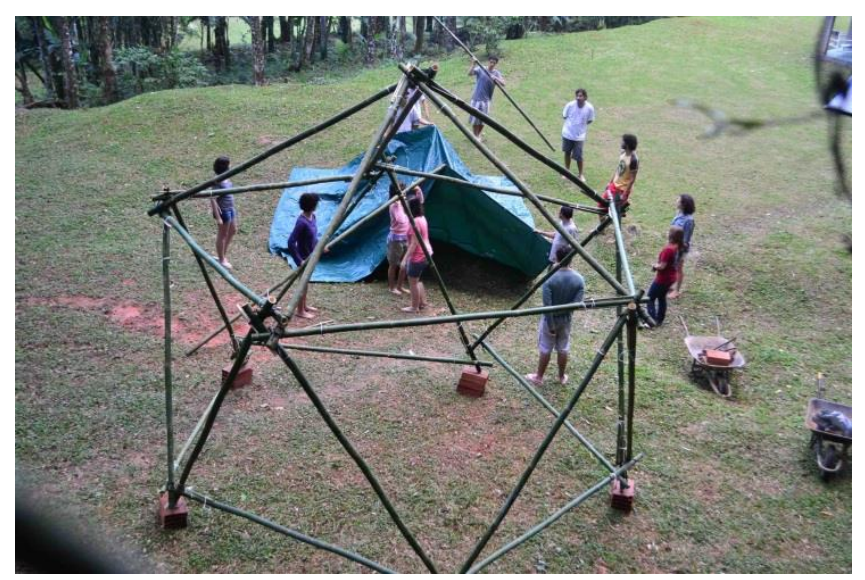

Figura 144 - Esqueleto inicial do Icosaedro

Para preservar, uma lona foi estendida sobre a estrutura para que a construção continuasse sem a preocupação com as eventuais chuvas que surgiriam. A lona foi grande o suficiente para cobrir toda a área da estrutura sem que ela recebesse qualquer chuva direta.

\subsubsection{Segundo encontro dos estudantes}

A segunda etapa ocorreu cerca de 40 dias após a primeira. Nesse intervalo a equipe de funcionários da Fazenda Faraó construiu apoios para elevar a estrutura do chão. Estas "estacas" foram feitas de concreto contido por tubos de papel que originalmente foram usados como miolo de bobinas de tecido.

Para facilitar a colocação das mantas, os planos inclinados do icosaedro foram aproveitados. A técnica consistiu em colocar o fibrobarro sobre o lado que tivesse inclinação à favor. Quer dizer, as mantas maiores nos lados que a gravidade facilitasse a união entre as ripas e os compósitos.

Usando as ripas coletadas na viagem anterior, os estudantes começaram a construção das paredes. Logo foi percebido que o distanciamento entre os bambus ainda era grande demais, cerca de $15 \mathrm{~cm}$. Para tornar a estrutura mais estável mais ripas foram acrescentadas.

O espaçamento entre as ripas foi o maior desafio, pois quando a treliça trepidava, favorecia o desprendimento das mantas de fibrobarro feitas com folhas de bambu e grama. O que também pode ter facilitado o desprendimento foi uma chuva torrencial que caiu ao longo do dia. Ambos os fatores contribuíram para o ritmo lento da produção, mas a ansiedade do grupo em fechar toda a estrutura também contribui negativamente.

Esta vontade de construir rápido promoveu a produção da maior placa de fibrobarro que já produzida. Este triângulo com cerca de 1 metro quadrado foi 
aplicado em um dos lados da estrutura. Do outro lado, as pequenas "pizzas" anteriormente mencionada ajudaram a estabilizar o compósito.

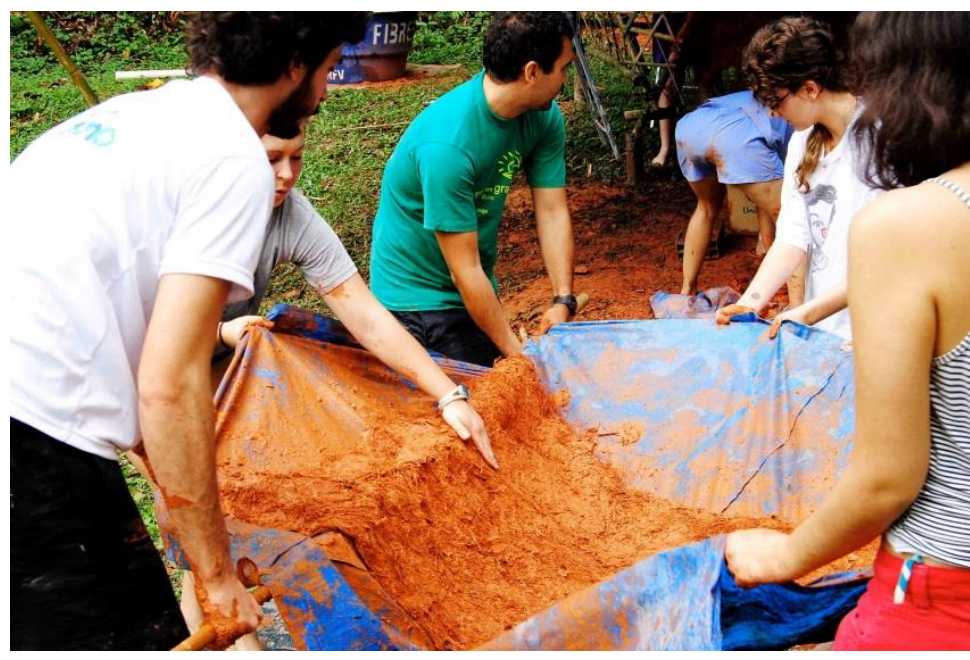

Figura 145 - Grande manta de fibrobarro sendo transportada

Um ponto interessante deste tipo de construção foi a movimentação do grupo. A movimentação de mistura feita com os pés seguia um ritmo quase que de uma dança ou um jogo onde o objetivo era ocupar todos os espaços possíveis. O tom lúdico também se manifestou muito em diversos momentos da atividade e contribuiu para levantar o moral de quando as aplicações dos compostos não atendiam às expectativas.

Mais uma vez, pela inexperiência do grupo a respeito da técnica e do material, fez com que um cerca de 10 pessoas, em 12 horas de atividade, cobrisse pouco mais de um oitavo da estrutura pretendida.

\subsubsection{Terceiro encontro: Mutirão}

A vontade de finalizar a estrutura fez com que um grupo de 8 voluntários reunisse por uma semana para tentar terminá-la. A intenção era aproveitar o início das férias de fim de ano da universidade para, ao mesmo tempo, descansar e terminar uma estrutura de bambu e barro que pudesse ficar perene. Nem todos puderam participar de todos os dias de atividade e o grupo era responsável por produzir também sua própria alimentação. Por isso é possível dizer que durante 7 dias, 5 universitários trabalharam cerca de 6 horas por dia. na colocação do fibrobarro sobre a estrutura.

A primeira tarefa foi reforçar ainda mais os triângulos. Mais ripas de bambu foram produzidas para entrelaçar a estrutura e aumentar a estabilidade (As figuras 147 e 148 fazem um comparativo). Também foram usadas cordas de 
sisal de $5 \mathrm{~mm}$ para ajudar a unir ripas que estavam com algum espaçamento e aumentar a área de suporte das mantas a serem colocadas.

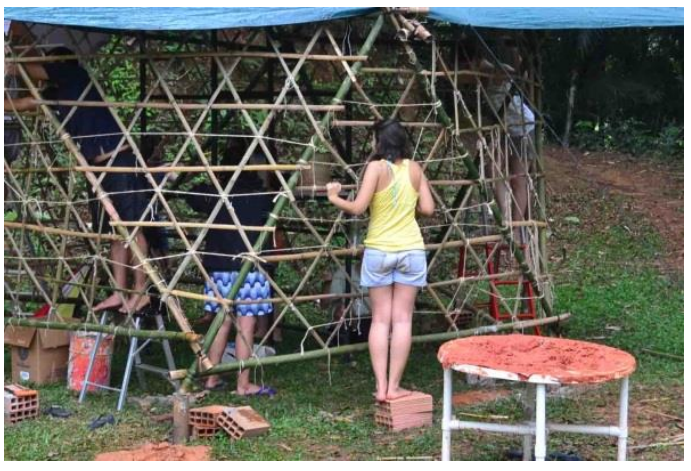

Figura 147 - Quantidade de ripas colocadas na primeira tentativa de aplicar o fibrobarro.

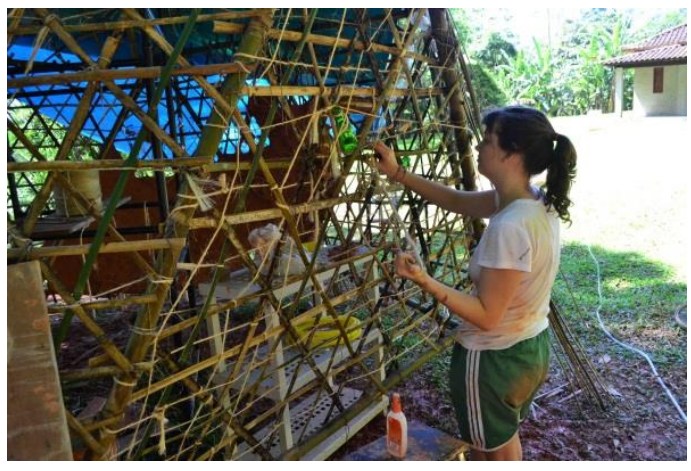

Figura 146 - Quantidade de ripas e cordas na segunda tentativa

A atividade foi iniciada utilizando a técnica desenvolvida na construção do túnel expositor (Figura 125, página 110). Essas mantas tinham $40 \times 60 \mathrm{~cm} \mathrm{e}$, diferentemente do que ocorreu na PUC, foram produzidas por estudantes que já haviam feito mantas fibrobarro e por outros que nunca haviam experimentado procedimento semelhante. Houve uma resistência à técnica de produzir placas de grande porte de ambos os grupos de alunos, principalmente dos alunos que nunca haviam feito a técnica antes. A trepidação da trama de ripas durante a aplicação do fibrobarro influenciou na decisão de utilizar compósitos menores.

Os voluntários foram diminuindo as placas até um tamanho que achassem confortável para trabalhar. Normalmente era um tamanho relativo a dois palmos. Com este tamanho, o controle foi maior e a qualidade do trabalho aumentou (Figuras 148 e 149).

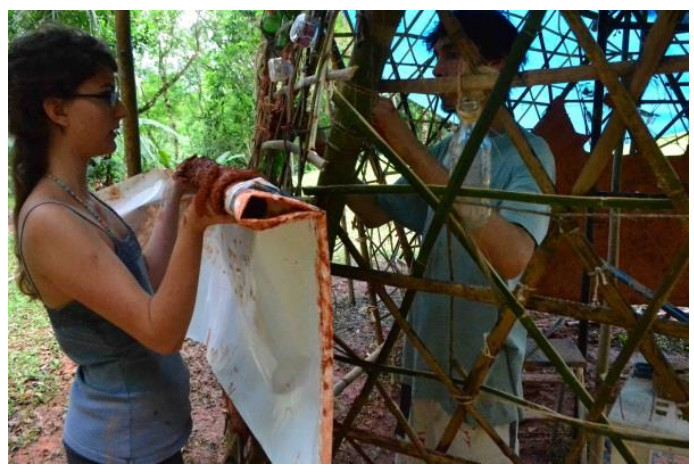

Figura 149 - Voluntário aplicando uma grande placa

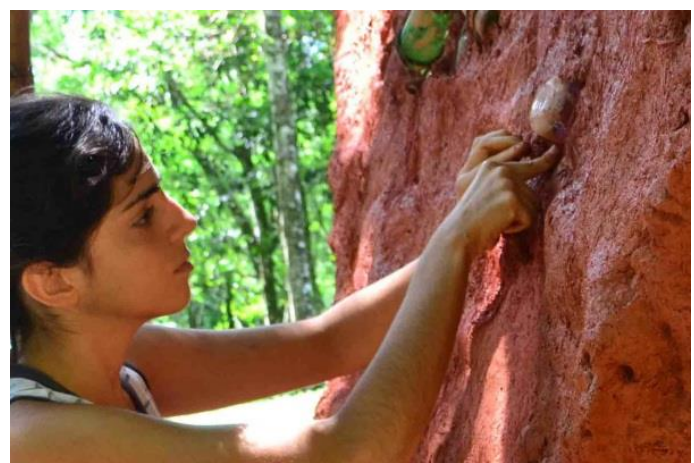

Figura 148 - Ao diminuir o número de placas a qualidade aumentou. 
A prioridade era fazer um trabalho de qualidade e com envolvimento pessoal. Permitiu até a confecção de "bustos" em alguns pontos da estrutura. A produção tornou-se uma tarefa lenta e gradual, mas com qualidade.

Após uma semana de trabalho o grupo produziu a cobertura de 1/3 da estrutura. A partir de então foi a vez de 3 moradores da região, funcionários da propriedade, atuarem na construção.

\subsubsection{Grupo de funcionários}

Esses três funcionários além de já terem visto construções de pau-a-pique serem feitas quando eram crianças, já haviam feito um trabalho de resgate destas técnicas na construção de uma casa de pau-a-pique dentro da propriedade. Por isso, é possível dizer que já eram bem mais especializados que os grupos anteriores. Até mesmo porque, como camponeses que vivem do trabalho de suas mãos, são mais habituados a fazer trabalhos pesados. Com isso o ritmo de produção aumentou sensivelmente.

Apesar da tentativa de introduzir a técnica de produção das mantas, o grupo mostrou-se muito mais apto a produzir da maneira que já tinham confiança. Alegaram que, trabalhando com compósitos do tamanho das mãos, tinham mais controle e o trabalho acontecia mais eficientemente. A homogeneidade da espessura ficou um pouco comprometida, mas o desenvolvimento dos gestos para aplicação diminuiu um pouco as irregularidades.

A técnica desenvolvida por eles foi de aplicar os compósitos de barro e fibras de bambu com mais água que as placas desenvolvidas anteriormente. A mistura utilizada pelos funcionários tornava o compósito extremamente maleável. Outro ponto diferente foram os gestos utilizados. Lembrando os gestos de "chapisco" de cimento eles pegavam um punhado de composto com as mãos, jogavam no ponto desejado, usando a força dos pulsos para então espalhar o excedente com a palma ou com o torso da mão (Figuras 150 e 151). 


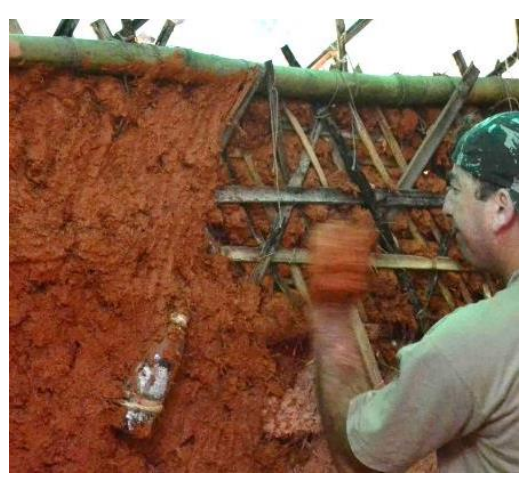

Figura 150 - Uso do punho para aplicar.

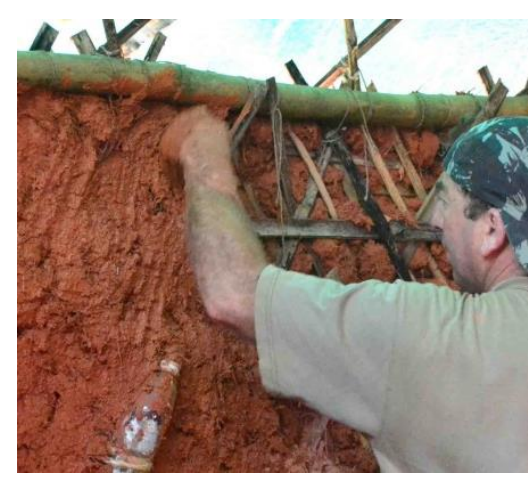

Figura 151 - Uso do torso para alisar.

Outra técnica desenvolvida espontaneamente pela equipe foi a de colocar fibrobarro em um dos lados, o de inclinação positiva, e cobrir os bambus do outro lado apenas no dia seguinte. Desta forma a superfície já aplicada, estava mais firme e apta a receber mais carga. Como o fibrobarro aplicado continha muita água, a reidratação não era tão necessária.

Em poucos dias a equipe de três profissionais cobriu todo o restante da estrutura com exceção da cobertura. Para ajudar a proteger mais a base de bambus foram colocadas pedras e as eventuais frestas foram cobertas com barro úmido.

\subsubsection{Testes de cobertura nas paredes do Icosaedro}

Para o arremate final das paredes do Icosaedro, foi produzida uma película de cal hidratada, homogeneamente misturada com terra peneirada com peneira de $3 \mathrm{~mm}$, que foi aplicada como se fosse uma tinta diluída, ainda com aspecto consistente e aplicada no local. A intenção era observar como a pasta de cal hidratada, misturada com barro e aplicada em forma de película, se comportaria diante da ação principalmente da chuva indireta, já que o local da construção não recebe tanta ação solar ao longo do ano. Para a cobertura, chegamos a produzir alguns protótipos, mas optamos por produzir um telhado feito de folhas de sapê por ser mais rápido de fazer e para observar mais rapidamente o comportamento da mistura cal-barro (1:1) nas paredes (Figura 153). 


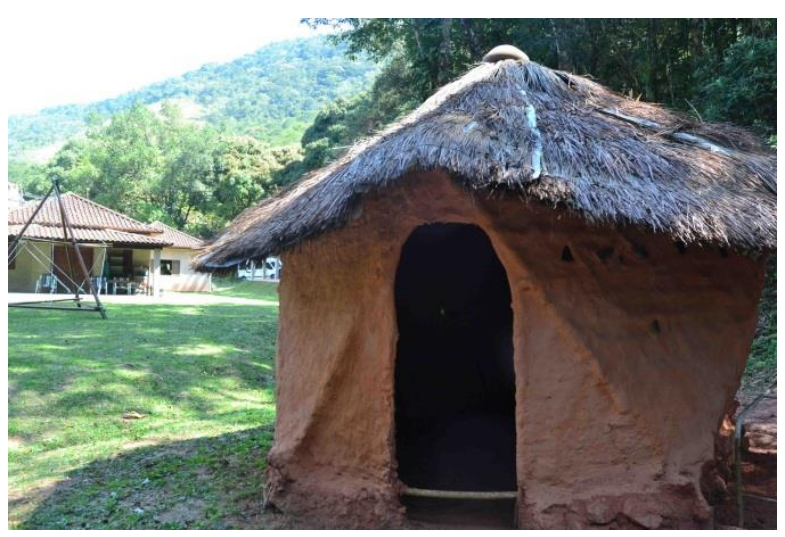

Figura 152 - Icosaedro coberto de pastacal e barro

\subsubsection{O uso depois de pronta}

Protegida da chuva direta e até mesmo da incidência direta do sol, após alguns meses, a cobertura de cal-barro não demonstrou deterioração em grande parte da sua superfície. Em alguns pontos da parte interna e da parte externa, foi possível perceber pequenas fissuras, que podem ter ocorrido por retração do barro ou má aplicação do fibrobarro.

Um ano após a construção, apesar de aparentemente a construção estar em perfeita condições, seu uso ainda é modesto. Talvez pela forma ou por não ter janelas o espaço não foi apropriado. Ele atrai olhares e perguntas de visitantes, mas não é muito utilizado. As exceções são feitas a alguns materiais como andaimes e lonas que são guardadas no local e, na época em que a colônia de férias ocorre, o local é usado como esconderijo por pessoas aqueles que têm algum receio de se esconder na floresta.

De qualquer forma, se for levado em conta que a intenção desta construção também foi a apropriação da técnica e do gestual, podemos afirmar que o objeto cumpriu o seu objetivo. Também serviu para a população local fazer uma ligação entre a técnica do pau-a-pique convencional e as técnicas do LILD. Foi possível ver esta apropriação no estuda de caso da espiral treliça (página 133)

\subsubsection{Telhados de Fibrobarro}

Ao construir com materiais biocompatíveis é de praxe pensar que as paredes devam utilizar materiais que promovam permeabilidade ao ar, ou pelo menos da umidade, com o meio. Contudo quando o assunto é a parte que recebe a maior parte da ação da chuva, o telhado, o desafio é bem maior. O mito do "bom chapéu" para proteger a construção de barro cru faz com que as casas 
que "respiram" tenham isolamento na cobertura para garantir, ou elo menos remediar, a entrada da água. Nesta parte da dissertação serão dois experimentos feitos para tentar encontrar caminhos para a construção de coberturas que não utilizassem lonas de polipropileno, cimento ou telhas de barro cozido.

Enquanto as paredes do Icosaedro ainda eram construídas, começaram a surgir hipóteses para fazer a cobertura. A ideia inicial era fazer com que toda e estrutura de fibrobarro revestido com cal hidratada e observar a ação do tempo. As dificuldades de aplicar fibrobarro nas paredes da estrutura alterou os planos surgindo a possibilidade de pré-produzir as peças. O triângulo principal foi dividido em quatro triângulos equiláteros que pudessem ser sobrepostos para formar a cobertura.

Foi feita uma estrutura triangular utilizando ripas de bambu. A intenção era produzir uma base firme para aplicar o fibrobarro. Este protótipo foi trançado buscando deixar um espaçamento pequeno sem aumentar muito o peso da estrutura.

O passo seguinte foi acrescentar fibras de sisal que foram dispostas procurando fazer com que envolvesse toda a estrutura de bambu entrelaçandoas ao máximo. Uma das técnicas utilizadas foi usar os dedos como pinças para puxar as fibras e permitir que estas se entrelaçassem com a estrutura (Figura 154).

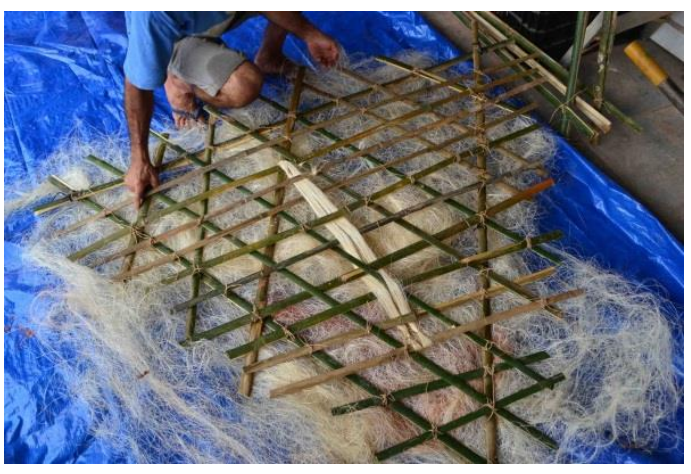

Figura 153 - Entrelaçamento das fibras de sisal na estrutura de ripas de bambu.

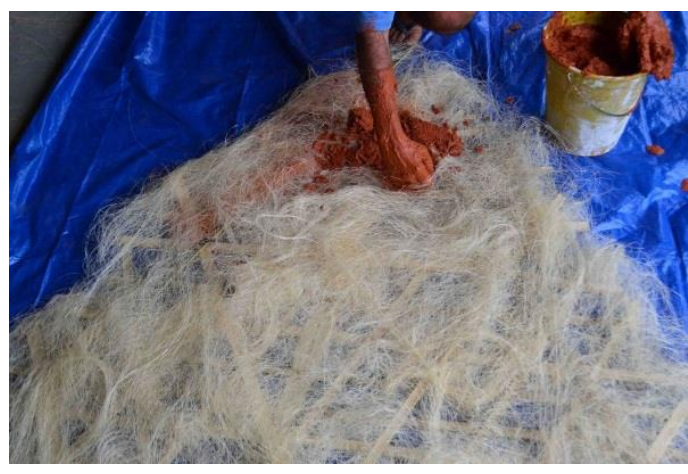

Figura 154 - Aplicação do fibrobarro

Depois, as fibras recebiam uma mistura homogênea de barro com pastacal previamente hidratados (1:1) (figura 155). Analisando os movimentos gestuais utilizados, acreditamos que a quantidade de barro usada neste ponto poderia ter sido reduzida. Uma das maneiras seria aumentar a pressão utilizada para aplicar 
a mistura barro-cal. Assim, utilizando menos barro, o compósito poderia ter ficado mais leve.

Quinze dias depois da aplicação, quando o barro-cal utilizado já estava, visualmente, bem próximo ao ponto de secagem. Ao mover a estrutura, foi possível ver surgirem diversas fissuras por toda a superfície. A quantidade de barro que utilizada aumentou o afrouxamento ligações da treliça que ficou muito flexível.

Foi cogitada a colocação de bambus inteiros como estabilizadores para que a estrutura não curvasse, mas isso também aumentaria a quantidade de barro e o peso do compósito. A solução encontrada foi a construção do telhado de sapê por ser uma tecnologia local com material abundante na região.

\subsubsection{Cobertura da Espiral Treliça}

Os experimentos visando construir uma cobertura de fibrobarro voltaram a entrar em pauta quando os experimentos de laminação foram retomados. Com a laminação, é possível produzir uma casca extremamente fina, resistente e leve de fibrobarro.

Ao construir a espiral treliça com bambu e fibrobarro, surgiu a possibilidade de produzir cascas laminadas como cobertura da construção. Procurando diminuir o peso da estrutura, foram feitos experimentos de laminação de tecido preenchido com barro. Como foi mostrado anteriormente (item 4.1.1, página 49), ao laminar tecidos, é possível produzir uma casca mais resistente. A dúvida era se o vão criado ou a forma seriam eficazes para alcançar a rigidez necessária.

No ponto de origem da espiral, já havia sido posto um mastro de eucalipto, que além de contribuir para a estabilidade da estrutura, serviu como base para a colocação de uma porta. Madeiras roliças extraídas da mata da região foram usadas como caibros. Elas foram pregadas no mastro central e apoiadas sobre as interseções de bambus da treliça (Figuras 156 e 157). Assim, a área a ser coberta ficou dividida em 18 triângulos de base de $50 \mathrm{~cm}$, variando somente 0 comprimento (o maior possui 2,2 m e o menor 1 metro). 


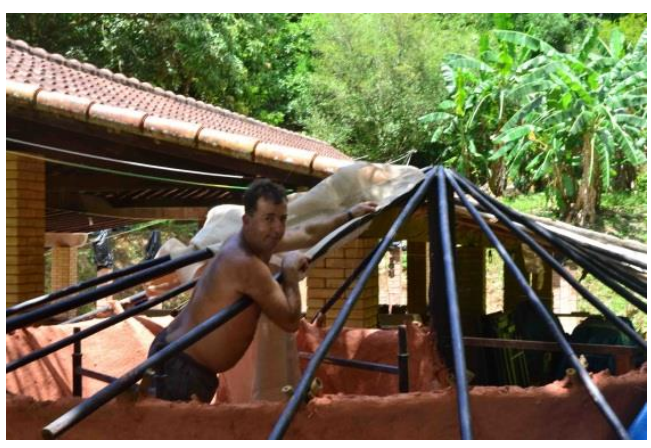

Figura 156 - Caibros apoiados sobre um mastro

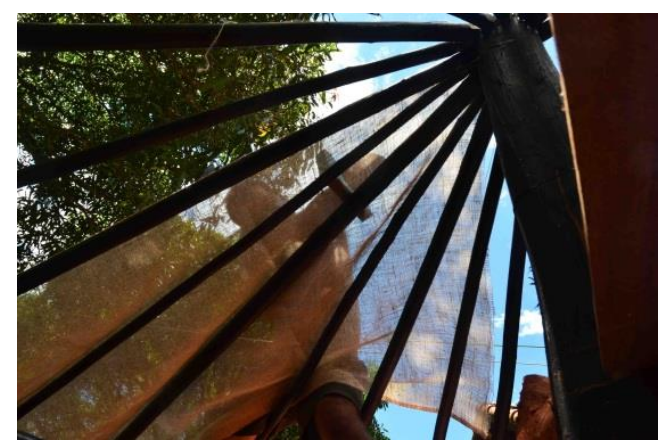

Figura 155 - Vista por baixo da estrutura de telhado

Como primeiro experimento, foi feita a construção da casca diretamente sobre os caibros. A intenção era testar evitando o transporte da casca. Uma manta de juta foi usada para que servisse de superfície-base para as camadas seguintes. Até mesmo porque tem uma grande resistência mecânica à tração. Utilizando uma pistola de grampos foram reproduzidos os gestos para a preparação de uma tela de quadro ou de silk esticando ao máximo o tecido para tencioná-lo, diminuindo ao máximo a formação de "barrigas". Para facilitar a ancoragem das camadas seguintes, utilizando um pincel, cola PVA foi aplicada sobre a superfície.

Um barro bem umedecido foi aplicado utilizando as mãos (Figura 158) que pressionavam para que a penetração do barro no tecido fosse mais eficiente. Nesta ação foi perceptível que o barro utilizado deveria ter sido peneirado por uma peneira ainda mais fina que a utilizada. A peneira de $3 \mathrm{~mm}$ não evitou a passagem de pequenas pedras de quartzo, tornando a superfície irregular. Mesmo assim, o procedimento continuou para observaçã se este detalhe seria realmente crucial.

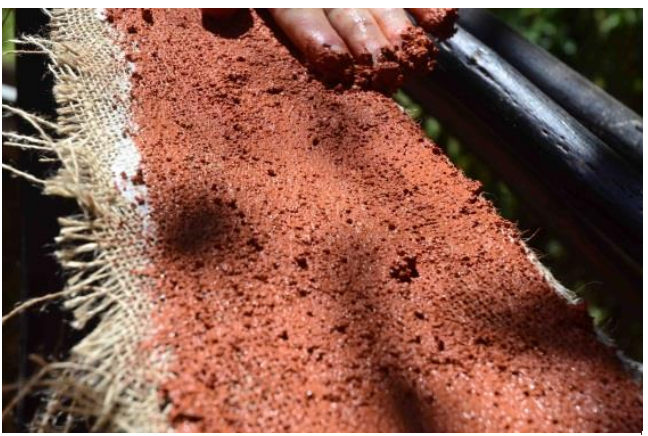

Figura 158- aplicação manual do barro na placa

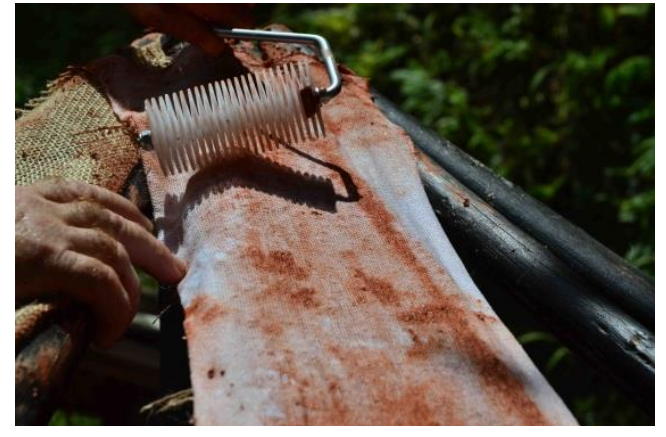

Figura 157 - Rolete sendo usado para fazer a feltragem dos tecidos 
As três camadas seguintes foram feitas com tecido de algodão pressionado sobre a camada anterior. Para facilitar a tarefa de ancoragem foi utilizado um rolete de artesanato para ajudar a pressionar os tecidos (Figura 159). Os dedos também foram usados com o objetivo de ter mais controle pontual para pressionar o compósito. O barro era colocado então nas regiões onde o barro da camada anterior não havia transpassado o tecido.

A camada de cobertura do teto externo deste módulo foi feita com resina de mamona monocomponente (Figura 160). A aplicação foi feita com um pincel e, mais uma vez, foi possível notar a granulometria do barro utilizado interferindo. Pequenas pedras dificultaram um pouco a homogeneização das duas camadas de resina que foi aplicada. Na parte de baixo, o barro excedente do tecido foi espalhado para tornar este lado da placa homogêneo.

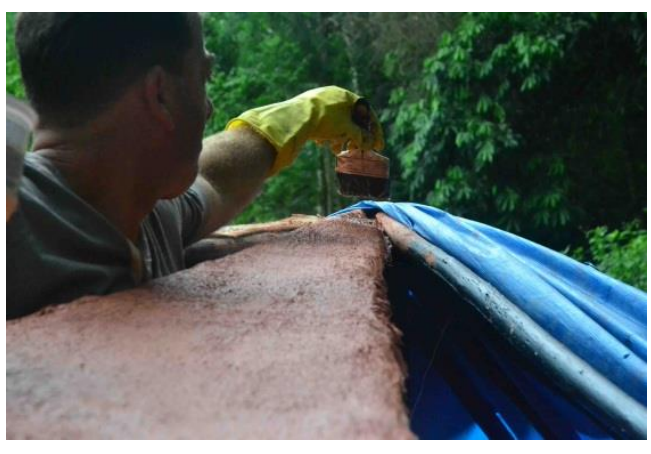

Figura 160 - Pincel com resina de mamona na parte externa do telhado.

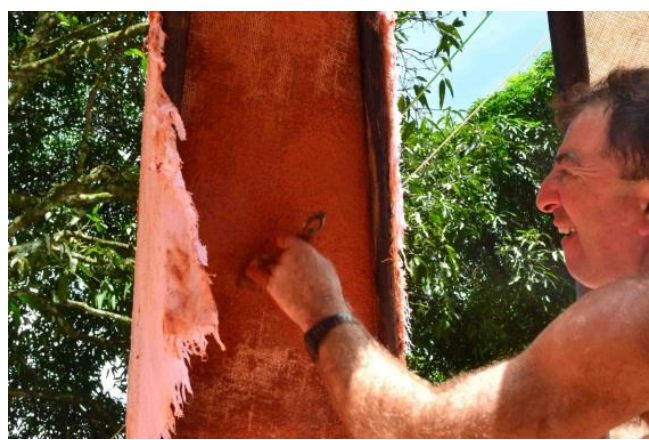

Figura 159 - Pincel com barro para homogeneizar a superfície interna do telhado

Após cerca de 10 dias da experimentação, o experimento foi descoberto para que uma avaliação fosse feita. Próximo ao ponto de maior abertura entre caibros formou-se uma "barriga" similar ao observado no experimento do parabolóide. Excetuando por esta região, as demais não pareceram formar algo do gênero indicando que pode ser o distanciamento entre o tecido que tenha facilitado o surgimento do bolsão.

Também foi feito um teste sobre película de resina de mamona. procedimento foi derramar 6 litros de água sobre o a parte mais alta do módulo e observar o que aconteceria (Figura 162). Como é possível perceber nas figuras (162 e 163), a maior parte da água escorreu sobre a superfície sem problemas. Contudo, observando na parte inferior, a que não recebeu qualquer tratamento além de uma película de barro, surgiram algumas manchas (Figura 163) indicando alguma passagem de água. Isto pode ter ocorrido por uma má aplicação da resina ou alguma partícula de pedra ou areia que foi removida no 
processo de produção da película de resina deixando aquela parte desprotegida. De qualquer forma o fato da película ter sido aplicada apenas de um lado ajudou a sinalizar os pontos onde ainda desprotegidos.

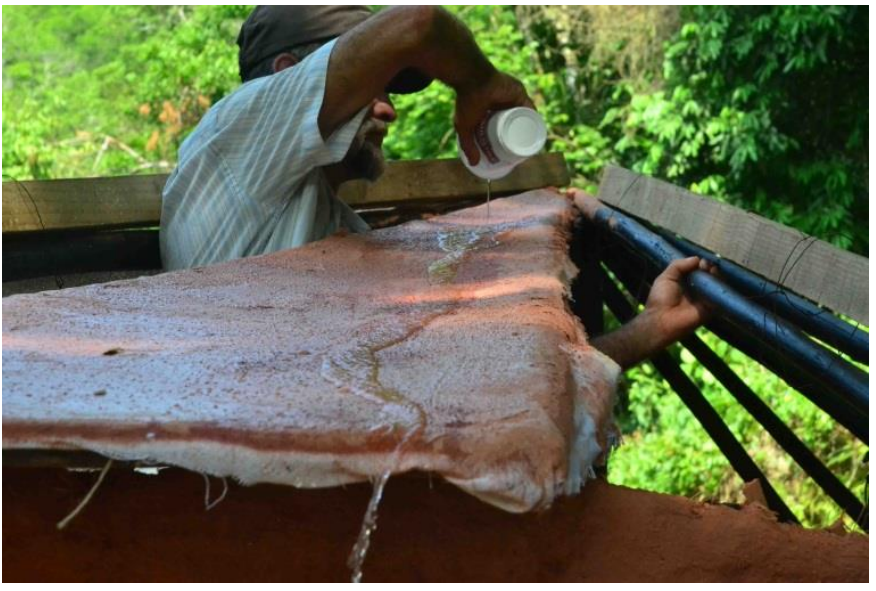

Figura 162 - Água aparentemente escorrendo na superfície.

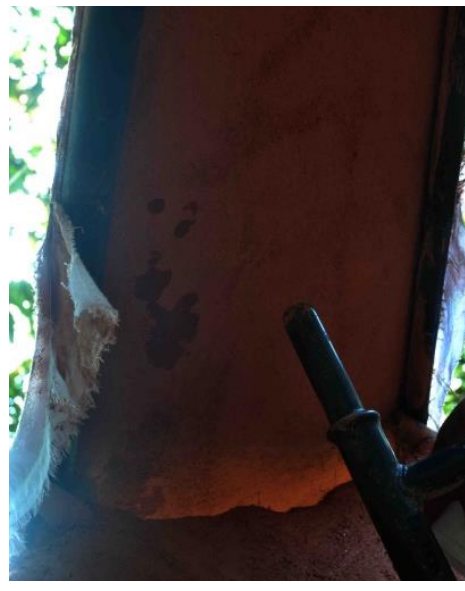

Figura 161 - Manchas escuras na parte inferior sinalizando a passagem de água pela camada de resina

Também ficou claro que trabalhar diretamente no local ficaria cada vez mais difícil à medida que o telhado fosse ficando pronto. Outras questões observadas foram os bolsões formados. Para evitar estas questões, no experimento seguinte construiu-se um molde de madeira que seria pregado sobre os caibros. Esta moldura foi feita pela equipe de funcionários da Fazenda e, a segunda etapa, por duas crianças, um adolescente e três adultos que estiveram na Fazenda durante as férias de escolares janeiro de 2013.

A oficina começou pregando o tecido de juta sobre o molde. O desafio do experimento nessa etapa foi de esticar a lona tensionada o suficiente para que não formasse barriga no molde. Outro desafio foi fixar o tecido na estrutura. Isto porque o grampeador utilizado não possuía grampos profundos. A mão do aplicador deveria que estar firme para que os grampos pudessem penetrar mais verticalmente. Mesmo assim foi necessário usar um martelo para ajudar a fixar o tecido à estrutura (Figura 164). 


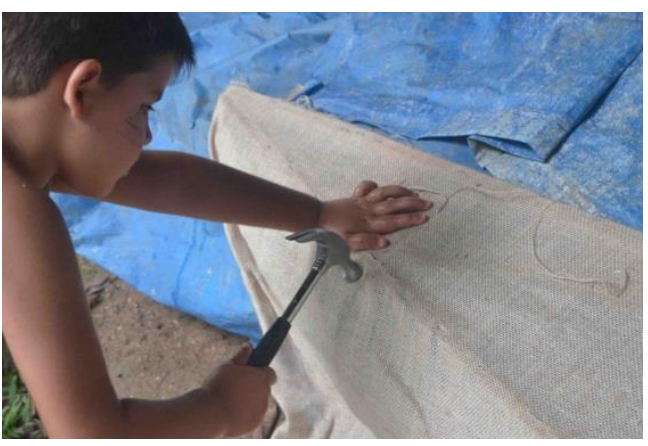

Figura 164 - Criança fixando a tela no molde usando martelo

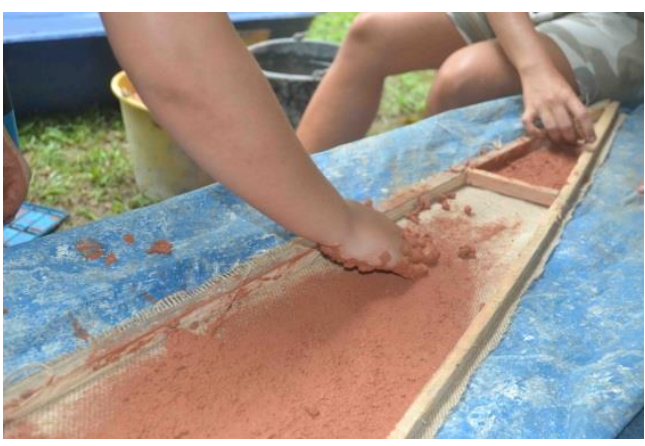

Figura 163 - aplicação do barro na tela sobre superfície

Após a estabilização do tecido na estrutura, a apoiamos sobre uma superfície lisa com a parte do tecido voltada para baixo sobre uma lona de polipropileno. A intenção era dar mais estabilidade para que as camadas de tecido ficassem mais unidas durante o processo de laminação. Utilizando as mãos, principalmente a parte inferior da palma, o barro foi pressionado ao tecido. A estabilidade do piso ajudou aumentou a confiança para pressionar o barro na formação do compósito (Figura 164).

Ao final do experimento, o lado externo foi pouco afetado pela impregnação do barro (Figuras 165 e 166). Foi inferido que antes de aplicar mais uma camada de tecido era importante homogeneizar o lado externo.

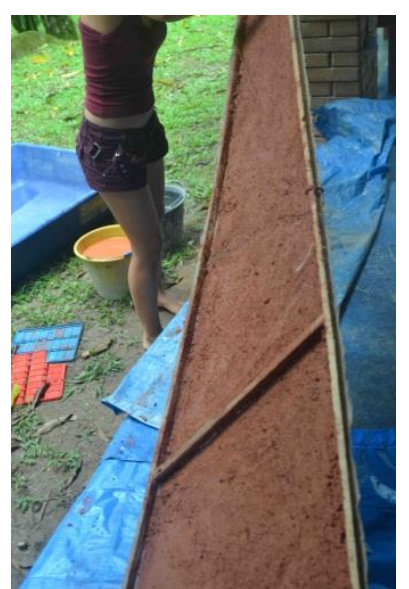

Figura 165 - Parte interna ficou bem visível a aplicação do barro.

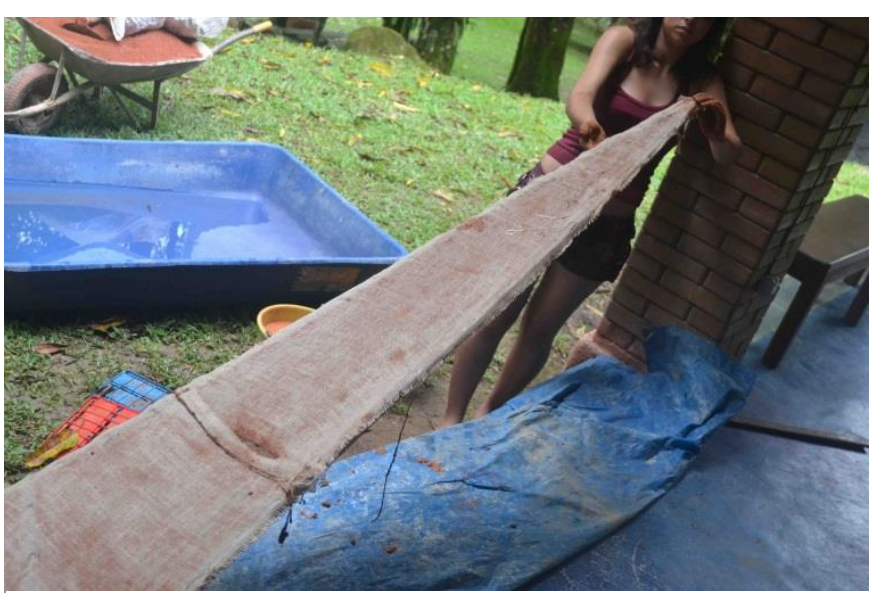

Figura 166 - Os dois lados da tela. No lado externo houve pouca passagem de barro da camada inferior

Devido ao tempo de entrega desta dissertação não foi possível continuar os experimentos. Contudo, foi possível perceber que o tecido que constitui a camada externa deveria ser contínua para facilitar fluidez e a produção da camada de superfície que protegerá o tecido. 


\subsubsection{Espiral treliça}

Os experimentos anteriores em fibrobarro desenvolveram confiança e repertório técnico para construir uma treliça feita a partir de bambus tuldóides. Esta treliça, armada em forma de espiral, foi construída para a instalação de um banheiro próximo à área de refeições. A estrutura foi apoiada sobre pedras e pilares de concreto, como foi mencionado anteriormente ao descrevermos a construção do Icosaedro (Também é possível visualizar na Figura167).
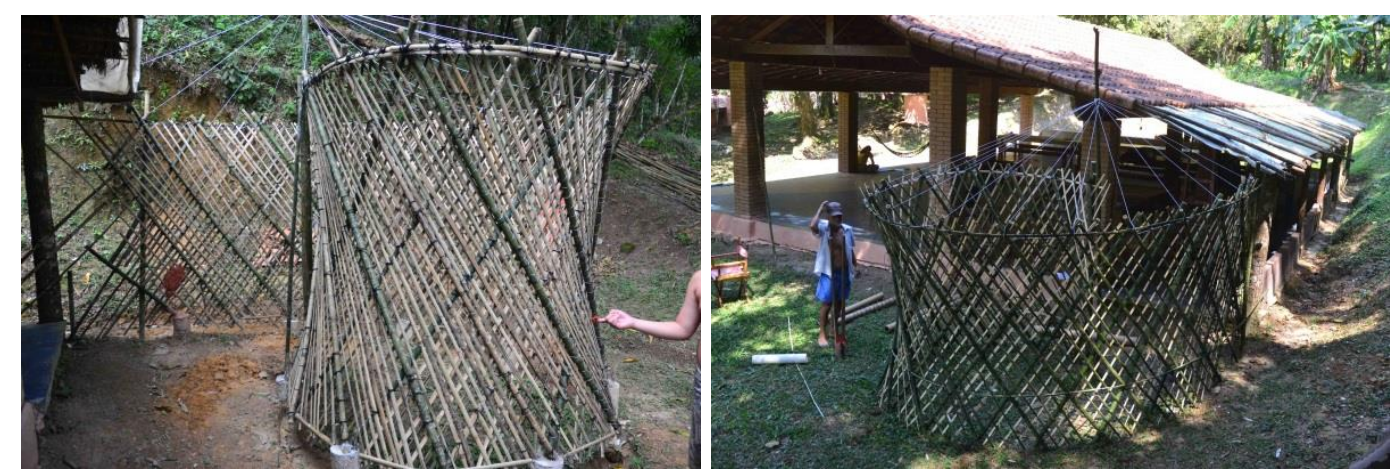

Figura 167 - Duas vistas da treliça montada em forma de espiral

Após a armação da treliça com espaçamento de $50 \mathrm{~cm}$ entre os bambus, foram acrescentadas, por meio de amarração, ripas de bambu para diminuir o espaçamento. A experiência com o Icosaedro barreado estimulou a diminuir ainda mais o espaçamento. Ao final a distância entre bambus ficou entre 3 e 5 cm (Figura 167).

A estrutura ficou extremamente estável e o espaçamento facilitou muito a colocação do barro. Um exemplo de como a tarefa foi facilitada aconteceu quando um grupo de crianças entre 8 a 12 anos de uma escola de classe média da llha do Governador, visitou a Fazenda Faraó para uma vivência.

Durante a oficina, alguns alunos ficaram preparando a argila enquanto outros a misturavam com as fibras para a formação do compósito. Algumas meninas do grupo se responsabilizaram por transformar a massa em compósitos finos e transportá-los até a estrutura.

A estrutura de bambus e a sua forma, tornou a aplicação do compósito muito mais fácil que as anteriores. A estabilidade tornou possível para crianças produzirem e aplicarem placas de $40 \times 60 \mathrm{~cm}$. A atividade tornou-se uma verdadeira brincadeira e as crianças ficaram entusiasmadas por participarem da construção (Figura 168). 
A facilidade que elas encontraram para aplicar foi tamanha e que a descontração foi grande. Mesmo quando o compósito ficou com mais água do que normalmente era utilizado a estrutura aceitou muito bem. Em algumas mantas era perceptível que em outras estruturas o compósito provavelmente iria se desmanchar, mas isso não aconteceu. Os compósitos mais maleáveis tornou possível promover a cobertura dos bambus do outro lado usando o compósito excedente (Figura 169).

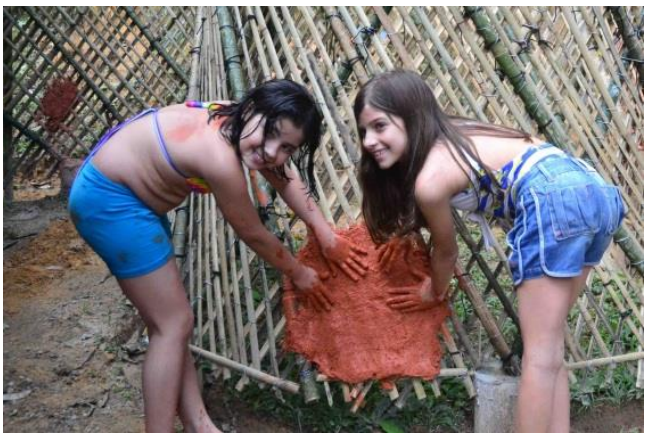

Figura 169 - Crianças de 8 anos aplicando o fibrobarro.

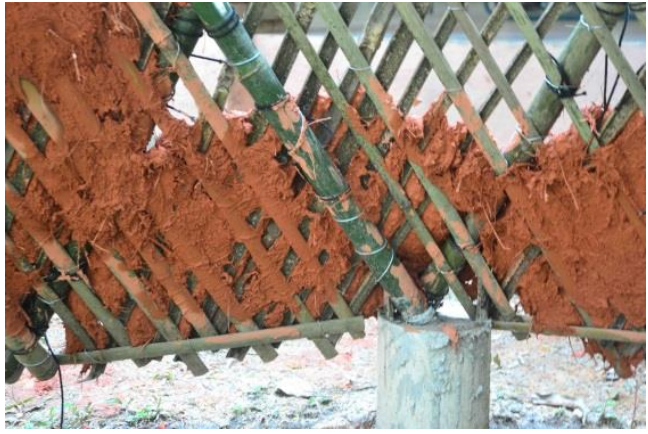

Figura 168 - Compósito do outro lado da aplicação. Detalhe para a treliça apoiada no pilar de concreto que fabricamos.

A estrutura mais fechada e estável tornou a tarefa acessível para crianças fazerem sem muitas dificuldades. Quando a tarefa ficou a cargo dos adultos, funcionários da fazenda, a facilidade foi ainda maior. Em cerca de 4 dias os três funcionários cobriram todos os $24 \mathrm{~m}^{2}$ da estrutura.

Eles relataram que a tarefa ficou bem fácil e rápida. Fazer as paredes com a menor espessura possível também foi mais fácil de executar ao ponto de ser possível visualizar quando os bambus inteiros foram utilizados (Figuras 170 e 1 .

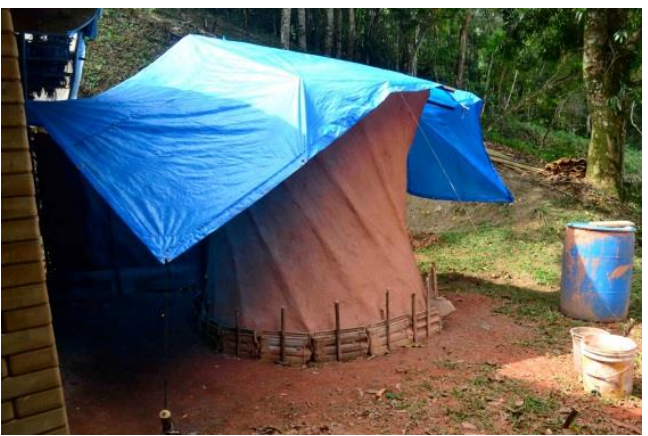

Figura 171 - Parte externa da espiral coberta com lona azul

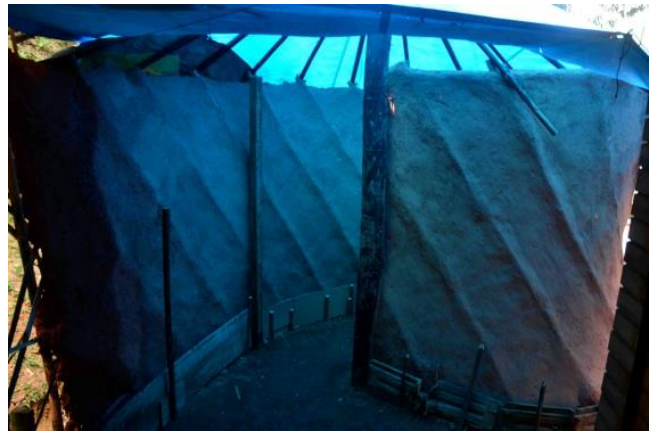

Figura 170 - Parte interna da espiral 
Inicialmente, as paredes foram deixadas sem qualquer acabamento para observação da ação do sol e principalmente da chuva indireta. A observação aconteceu nos períodos mais chuvosos do ano, entre outubro e janeiro de 2013 e neste período, foi possível reparar que a parte inferior da estrutura apresentou pequena lixiviação que poderia ser resolvida com uma camada da chamada "aguada de barro".

Quando a incidência é pontual como um caso de goteira, mais uma vez a lixiviação do barro ocorre, mas, aparentemente este dano é superficial e não interfere na estrutura principal.

Após a observação da ação das intempéries, como película de cobertura, na parte externa foi utilizada cal hidratada misturada com água e terra (razão 1:1:3 de terra:cal:água) (Figura 172).

Para a cobertura, tendo em vista os experimentos de laminação ainda estarem em estágio anterior de domínio da técnica, a estrutura foi coberta com uma lona de polipropileno branca para ajudar na iluminação natural do ambiente. Em junho de 2013, esta construção era amplamente usada na Fazenda Faraó. A forma e os materiais atraem a atenção de curiosos também pelo conforto (Figura 173)

Durante as chuvas, surgem pequenas manchas, provavelmente respingos de quando as gotas batem no chão, na base da estrutura que desapareceram, dependendo do sol e do calor, em um período de 12 a 24 horas (Figura 172),

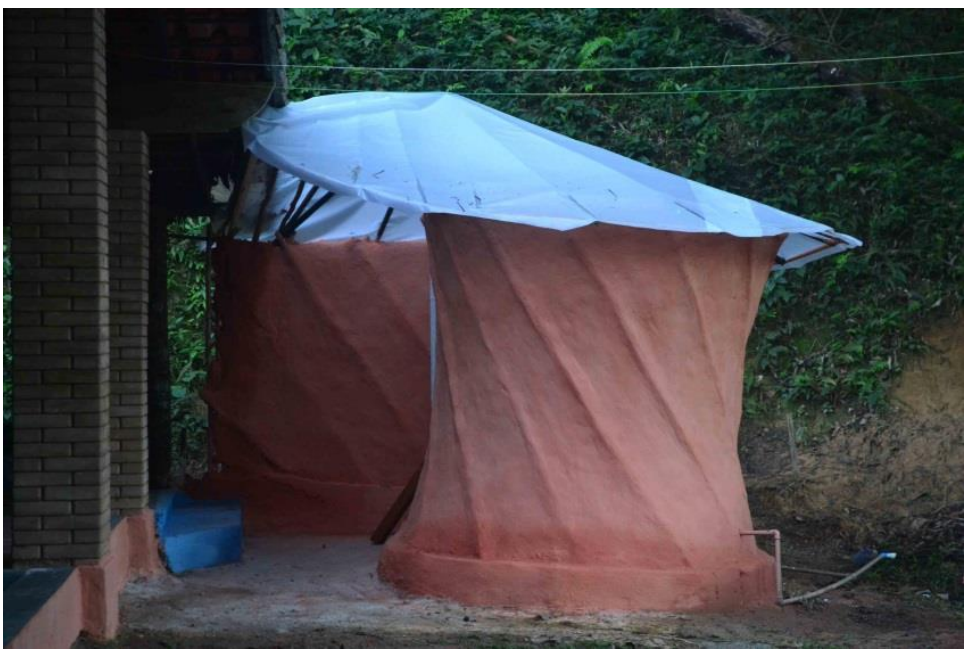

Figura 173 - Parte externa da espiral

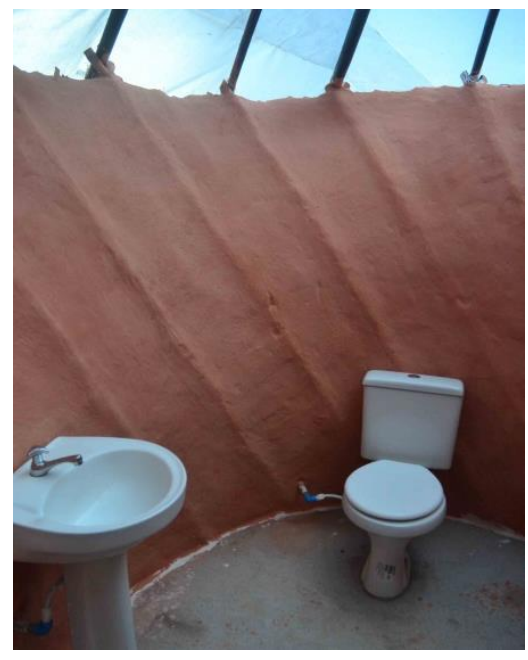

Figura 172 - Parte interna da espiral

${ }^{5}$ Técnica na qual usasse o barro bastante diluído em água. Similar a "aguada de cimento" 
Nesta construção foi possível observar que quando há capricho e cuidado com cada etapa, principalmente nas etapas iniciais, a qualidade do trabalho fica mais fácil de ser obtida e alguns enganos e imprevistos podem ser superados sem muito esforço. A estrutura reforçada com muitas ripas a tornou mais pesada, mas isto pode ser compensado com o aparente menor uso de barro. A estrutura bem armada também facilitou a execução das cascas de cobertura permitindo a ação de mãos menos hábeis. Essa foi uma construção onde toda a comunidade foi capaz de participar com propriedade e entusiasmo.

\subsubsection{Cobertura de pastacal em casa de pau-a-pique}

Durante o segundo semestre de 2011 a equipe de funcionários da Fazenda Faraó fez a primeira construção em terra crua: uma casa de pau-apique. Apesar de já terem visto e convivido com a técnica quando crianças, jamais haviam participado de uma construção do tipo. Os vinte metros quadrados da casa foram feitos justamente para promover o resgate da técnica e preparar o terreno para a implementação de novas possibilidades construtivas mais ousadas, usando materiais tradicionais.

Apesar da técnica possuir mais de 5000 anos, sua origem remonta às savanas africanas ou aos altiplanos da China (Cunha, 2009). A cada nova parede feita, os aprendizados adquiridos eram implementados na construção da parede seguinte. Um exemplo disto foi que, inicialmente, a construção foi feita utilizando barro sem o acréscimo de fibras. Nessa fase foi possível perceber a retração do barro e a importância das fibras para evitar fissuras e rachaduras. Algo que os livros já haviam relatado, mas de aprendizado muito mais perene quando vivido pessoalmente.

Grande parte da casa, principalmente a parte estrutural foi feita pela equipe de funcionários da Fazenda, mas diversos grupos de criança participaram do processo de aplicação do fibrobarro e foi possível perceber a integração e o fascínio destas por poder construir algo que seria usado por elas depois. Huizinga (Huizinga 2008) fala do jogo como parte essencial para a formação da sociedade. Esta Oficina ensinou como a construção deveria ser parte dos processos de aprendizagem em todas as escolas. Como Cunha (Cunha 2009) relatou, antigamente, os processos de aprendizagem tinham origem direta da 
prática no real. As crianças tinham menos responsabilidades, mas eram parte do processo (Figura 174).

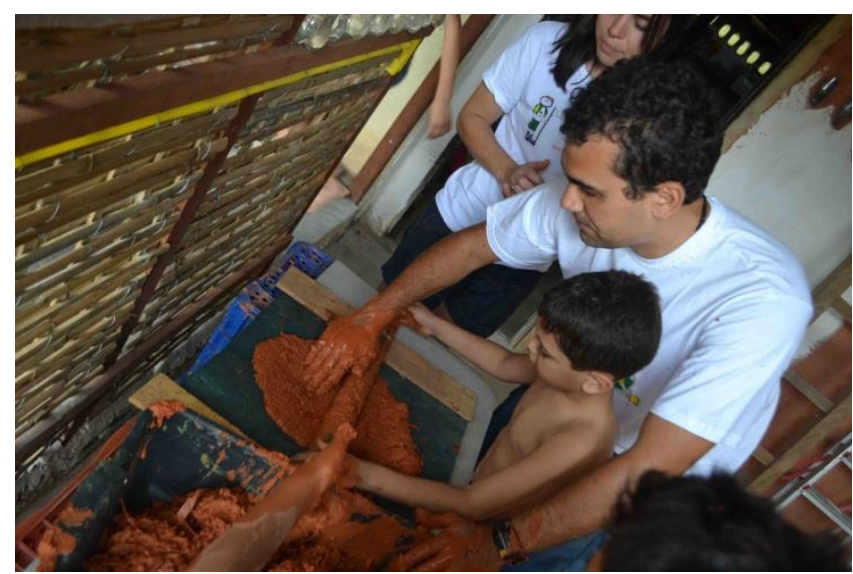

Figura 174 - Construção junto com as crianças ajudou na integração delas com o espaço

Após a construção ter ficado pronta, foi feita uma cobertura das paredes com barro, areia e fibras de uricana para que as paredes ficassem sem rachaduras. Para as camadas seguintes, foram experimentos usando os materiais disponíveis, misturados com a cal hidratada.

Em uma parede exterior fizemos o experimento consistiu em camadas intermediárias misturando cal-barro, barro-esterco e barro-mucilagem de cactos. Cada experimento ocupava um metro quadrado da parede sendo que o restante foi coberto com barro e fibras (Figura 175).

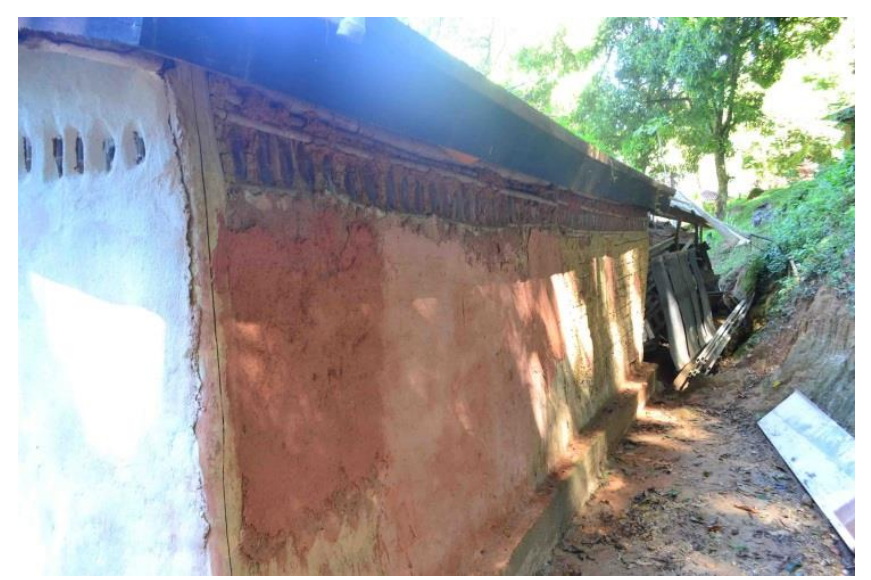

Figura 175 - Cada coloração na parede representa um tipo de acabamento experimentado

Para finalizar, a parede foi coberta com uma película de cal hidratada como se fosse uma tinta bem cremosa. A intenção era observar os efeitos da deterioração da cal hidratada já que havia a crença de que a camada fina iria em 
pouco tempo se deteriorar. Contudo, a experimentação em uma realidade socioambiental surpreendeu (Figura 176).

Excetuando em alguns pontos isolados e nos pontos limítrofes com outros materiais (Figura 177) como as garrafas pet e superfícies de paredes externas de bambu, a "tinta" de cal hidratada ficou exposta à intempéries e não foi alterada. Nos locais onde ocorreram os desprendimentos das camadas de cal foram facilmente restaurados por mais uma película de pastacal.

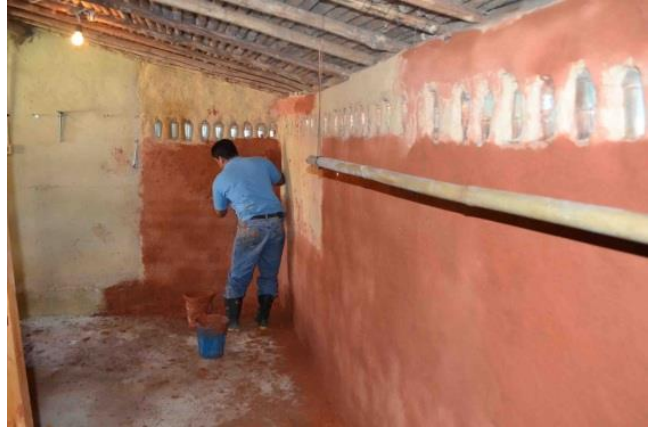

Figura 176 - Pintura de cal das paredes externas e internas. 0 teste que a princípio era só para observar a deterioração durou muito mais do que o esperado.

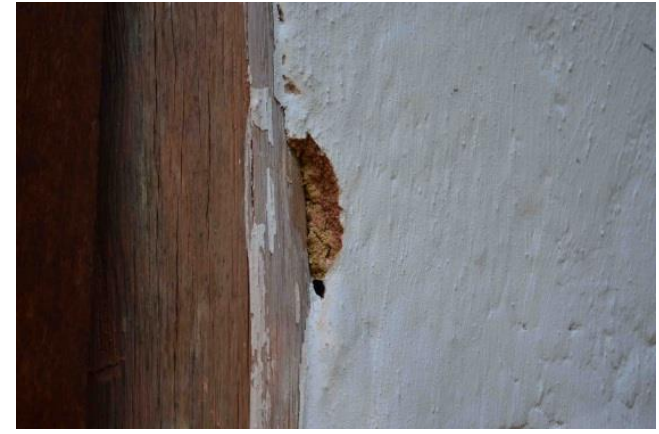

Figura 177 - Detalhe de parte da camada que caiu e foi facilmente reconstituída com nova aplicação.

O telhado, feito usando a técnica de telhado verde, apresentou algumas goteiras. Uma delas incidia justamente sobre parte da parede externa. Observando a mancha formada, a primeira teoria foi de que a goteira havia removido a cal e exposto o barro da parede. Observando mais atentamente, foi possível notar que a camada de cal hidratada ainda estava presente na parede. A mancha de barro observada era proveniente do telhado verde que manchava a parede sem afetar seu revestimento (Figura 178). 


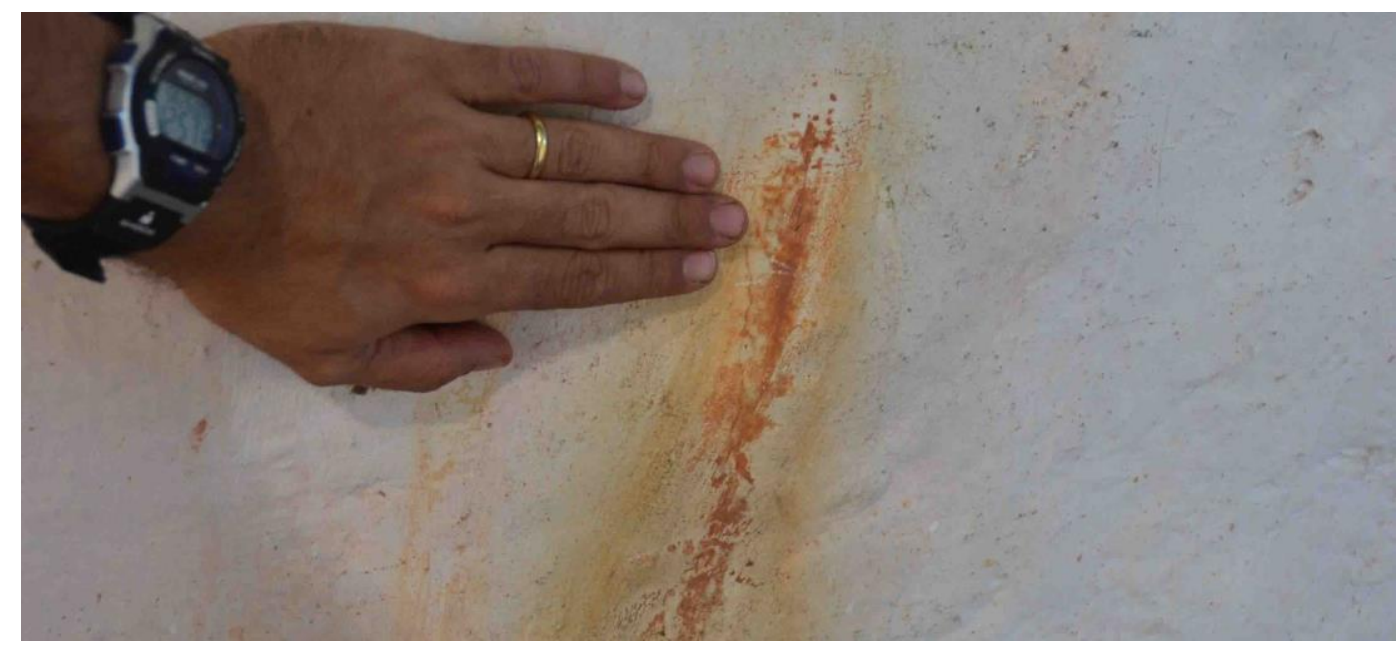

Figura 178 - "Mancha" de terra na verdade veio do telhado verde. Parede ficou intacta apesar da goteira.

Esta experiência vivida na pesquisa de campo colaborou com a teoria de que a cal hidrata, depois do devido tempo de secagem e maturação, pode vir a ser uma opção de revestimento para superfícies mais expostas a intempéries.

Em outra parede, foi feita a experiência de deixar uma parte coberta com uma película de cal hidratada e a outra completamente descoberta. A intenção era visualizar o diferencial da película de cal hidratada em comparação à terra crua exposta, na mesma situação. Após 19 meses de observação a pasta de cal hidratada manteve-se relativamente intacta. Mesmo com o toque, não foi possível notar desprendimento da pastacal. Enquanto isso a parede de barro nos pareceu ter ficado um pouco mais brilhante devido às partículas de quartzo no barro que ficaram mais expostas. Através do toque, era perceptível o desprendimento de partículas de terra sinalizando que ocorria erosão. Apesar disso, estas características só foram perceptíveis por olhares mais atentos e todos os eventuais problemas nos pareciam de fácil restauração considerandose que os materiais estão disponíveis em abundância na região. A manutenção nestes casos torna-se muito mais uma questão de vontade e disponibilidade de tempo.

Um ano e meio após a construção o espaço está sendo plenamente utilizado Figura 179 e 180). Por ter uma forma convencional e, ter uma finalidade específica, esta construção foi mais fácil de ser ocupada e usada. Somente aqueles que estavam presentes na construção percebem que a construção foi feita com barro. A maioria dos outros nota que ela, a casa, tem algumas formas convencionais mas a grande maioria não percebe nada de diferente. Nem mesmo nota-se na temperatura, percebesse a diferença. Até mesmo porque não 
há construção convencional por perto nas mesmas condições para serem comparadas (Figuras 179 e 180).

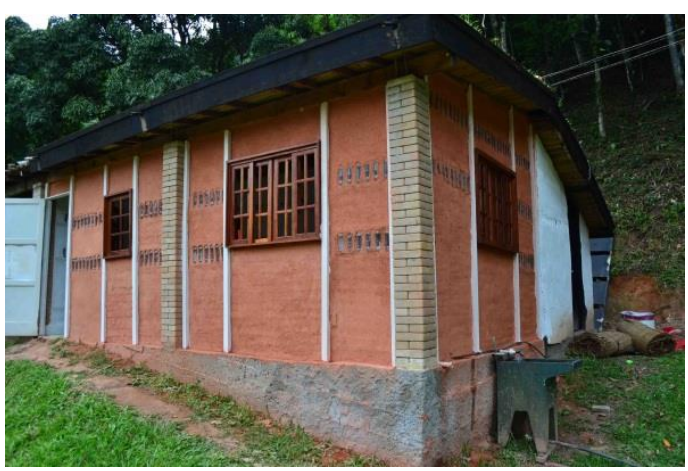

Figura 180 - Visão externa da casa e suas paredes "testando" diferentes tipos de cobertura.

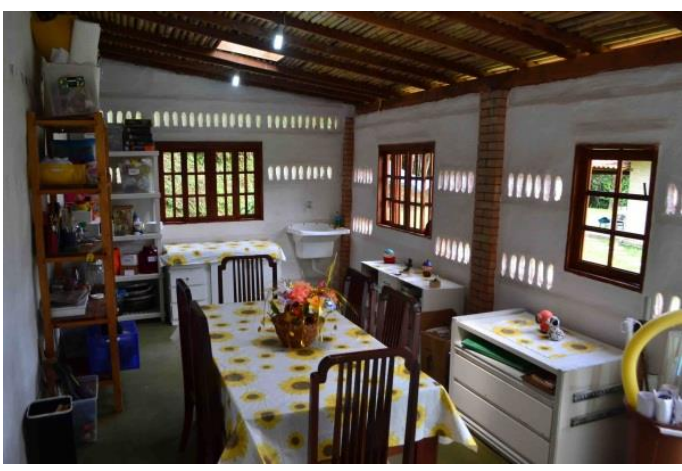

Figura 179 - Casa vista de dentro. Amplamente utilizada e perfeitamente assimilada. 


\section{Principais resultados}

Construções com terra crua fazem parte do repertório técnico da humanidade praticamente desde as primeiras construções na Pérsia, na Índia e etc.. Mesmo assim pode-se inovar com esses materiais. Conceitos de leveza e uso racionalizado são princípios que, adaptados de acordo com as características socioambientais, ainda possuem um amplo repertório.

Ao longo da pesquisa ficou claro que ainda existem possibilidades de estudo das fibras naturais, manufaturadas ou não, para construir de compósitos de fibrobarro. Principalmente quando o fibrobarro não for o principal elemento estruturante da construção, mesmo que essas possibilidades ainda não tenham sido avaliadas em construções longevas, estas análises devem ser vistas construções em funcionamento ou através de testes mais técnicos dentro de laboratórios.

Outro caminho para futuras pesquisas é quando o compósito de fibrobarro for o principal elemento estruturante. $O$ uso de laminados em tecido embebidos com barro ainda não foi experimentado satisfatoriamente fora do ambiente do laboratório. O mesmo vale para compósitos com fibras longas de sisal

A presente pesquisa também não conseguiu abranger as possibilidades de uso para do fibrobarro quando este for composto por mais de um tipo de fibra. A abrangência tanto em relação às espécies compatíveis, quanto à variedade de comprimento das diferentes fibras para que o compósito ficasse mais consistente e resistente aos agentes externos.

Sobre o melhor capeamento para paredes de terra crua, o ditado popular de que a casa de terra crua deve ter um bom "chapéu" (cobertura) e uma boa "bota" (isolamento da umidade vinda do solo) é uma máxima (Easton, 2005 e Guelberth \& Chiras, 2009) que parece extremamente pertinente quando o assunto são construções de terra crua. O fibrobarro requer um pouco mais de cuidado devido à sua pequena espessura o que torna essa máxima ainda mais verdadeira.

Outra possibilidade de estudo é a respeito da armazenagem dos compósitos para serem reutilizados Especialmente em situações de clima úmido como o ocorre no Rio de Janeiro. 
As possibilidades de utilização da cal hidratada ainda podem ser revistas. Principalmente em relação à sua proporcionalidade quando misturada com outros materiais. Também merece atenção a técnica de aplicação da cal hidratada sem que haja a excessiva contração do material. A solução de aplicar em películas foi eficiente, mas ainda é preciso o estudo de mais casos, em diferentes contextos, para assegurar a viabilidade.

Foi averiguado que a pastacal, mesmo quando aplicada em forma de película, consegue, mesmo que provisoriamente, cumprir sua função proteger e dar permeabilidade e resistência à ação da água. Verificar a espessura mínima ou a metodologia para proteger as superfícies de fibrobarro da ação da água é fonte de pesquisa para novos estudos.

Com os experimentos de capeamento em esferas, foi possível afirmar que o revestimento sobre superfícies esféricas é o melhor corpo de prova para o estudo de fissuração.

Os experimentos em laminação indicaram que a feltragem e a ancoragem das fibras entre si e no barro são essenciais para a integração do compósito. Quando esse fenômeno ocorre, o compósito torna-se mais eficiente e durável.

A aplicação da pesquisa com diferentes grupos de sociais forneceu uma grande variedade de observações quanto à metodologia de cobertura de estruturas de bambu utilizando o fibrobarro. O que ficou mais evidente foi necessidade de que cada etapa ser feita com o máximo de atenção e sem pressa para terminar. A experiência mostrou que cada fase do processo é interdependente das demais e nem sempre é possível voltar atrás para recuperar algum ponto que ficou incompleto ou mal feito.

Também ficou claro que cada grupo deve trabalhar com formatos que possam administrar. $\mathrm{O}$ manuseio de mantas excessivamente grande provou-se um equívoco. O aumento gradual do compósito até encontrar o formato mais apropriado é o mais indicado, assim como trabalhar com uma base estável para receber o compósito provou-se ser de suma importância.

As mantas de tecido-barro apresentam uma maior homogeneidade de fibras permitindo a construção de cascas de espessura extremamente finas. Contudo, este tipo de material também encarece o processo de produção por necessitar de maquinário específico para a produção dos tecidos.

A reutilização do fibrobarro armazenado da desconstrução do Túnel expositor para sua aplicação na estrutura do Minhocário do Jardim Anil 
evidenciou que a aplicação e retirada do material pode, e deve ser estudada com mais afinco.

Ao iniciar os estudos desta dissertação foi imaginado que o os materiais seriam o ponto chave para o desenvolvimento de camadas capeamento das construções de terra crua. A partir da prática e das vivências dentro e fora do LILD foi possível perceber o quanto, assim como Boff (Boff 1999) relata, a importância do cuidado, dos gestos e da mente nas ações são muito mais essenciais como meios de pesquisa e obtenção de resultados satisfatórios.

Máquinas robotizadas repetem movimentos pré-programados. O fato da maior parte desta pesquisa ter sido realizada artesanalmente ajudou a perceber os movimentos mecânicos necessários que auxiliam na criação de ferramentas próprias para o trabalho com fibrobarro.

A metodologia de ação no ato de construir deve passar pela consciência e fé dos seus construtores nas suas ações. Estes conceitos são mais essenciais para a realização de um trabalho eficiente e enriquecedor. A técnica apesar do seu importante papel, deve estar servir e ser capaz de ser incorporada ao grupo social que a utiliza. Do contrário, dificilmente será reproduzida e perpetuada pelas gerações seguintes. 


\section{Referências Bibliográficas}

ALLEN, Timothy. Human Planet - Rivers. 20 de Agosto de 2011. 25 de Agosto de 2011. <http://www.youtube.com/watch?v=Es1meqd8SJ0>.

ALVARES, Luciano Rosa Alonso. Cúpula catenária de "Fibrobarro" estruturado com bambu: concepção e processo construtivo. Orientador: José Luis Mendes Ripper. Rio de Janeiro: Dissertação (Mestrado em Artes e Design) - Pontifícia Universididade Católica do Rio de Janeiro, 2008.

ASSOCIAÇÃO CENTRO DA TERRA. Arquitetura de Terra de Portugal. Lisboa: Argumentum, 2005.

BARROS, Luis Vicente Melo. Experimentações convivenciais na aula de bambu. Rio de Janeiro: Pontifícia Universidade Católica do Rio de Janeiro, mimeo.

BECKER, Howard S. Métodos de Pesquisa em Ciências Sociais. 2a edição. São Paulo: Hucitec, 1994.

BOFF, Leonardo. Saber cuidar: Ética do humano - compaixão pela Terra. 7a edição. Petrópolis: Editora Vozes, 1999.

BORDIEU, Pierre. A economia das trocas simbólicas. São Paulo: Perspectiva, 2009.

CAMPOS, Daniel Malaguti. Design de estruturas reticuladas de bambu geradas a partir de superfícies mínimas. Orientador: José Luis Mendes Ripper. Rio de Janeiro: Dissertação (mestrado) Departamento de Artes e Design - Pontifícia Universidade Católica do Rio de Janeiro, 2009.

CAMPOS, Daniel Malaguti. $\mathbf{O}$ aprendizado pela convivência - construções coletivas como instrumento para trocade conhecimentos (título provisório). Rio de Janeiro: Tese (Doutorado) do Departamento de Artes \& Design da Pontifícia Universidade Católica do Rio de Janeiro, mimeo. CORREIA DE MELO, João Victor, et al. "Tenso estrutura reticulada geodésica de bambus amarrados com a forma de uma bolha de sabão." $V$ Simpósio Latinoamericano de tensioestruturas - Tensantiago 2012. Santiago: Pontifícia Universidade Católica do Chile, 2012. 6. 
CÔRTES, Carlos André Lameirão. Construção de casa e pensamento usando terra e bambu: utilizando a pesquisa produção material de um processo construtivo com materiais naturais para fins educacionais. Ed. José Luis Mendes Ripper. Rio de Janeiro: Dissertação (Mestrado em Design) - Pontifícia Universidade Católica do Rio de Janeiro, 1999.

CUNHA, José Celso da. A história das construções, volume 1 - Da pedra lascada às Pirâmides de Dahchur. Belo Horizonte: Autêntica, 2009.

d'ALMEIDA, José Roberto Moraes. "Materiais Compósitos." Rio de Janeiro: Apostila, 2009.

EASTON, David. Como Construir Paredes de Taipa. Junho de 2005. 6 de Janeiro de 2013. <http://www.arq.ufsc.br/arq5661/trabalhos_20051/taipa/manual.htm>.

FATHY, Hassan. Construindo com o Povo: arquitetura para os pobres. Rio de Janeiro: Forense Universitária, 1982.

FLUSSER, Vilém. O mundo codificado: por uma filosofia da comunicação. São Paulo: Cosac Naif, 2007.

FORTY, Adrian. Objetos do desejo. 1a reimpressão. São Paulo: Cosacnaify, 2010.

GIL, Antonio Carlos. Como elaborar projetos de pesquisa. São Paulo: Atlas S.A., 2010.

GUELBERTH, Cedar Rose; CHIRAS, Dan. The Natural Plaster Book. 4a edição. Canada: New Society Plubishers, 2009.

HARVEY, David. Condição pós-moderna. 20a edição. São Paulo: Edições Loyola, 2010.

HUIZINGA, Johan. Homo Ludens: o jogo como elemento da cultura. São Paulo: Perspectiva, 2008.

IFCE-INSTITUTO FEDERAL DO CEARÁ. Plantas Medicinais e fitoterapia. http://www.plantasmedicinaisefitoterapia.com/plantas-medicinaiscolonia.html. s.d. 24 de Dezembro de 2012. $<$ http://www.plantasmedicinaisefitoterapia.com/plantas-medicinaiscolonia.html>.

ILLICH, Ivan. A convivencialidade. Lisboa: Publicações Europa-América, 1976. KAZAZIAN, Thierry. Haverá a idade das coisas leves. 2a edição. São Paulo: Senac São Paulo, 2005.

KHALILI, Nader. Ceramic houses \& earth architecture: how to build your own. California: Call-earth Press, 2005. 
MARANGONI, Gustavo. Las Manos, Lo Barro e La casa. Dir. Gustavo Marangoni. 2000.

LEME, Fernando Betim Paes. Construção com "fibrosolo": um estudo de caso sobre o resgate da técnica de taipa, e seus efeitos no ambiente de clima tropical úmido com estação seca e chuvas de verão. Orientador: José Luis Mendes Ripper. Rio de Janeiro: Dissertação (mestrado) - Pontifícia Universidade Católica do Rio de Janeiro, Departamento de Artes e Design, 2003.

LEME, Fernando Betim Paes. O fibrosolo como pele para a construção: da tradição construtiva do homem do campo, aos espaços habitados pelo homem da cidade. Um conceito de aeração das moradias a partir da aplicação construtiva de cascas, placas e folhas de fibrosolo. Ed. Orientador: José Luis Mandes Ripper. Vols. co-orientador: Alfredo Jefferson de Oliveira . Rio de Janeiro: Tese (doutorado) departamento de Artes \& Design - Pontifícia Universidade Católica do Rio de Janeiro, 2008.

LENGEN, Johan Van. Manual do Arquiteto Descalço. Porto Alegre: Livraria do Arquiteto, 2004.

MANZINI, Ezio; VELOZZI, Carlo. O desenvolvimento de produtos sustentáveis. São Paulo: Edusp, 2002.

MATURANA, Humberto R.; VARELA, F.J.G.. A Árvore do Conhecimento. São Paulo: Palas Athena, 2004.

MENDES, Chico; VERÍSSIMO, Chico; BITTAR, William. Arquitetura no Brasilde Cabral a Dom João VI. Rio de Janeiro: Imperial Novo Milênio, 2010.

MINKE, Gernot. Building with earth: design and technologyof a susteinable architecture. Berlim: Birkhäuser, 2009.

MINKE, Gernot. Manual de construccion em tierra: la tierra como material de construcción y sus aplicaciones em la arquitectura actual. Montevidéu: Nordan comunidad, 1999.

MOLLISON, Bill. Permaculture: a designes' manual. 2a edição. Tasmania Australia: Tagari Publication, 2002.

PaDIL. Bamboo Longhorn beetle. Maio de 2005. 06 de 01 de 2013. <http://www.padil.gov.au/pests-and-diseases/Pest/Main/135592>.

PEDROTTI, Walter. II grande libro della Bioedilizia: dal progetto alla realizzazione. 6a edição. Florença, Itália: Demetria, 2006. 
RASCUSIN, Jacob Deva \& McARLETON, Ace. The Natural Building

Companion: a comprehensive guide to integrative design and construction. Vermont: Chelsea Green, 2012.

RIPPER, José Luis Mendes; LAZARONI, Marcio Amorim; SOUZA, Tiago de Paula. "A utilização do fibrobarro em uma construção efêmera." IV Congresso de Arquitetura e Construção com Terra no Brasil - Terra Brasil 2012. Fortaleza - Ceará: Terra Brasil, 2012. 11.

SANTOS, Milton. A Natureza do Espaço: técnica e tempo, razão e emoção. São Paulo: Editora da Universidade de São Paulo, 2010.

SCHUMACHER, E.F. Small is beautiful: economics as if people mattered. New York: Haper \& Row, publishers, 1973.

SEIXAS, Mario Augusto. Inserção social de arquitetura temporárias de bambus e lonas têxteis utilizando tecnologias não-convencionais. Orientador: José Luis Mendes Ripper. Rio de Janeiro: Dissertação (Mestrado). Departamento de Artes \& Design. Pontifícia Universidade Católica do Rio de Janeiro, 2009.

SILVA, Julia Teles da. A busca de uma técnica qie aproveite os materiais locais na construçao do muro do Laboratório de Investigação em Living Design (LILD) . Orientador: José Luis Mendes Ripper. Rio de Janeiro: Dissertação (Mestrado). Departamento de Artes \& Design da Pontifícia Universidade Católica do Rio de Janeiro , 2011.

SNELL, Clark; CALLAHAN, Tim. Building Green: a complete how-to guide to alternative building methods. 2a edição. Nova York: Lark Books, 2009.

SOARES, Andre. Soluções Sustentáveis: Construção Natural. Pirinópolis: IPEC, 2001.

WEISMANN, Adam; BRYCE, Katy. Using Natural Finishes. Lime- \& earthbased plasters, renders \& paints: A step-by-step guide. Devon: Green Books, 2011.

WOFF, Janet. A produção social da arte. Rio de Janeiro: Zahar, 1982.

XAVIER, Leonardo Menezes. Taipa de sopapo: anacronismo ou instrumento de sustentabilidade na mata atlântica ?. José Luis M. Ripper. Rio de Janeiro: Tese (Doutorado)- Pontifícia Universidade Católica do Rio de Janeiro, Departamento de Artes e Design, 2009.

YAMAKI, Roberto Takao. O Uso da Miniatura no Desenvolvimento e Passagem das Formas Técnicas: Subjetividade e Materialidade. José Luiz Mendes Ripper. Rio de Janeiro: Dissertação de Mestrado. Pontifícia Universidade Católica do rio de Janeiro, 2012. 